UNIVERSIDADE DE SÃO PAULO

INSTITUTO DE GEOCIÊNCIAS

\title{
INVESTIGAÇÃO DE AQUÍFERO FRATURADO PARA ENTENDIMENTO DE FLUXO E TRANSPORTE DE CONTAMINANTES CLORADOS: ESTUDO DE CASO EM VALINHOS, SP
}

\author{
Aline Campello Fanti \\ Orientador: Prof. Dr. Reginaldo Antonio Bertolo
}

\section{DISSERTAÇÃO DE MESTRADO}

Programa de Pós-Graduação em Recursos Minerais e Hidrogeologia

\author{
Versão Corrigida \\ SÃO PAULO \\ 2015
}


Ficha catalográfica preparada pelo Serviço de Biblioteca e Documentação do Instituto de Geociências da Universidade de São Paulo

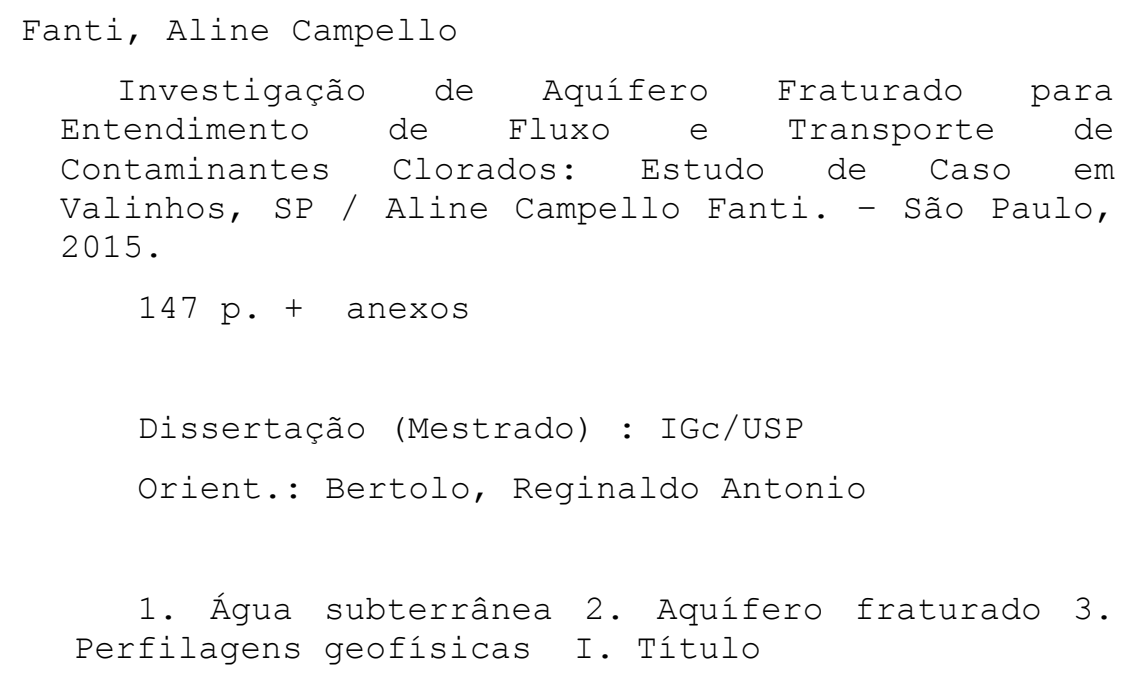




\section{AGRADECIMENTOS}

Um grande ciclo chega ao fim, e só tenho a agradecer por todo o aprendizado durante esse tempo e pelas pessoas que conheci neste caminho.

Agradeço aos meus pais, Ermínia e Onivaldo, por serem meu maior exemplo de dedicação profissional e por sempre apoiarem minhas escolhas e decisões e à minha irmã Gabi, por alegrar a minha vida.

Ao Rodolfo, por compreender meus momentos de ansiedade e por poder compartilhar os momentos de alegria e conquistas. Pela sua ajuda e carinho durante as muitas noites de pesquisa e dedicação ao mestrado.

Ao meu orientador, Reginaldo Bertolo, pelo aprendizado, apoio e correções durante o desenvolvimento dos trabalhos, e principalmente pela sua amizade, confiança, sinceridade e tranquilidade.

Agradeço imensamente a todos os amigos da Waterloo Brasil, em especial à Ana Paula, que desde o início me apoiou e ajudou a tornar possível mais essa etapa, e à Fabiana Cagnon, pelas conversas e constante apoio durante o projeto.

À Fabiana Vogado, querida amiga e parceira dos trabalhos de campo, que me auxiliou no planejamento das etapas e discussão dos dados, e que foi essencial para o desenvolvimento deste trabalho.

Agradeço aos meus amigos e parceiros do Instituto de Geociências e do Laboratório de Modelos Físicos (LAMO) que sempre me auxiliaram nas mais diversas necessidades, em especial à Daphne Pino, Marcos Barbosa e Bruna Fiume. 



\section{RESUMO}

FANTI, A. C. 2015. Investigação de Aquífero Fraturado para Entendimento de Fluxo e Transporte de Contaminantes Clorados: Estudo de Caso em Valinhos, SP. Dissertação (Mestrado), Instituto de Geociências, Universidade de São Paulo, São Paulo, $147 \mathrm{p}$.

Casos de contaminação de aquíferos fraturados são bastante complexos, tendo em vista a heterogeneidade das redes de fraturas, e no geral, sua investigação demanda a utilização de técnicas pouco usuais, como por exemplo o imageamento acústico e a perfilagem de velocidade de fluxo de água. $\mathrm{Na}$ área de estudo, localizada em Valinhos/SP, o uso inadequado de solventes organoclorados no passado ocasionou a contaminação do aquífero raso em duas áreas, e o aparecimento de concentrações no aquifero profundo levaram a condução do atual trabalho, que teve como principal objetivo a elaboração de um modelo conceitual de fluxo de água e transporte de contaminantes no aquífero cristalino. Previamente à investigação do aquífero fraturado, foi realizada uma análise de trabalhos existentes, incluindo a interpretação de lineamentos, levantamentos geológicos além de perfilagens geofísicas de superfície. Em cada área investigada, foi realizada a perfuração de um poço profundo e aplicadas as técnicas de perfilagens de raios gama, cáliper, flowmeter, imageamento acústico, além da filmagem do poço e realização de ensaios hidráulicos nos dois pontos perfurados. Para caracterização química do aquífero fraturado, foram realizadas coletas de água subterrânea em intervalos selecionados com a utilização de obturadores pneumáticos. As cargas hidráulicas medidas durante a amostragem também auxiliaram no entendimento da direção do fluxo de água. O aquífero cristalino é formado por rochas gnáissicas e se encontra bastante fraturado e intemperizado, principalmente na porção superficial da rocha (até aproximadamente $65,0 \mathrm{~m}$ ) onde as maiores velocidades de fluxo de água também foram observadas. A rocha sã possui uma menor densidade de fraturas e predominância de minerais mais claros. As fraturas de baixo a médio angulo de mergulho (Grupo 1) são as mais frequentes em ambas as perfurações e possuem direção principal N-S a NE-SW. São observadas, no geral, exercendo grande influência sobre o fluxo de água, principalmente na porção alterada do gnaisse. Fraturas com ângulo elevado de mergulho, classificadas como Grupo 2 (paralelas à foliação) e Grupo 3 (direção NW à W), são também observadas ao longo de toda a perfuração estabelecendo a conexão hidráulica entre as fraturas do Grupo 1. Em menor proporção, são ainda verificadas fraturas com ângulos de mergulho $>40^{\circ}$ pertencente aos Grupos 4 (NE-SW), 5 (E-W), 6 (NW-SE) e 7 (E-W). O fluxo de água subterrânea se mostrou descendente na porção superior da rocha alterada e ascendente na porção mais profunda, possivelmente direcionando a água subterrânea para a região de transição da rocha mais alterada para a rocha sã (entre 61 a $65 \mathrm{~m}$ de profundidade). Apesar do fluxo ascendente em profundidade, o bombeamento de poços tubulares existentes no entorno ao longo dos anos, favoreceu a migração dos contaminantes para porções mais profundas. Os contaminantes observados no poço tubular P6 possuem maior semelhança com os contaminantes observados na Área 2, e ambos estão localizados entre lineamentos NW-SE, indicando uma possível influência dos lineamentos no controle sobre o fluxo de água. No entanto, para entendimento do transporte dos contaminantes em área, é necessário um adensamento da rede de monitoramento, levando em consideração a heterogeneidade do meio e as incertezas relacionadas à extrapolação dos dados para áreas não investigadas.

Palavras-Chave: água subterrânea, aquífero fraturado, perfilagens geofísicas 


\begin{abstract}
Cases of contamination in fracture aquifers are complex, given the heterogeneity of the fractures network and the common requirement of unusual techniques for investigation, such as the acoustic imaging and water flow velocity profile. In the study area, located in Valinhos / SP, the inappropriate use of organochlorine solvents in the past caused the contamination of the shallow aquifer in two areas, and the appearance of concentrations in the deep aquifer, lead to the current work, whose main goal was the development of a conceptual model of groundwater flow and contaminants transport in the crystalline aquifer. An analysis of pre-existing works, including the interpretation of lineaments, geological surveys as well as surface geophysical profiling, was conducted previously the investigation of fractured aquifer. A deep well was drilled in each area and applied the profiling methods gamma ray, caliper, flowmeter and acoustic imaging, as well as filming the wells and conducting hydraulic tests in two drillings. For chemical characterization of the fractured aquifer, groundwater sampling were collected at selected intervals with the use of pneumatic packers. Hydraulic heads measured during sampling also helped in understanding the direction of water flow. The crystalline aquifer is consisted by a fractured and weathered gneissic rock, especially in the upper portion of the rock (up to approximately $65.0 \mathrm{~m}$ ) where higher water flow rates were observed. The fresh rock has a lower fracture density and predominantly lighter minerals.

Fractures of low to medium dip angle (Group 1) are the most frequent in both boreholes. Their main direction is N-S to NE-SW, and they are in general, exerting great influence on the water flow, especially in the weathered portion of the gneiss. Fractures with high dip angle classified as Group 2 (parallel to foliation) and Group 3 (direction NW to $\mathrm{W}$ ) are also observed throughout the drillings, establishing the hydraulic connection between the fractures from Group 1. At a lower frequency, fractures with dip angles $>40^{\circ}$, classified as groups 4 (direction NE-SW), 5 (E-W), 6 (NW-SE) and 7 (E-W), are verified. The water flow was downgradient in the surficial weathered portion of the rock, and upgradient in the deepest portion, probably directing the water flow to the transition portion of altered rock for the fresh rock (between 61 to $65 \mathrm{~m}$ in depth). Despite the upward flow in higher depth, pumping existing wells in the vicinity over the years favored the migration of contaminants into deeper portions of que aquifer. The compounds observed in the tubular well P6 have a greater resemblance to the contaminants observed in Area 2, and both are located between NW-SE lineaments, indicating a possible influence on control over the water flow and contaminant transport. However, a dense of monitoring network is necessary to understand the transport of contaminants in the study area, for which should be considered the proposed objectives, and taken into account the heterogeneity of the environment and the uncertainties related to extrapolation of data to non-investigated areas.
\end{abstract}

Keywords: ground water, fractured aquifer, geophysical profiling 


\section{ÍNDICE}

1. INTRODUÇÃO

2. OBJETIVOS

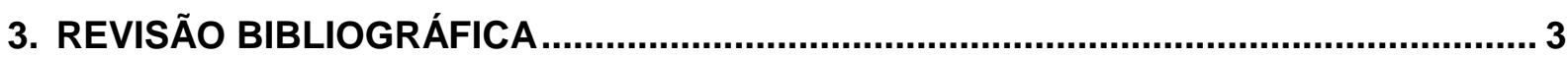

3.1. Características dos Compostos Organoclorados.......................................... 3

3.2. Fluxo de Água e Transporte de Contaminantes em Aquíferos fraturados..... 8

3.3. TÉCNICAS de INVESTIGAÇão em AQuífEROS Fraturados ..................................... 14

3.3.1. Imageamentos e Perfilagens Geofísicas ................................................. 18

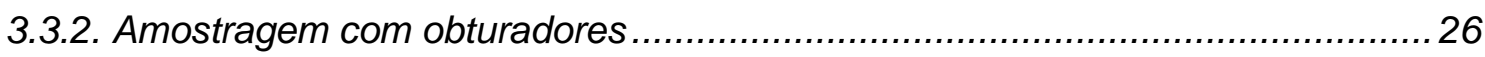

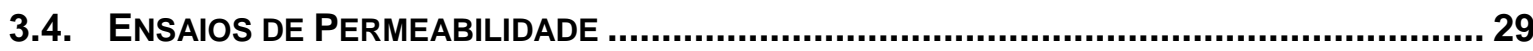

4. CARACTERIZAÇÃO DA ÁREA

4.1. GEOLOGIA REGIONAL E LOCAL....................................................................... 30

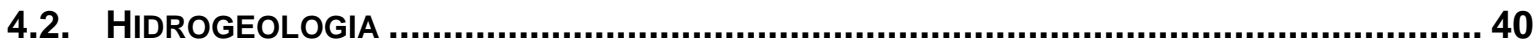

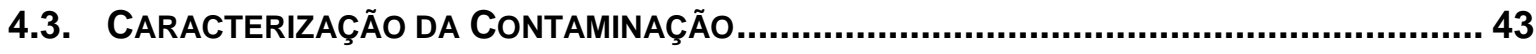

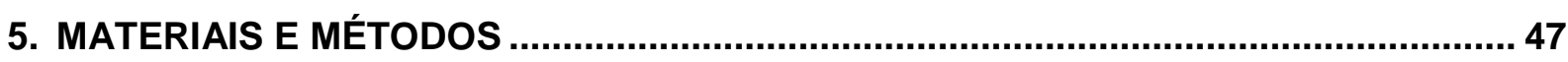

5.1. SONDAGENS PARA INVESTIGAÇÃo do AQUífERO FratURADO...................................47

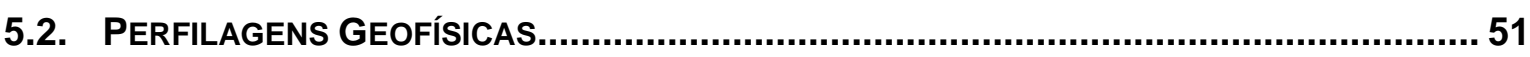

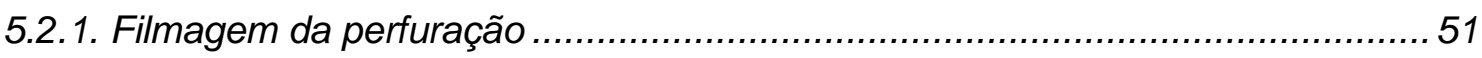

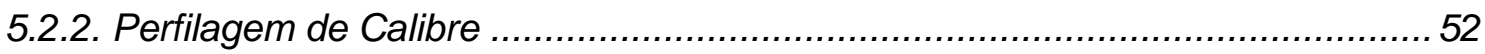

5.2.3. Perfilagem HRAT (High Resolution Acoustic Televiewer) e Raios Gama...........53

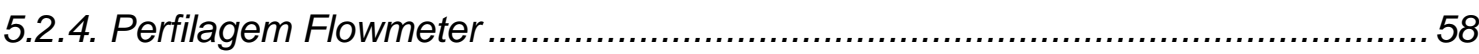

5.3. amostragem do aquífero Cristalino com o emprego de Obturadores

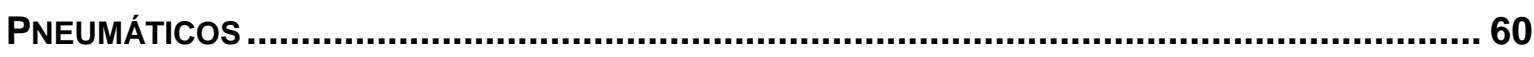

5.4. InStalaÇão dos Poços de Monitoramento no AquífERo Cristalino ...................63

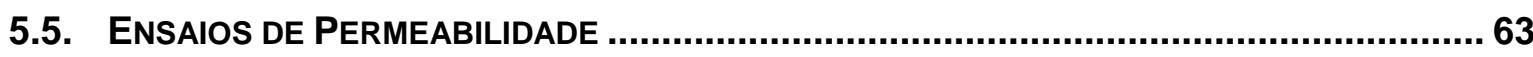

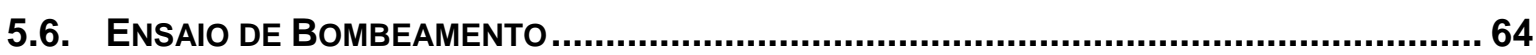

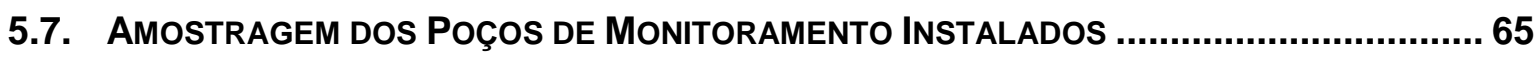

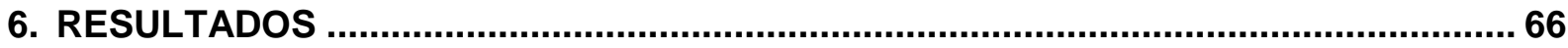

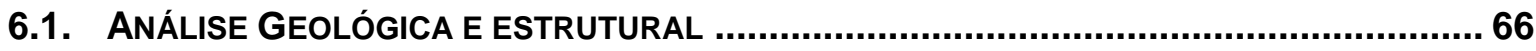

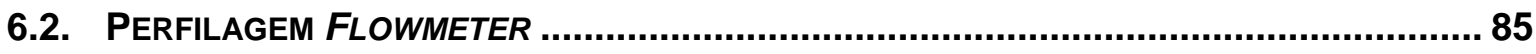

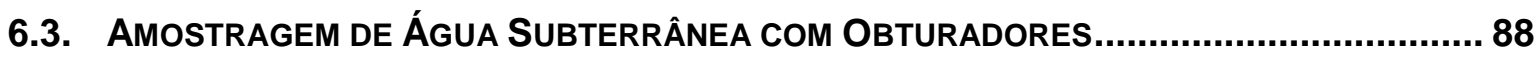

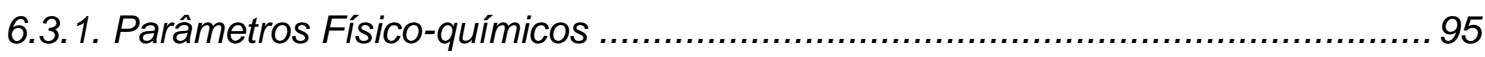

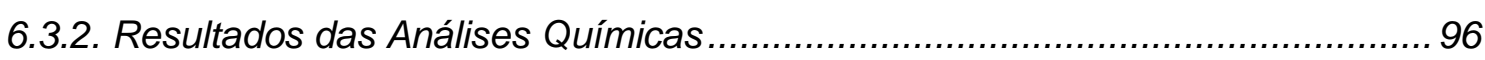

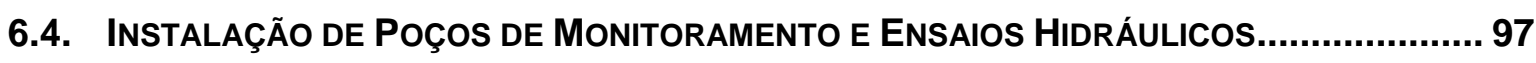

6.4.1. Ensaios de Permeabilidade .................................................................. 99

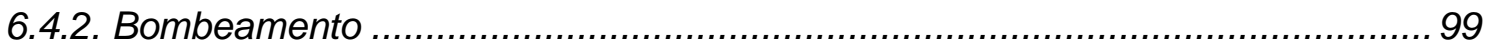

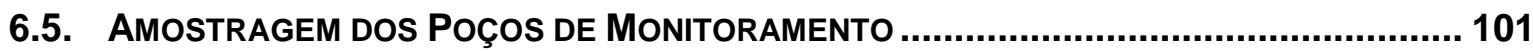




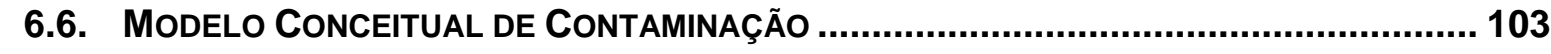

7. CONCLUSÕES E RECOMENDAÇÕES ............................................................. 110

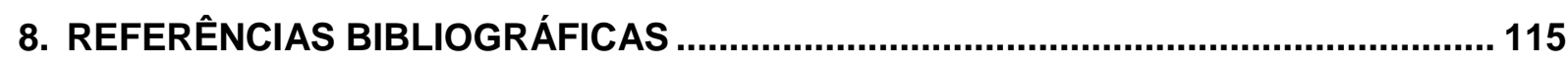

ANEXO 1 - COMPILAÇÃO DAS PERFILAGENS ................................................... 123

ANEXO 2 - FEIÇÕES IDENTIFICADAS PELAS PERFILAGENS .................................. 133

ANEXO 3 - ESPAÇAMENTO DOS GRUPOS DE FRATURAS …................................. 143 


\section{LISTA DE FIGURAS}

Figura 1 - Processos de transformação biótica e abiótica durante a redução de compostos clorados. (Modificado de Wiedemeier et al., 1999) 7

Figura 2 - Modos de propagação de fraturas por extensão perpendicular à superfície da fratura (I) e por cisalhamento perpendicular (II) ou paralelo (III) à frente de propagação da ruptura. Modificado de Lawn \& Wilshaw (1993) 10

Figura 3 - Variação da condutividade hidráulica em função da abertura (b) e da densidade da fratura (Hoek \& Bray, 2005) 12

Figura 4 - Etapas Abordagem DFN (modificada de Parker, 2012). 15

Figura 5 - Arranjo dos equipamentos utilizados para a execução das perfilagens geofísicas (modificado de Hubbard et al.2008; extraído de Ribeiro, 2012)

Figura 6 - (A) Representação plana do imageamento acústico (ATV ou BHTV) de uma feição de fratura que intercepta o poço (modificada de Paillet, 1994). (B) Imagem de amplitude gerada pela fratura (linha mais escura) ...................................................... 23

Figura 7 - Esquema de funcionamento do Flowmeter (Modificada de Hess \& Paillet, 1990)25 Figura 8 - Esquema de amostragem com obturadores (Modificada de Stewart, 2000)........ 27

Figura 9 - Localização da área de estudo ............................................................... 30

Figura 10 - Mapa geológico da área de estudo ......................................................... 32

Figura 11 - Principais feições identificadas na fotointerpretação (Fonte: BASE Aerofotogrametria e Projetos Ltda, 1972) ................................................................... 34

Figura 12 - Mapa com pontos de afloramentos visitados por Waterloo (2011) .................... 35

Figura 13 - Projeções polares dos planos de foliação e de fraturamento nos gnaisses xistosos da unidade migmatítica superior .................................................................... 36

Figura 14 - Rosácea dos dados estruturais dos gnaisses xistosos mostrando as principais direções dos planos de foliação e de fraturamento

Figura 15 - Projeções polares dos planos de foliação e de fraturamento nos gnaisses graníticos da unidade migmatítica intermediária

Figura 16 - Rosácea dos dados estruturais dos gnaisses graníticos mostrando as principais direções dos planos de foliação e de fraturamento

Figura 17 - Mapa de variação de resistividade. Valores elevados de resistividade estão associados à presença da rocha sã em porções mais próximas da superfície do terreno. .. 39 Figura 18 - Mapa potenciométrico do aquífero raso (adaptado de Waterloo, 2011) ...........41

Figura 19 - Seção geológica e nível de água ........................................................... 42

Figura 20 - Mapa de isoconcentração da somatória dos compostos organoclorados no aquífero raso. Abril 2014. (Waterloo, 2011) 
Figura 21 - (A) Tanques de circulação de fluido utilizados no método rotativo; (B) Retorno do material perfurado através do 'cachimbo'

Figura 22 - Brocas utilizadas na etapa de perfuração rotativa. (A) Broca de diâmetro 12.1/4"; (B) Broca de diâmetro 9.7/8"

Figura 23 - (A) Broca de Ø6" de tungstênio utilizada no método rotopneumático; (B) Unidade compressora que alimenta o sistema de martelo e broca no método rotopneumático 50

Figura 24 - (A) Tripé e demais equipamentos utilizados na descida da câmera para dentro da seção perfurada durante a perfilagem ótica; (B) Detalhe das câmeras presentes na sonda

Figura 25 - (A) Esquema da sonda utilizada na perfilagem cáliper (FONTE: Hydrolog. http://www.hydrolog.com.br/portugues/conteudo/index/cáliper-slim); 53

Figura 26 - (A) Exemplo de gráfico gerado na captação da radiação gama. (B) Sonda acústica utilizada.

Figura 27 - Figura esquemática de uma seção vertical de um furo mostrando três orientações diferentes de fraturas, todas com o mesmo espaçamento ortogonal (d). A fraturas em azuis são corretamente amostradas $(n=6)$, as fraturas em verde são subamostradas e as fraturas em vermelho não são interceptadas pela perfuração (Modificado de Task Geoscience, 2008) 56

Figura 28 - Exemplos de diferentes tipos de distribuição das fraturas que podem ser $(A)$ aleatórias, $(B)$ regular, $(C)$ regular variada, ou (D) regular concentrada (PINO, 2012) 58 Figura 29 - (A) Sonda utilizada na perfilagem flowmeter; (B) Detalhe da ponteira da sonda, onde ocorre a emissão do pulso de calor

Figura 30 - Gráfico de inflexão positiva apresentado pelo software de aquisição de dados obtidos com o flowmeter. O ajuste da linha vermelha indica o ponto escolhido em que 0 tempo decorrido será convertido em velocidade de fluxo. 59

Figura 31 - Sistema de obturadores utilizados

Figura 32 - Localização do Poço Tubular P6 utilizado para bombeamento e dos poços de monitoramento de nível de água - Área 1 65

Figura 33 - Perfil litológico dos poços perfurados

Figura 34 - (A) Rocha gnáissica encontrada na perfuração do PP-02; (B) Gnaisse migmatítico representante da Unidade Ortognáissica Migmatítica Intermediária do Complexo Socorro-Guaxupé 68

Figura 35 - Resultado da perfilagem cáliper e gama no ponto PP-01. 69

Figura 36 - Resultado da perfilagem cáliper e gama no ponto PP-02. 70

Figura 37 - Projeções polares dos planos de fraturas presentes no ponto PP-01 e grupos de fraturas identificados (A) sem aplicação da correção de Terzaghi, (B) com correção de Terzaghi. 
Figura 38 - Diagrama de roseta mostrando as principais direções e histograma dos ângulos de mergulhos dos planos de fraturamento no ponto PP-01

Figura 39 - Círculos Máximos dos principais Grupos de Fraturas identificados no PP-01 ... 73 Figura 40 - Estereogramas com contornos de densidade das feições observadas em diferentes profundidades no PP-01

Figura 41 - Projeções polares dos planos de fraturamento presentes no ponto PP-02 (A) sem aplicação da correção de Terzaghi, (B) com correção de Terzaghi

Figura 42 - Diagrama de roseta mostrando as principais direções e histograma dos ângulos de mergulhos dos planos de fraturamento no ponto PP-02

Figura 43 - Círculos Máximos dos principais Grupos de Fraturas identificados no PP-02 ... 78 Figura 44 - Estereogramas com contornos de densidade das feições observadas em diferentes profundidades no PP-02

Figura 45 - Projeções polares dos planos de fraturamento presentes no ponto P5 (a) sem aplicação da correção de Terzaghi, b) com correção de Terzaghi

Figura 46 - Diagrama de roseta mostrando as principais direções e histograma dos ângulos de mergulhos dos planos de fraturamento no ponto P5.

Figura 47 - Círculos Máximos dos principais Grupos de Fraturas identificados no poço tubular P5

Figura 48 - Perfil de variação de velocidade média de fluxo. 86

Figura 49 - Variação dos níveis d'água durante a amostragem do ponto PP-01C 89

Figura 50 - Variação dos níveis d'água durante a amostragem do ponto PP-01B 90

Figura 51 - Variação dos níveis d'água durante a amostragem do ponto PP-01A. 90

Figura 52 - Esquema da conexão entre os principais grupos de fraturas 92

Figura 53 - Variação dos níveis d'água na amostragem do ponto PP-02C. 93

Figura 54 - Variação dos níveis d'água na amostragem do ponto PP-02B. 93

Figura 55 - Variação dos níveis d'água na amostragem do ponto PP-02A. 94

Figura 56 - Perfil litológico e construtivo dos poços instalados 98

Figura 57 - Gráfico de variação de nível de água dos poços de observação medidos durante o bombeamento do P6. 100

Figura 58 - Esquema da conexão entre os aquíferos em regime de bombeamento .......... 101

Figura 59 - Modelo Conceitual da área...... 104

Figura 60 - Seção hidrogeológica da área de estudo e compostos organoclorados identificados. 105

Figura 61 - Nível de água medido durante a amostragem com os obturadores 109 


\section{LISTA DE TABELAS}

Tabela 1 - Principais organoclorados 3

Tabela 2 - Propriedades físicas dos compostos de interesse.

Tabela 3 - Resultados de compostos orgânicos clorados nos poços do aquífero raso nas

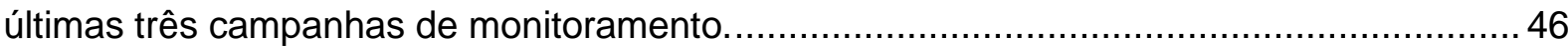

Tabela 4 - Justificativa da locação das sondagens.................................................. 47

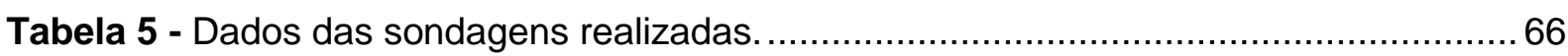

Tabela 6: Quantidade de fraturas corrigidas pela aplicação do método de Terzaghi (1965) para cada grupo de fraturas identificado no ponto PP-01.

Tabela 7 - Tipo de espaçamento, distribuição de densidade e espaçamento médio das fraturas no PP-01 após a aplicação da correção de Terzaghi.

Tabela 8 - Quantidade de fraturas corrigidas pela aplicação do método de Terzaghi (1965) para cada grupo de fraturas identificado no ponto PP-02.

Tabela 9 - Tipo de espaçamento, distribuição de densidade e espaçamento médio das fraturas no PP-02 após a aplicação da correção de Terzaghi.

Tabela 10 - Quantidade de fraturas corrigidas pela aplicação do método de Terzaghi (1965) para cada grupo de fraturas identificado no ponto P5.

Tabela 11 - Tipo de espaçamento, distribuição de densidade e espaçamento médio das fraturas no P5 após a aplicação da correção de Terzaghi.

Tabela 12: Principais variações de vazão nos pontos PP-01 e PP-02 segundo dados do Flowmeter. 88

Tabela 13 - Dados das amostras coletadas no aquífero cristalino. 89

Tabela 14 - Dados Físico-químicos medidos em campo dentro dos obturadores. 95

Tabela 15 - Concentrações de Compostos Orgânicos Voláteis (VOC's) na água subterrânea nos intervalos amostrados com obturadores nos pontos PP-01 e PP-02.

Tabela 16 - Concentrações de Compostos Orgânicos Voláteis (VOC's) na água subterrânea dos poços PP-01 e PP-02. 102

\section{LISTA DE ANEXOS}

Anexo 1 - Compilação das perfilagens

Anexo 2 - Feições Identificadas pelas perfilagens

Anexo 3 - Espaçamento dos grupos de fraturas 


\section{INTRODUÇÃO}

A área de estudo, localizada no município de Valinhos, sudoeste do Estado de São Paulo, desde 2006 é alvo de estudos ambientais conforme preconiza o Manual de Gerenciamento de Áreas Contaminadas (CETESB, 2001). A área de interesse está localizada dentro de uma unidade industrial que utilizava compostos orgânicos clorados para limpeza de equipamentos e peças. Devido às antigas práticas de manipulação inadequada dos solventes organoclorados, estes vieram a contaminar o aquífero raso da área de estudo. Concentrações de tetracloroeteno, tricloroeteno e dos subprodutos de degradação, tais como os isômeros do 1,2 dicloroeteno e cloreto de vinila, foram observados na água subterrânea em concentrações acima dos valores de intervenção (VI) definidos pela CETESB em duas áreas distintas dentro da unidade industrial, denominadas neste trabalhao de Área 1 e Área 2.

Durante os trabalhos ambientais desenvolvidos pela consultoria ambiental Waterloo Brasil, verificou-se que concentrações desses compostos foram observadas em poços tubulares instalados a aproximadamente $100 \mathrm{~m}$ das possíveis áreas fonte, sendo o bombeamento desses poços paralisado.

A área de estudo não possui abastecimento público de água, sendo suprida exclusivamente pelo bombeamento de poços tubulares que extraem água do aquífero cristalino. Desse modo, devido à possibilidade dos contaminantes migrarem do aquífero raso para porções mais profundas do aquífero através de fraturas e falhas existentes nas rochas, houve a necessidade de se compreender a conexão hidráulica entre os diferentes níveis do aquífero e o comportamento dos contaminantes no meio fraturado, especialmente próximo às fontes de contaminação.

O estudo em aquíferos cristalinos no Brasil é recente e está principalmente relacionado à exploração da água subterrânea. A contaminação dos aquíferos rasos e a possibilidade de impacto no aquífero cristalino vêm fazendo aumentar a preocupação dos órgãos reguladores, uma vez que se estima que $39 \%$ do total de água utilizada para abastecimento no Brasil provém da água subterrânea (ANA, 2013). Deste modo vem crescendo a necessidade do desenvolvimento e aprimoramento de técnicas de investigação que possibilitem uma melhor compreensão do fluxo de água e do transporte e comportamento dos contaminantes nesses meios. 
Segundo Parker (2007), o estado de conhecimento referente à contaminação em aquíferos fraturados em 2007 estava onde o conhecimento das plumas de contaminação em meios porosos granulares estava na década de 1950. Estudos detalhados em aquíferos porosos foram realizados a fim de se entender 0 comportamento dos contaminantes desses meios em larga escala. No entanto as dificuldades em meio fraturado são maiores, tendo em vista a diferença na complexidade e heterogeneidade das redes de fraturas, além do elevado custo de perfuração e investigação em profundidade. A investigação da geologia estrutural de detalhe dos condicionantes geológicos que regem a circulação de água nos meios fraturados possibilita um melhor entendimento dos caminhos preferenciais de fluxo, auxiliando na criação de modelos conceituais geológicos da área, otimizando tempo e recursos financeiros (Fernandes, 2008).

Neste contexto, uma investigação de detalhe do aquífero cristalino próximo às principais fontes de contaminação foi realizada na área de estudo a partir da necessidade de um maior entendimento da hidrogeologia do aquífero fraturado, tendo em vista a presença de contaminantes no poço tubular e a necessidade de utilização da água do aquífero cristalino para abastecimento.

Através da aplicação de várias técnicas pouco usuais em investigação hidrogeológica de áreas contaminadas no Brasil, tais como perfilagens geofísicas e ensaios com obturadores de poços, procurou-se obter informações dos principais grupos de fraturas e os condicionantes geológicos da circulação de água e do transporte dos contaminantes no meio fraturado, o que propiciou a elaboração de um modelo conceitual hidrogeológico e da contaminação, etapa esta imprescindível que subsidia as demais ações de gerenciamento da área contaminada.

\section{OBJETIVOS}

O objetivo geral deste trabalho foi a elaboração de um modelo conceitual hidrogeológico da área de estudo, visando o entendimento do fluxo de água e transporte dos contaminantes do aquífero raso para o aquífero fraturado e pelas fraturas do aquífero cristalino. Os objetivos específicos foram:

- Caracterizar a geologia local no que diz respeito aos principais grupos de fraturas com relação às direções, mergulho, distribuição e atividade hidráulica; 
- Avaliação das cargas hidráulicas em diferentes profundidades no aquífero cristalino e caracterização dos potenciais hidráulicos entre os aquíferos;

- Caracterização química da contaminação da água subterrânea do aquífero fraturado e comparação com as principais áreas fonte.

\section{REVISÃO BIBLIOGRÁFICA}

\subsection{Características dos Compostos Organoclorados}

Para entendimento do comportamento dos contaminantes organoclorados nos diferentes meios é necessária a compreensão das propriedades químicas e físicas que regem sua distribuição e degradação.

Os organoclorados são compostos a base de carbono, com radicais de cloro, utilizados na indústria para fabricação de inseticidas, herbicidas, fungicidas, plásticos, solventes, desengraxantes e preservantes de madeira.

Os solventes clorados pertencem ao grupo dos hidrocarbonetos halogenados e podem ser divididos em hidrocarbonetos clorados alifáticos e aromáticos. Na área de estudo do atual trabalho, os principais solventes clorados utilizados e seus subprodutos de degradação, são detalhados na tabela abaixo:

Tabela 1 - Principais organoclorados

\begin{tabular}{|c|c|c|c|}
\hline ORGANOCLORADOS & SINÔNIMOS & FÓRMULA & CAS $^{*}$ \\
\hline Tetracloroeteno - PCE & Tetracloroetileno & C2Cl4 & $127-18-4$ \\
\hline Tricloroeteno - TCE & Tricloroetileno & C22HCl3 & $79-01-6$ \\
\hline 1,1-Dicloroeteno -1,1-DCE & 1,1-Dicloroetileno & C2H2Cl2 & $75-35-4$ \\
\hline Cis-1,2-dicloroeteno - Cis-1,2-DCE & Cis-Dichloroetileno & C2H2Cl2 & $156-59-2$ \\
\hline Trans-1,2-dicloroteno - Trans-1,2-DCE & Trans-Dichloroetileno & C2H2Cl2 & $156-60-5$ \\
\hline Cloreto de Vinila - CV & Cloroeteno; Cloroetileno & C2H3Cl & $75-01-4$ \\
\hline 1,1,1-Tricloroetano - 1,1,1-TCA & Metilclorofórmio; Tricloroetano & $\mathrm{C} 2 \mathrm{H} 3 \mathrm{Cl} 3$ & $71-55-6$ \\
\hline 1,1-Dicloroetano - 1,1-DCA & - & $\mathrm{C} 2 \mathrm{H} 4 \mathrm{Cl} 2$ & $75-34-3$ \\
\hline 1,2-Dicloroetano - 1,2-DCA & - & $\mathrm{C} 2 \mathrm{H} 4 \mathrm{Cl} 2$ & $107-06-2$ \\
\hline
\end{tabular}

$\left(^{*}\right)$ CAS é o número de registro de determinada substância presente no banco de dados do Chemical Abstracts Service.

Devido aos efeitos deletérios dos organoclorados aos organismos vivos e ao ambiente, seu uso vem sendo controlado e alguns compostos como o 1,1,1tricloroetano e tetracloreto de carbono foram inclusive banidos pelo Protocolo de Montreal (Ozone Secretariat). 
Os solventes clorados são incolores, e pouco solúveis em água, porém são miscíveis em vários solventes orgânicos. Podem ser encontrados na fase imiscível (fase livre ou residual), dissolvidos nas águas subterrâneas, adsorvidos nas partículas do aquífero e também na forma de vapor na zona não saturada.

Alguns dos compostos são altamente tóxicos e mesmo em baixas concentrações na água subterrânea ou na atmosfera, podem contaminar extensas áreas oferecendo riscos inaceitáveis a saúde humana e ao meio ambiente (Pankow e Cherry, 1996; Kueper et al, 2003).

A fase livre de organoclorados pode estar presente na forma contínua, formando bolsões (pools) na base do aquífero, ou no topo de camadas menos permeáveis, contribuindo para o aumento da contaminação em fase dissolvida. $\mathrm{Na}$ fase residual, o contaminante pode estar na forma de glóbulos ou gânglios aprisionados na zona saturada e não saturada.

Durante a migração dos solventes organoclorados na zona não saturada, ocorre uma partição entre a fase líquida, representada pela água, a fase sólida representada pelo solo e a fase gasosa, representada pelo ar. A distribuição do contaminante nos diferentes meios é controlada pelas propriedades e características de cada um dos compostos, apresentadas na tabela 2.

Tabela 2 - Propriedades físicas dos compostos de interesse.

\begin{tabular}{|c|c|c|c|c|c|c|c|c|c|}
\hline NOME & PCE & TCE & 1,1-DCE & $\begin{array}{c}\text { CIS-1,2- } \\
\text { DCE }\end{array}$ & \begin{tabular}{|l|} 
TRANS- \\
1,2-DCE \\
\end{tabular} & CV & $\begin{array}{l}1,1,1- \\
\text { TCA }\end{array}$ & $\begin{array}{l}1,1- \\
\text { DCA }\end{array}$ & $\begin{array}{l}1,2- \\
\text { DCA } \\
\end{array}$ \\
\hline $\begin{array}{c}\text { Peso } \\
\text { Molecular }{ }^{(1)}\end{array}$ & 165,83 & 131,39 & 96,94 & 96,94 & 96,94 & 62,5 & 133,4 & 98,96 & 98,96 \\
\hline $\begin{array}{c}\text { Densidade } \\
\left(\mathrm{g} / \mathrm{cm}^{3}\right) \text { a } 20^{\circ} \mathrm{C} \\
\text { (2) }\end{array}$ & 1,62 & 1,46 & 1,22 & 1,27 & 1,27 & 0,91 & 1,34 & 1,18 & 1,25 \\
\hline $\begin{array}{c}\text { Ponto de } \\
\text { ebulição }\left({ }^{\circ} \mathrm{C}\right) \\
(2)\end{array}$ & 121 & 87 & 31,7 & 60 & 48 & $-13,7$ & 73,9 & 57,3 & 83,6 \\
\hline $\begin{array}{l}\text { Henry (atm } \mathbf{m}^{3} \\
\quad / \mathrm{mol})(1)\end{array}$ & 0,0153 & 0,0091 & 0,021 & $0,0037^{(4)}$ & 0,00674 & 2,78 & 0,0162 & 0,00587 & 0,00098 \\
\hline Log Kow ${ }^{(2)}$ & 2,88 & 2,42 & 1,48 & 1,86 & 2,09 & 1,27 & 2,49 & 1,79 & 1,46 \\
\hline $\log K_{o c}^{(1)}$ & 2,42 & 1,81 & 1,81 & $1,93^{(4)}$ & 1,77 & 0,39 & 2,18 & 1,48 & 1,15 \\
\hline $\begin{array}{l}\text { Solubilidade a } \\
25^{\circ} \mathrm{C}(\mathrm{mg} / \mathrm{L})^{(1)}\end{array}$ & 150 & 1.100 & 5.000 & $3.500^{(4)}$ & 6.300 & 1.100 & 950 & 5.060 & 8.300 \\
\hline $\begin{array}{l}\text { Pressão de } \\
\text { Vapor (mm } \\
\mathrm{Hg}) \text { a } 25^{\circ} \mathrm{C}^{(1)}\end{array}$ & 20 & 72,6 & 591 & $200^{(3)}$ & 410 & 2.660 & 124 & 234 & 87 \\
\hline
\end{tabular}


FONTES: (1)Suthersan \& Payne, 2005; (2)Schwarzenbach, et al. 2005; (3) Fetter, 2008; (4)Pankow e Cherry, 1996.

Pode-se observar que os compostos, com exceção do cloreto de vinila, possuem densidade maior que a água $(1 \mathrm{~g} / \mathrm{cm} 3)$, sendo definidos como DNAPL (Dense Non-Aqueous Phase Liquids) e por isso, quando lançados no meio ambiente, infiltram nas zonas não saturadas e saturadas e podem migrar para regiões mais profundas do aquífero quando em concentrações acima do seu limite de solubilidade.

A volatilização de um composto está diretamente relacionada à sua pressão de vapor e Constante de Henry. Quanto maior é a pressão de vapor ou a constante de Henry, mais volátil é a substância. Compostos como tricloroeteno (TCE) e mesmo o tetracloroeteno (PCE) possuem uma pressão de vapor relativamente alta e são considerados voláteis.

A adsorção é o processo no qual os contaminantes dissolvidos na água aderem às partículas da matriz do material geológico e, apesar de não ser uma redução permanente das concentrações, a sorção causa o retardamento da migração da pluma de contaminação.

A quantidade de composto adsorvido pela matriz do aquífero depende principalmente da presença de matéria orgânica e argilominerais. Na maioria dos aquíferos, a fração orgânica tende a controlar a sorção dos contaminantes orgânicos (Wiedemeier, et al. 1999). Nestes casos, o coeficiente de distribuição do contaminante $(\mathrm{Kd})$ depende do coeficiente de partição do contaminante na fração orgânica do solo (Koc) e da quantidade de carbono orgânico. (Equação 1)

$$
\mathrm{Kd}=\mathrm{Koc} \cdot \mathrm{foc}
$$

Onde:

Koc $=$ coeficiente de partição normalizado pelo carbono orgânico foc $=$ fração de carbono orgânico

O Koc também conhecido como coeficiente de partição solo/água ou coeficiente de adsorção, é a medida da tendência de um composto orgânico ser adsorvido por solos ou sedimentos. Quanto maiores os valores de Koc e Kd, maior será a adsorção dos contaminantes e consequentemente menor a migração dos compostos. 
Já o Kow pode ser entendido como uma medida que define a hidrofobicidade de um composto orgânico. Quanto menor o Kow maior a tendência do composto permanecer dissolvido na água e maior sua mobilidade.

A maioria dos compostos orgânicos, incluindo os solventes clorados, pode ser naturalmente degradada por processos destrutivos, que promovem a redução da massa do contaminante. Já os processos chamados não destrutivos, que incluem a dispersão (difusão molecular e mecânica), adsorção e volatilização, retardam o avanço da pluma ou reduzem sua concentração, porém conservam a sua massa.

Dentre os processos destrutivos existem os processos bióticos (na presença de microrganismos) e os abióticos (ausência de seres vivos), que levam à transformação dos compostos iniciais (parentais) em compostos secundários de degradação (daugther products), por meio de reações que podem, ou não, ser intermediadas por microrganismos.

Segundo Wiedemeier et al. (1999), a biodegradação dos solventes clorados pelas bactérias através de reações de oxidação e redução entre as moléculas é provavelmente o mecanismo mais importante de degradação. Neste processo alguns compostos clorados podem ser utilizados como doadores de elétrons sendo oxidados, enquanto outros são utilizados como receptores de elétrons, sendo reduzidos.

Em condições aeróbicas os micro-organismos utilizam o oxigênio encontrado no meio para oxidar muitos dos compostos orgânicos, como hidrocarbonetos de petróleo e a matéria orgânica presente no meio. Na ausência de oxigênio, os microrganismos podem fazer uso das substâncias inorgânicas como receptores de elétrons, dando início à biodegradação anaeróbica dos contaminantes.

Receptores de elétrons são elementos em estados oxidados e incluem o oxigênio dissolvido, nitrato, ferro III, manganês IV, sulfato e dióxido de carbono. Esses compostos são reduzidos por meio de reações de oxi-redução durante a respiração microbiana para fornecer energia para as atividades e crescimento dos micro-organismos (USEPA, 2004). Os solventes clorados mais oxidados como PCE, TCE, DCE DCA e benzeno policlorados também podem agir como elétrons receptores (Suthersan \& Payne, 2005).

Os processos anaeróbicos ocorrem via desnitrificação, ferro redução, sulfato redução e metanogênese, originando subprodutos como nitrogênio gasoso, ferro (II), ácido sulfídrico e metano (USEPA, 2004). 
O principal mecanismo de degradação dos organoclorados ocorre predominantemente em meios anaeróbios pelo processo de decloração redutiva, no qual o solvente clorado age como um receptor de elétrons e neste processo um átomo de cloro é substituído por um átomo de hidrogênio, ocasionando a redução dos compostos.

Um resumo das reações bióticas e abióticas na sequência da decloração redutiva dos etenos e etanos é apresentado na figura 1.

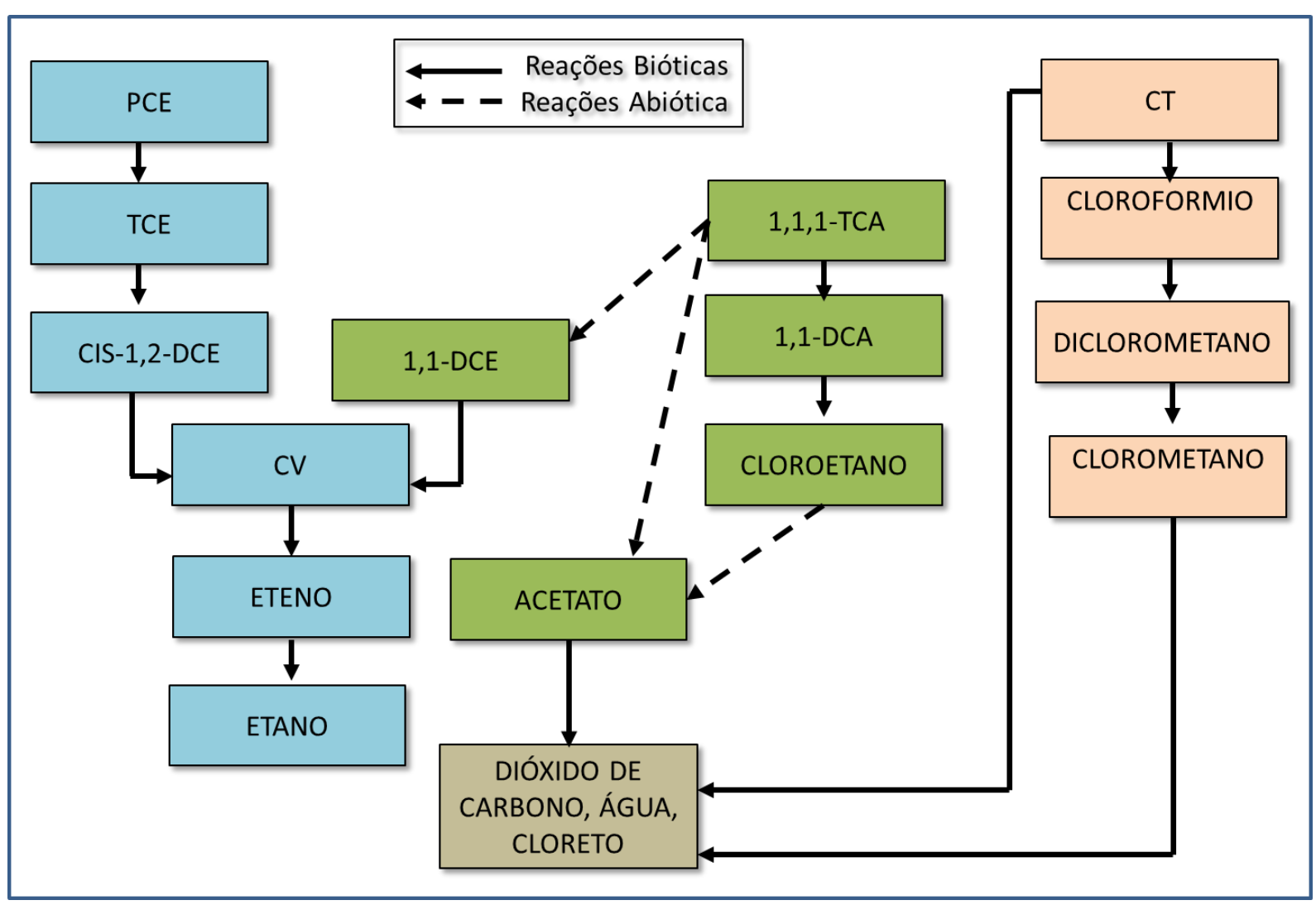

Figura 1 - Processos de transformação biótica e abiótica durante a redução de compostos clorados. (Modificado de Wiedemeier et al., 1999)

A decloração redutiva de compostos que se encontram em alto grau de oxidação devido à presença de átomos de cloro em suas moléculas, como o PCE e TCE por exemplo, ocorre rapidamente em meios anaeróbios, com baixo potencial de oxi-redução e quantidade suficiente de hidrogênio dissolvido. Quanto maior o grau de cloração, menor será a probabilidade de degradação em ambientes aeróbios, do mesmo modo que compostos com menor grau de cloração tendem a ser menos degradados em ambientes anaeróbios (USEPA, 1998). 
Assim, ambientes anaeróbios redutores podem propiciar a degradação de PCE e TCE até DCE, mas podem ocasionar o acúmulo de CV, já que a ausência de oxigênio no interior da pluma limitará sua degradação para eteno ou sua completa mineralização, formando dióxido de carbono e água (Suthersan \& Payne, 2005). Quando a biodegradação é completa, contaminantes dissolvidos são transformados em produtos inócuos, como dióxido de carbono, cloretos, metano e água, através do processo de mineralização (USEPA, 1998).

Apesar disso, em vários sites contaminados com eteno clorado, observou-se um acúmulo maior de 1,2-DCE em relação ao CV. Segundo Wiedemeier et al. (1999), isso pode ocorrer devido ao fato que o CV pode migrar para zonas que podem auxiliar a oxidação direta, seja ela aeróbica a/ou anaerobicamente.

Conforme visto, a degradação dos compostos orgânicos pode gerar acúmulos e aparecimento de outros compostos filhos que podem ser inclusive mais tóxicos que os compostos parentais.

O comportamento de cada contaminante em determinado meio irá depender das propriedades individuais de cada composto e do meio em que se encontra. A migração vertical descendente dos contaminantes dissolvidos na água ou em forma de DNAPLs, podem ocasionar a contaminação de aquíferos mais profundos, como é o caso do aquífero cristalino observado na área de estudo.

\subsection{Fluxo de Água e Transporte de Contaminantes em Aquíferos Fraturados}

As rochas metamórficas ou ígneas, também chamadas de "rochas duras" (hard rocks), pertencem ao grupo das rochas cristalinas de baixa porosidade intergranular, e por muito tempo foram inclusive consideradas como impermeáveis. Segundo Feitosa \& Filho (2000), "medidas de condutividade hidráulica de granitos em poços sem fraturas, geralmente fornecem valores da ordem de $10^{-11} \mathrm{~m} / \mathrm{s}$, o que equivale a dizer que essas rochas podem ser consideradas como impermeáveis no contexto dos problemas de aproveitamento de água subterrânea". Nesse tipo de embasamento, a água subterrânea pode ser encontrada no manto de alteração (aquífero freático) ou nas descontinuidades no maciço rochoso (aquífero fraturado).

Essas rochas sofrem intemperismo (conjunto de modificações de ordem física e química), criando condições favoráveis para infiltração e transporte de água. A ação do intemperismo nos diferentes tipos de rocha leva à formação de um manto 
de alteração, também chamado de manto de intemperismo, saprolito, ou ainda manto inconsolidado (Fernandes, 1997), e sua espessura é determinada pela influência do clima, relevo, fauna, flora, rocha parental e tempo de exposição aos agentes intempéricos.

O manto de intemperismo constitui uma importante zona de recarga para 0 aquífero cristalino e pode, inclusive, ser uma fonte importante de captação de água.

Já em uma rocha sã, não intemperizada, o armazenamento e fluxo de água subterrânea é controlado pelas descontinuidades do pacote rochoso desenvolvida após a consolidação (cristalização) da rocha, conferindo ao meio uma porosidade secundária.

O fluxo de água subterrânea nas fraturas é controlado pela densidade de fraturas, abertura e conectividades das mesmas (Domenico \& Shwartz, 1990) e o sentido do fluxo sofre influência da direção e mergulho das fraturas (atitude). Em subsuperfície a abertura das fraturas também sofre a influência do intemperismo em que as mesmas são impostas.

As fraturas são feições geradas por deformação rúptil, decorrente do comportamento das rochas face aos esforços mecânicos impostos pela tectônica, pela contração da rocha durante o resfriamento de sua massa, alivio de pressão, compressão causada por subsidência e enterramento do pacote e/ou pela pressão de fluidos (Fetter, 2001). Esses esforços ocasionam, em função da competência das rochas, o surgimento de um conjunto de rupturas na forma de fraturas ou falhas.

A resistência da rocha à ruptura depende das características intrínsecas e estruturais de formação da rocha. Em um mesmo evento tectônico é possível encontrar rochas com diferentes graus de fraturamento. Isso ocorre devido à presença de descontinuidades prévias e propriedades mecânicas da rocha, diferentes graus de metamorfismo, de estrutura, composição, tamanho dos grãos e idade das rochas, que são fatores determinantes para o desenvolvimento de fraturas que por sua vez estão diretamente relacionados à possibilidade de existência de água. Deste modo, o cenário tectônico e geológico são fatores fundamentais a serem analisados nas áreas de aquíferos fraturados (Fernandes, 1997).

A abertura das fraturas depende principalmente do mecanismo de sua propagação (Lawn \& Wilshaw, 1993) que por sua vez, é controlado pela magnitude dos principais esforços (máximo o1 e mínimo $\sigma 3$ ) que atuam na rocha. 
As fraturas podem ser geradas por esforços de tração (modo I), no qual ocorre uma abertura ou separação normal aos planos de ruptura, ou por esforços de cisalhamento, que podem ser perpendiculares (modo II) ou paralelos (modo III) à frente de propagação da ruptura (figura 2).

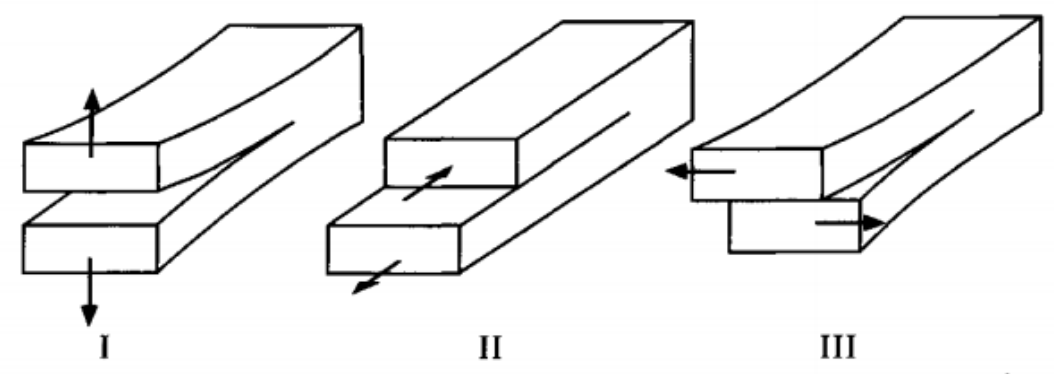

Figura 2 - Modos de propagação de fraturas por extensão perpendicular à superfície da fratura (I) e por cisalhamento perpendicular (II) ou paralelo (III) à frente de propagação da ruptura. Modificado de Lawn \& Wilshaw (1993)

As fraturas geradas pelo Modo I são chamadas de juntas ou fraturas extensionais e se originam perpendicularmente ao esforço mínimo principal ( $\sigma 3)$. As fraturas dos modos II e III são chamadas de fraturas de cisalhamento e são geradas sob o esforço diferencial compressivo $(\sigma 1-\sigma 3)$, no qual as fraturas ocorrem em planos conjugados, formam um angulo agudo com o esforço máximo $\sigma 1$, e um ângulo obtuso com $\sigma 3$. As chamadas fraturas hibridas podem ser geradas pela atuação dos três modos de propagação acima descritos.

A identificação dos diferentes tipos de fraturas em campo auxilia no entendimento dos possíveis caminhos preferenciais de fluxo, visto que o modo de propagação da fratura exerce grande influência sobre sua abertura.

Estruturas plumosas (plume) e do tipo "costela" (rib) são feições comumente encontradas nas superfícies de fraturas extensionais (Fernandes, 2008) e nas fraturas de cisalhamento podem ser observadas estrias ou outros indicadores cinemáticos.

Uma vez que o fluxo e transporte de água em rochas cristalinas é função das descontinuidades presentes no meio geradas pelos diferentes esforços acima citados, estas são consideradas anisotrópicas e heterogêneas por natureza.

No entanto, dependendo da escala de trabalho, a análise de fluxo de água nas fraturas pode ser realizada utilizando a abordagem de meios contínuos caso o fraturamento seja denso o suficiente a ponto do meio fraturado comportar-se 
hidraulicamente de forma similar a um meio poroso granular (Custodio \& Llamas, 1996; Fernandes, 1997; Freeze \& Cherry, 1979).

Nesta abordagem, primeiramente deve-se definir o Volume Elementar Representativo (VER ou representative elementary volume) (Bear, 1979, Freeze \& Cherry 1979), que constitui o mínimo volume de rocha necessário para a definição dos parâmetros hidráulicos que são considerados representativos do meio fraturado. Importante ressaltar que "como a frequência e a abertura das fraturas variam muito, o meio fraturado, mesmo quando considerado homogêneo, se comportará como anisotrópico e apresentará diferentes condutividades hidráulicas em diferentes direções" (Neves, 2005).

A condutividade do meio fraturado utilizando a abordagem de meios contínuos (fluxo laminar e linear) pode ser obtida por meio da Lei Cúbica desenvolvida por Snow (1969) na qual a condutividade hidráulica do meio (K) é dada por:

$$
\mathrm{K}=\frac{\rho \mathrm{g}}{12 \mu} \cdot \mathrm{N} b^{3}
$$

onde:

$\rho=$ densidade da água $\left(\mathrm{kg} / \mathrm{m}^{3}\right)$;

$\mu=$ viscosidade da água $(\mathrm{kg} / \mathrm{m} . \mathrm{s})$;

$\mathrm{g}=$ aceleração da gravidade $\left(\mathrm{m} / \mathrm{s}^{2}\right)$;

$\mathrm{N}$ = número de fraturas por unidade de distância;

$b=$ abertura das fraturas $(m)$.

A Lei Cúbica mostra que a abertura das fraturas exerce maior influência que a densidade das fraturas (figura 3) na determinação da condutividade hidráulica, visto que o $K$ nos meios fraturados é proporcional ao cubo da abertura da fratura, e a densidade do fraturamento, ditada pela frequência ou espaçamento, causa variação apenas linear. 


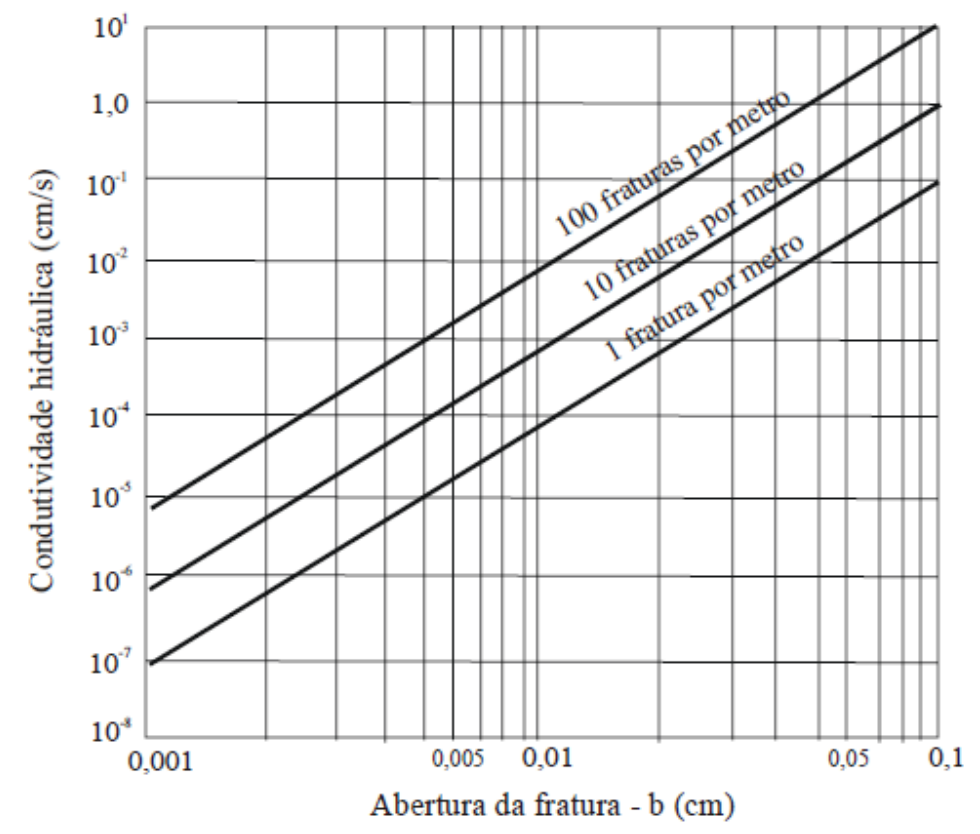

Figura 3 - Variação da condutividade hidráulica em função da abertura (b) e da densidade da fratura (Hoek \& Bray, 2005)

No entanto, dependendo das características da rocha fraturada, o volume elementar representativo (VER) pode não existir, ou ainda ser tão grande a ponto de não ser possível sua definição. Neste caso deve-se avaliar a hidráulica do fluxo de fraturas individuais ou das zonas de fraturas, através da abordagem de meios descontínuos (Fernandes, 2008).

Neste caso, a abertura da fratura ou a abertura equivalente de um número desconhecido de fraturas abertas que atravessam um poço, pode ser determinada de modo indireto através da medição da transmissividade ( $\mathrm{T}$ ) de um dado intervalo por meio de ensaios realizados em campo. A Transmissividade (T) pode ser definida pela seguinte equação (Novakowski, 1995):

$$
T=\frac{\rho g(2 b)^{3}}{12 \mu}
$$

$\rho=$ densidade da água $\left(\mathrm{kg} / \mathrm{m}^{3}\right)$;

$\mu=$ viscosidade da água $(\mathrm{kg} / \mathrm{m} . \mathrm{s})$;

$\mathrm{g}=$ aceleração da gravidade $\left(\mathrm{m} / \mathrm{s}^{2}\right)$;

$\mathrm{b}=$ somatória das aberturas das fraturas individuais atravessadas pelo poço.

No entanto, dados coletados em diferentes intervalos podem fornecer resultados diferentes a respeito das propriedades da rocha. Segundo Neuman, 
(2005) toda a evidência sugere que raramente um modelo de fluxo e transporte em um aquífero fraturado pode ser consistente, tratando-o como um meio isotrópico continuo uniforme ou levemente uniforme.

Observa-se que tanto para meios contínuos quanto para meios descontínuos, a condutividade hidráulica é fortemente influenciada pela abertura das fraturas, que é fator fundamental para a produtividade dos poços em terrenos cristalinos e para o entendimento do fluxo e transporte de contaminantes nesses meios.

As equações apresentadas podem também ser aplicáveis para condições não ideais de fluxo laminar e linear, obtendo assim, medidas de abertura hidráulica das fraturas, e não abertura real.

Conforme observado em testes hidráulicos, muitos estudos indicam que grande parte do fluxo de água provém de uma pequena população de algumas fraturas individuais ou zonas de fraturas que interceptam o furo (Paillet et al., 1987; Paillet, 1995). Nowakovski (1995) verifica a mesma relação na circulação e transporte de contaminantes.

O contaminante dissolvido entra na rocha fraturada seguindo o sentido do fluxo de água, que é determinado pelo gradiente hidráulico do meio. Em fase livre, os organoclorados que possuem densidade maior que a água, ao entrarem em contato com o topo rochoso adentrarão nas fraturas, sendo o fluxo do contaminante controlado primeiramente pela direção e mergulho da rede das fraturas mais permeáveis.

A pressão de entrada do contaminante na fratura é diretamente proporcional à tensão interfacial e inversamente proporcional à abertura da fratura, resultando em uma migração do DNAPL preferencialmente pelas fraturas com maiores aberturas (Kueper et al., 2003).

Assim como no solo, o DNAPL ao entrar no maciço rochoso também estará sujeito aos processos de adveção, dispersão, difusão, degradação e adsorção, se dissolvendo lentamente no meio.

O processo de difusão é um processo físico, no qual por diferença de concentração o soluto dissolvido na água pode migrar para outras regiões e ser adsorvido para a matriz da rocha (Matrix Diffusion). Caso a concentração na fratura seja menor que a concentração adsorvida na matriz rochosa, o soluto irá lentamente se mover para a água existente na fratura aberta. Esse processo é conhecido como 
Back Diffusion ou difusão reversa e pode ocorrer durante centenas de anos, visto que a velocidade do processo de saída do contaminante adsorvido é menor que a velocidade de entrada no meio. Isso porque o soluto continua a migrar para regiões ainda mais profundas da matriz porosa e a diferença de concentração para ocorrer a difusão reversa é menor que a diferença inicial de concentração que ocasionou a adsorção do contaminante no meio (Kueper et al., 2003).

Devido à adsorção, a migração das plumas pode ser significativamente atenuada quando comparada com o fluxo da água subterrânea, principalmente nas rochas com maior porosidade primária. No entanto, apesar da menor velocidade de caminhamento das plumas, a remediação dessas áreas torna-se difícil e demorada devido à difusão reversa dos contaminantes para a água ao longo do tempo.

\subsection{TÉCnicas de inVestigação em Aquíferos Fraturados}

Tendo em vista as propriedades que regem o fluxo de água e transporte de contaminantes e considerando as características de grande parte dos compostos organoclorados, que possuem densidade maior que a água e baixa viscosidade, a investigação e delimitação em subsuperfície das áreas contaminadas devem ser realizadas levando em consideração a análise de diferentes linhas de evidências, a fim de se obter resultados mais confiáveis.

A identificação da fonte primária de contaminação e as características do contaminante são fatores fundamentais para planejamento das etapas de investigação. Para entendimento do modo de propagação da contaminação no meio, é necessária uma boa compreensão da geologia local, juntamente com a análise do relevo, hidrografia e hidrogeologia. Existindo a possibilidade da contaminação ter atingido o meio fraturado, é necessária a identificação e análise das fraturas e das zonas de fraturas de maior permeabilidade existentes na área, que irão condicionar o fluxo de água e o transporte de contaminantes.

A investigação das fraturas pode ser realizada através de abordagens diretas, nas quais o levantamento das características das fraturas é feito diretamente nos afloramentos de rocha, ou através de métodos indiretos de investigação, onde os dados são obtidos indiretamente pela interpretação de lineamentos, fotografias aéreas e imagens de satélites, geofísica de superfície e de poço, entre outros (Fernandes, 2008). 
Atualmente observa-se uma crescente produção de trabalhos relacionados ao desenvolvimento e aprimoramento de técnicas mais eficientes e menos custosas de investigação direta de aquíferos fraturados contaminados por DNAPL. Umas das abordagens para estudo de solventes clorados em aquíferos fraturados sedimentares é chamada DFN (Discrete Fracture Network Approach) (Parker, 2007), que se baseia na investigação em alta resolução das redes de fraturas e das propriedades da matriz da rocha, realizada em três dimensões em um detalhamento apropriado. O fluxograma abaixo (figura 4) apresenta as etapas da abordagem DFN.

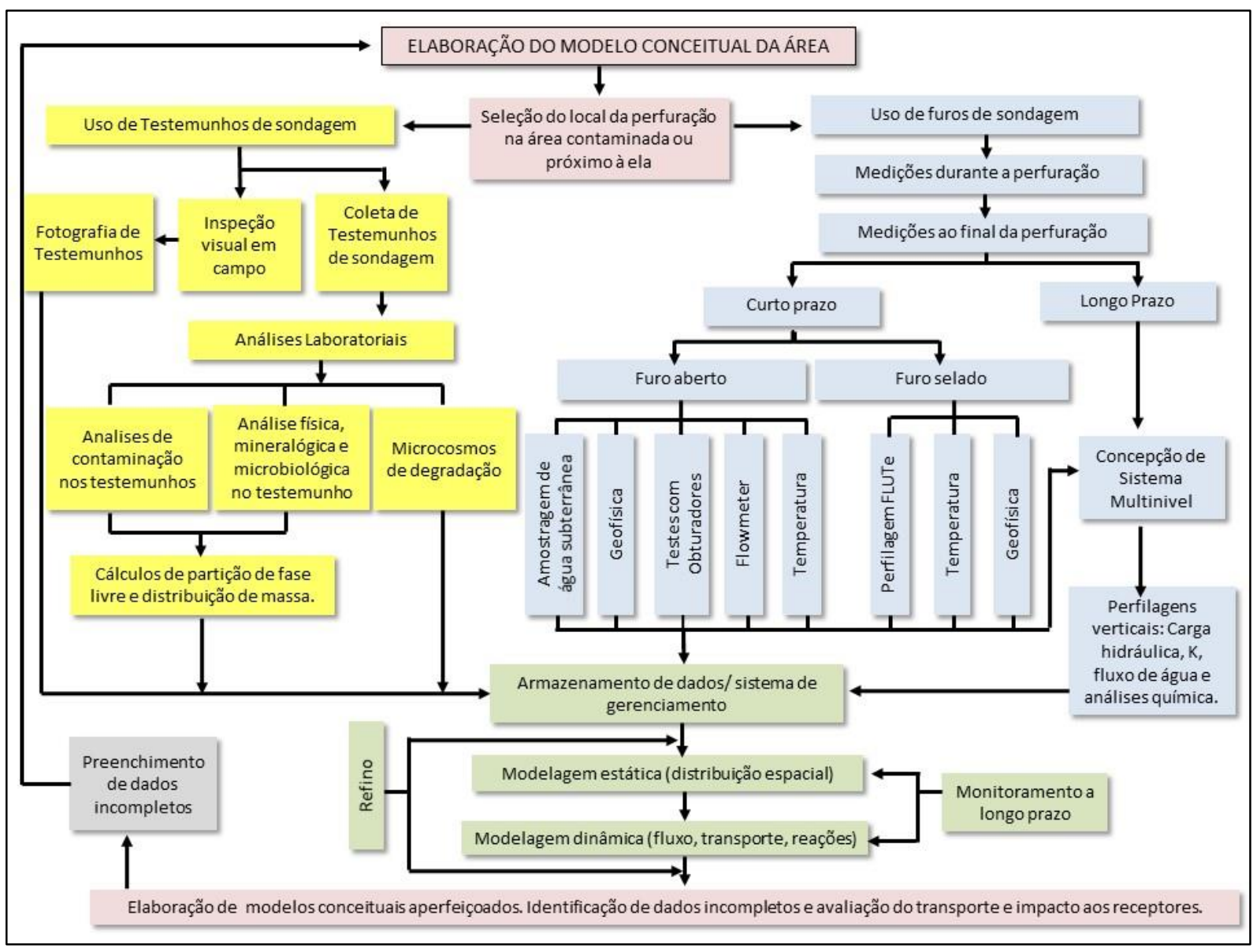

Figura 4 - Etapas Abordagem DFN (modificada de Parker, 2012)

O objetivo de utilização desta metodologia vem da necessidade do desenvolvimento de modelos conceituais confiáveis de cada local, através de intenso estudo em áreas já contaminadas, a fim de melhor entender a influência dos vários processos que atuam durante a formação e evolução das plumas, como a advecção, dispersão, retardação e degradação em meios fraturados, mais especificamente de rochas sedimentares. 
Neste tipo de rocha a porosidade efetiva geralmente é da ordem de 2 a $20 \%$, possibilitando a transferência de massa química por difusão entre as fraturas e a matriz da rocha, causando forte influência no comportamento da contaminação (Parker, 2012).

Deste modo, a amostragem somente da água subterrânea das fraturas não representa a distribuição real da massa de contaminantes nesses meios, visto que nas rochas sedimentares, grande parte da massa de contaminantes reside na matriz porosa da rocha, que apresenta baixa permeabilidade, e não nas fraturas (Parker, 2007).

A abordagem DFN desenvolvida engloba a avaliação não somente das fraturas como também da matriz rochosa, com a coleta de amostras de rocha, para análise química em intervalos pouco espaçados, proporcionando uma medição direta da distribuição da massa do contaminante na matriz rochosa.

Estudos realizados mostram ainda que a comparação do perfil de contaminação dos testemunhos de rocha com os resultados das análises de água subterrânea realizadas em poço de monitoramento convencional ou multiníveis, apresentam resultados enganosos, devido ao fluxo vertical nos furos quando esses estavam abertos, permitindo a contaminação cruzada de fraturas com concentrações iniciais diferentes (Sterling et al., 2005).

A maioria dos métodos e ensaios que são hoje utilizados para investigação de aquíferos fraturados é realizada em furos abertos e consiste basicamente na inserção de um equipamento para aquisição de dados dentro do furo. Neste contexto, o desafio da abordagem DFN é identificar, aprimorar e desenvolver novos métodos de investigação para aquisição de dados do furo referente ao fluxo ambiente (natural) da rede de fraturas, evitando ao máximo as conexões cruzadas dentro do furo. Apesar da abordagem DFN ter sido desenvolvida especificamente para rochas sedimentares, a metodologia é relevante para todos os tipos de rocha, no entanto a coleta de testemunhos de rocha deve ser ajustada para se adequar à porosidade da matriz.

Nos aquíferos cristalinos a porosidade primária da matriz da rocha é mínima, sendo o fluxo da água e transporte do contaminante nesses meios controlados principalmente pelo tamanho, abertura e conectividade da rede de fraturas (porosidade secundária). Deste modo, identificar as zonas de fraturas é o primeiro 
passo para a investigação e remediação de água subterrânea no maciço rochoso (Cho et al., 2008).

Devido à densidade maior que a água, baixa viscosidade da maioria dos compostos organoclorados e à baixa porosidade das rochas cristalinas, é esperado que o DNAPL migre pelas fraturas a profundidades consideráveis dentro do meio rochoso. É sabido que um volume relativamente pequeno de DNAPL tem um potencial de contaminar extensas áreas de rocha. Além disso, mesmo baixas concentrações do contaminante dissolvido pode migrar em profundidade, devido ao potencial vertical descendente de fluxo.

Assim, uma vez que o transporte dos contaminantes em aquífero fraturados segue o caminho e direção das fraturas mais permeáveis, um grande número de poços pode ser necessário para estimar a profundidade do impacto vertical e horizontal do contaminante, sendo uma investigação bastante custosa. Existe ainda o risco associado à perfuração nas áreas fonte, que pode possibilitar a remobilização do contaminante e sua migração a porções mais profundas do aquífero. Deste modo, a investigação nesses meios deve ser realizada com cautela, levando em consideração as concentrações já identificadas no meio poroso, ou poços profundos já existentes, e avaliando a possibilidade de existência de fase livre, incluindo ainda um plano de contingência para identificação de DNAPL durante as atividades de perfuração.

Caso exista ainda a contaminação no solo, a perfuração de novos poços próximos à área fonte deverá ser realizada com o revestimento do manto inconsolidado até o topo rochoso, a fim de evitar o favorecimento da migração do contaminante durante a perfuração. Da mesma forma, ensaios de bombeamento em poços instalados na rocha e localizados próximos às fontes de contaminação devem ser evitados, uma vez que o DNAPL pode ser mobilizado para regiões mais profundas.

A perfuração de poços com recuperação de testemunhos é bastante custosa e a coleta e recuperação de testemunhos em rochas cristalinas muito alteradas ou intensamente fraturadas pode ser bastante difícil. Neste sentido as perfilagens geofísicas de poço auxiliam na identificação e caracterização das fraturas ao longo do perfil do furo, porém é importante lembrar que a investigação em rochas deve englobar diferentes técnicas para aquisição de dados hidrogeológicos, químicos e hidrológicos da área de estudo. 
Dentre as técnicas mais utilizadas estão as realizadas em superfície, como levantamento geológico, geofísica de superfície, interpretação de lineamentos além das técnicas utilizadas em subsuperfície como as perfilagens geofísicas de poço (detalhadas mais adiante), quantificação de fluxo de água, ensaios de bombeamento e testes hidráulicos, dentre outras, que vêm sendo aprimoradas.

Tendo em vista as descontinuidades presentes no meio, os obturadores pneumáticos são também utilizados com o objetivo de isolar determinado intervalo de interesse dentro do furo permitindo a realização de ensaios hidráulicos e/ou a caracterização química com a coleta de amostras de água em intervalos específicos.

A interpretação e análise em conjunto dos dados individuais coletados é a principal ferramenta para $\mathrm{o}$ entendimento e desenvolvimento de um modelo conceitual da área mais coerente com a realidade, que auxiliará a tomada de decisão com relação às etapas de gerenciamento, remediação e monitoramento.

\subsubsection{Imageamentos e Perfilagens Geofísicas}

A perfilagem de poços é amplamente utilizada na indústria do petróleo e atualmente é uma ferramenta indispensável para a hidrogeologia, uma vez que auxilia no levantamento das fraturas hidraulicamente ativas, no entendimento de fluxo de água e transporte de contaminantes e na identificação de diferentes litologias.

Sua aplicação na área da hidrogeologia teve início na década de 60 , com a utilização das perfilagens na coleta de informações para investigação dos recursos hídricos subterrâneos, sendo os equipamentos utilizados na indústria do petróleo adaptados para este fim (Keys, 1968).

Com o passar dos anos, as tecnologias de perfilagem foram aprimoradas e utilizadas em diversos estudos para identificação de fraturas em aquíferos sedimentares e cristalinos, conforme descrito por Paillet \& Ollila, 1994; Barton et al., 1995; Paillet, 1995; Stumm et al., 2001; Johnson et al., 2002, Williams \& Johnson, 2004; e Wahnfried, 2010.

A perfilagem geofísica, corresponde ao registro de determinada propriedade petrofísica em diferentes profundidades de um poço ou furo por equipamentos com sensores puxados por cabos elétricos, que se deslocam continuamente dentro do meio perfilado (Feitosa \& Filho, 2000). 
Em uma mesma sonda, mais de um parâmetro pode ser medido, porém o princípio envolvendo a operação do ferramental é o mesmo. Todas as sondas possuem uma fonte e um receptor. A sonda, controlada através de um guincho conectado a uma interface, envia um sinal através da fonte para o meio a ser estudado e cada material responderá de forma distinta. A resposta é registrada pela sonda através de receptores enquanto esta percorre o furo. A figura 5 mostra um esquema simplificado da técnica de perfilagem de poços.

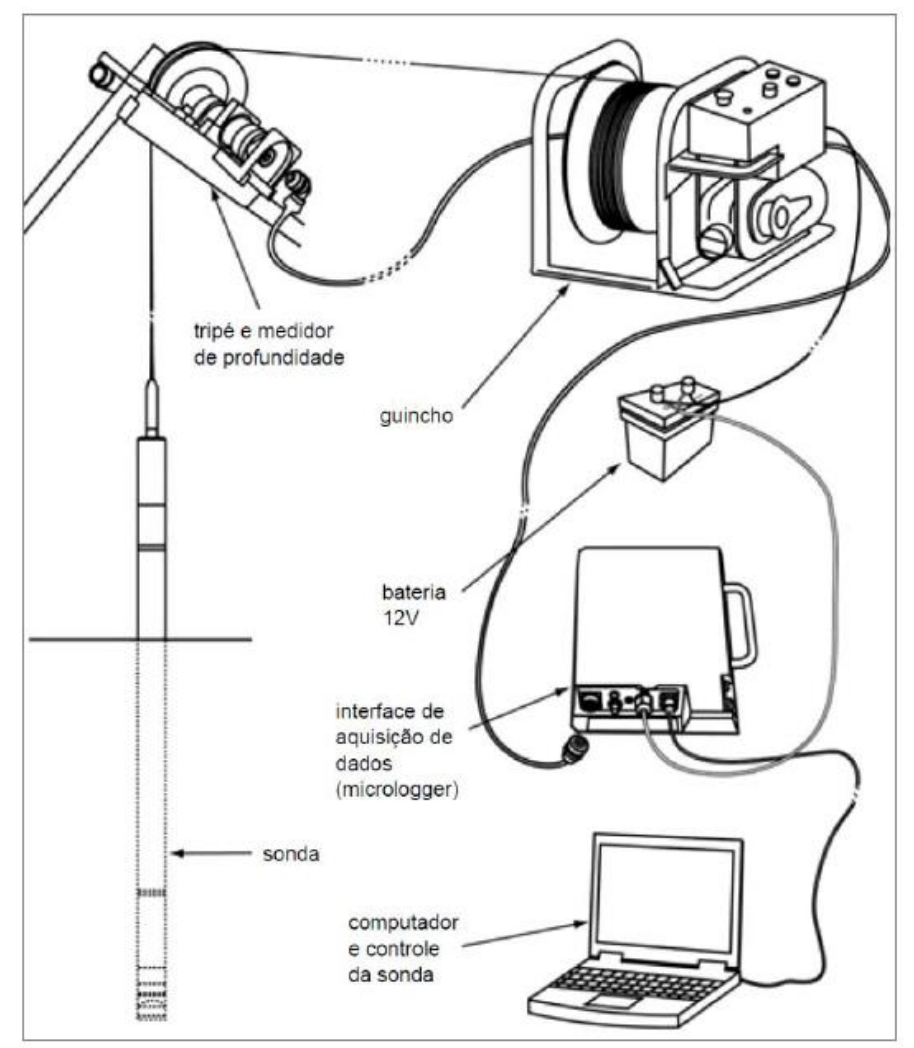

Figura 5 - Arranjo dos equipamentos utilizados para a execução das perfilagens geofísicas (modificado de Hubbard et al.2008; extraído de Ribeiro, 2012)

As perfilagens geofísicas podem ser aplicadas em poços, auxiliando na indicação de possíveis fraturas ou zonas de fraturas mais transmissivas, e na definição dos intervalos e profundidades para colocação dos obturadores.

Os imageamentos óticos e acústicos, por gerarem imagens orientadas, possibilitam a determinação das atitudes (direção e mergulho) das fraturas, sendo uma ferramenta imprescindível para o detalhamento das características do aquífero.

Deste modo, as perfilagens convencionais interpretadas juntamente com o uso de técnicas mais sofisticadas de imageamento ótico e acústico, permitem a identificação e caracterização das principais zonas de fraturas que interceptam um 
poço, auxiliando na elaboração de modelos conceituais de fluxo de água e transporte de contaminantes mais próximos da realidade.

No Brasil, os trabalhos desenvolvidos por Nery \& Macari (2006) e Wanhfried (2010) nas rochas basálticas da formação Serra Geral, Fiume (2013) em aquíferos cristalinos situados na cidade de São Paulo, e Guerra (2010), em aquífero fraturado do itabirito em Nova Lima-MG, são alguns exemplos de recentes estudos que se utilizam de diferentes técnicas de geofísica para investigação do aquífero fraturado.

No atual trabalho foram realizadas as perfilagens de calibre de poço, radiação natural gama, imageamento acústico (ATV) e filmagem do poço, além de medições de fluxo d'água utilizando a sonda Heatpulse Flowmeter, que são descritos a seguir.

\section{Perfilagem de calibre de poço}

A perfilagem de calibre, também chama de Cáliper (ou compasso calibrador), tem como objetivo informar a variação de diâmetro e rugosidade ao longo de toda a parede do furo, avaliando sua integridade e auxiliando na identificação de possíveis zonas de fraqueza da rocha, sendo fundamental para verificar os intervalos apropriados para amostragem e colocação dos obturadores.

Esse tipo de perfilagem é realizado por um equipamento composto por hastes articuladas que são posicionadas no fundo do furo e pressionadas contra a parede enquanto são tracionadas e puxadas desde o fundo do poço até a superfície. Ao longo do trajeto, as mudanças de diâmetro da sondagem, como possíveis cavidades relacionadas a fraturamentos ou zonas de fraquezas que foram desgastadas durante a perfuração, provocam variações na abertura das hastes. Todas estas variações são registradas e informadas conforme a unidade de medida adotada pelo equipamento utilizado e podem ser visualizadas em tempo real através dos computadores que recebem a informação na superfície. Cabe ressaltar que fraturas pequenas ou com aberturas sutis podem não ser detectadas neste método, porém podem ser observadas na perfilagem acústica, por exemplo.

\section{Perfilagem de Raios Gama}

A perfilagem de raios gama convencional, ajustada para finalidades geológicas, mede a radioatividade natural presente nos materiais geológicos como solos, sedimentos e rochas, através da detecção da radiação gama emitida durante o 
decaimento natural dos isótopos potássio $\left({ }^{40} \mathrm{~K}\right)$ e pelos elementos radioativos das séries do urânio ( ${ }^{238} \mathrm{U}$ ) e tório ( ${ }^{232} \mathrm{Th}$ ) (Adams e Gasparini, 1970).

O fenômeno de radioatividade ocorre quando um átomo instável sofre decaimento radioativo e seu núcleo libera energia sob forma de onda eletromagnética a fim de se tornar mais estável. Na medida em que a sonda avança em profundidade, é realizado o registro continuo dos pulsos (CPS - contagem de choques por segundo ou counts per second) da radiação natural gama ( $\mathrm{Y})$. Nenhum sinal é emitido pela sonda neste tipo de perfilagem.

O potássio, urânio e tório são elementos comumente encontrados em micas, feldspatos e argilominerais (Johnson et al., 2002). Por essa razão, sedimentos finos que contêm argila em abundância tendem a ser mais radioativos do que areias quartzosas ou rochas carbonáticas, embora numerosas exceções ocorram (Keys, 1990).

O potássio natural contém cerca de $0,012 \%$ do isótopo radioativo ${ }^{40} \mathrm{~K}$ (Guerra 2010, Minty, 1997). Elevados teores de K são encontrados em rochas ígneas félsicas (granitoides e sienitoides, e seus equivalentes vulcânicos), e em rochas metamórficas micáceas, feldspáticas e quartzo-feldspáticas (e.g., filitos, xistos e gnaisses), sendo também constituinte importante em rochas sedimentares (e.g., arcósios; lamitos, folhelhos e argilitos) (Ulbrich et al., 2009).

Devido a sua natureza ondulatória, alta energia e ausência de carga, os raios gama (também chamado de fótons), possuem alta capacidade de penetração em materiais densos, sendo detectados pelos equipamentos convencionais de perfilagem (Feitosa e Filho, 2000).

Os raios gama podem penetrar até $30 \mathrm{~cm}$ na rocha (Minty, 1997) auxiliando na identificação de diferentes litotipos, fornecendo dados qualitativos da presença dos minerais na rocha. Na hidrogeologia, o perfil de raios gama auxilia também na identificação dos melhores intervalos para instalação dos filtros dos poços, uma vez que os materiais de granulometria fina, como os argilominerais, que possuem alto teor de mica e feldspatos, têm reduzidas as suas porosidades e permeabilidades efetivas, e sua presença pode colmatar os filtros instalados.

\section{Imageamentos Acústico (Acoustic Televiewer - ATV) e Ótico (OTV)}

As perfilagens ATV e OTV são baseadas, respectivamente, nos imageamentos acústico e ótico da seção perfurada. Esta técnica é aplicada na identificação e 
orientação de fraturas, em trabalhos de reconhecimento estratigráfico e em estudos estruturais, uma vez que esta perfilagem gera uma imagem contínua, orientada e plana e em $360^{\circ}$ da parede do furo (Williams \& Johnson, 2004).

Em ambos os métodos, a orientação da imagem em relação ao norte geográfico é realizada por um magnetômetro triaxial e três acelerômetros. Para se obter uma imagem de boa qualidade e corretamente orientada, é necessária a utilização de adaptadores flexíveis que centralizam a ferramenta utilizada no interior do furo.

O imageamento acústico (ATV), também chamado de "borehole televiewer" (BHTV), utiliza uma sonda ultrassônica na qual uma fonte transmissora de frequência constante emite ondas sonoras compressionais que se deslocam dentro do poço e são identificadas por receptores localizados a diferentes distâncias. Em geral, duas saídas de dados são registradas: uma mostra variações de tempo de trânsito e outra de amplitude da onda. Essas variáveis podem ser então utilizadas para determinação da porosidade ou identificação de fraturamentos na parede do poço. O som se propaga com diferentes velocidades, sendo mais rápido nos sólidos do que em meios líquidos e gasosos. Ampliações na parede do furo, como a presença de fraturas, ou foliações, dissipam a energia da onda acústica, reduzindo o sinal da amplitude e aumentando o tempo de trânsito (Paillet et al., 1990), gerando um contraste na imagem pelas diferenças de densidade.

O sistema de imageamento ótico (OTV) utiliza um refletor cilíndrico convexo para projetar a imagem de $360^{\circ}$ da parede do furo na lente de uma câmera que grava continuamente a imagem obtida. Um anel de luz (LEDs) localizado na extremidade da sonda é utilizado para iluminar a parede do furo (Hubbard et al,. 2008). Métodos mais novos já captam a imagem em sinal digital. A velocidade de subida do equipamento durante o registro de imagens depende da resolução pretendida e do tipo de equipamento utilizado. O OTV pode ser utilizado em furos preenchidos com água límpida ou ar, sendo que a falta de luminosidade no furo, ocasionada pela presença de poeira, lama, alta turbidez, precipitação química, ou mesmo crescimento bacteriano, afetam a qualidade da imagem obtida.

Os resultados dos imageamentos são apresentados como imagens planas, com a orientação já ajustada em relação ao norte no eixo $x$, permitindo a determinação precisa das atitudes das fraturas atravessadas pelo furo. 
As fraturas que interceptam a seção perfurada aparecerão como uma linha escura na imagem de amplitude, e uma linha clara na imagem de tempo de trânsito gerada (figura 6).

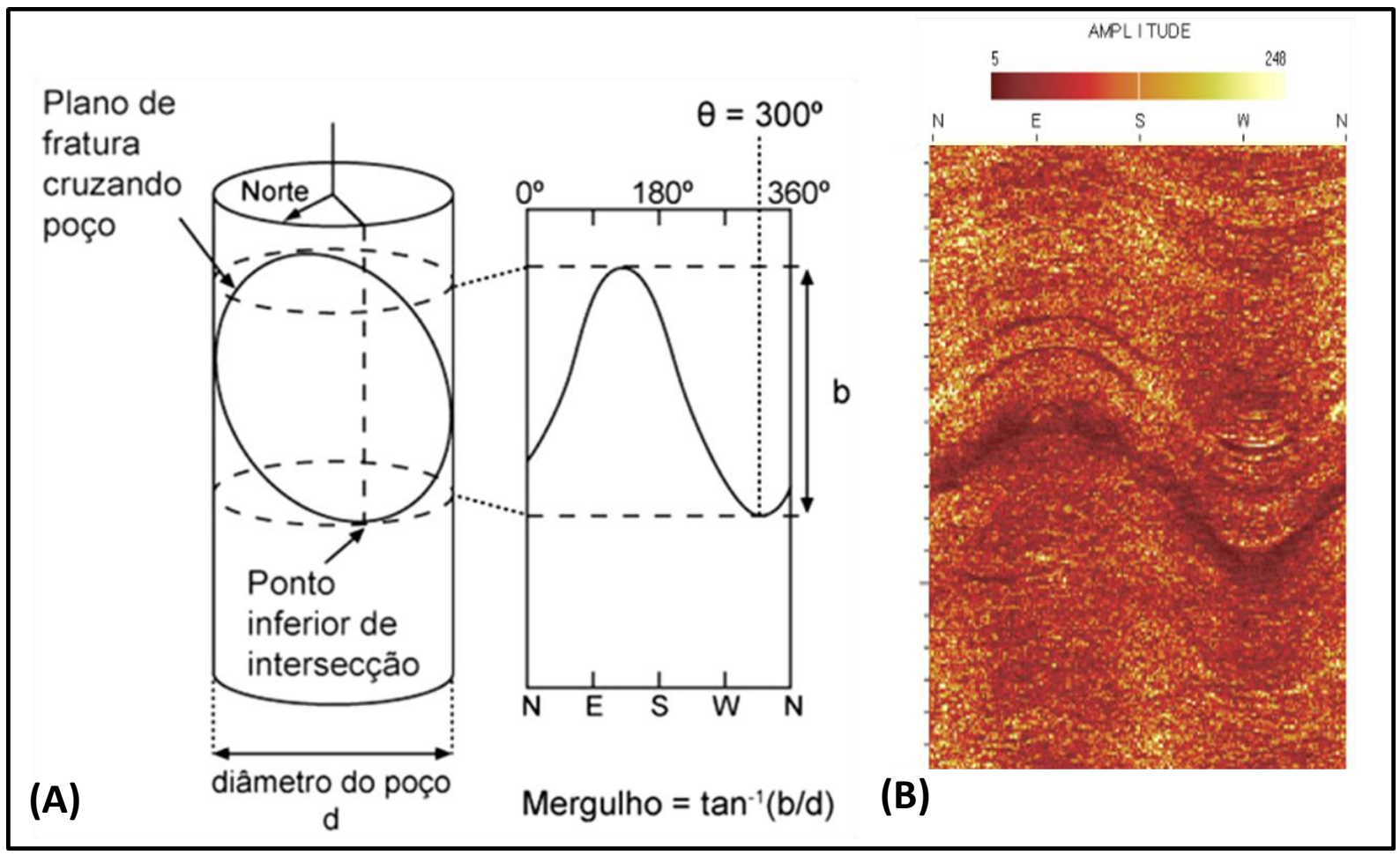

Figura 6 - (A) Representação plana do imageamento acústico (ATV ou BHTV) de uma feição de fratura que intercepta o poço (modificada de Paillet, 1994). (B) Imagem de amplitude gerada pela fratura (linha mais escura)

Importante lembrar que as perfurações de poços quase sempre afetam a integridade das fraturas, devido à desagregação da rocha intemperizada e quebra dos minerais menos resistentes. Deste modo, a espessura relativa de uma feição indicativa de fratura na imagem gerada, pode ser correlacionada à abertura da fratura na parede do poço apenas de forma qualitativa (Paillet, 1994). A fratura pode ainda não ser contínua dentro do meio, portanto, não há uma boa correlação com a transmissividade.

Segundo Williams \& Johnson (2004), o OTV tem a vantagem de visualização direta da relação entre litologia, planos de foliação, estratificação e fraturas, ao passo que no ATV, a relação entre os aspectos litológicos e estruturais pode não ser tão clara. As fraturas podem ser reconhecidas em ambos os métodos, no entanto, caso as rochas sejam escuras, as fraturas terão maior contraste no ATV, sendo difícil sua distinção no OTV. 
As feições estruturais podem ser identificadas através de traços senoidais e a orientação de cada fratura é comumente apresentada em forma de tadpole. Os estereogramas são também utilizados para comparar e visualizar a distribuição de certo grupo ou família de fraturas em um ou mais poços.

\section{Filmagem de Poços}

A filmagem do poço consiste na introdução de uma sonda dentro do furo, orientada na vertical, na qual são acopladas uma ou mais câmeras de vídeo de alta resolução.

A captura das imagens, ajuste dos focos, velocidade de descida e rotação da câmera são controlados por um operador em superfície, que acompanha a filmagem através de um monitor. As câmeras são fixadas em base rotativa, registrando imagens de fundo do poço durante a descida ou subida do equipamento que pode ser parado a qualquer momento para registro fotográfico ou tomadas laterais, girando $360^{\circ}$ e percorrendo toda a circunferência do furo. A filmagem deve ser utilizada como complemento das perfilagens citadas.

\section{Medidor de fluxo de água (Flowmeter)}

O medidor de fluxo de água é utilizado para se obter informações a respeito do sentido e da velocidade do fluxo vertical de água dentro do furo. Medições de fluxo podem ser realizadas por sondas através de métodos mecânicos, que são mais baratos, porém menos precisos, com a utilização de traçadores químicos ou radioativos, ou ainda métodos termais que foram aprimorados ao longo do tempo, sendo estes últimos os mais confiáveis para medição de fluxo em baixas velocidades (Paillet et al., 1994).

Outro método amplamente utilizado para caracterização hidráulica de fraturas é o teste com um único obturador (packer), sendo cada vez mais substituídos ou complementados por métodos mais sensitivos e de melhor resolução como os Flowmeter (Neuman, 2005).

O Heat Pulse Flowmeter é composto por uma resistência térmica que emite um pulso de calor e por dois sensores (termistores), um localizado acima e outro localizado abaixo da resistência (figura 7), que captam possíveis variações na temperatura da água ao longo do tempo pelo pulso de calor emitido. As medições 
são realizadas com o equipamento estacionado em profundidades definidas, utilizando o calor como traçador.

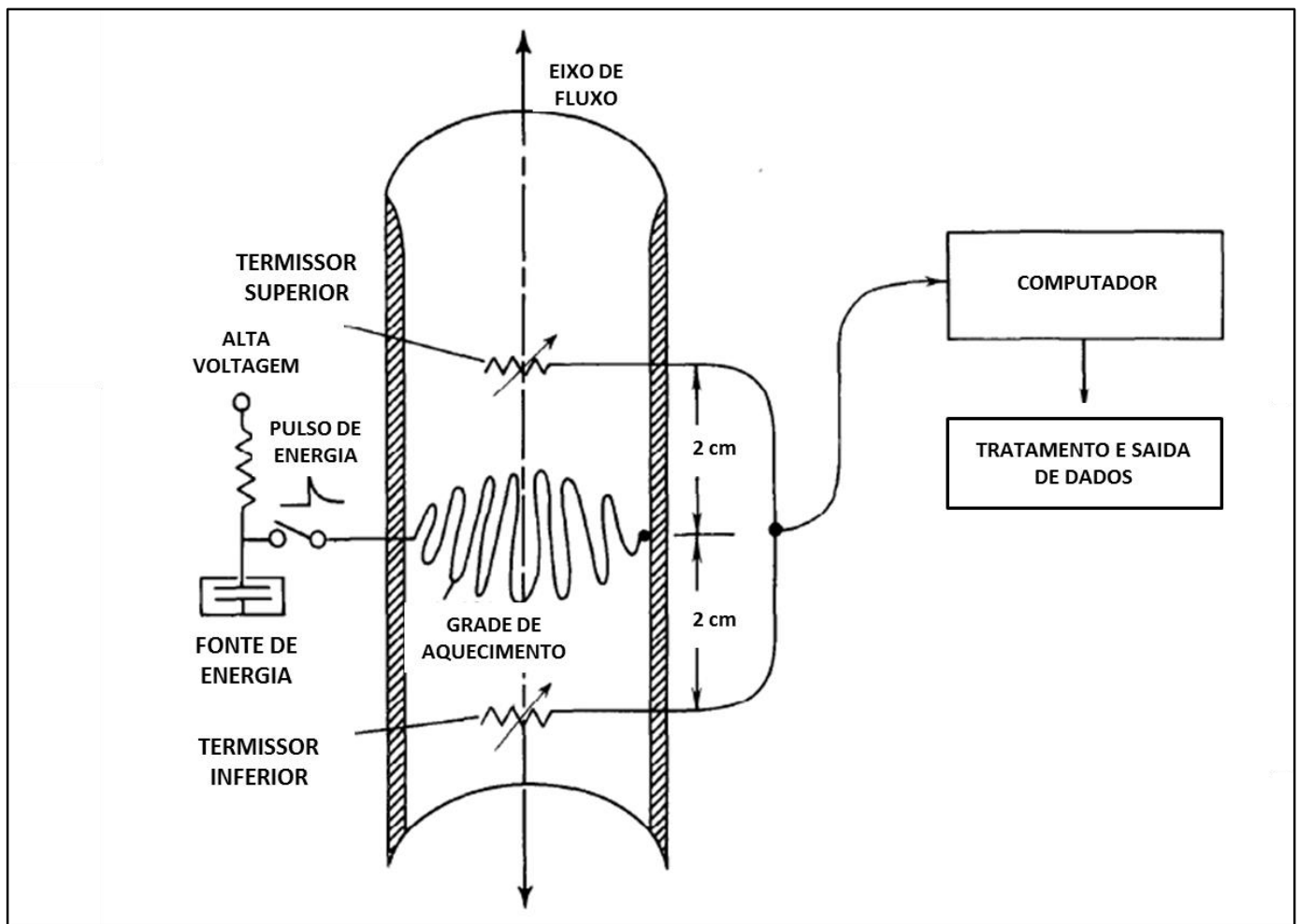

Figura 7 - Esquema de funcionamento do Flowmeter (Modificada de Hess \& Paillet, 1990)

Após a descida do equipamento na posição desejada, aguarda-se alguns minutos (5 min.) para cessar a turbulência gerada na água pela movimentação do aparelho e para o restabelecimento das condições naturais de fluxo (Hess, 1990). Caso exista o fluxo de água dentro do poço, a água aquecida pelo pulso de calor irá se movimentar no sentido do fluxo, sendo detectada pelo sensor superior ou inferior. O tempo gasto neste percurso dá uma indicação da velocidade de fluxo, sendo esta inversamente proporcional ao tempo de trânsito (quanto maior o tempo deste percurso, menor é a velocidade do fluido). Hess (1990) recomenda a realização de repetidas medições, esperando tempo suficiente entre os pulsos de disparo, até que sejam observadas três ou mais sucessivas medições com uma pequena variação. A velocidade de fluxo é então determinada pela média das últimas medições realizadas.

Os resultados são então apresentados em um gráfico que registra a variação das leituras, sendo que curvas com inflexões positivas indicam fluxo ascendente (ou seja, valores medidos no sensor de cima) e curvas com inflexões negativas indicam fluxo descendente (captada pelo sensor inferior). Em velocidades descendentes 
muito baixas, o sensor pode registrar uma resposta positiva uma vez que a água aquecida tende a flutuar devido à diferença de densidade. No entanto, esse efeito pode ser minimizado com a adequada calibração do equipamento (Hess, 1990).

Assim, as informações obtidas por cada tipo de perfilagem são complementares e, se interpretadas em conjunto, possibilitam uma maior precisão na caracterização e elaboração do modelo conceitual hidrogeológico da área, sendo fundamental para entendimento do transporte de contaminantes no meio. Uma vez que o OTV e ATV fornecem imagens orientadas, sua utilização é essencial para a caracterização das fraturas fornecendo informações críticas para posicionamento de obturadores (packers) infláveis para a realização de testes hidráulicos e monitoramentos de qualidade da água (Williams \& Johnson, 2004).

\subsubsection{Amostragem com obturadores}

Os obturadores pneumáticos, também chamado de Packers, são utilizados para isolar seções específicas dentro de um poço com o objetivo de realizar ensaios de bombeamento, monitoramento de cargas hidráulicas, identificação de fluxos naturais de água no furo aberto e a coleta de amostras de água.

O furo aberto age como um caminho preferencial de alta permeabilidade, conectando fraturas que anteriormente não estavam conectadas e levando a interpretações ambíguas dos dados químicos ou hidráulicos. O uso dos packers sela o intervalo determinado, reduzindo ou eliminando temporariamente $o$ efeito ocasionado pela mistura de água (Shapiro, 2001).

O sistema de amostragem com obturadores foi inicialmente desenvolvido e utilizado pelos pesquisadores da USGS na década de 60 (Jones, 1961, apud Holloway, 2008) e seu uso foi descrito pela Sociedade Americana de Testes e Materiais e pela Agência Americana de Proteção Ambiental sendo posteriormente aperfeiçoado (Holloway, 2008).

Os obturadores consistem basicamente em duas borrachas cilíndricas infláveis, acopladas a uma haste de aço para sustentação principal (figura 8). As borrachas funcionam como bexigas, e são infladas na profundidade desejada com a utilização de compressores de ar ou cilindros de gás, isolando o intervalo desejado. 


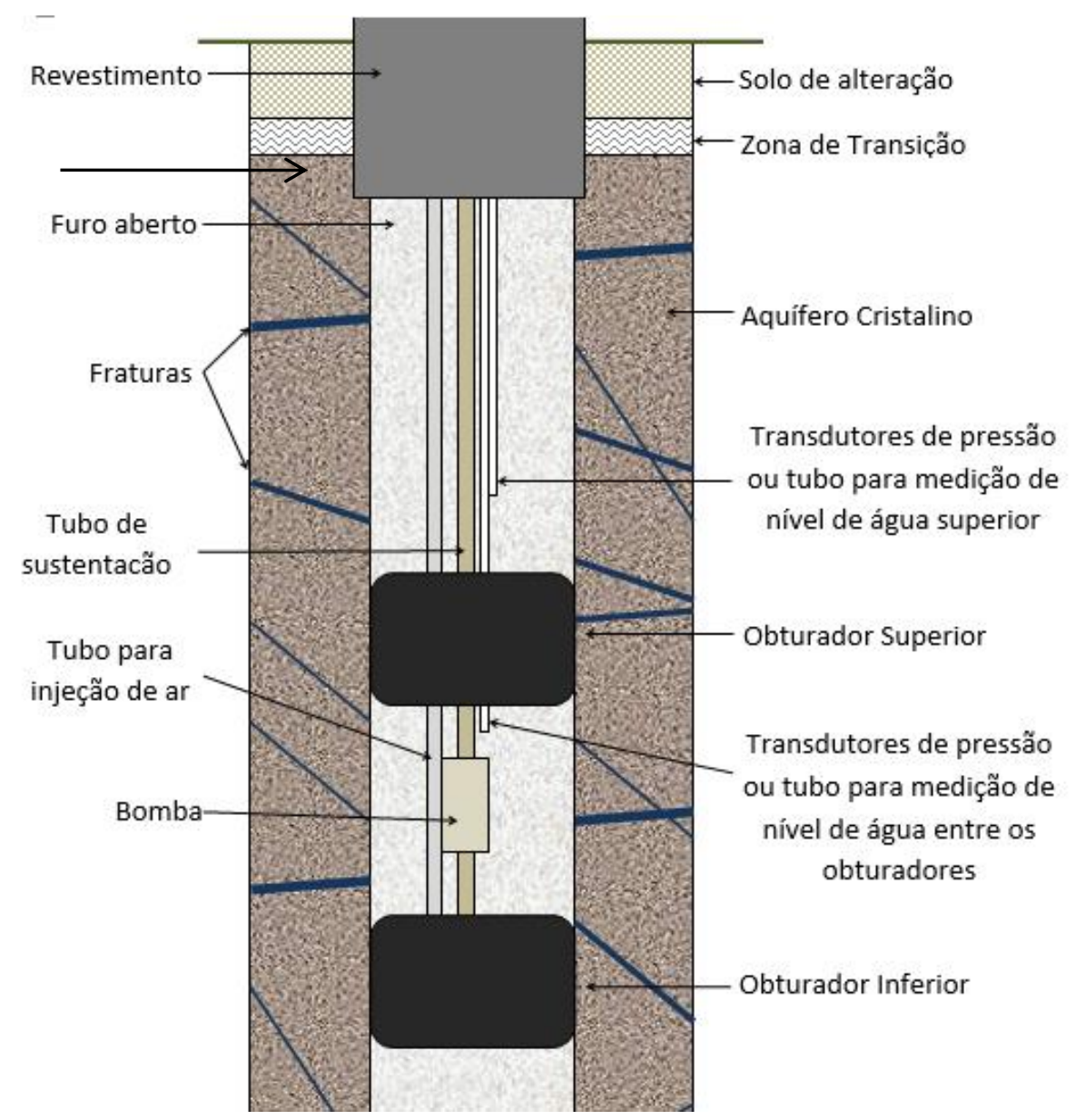

Figura 8 - Esquema de amostragem com obturadores (Modificada de Stewart, 2000)

O sistema deve contar com tubos para a passagem de ar que irá inflar os obturadores pneumáticos, transdutores de pressão fixos ou tubos que vão até a superfície e possibilitem a medição de níveis de água dentro e fora da porção isolada, além de uma seção filtrante e bomba para realização de ensaios e amostragem de água no intervalo desejado.

A pressão a ser utilizada para enchimento dos obturadores dependerá do tipo de material utilizado e diâmetro do furo que deverá ser selado. Deste modo, cada obturador é construído para utilização em um determinado diâmetro de poço, e sua construção pode ser modular, permitindo a utilização de somente um obturador, caso necessário.

Para a coleta de amostras de água e de dados confiáveis durante os testes, o sistema de injeção de gás ou ar comprimido para enchimento dos obturadores deve ser fechado e estanque, não permitindo o contato do gás com a água do furo. 
Os transdutores de pressão ou medidores de níveis de água são utilizados para monitoramento da variação de carga hidráulica dentro e fora do intervalo amostrado e devem ser avaliados em tempo real.

Durante o bombeamento, o nível de água interno, medido dentro da seção isolada pelos obturadores, pode sofrer variação (rebaixamento). No entanto, esperase que o nível de água fora dos obturadores não se altere durante os ensaios e amostragem realizados dentro do intervalo obturado. Após a estabilização da carga hidráulica, as variações de nível de água observadas fora do intervalo ensaiado podem indicar falhas na vedação do furo pelos obturadores ou nas conexões do sistema. Deste modo, é importante que as medições sejam visualizadas em tempo real, para garantir a qualidade dos dados coletados (Wahnfried, 2010).

A bomba geralmente é fixada entre os obturadores, devendo a mesma ser escolhida de acordo com os objetivos das investigações. As bombas centrífugas submersíveis com motores elétricos são mais adequadas para realização de testes de bombeamento, possibilitando a extração de água de modo contínuo, porém não são adequadas para amostragem de certos compostos, pois podem ocasionar turbulência excessiva e provocar o aquecimento da água e consequente volatilização de compostos (Wanhfried, 2010). Já as bombas de baixa vazão, ocasionam um menor distúrbio no meio e são mais adequadas para amostragem de água, porém podem não atingir vazões suficientes para permitir o rebaixamento e interpretação de dados de bombeamento.

Tendo em vista as limitações com relação à amostragem e profundidade dos equipamentos, o serviço geológico americano (USGS) criou em 2008 um novo design, aprimorando o sistema de amostragem com obturadores já existentes. $O$ chamado AFP6 Straddle-Packer System desenvolvido pelo projeto, inclui uma bomba dupla (dual pump) que possibilita o bombeamento com diferentes vazões e profundidades, uma válvula para injeção de fluido, transdutores de pressão absoluta que foram acoplados, dentre outras modificações que possibilitaram a operação em maiores profundidades (até aproximadamente 600 pés ou $183 \mathrm{~m}$ ). O sistema conta ainda com guinchos móveis e um trailer para suporte das operações de campo de longa duração.

No Brasil, a utilização dos obturadores pneumáticos vem crescendo, mas é ainda muito recente a amostragem com esse tipo de método. Em 2010, Wanhfried construiu um obturador pneumático baseado no sistema desenvolvido pelo Serviço 
Geológico Americano para a realização de testes hidráulicos e amostragem em profundidades discretas. O trabalho descreve os equipamentos utilizados, e os procedimentos para uso, reforçando a importância do uso da ferramenta em estudos de aquíferos fraturados.

\subsection{Ensaios de Permeabilidade}

Os ensaios de permeabilidade são utilizados para determinação de parâmetros específicos do intervalo definido, como condutividade e transmissividade, e podem ser realizados em laboratório ou em ensaios de campo.

Os ensaios realizados in situ possibilitam a obtenção dos parâmetros naturais do meio, que são influenciados pelas heterogeneidades presentes no local. São realizados através da perturbação nos níveis de água dentro do furo ou poço, que pode ser ocasionado pela introdução de água (infiltração), pela retirada de água (bombeamento) ou ainda pela introdução de um sólido de volume conhecido (slug tests), sendo monitoradas as alterações durante a recuperação ou rebaixamento dos níveis de água.

Os ensaios podem ser realizados à nível constante, no qual o nível de água dentro do furo é mantido em uma mesma posição durante todo o ensaio, ou a nível variável, no qual o nível de água é perturbado sendo então monitorado suas variações para retorno às condições originais.

Em aquíferos contaminados por exemplo, a escolha do tipo de ensaio a ser realizado deve levar em consideração, dentre outros fatores, os custos relacionados à destinação/tratamento da água contaminada (no caso de bombeamento) e a possível influência do ensaio no deslocamento da pluma de contaminação.

Foram desenvolvidos diferentes modelos para interpretação dos ensaios de permeabilidade, no entanto, a maior parte considera os aquíferos como homogêneos e isotrópicos, como os métodos desenvolvidos por Hvorslev (1951), Cooper et al. (1967) e Bouwer e Rice (1976), que são também utilizados para ensaios em aquíferos fraturados. No entanto, é importante ter em mente que as propriedades hidráulicas das fraturas podem variar significativamente ao longo do furo e os resultados obtidos são específicos do intervalo ensaiado. 


\section{CARACTERIZAÇÃO DA ÁREA}

A área de estudo está localizada em uma área industrial do município de Valinhos, no interior do Estado de São Paulo. A figura 9 ilustra a localização da área de estudo. As atividades ocorreram dentro da unidade industrial que opera no local desde a década de 60 .

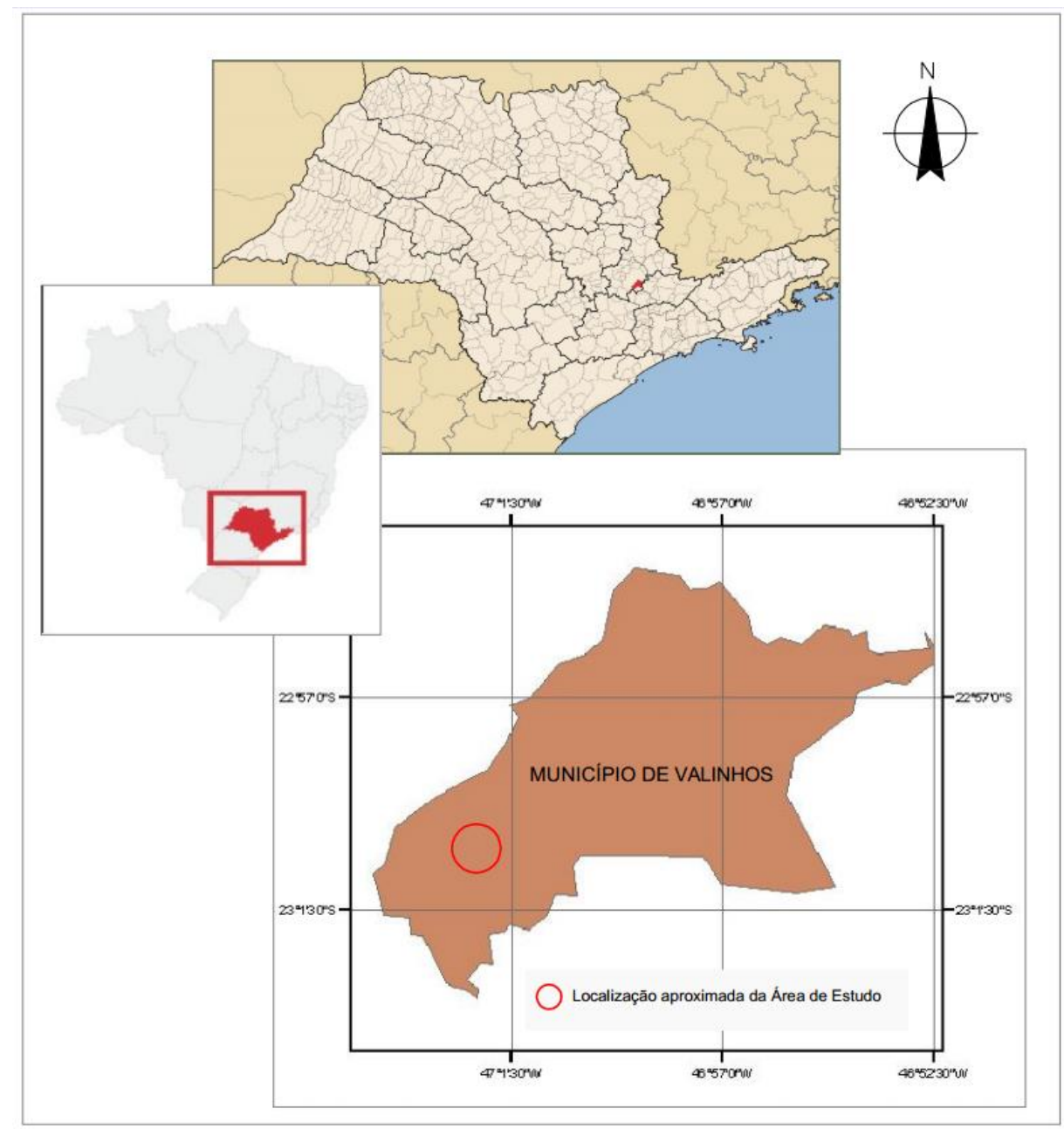

Figura 9 - Localização da área de estudo

Neste capitulo, é apresentado uma compilação dos trabalhos ambientais anteriormente realizados pela empresa Waterloo Brasil, que forneceu a base de dados para o desenvolvimento desta pesquisa.

\subsection{Geologia Regional e local}

Geologicamente a área de estudo está inserida no Complexo Socorro-Guaxupé (ou Complexo Itapira) (IG, 1993), pertencente à Província Tocantins (Almeida et al. 1977). 
Segundo Campos Neto et al. (1984) e Campos Neto (1991) a região é representada pela justaposição entre terrenos de alto grau, correspondentes ao Domínio da Nappe Socorro-Guaxupé sobre terrenos meta-vulcano-sedimentares e gnáissico-migmatíticos da Faixa Alto Rio Grande.

A Nappe Socorro-Guaxupé é interpretada como uma estrutura alóctone e representa uma seção de crosta inferior. Compreende três unidades distintas: Unidade Granulítica basal, derivada de protólitos ígneos de arco magmático, Unidade Diatexítica Intermediária, composta por gnaisses graníticos anatéticos (relacionados a fusão total de rochas) e migmatitos metaluminosos e por fim, a Unidade Migmatítica Superior, representada por um pacote de rochas metassedimentares migmatíticas (Campos Neto \& Caby, 2000). Aponta-se uma idade do Neoproterozóico para as rochas pertencentes à Nappe Socorro-Guaxupé (Campos Neto et al., 2004).

As unidades da Nappe Socorro-Guaxupé são cortadas por granitoides sin a tardi-orogênicos representados na área de estudo pela Suíte Granítica Morungaba, limitada à oeste pela Zona de Cisalhamento de Valinhos. Esta Suíte é composta por biotita granitos equigranulares a porfiríticos com idades entre 610 a $590 \mathrm{Ma}$ (Vlach, 1993).

O mapa geológico apresentado na figura 10 foi extraído de Waterloo (2011) e apresenta uma compilação dos trabalhos previamente existentes na área de interesse elaborados por CPRM, 2006; Fernandes, 1997 e Gomes, 1997. 


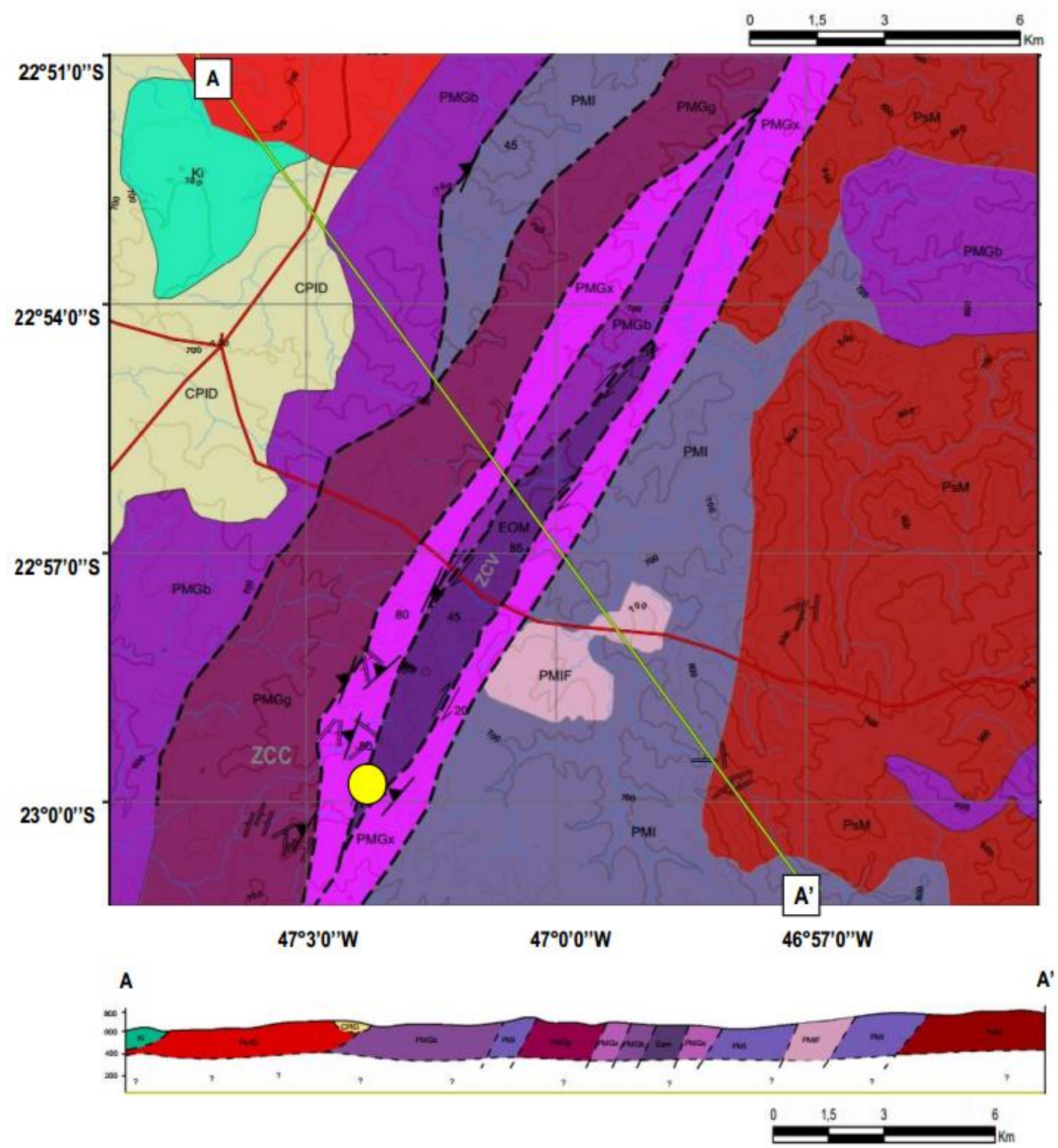

\section{Bacia do Paraná}

\section{Grupo Săo Bento}

$\mathrm{Ki}$ - Intrusivas básicas tabulares - Soleiras de diabásio faneritico, equigranular,

tria fina, estrutura maciça.

Grupo Itararé

CPID - Ritimitos e Diamictitos - Arenito, tilito, siltito, folhelho, ritmito, conglomerado e raras camadas de carvão; ambiente glácio-marinho.

Magmatismo Relacionado ao Orógeno Socorro - Guaxupé

PsJG - Granito Jaguariúna - Biotita-granito porfiritico e anfibólio granitoide

PsM - Granito Morungaba - Granito equigranular, faneritico, coloração rósea, granulometria média. Apresenta cristais idiomórficos de feldspato.

\section{Zona de Cisalhamento Valinhos}

Eom - Gnaisses miloniticos de composiçăo quartzo feldspática, biotita e titanita

\section{Complexo Socorro-Guaxupé}

\section{Unidade Migmatitica Superio}

PMGx - Gnaisses bandados com leucossoma centimétrico de textura granoblástica e mesossoma xistoso de textura lepidublástica e espessura mili a centimétrico

PMI - Gnaisses indiferenciados de coloração acizentada, equigranular a inequigranular

PMIF - Gnaisse granitóide facoidal, blastomilonitico, leucocrático de matriz média a fina intergranular, composição granitica com homblenda, biotita e pirita

\section{Unidade Migmatitica Intermediária}

PMGb - Gnaisse migmatitico de composiçâo quartzo-feldspática de coloraçăo predominantemente acinzentada.

PMGg-Rocha gnáissica, de composiçăo quartzo feldspática com milonitizaçăo local.

\section{$\sim$ Rede de Drenagem \\ 3 Medidas de Foliaçăo - Direção e \\ Seçẫo Geológica A-A Mergulho \\ Direção dos principais padrões \\ Localização da área de estudo}

Figura 10 - Mapa geológico da área de estudo Fontes: Adaptado de CPRM, 2006; Fernandes, 1997 e Gomes, 1997 (em Waterloo, 2011). 
As principais descontinuidades na região em estudo correspondem às Zonas de Cisalhamento transcorrentes dextrais de Valinhos (ZCV) e Campinas (ZCC), de direção NNE (Cavalcante et al. 1979, Fernandes, 1997). Estas zonas de caráter dúctil controlam a foliação gnáissica e milonítica das rochas do Domínio SocorroGuaxupé que apresentam direção NE a NNE com mergulhos elevados para NW e subordinadamente para SE (IG, 1993).

Segundo Instituto Geológico (1993), as rochas da região foram submetidas a quatro fases de deformação rúptil. As principais estruturas geradas correspondem a falhas transcorrentes e fraturas conjugadas, ambas de mergulhos elevados a subverticais.

Falhas rúpteis de direção WNW-ESE a NW-SE são importantes entre as Zonas de Cisalhamento de Campinas e Valinhos. Estas falhas imprimem pequenos deslocamentos nas cristas de milonitos da região além de gerar faixas extensionais que podem alojar veios de quartzo. Hidrogeologicamente, estas estruturas podem ser favoráveis ao fluxo de água subterrânea (IG, 1993).

Falhas normais de direção NNE geram na área estruturas extensivas na mesma direção e, segundo IG (1993), são capazes de armazenar e transmitir água no aquífero fraturado.

Em 2011, a empresa Waterloo Brasil realizou a interpretação fotogeológica da área na escala 1:25.000 (figura 11), levantamento geológico e execução de perfilagens geofísicas em superfície, com o objetivo de identificar e caracterizar as principais rochas e verificar a profundidade do topo rochoso na unidade, além de possíveis descontinuidades no embasamento como falhas e fraturas. 


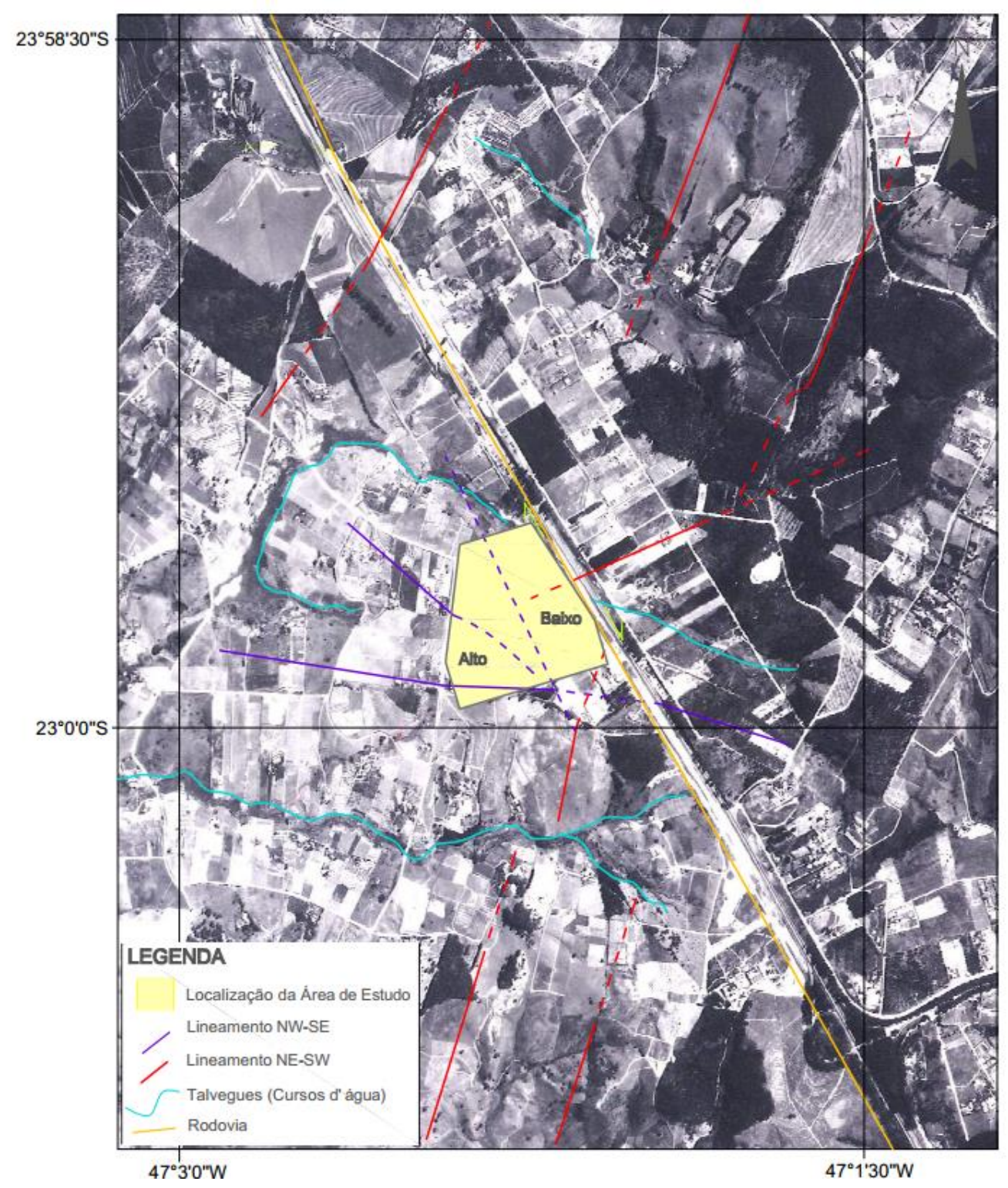

Figura 11 - Principais feições identificadas na fotointerpretação (Fonte: BASE Aerofotogrametria e Projetos Ltda, 1972)

As estruturas de cristas de morro identificadas indicaram um padrão de orientação regional paralelo aos lineamentos NE-SW, associados aos planos de foliações das rochas gnáissicas da região e paralelo à Zona de Cisalhamento de Valinhos. Além do padrão NE-SW, foi possível observar outra família impressa no relevo de direção WNW-ESE a NW-SE, que em muitos pontos abrigam talvegues e pequenos córregos, paralelos a esta direção.

O levantamento em campo da geologia da área de Valinhos e do seu entorno compreendeu a visita a 15 afloramentos (figura 12) para a coleta de dados estruturais, como medidas de foliação e de planos de falhas/ fraturas. 


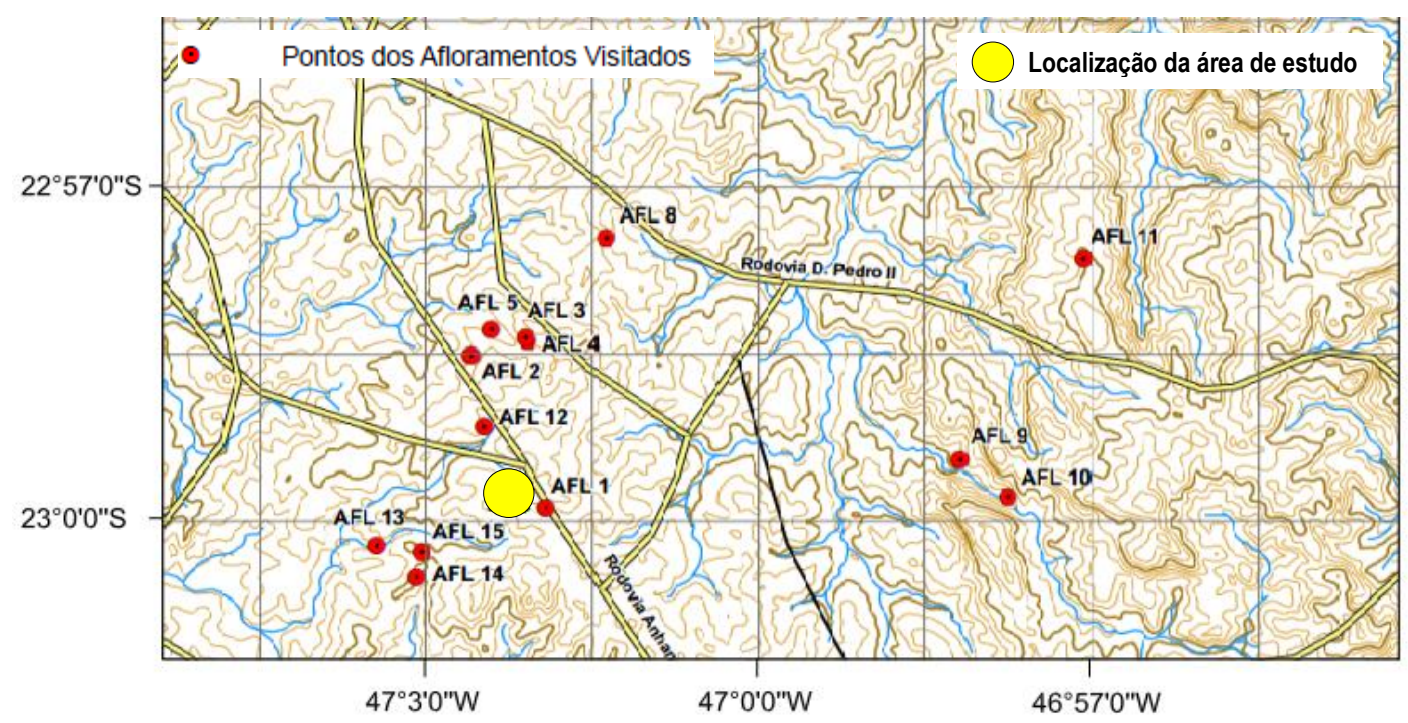

Figura 12 - Mapa com pontos de afloramentos visitados por Waterloo (2011)

As principais rochas gnáissicas aflorantes na área de Valinhos, e presente também na área de estudo, pertencem às Unidades Migmatíticas Superior e Intermediária.

A Unidade Migmatítica Superior, foi verificada nos afloramentos 01, 02, 03, 04 , 05 e 12 apresentando intercalações de bandas xistosas (já bastante alteradas) com bandas gnáissicas (grau moderado de alteração, granulação média, coloração acinzentada). Ambas litologias se apresentaram localmente milonitizadas. Foram verificadas fraturas preenchidas por quartzo e dobras de arraste na porção xistosa além de diversas descontinuidades no leucossoma do gnaisse.

Como pode ser visto nos estereogramas apresentados nas figuras 13 e 14, elaborados com base nos dados coletados nestes afloramentos, estes gnaisses apresentam plano de foliação milonítica de orientação NE-SW, gerado pela ação da Zona de Cisalhamento Valinhos, principal estrutura tectônica da região.

As fraturas observadas nestes gnaisses são paralelas aos planos de foliação. Apresentam caráter distensivo e que apresentam, no geral, preenchimento mineral formando veios de quartzo leitoso e veios pegmatíticos compostos por quartzo, plagioclásio e minerais como turmalina e muscovita.

Em nenhum afloramento foi visualizada a percolação de água nas descontinuidades destas rochas. No entanto, trabalhos científicos sobre a dinâmica do aquífero fraturado da região (IG, 1993) relacionam as fraturas de direção NE-SW como as principais estruturas condutoras de água nos gnaisses em estudo. Além disto há diversos poços tubulares profundos instalados na região que extraem água 
do aquífero cristalino comprovando a existência de água nas descontinuidades destas rochas.

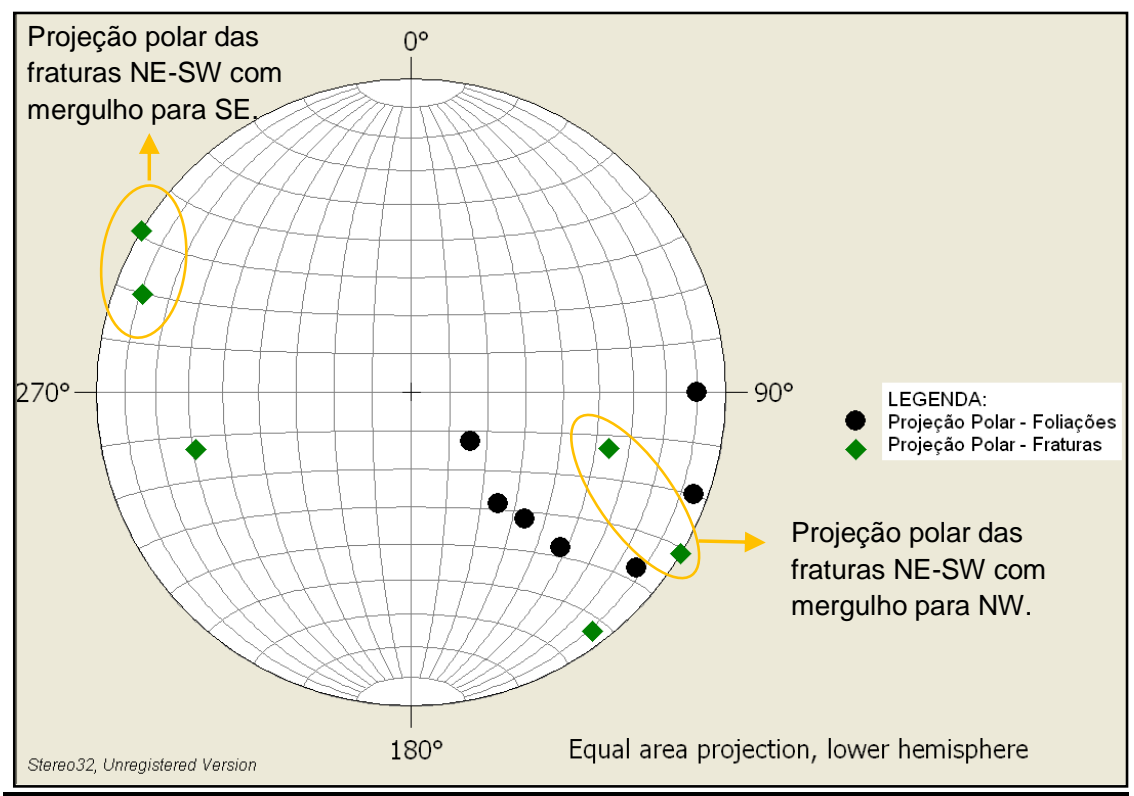

Figura 13 - Projeções polares dos planos de foliação e de fraturamento nos gnaisses xistosos da unidade migmatítica superior

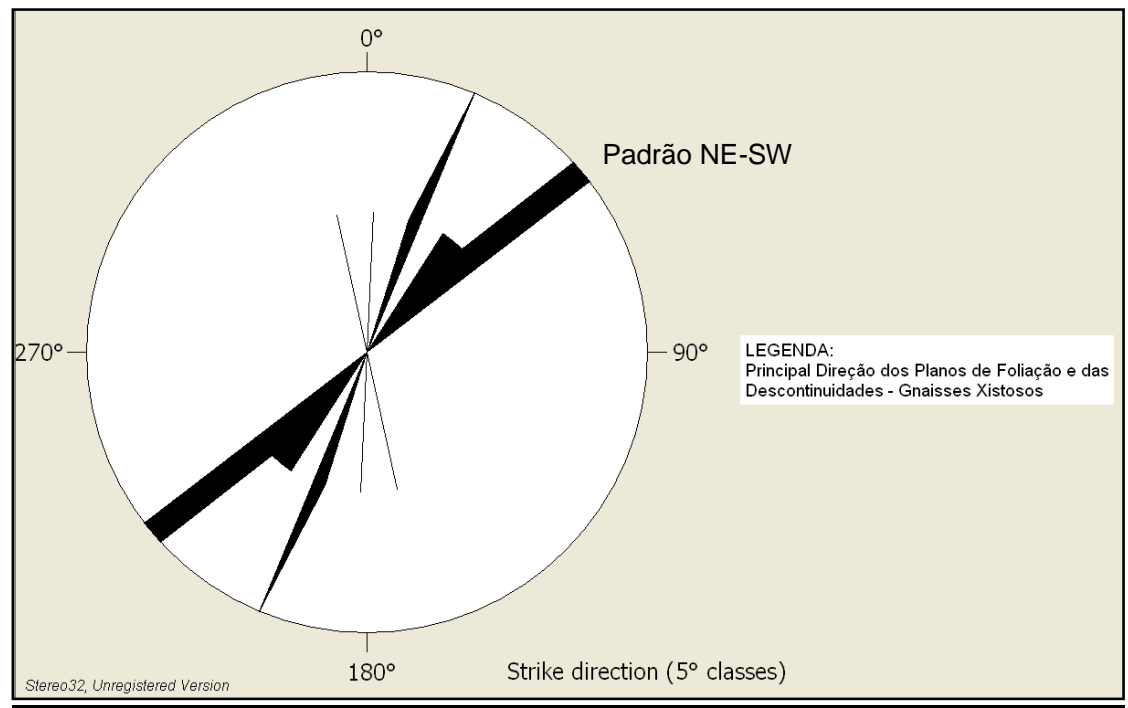

Figura 14 - Rosácea dos dados estruturais dos gnaisses xistosos mostrando as principais direções dos planos de foliação e de fraturamento

A Unidade Migmatítica Intermediária identificada nos pontos 08, 13, 14 e 15 foram descritas como gnaisses migmatíticos, apresentando porções leucossomáticos de textura granoblástica representada por cristais de quartzo e plagioclásio predominantemente. As porções mesossomáticas são caracterizadas 
por biotita e estruturalmente estão presentes fraturas/fendas de tração preenchidas por quartzo.

As rochas pertencentes à Unidade Migmatítica Intermediária são gnaisses graníticos com plano de foliação de direção NE-SW. Diferente dos gnaisses xistosos da Unidade Superior, as fraturas deste litotipo são de pequeno porte, apresentam preenchimento de cristais de quartzo e direção predominante NW-SE (figuras 15 e 16).

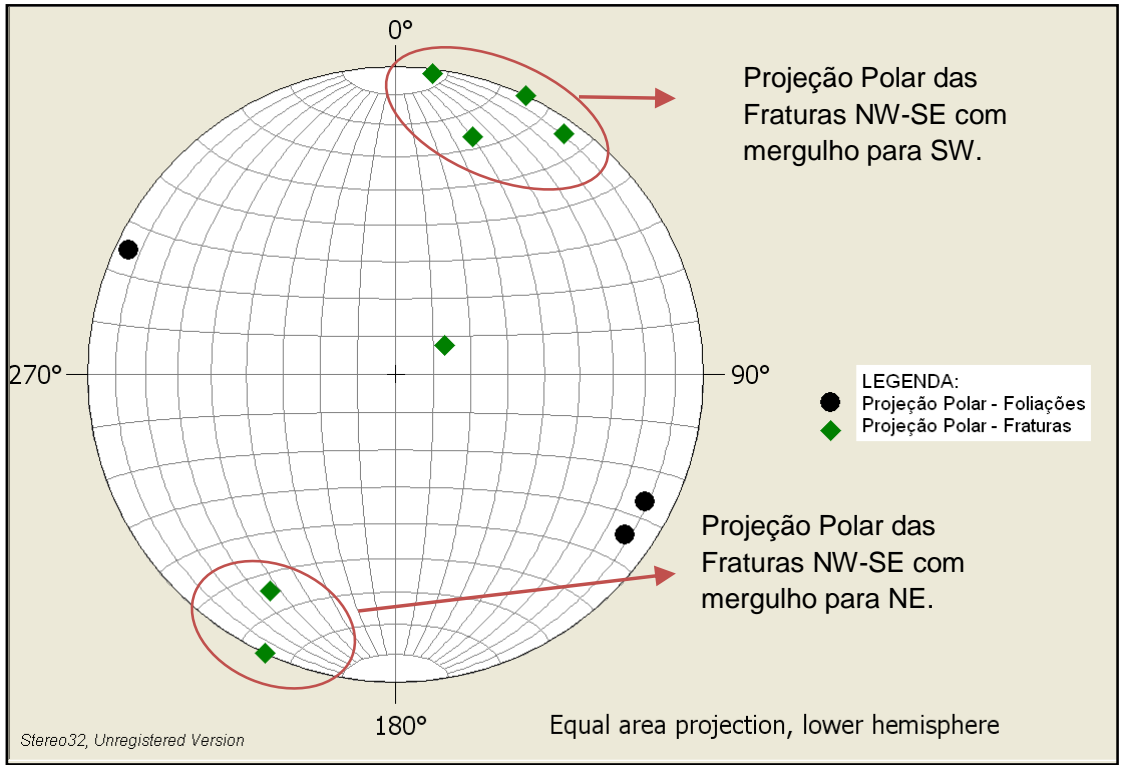

Figura 15 - Projeções polares dos planos de foliação e de fraturamento nos gnaisses graníticos da unidade migmatítica intermediária

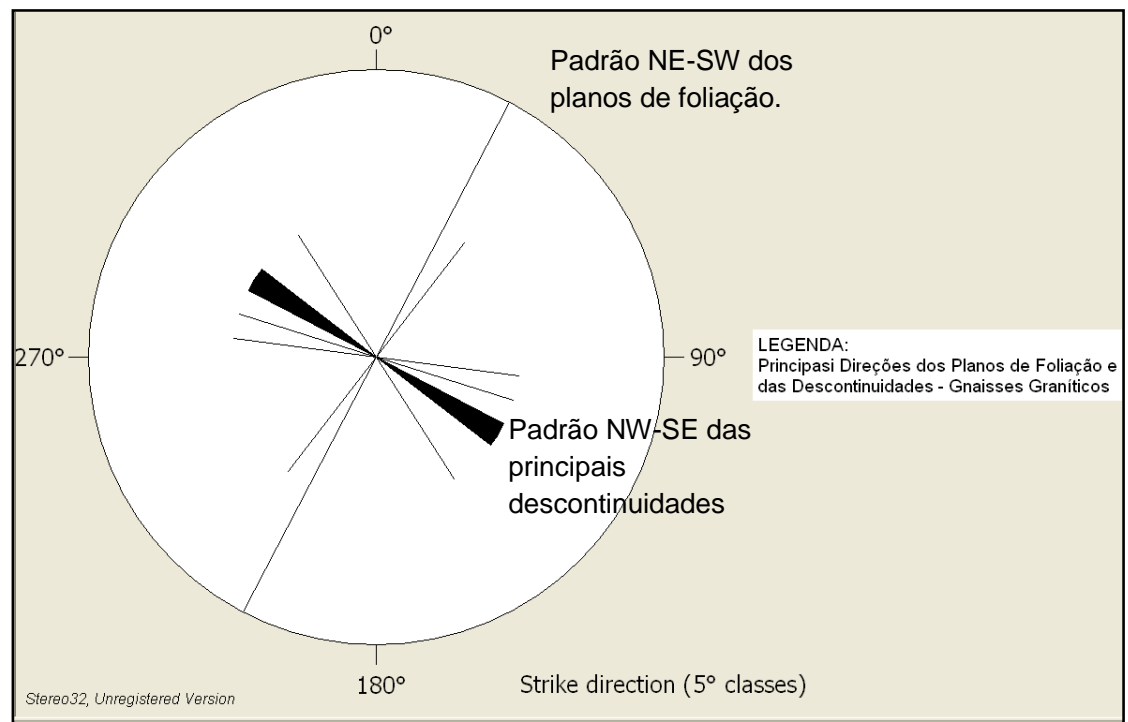

Figura 16 - Rosácea dos dados estruturais dos gnaisses graníticos mostrando as principais direções dos planos de foliação e de fraturamento 
Nos gnaisses, não foi observada percolação de água nas fraturas, estando todas preenchidas por quartzo leitoso e material pegmatítico. No entanto, o fato de existirem diversos poços tubulares profundos na área de estudo e no entorno que extraem água do aquífero cristalino é uma confirmação de que as fraturas e demais descontinuidades existentes em profundidade nas rochas gnássicas possuem capacidade de armazenar e transmitir água.

Ainda no entorno observam-se os granitos da Suíte Morungaba (afloramentos 10 e 11), rochas intrusivas (diabásios) pertencentes à bacia do Paraná, e depósitos aluvionares recentes do Quaternário que estão presentes nas margens dos rios e córregos da região.

Neste mesmo trabalho, foi realizada a geofísica de superfície empregando as técnicas de Caminhamento Elétrico (CE), e Sondagem Elétrica Vertical (SEV). De uma maneira geral, os perfis de resistividade revelaram três padrões distintos relacionados com os diferentes litotipos presentes na área.

O primeiro padrão é representado pelas camadas de aterro e de solo siltoargiloso presentes em toda a área de estudo com espessuras que variam de 2,0 a 5,0 metros aproximadamente e com valores de resistividade em torno de 150 Ohm.m. O segundo padrão apresenta valores entre 200 e 1500 Ohm.m e representa o solo de alteração de rocha com espessuras variando entre 10,0 a 35,0 metros. O terceiro e último padrão está relacionado com o saprólito e a porção sã da rocha gnáissica presente em área, caracterizado por valores elevados de resistividade superiores a 1500 Ohm.m, como mostra o mapa de resistividade apresentado na figura 17, ocorrendo em profundidades mais rasas na porção oeste da unidade industrial (entre 16,0 e 23,0 metros aproximadamente) e mais profundas no centro e porção sudeste da área. 


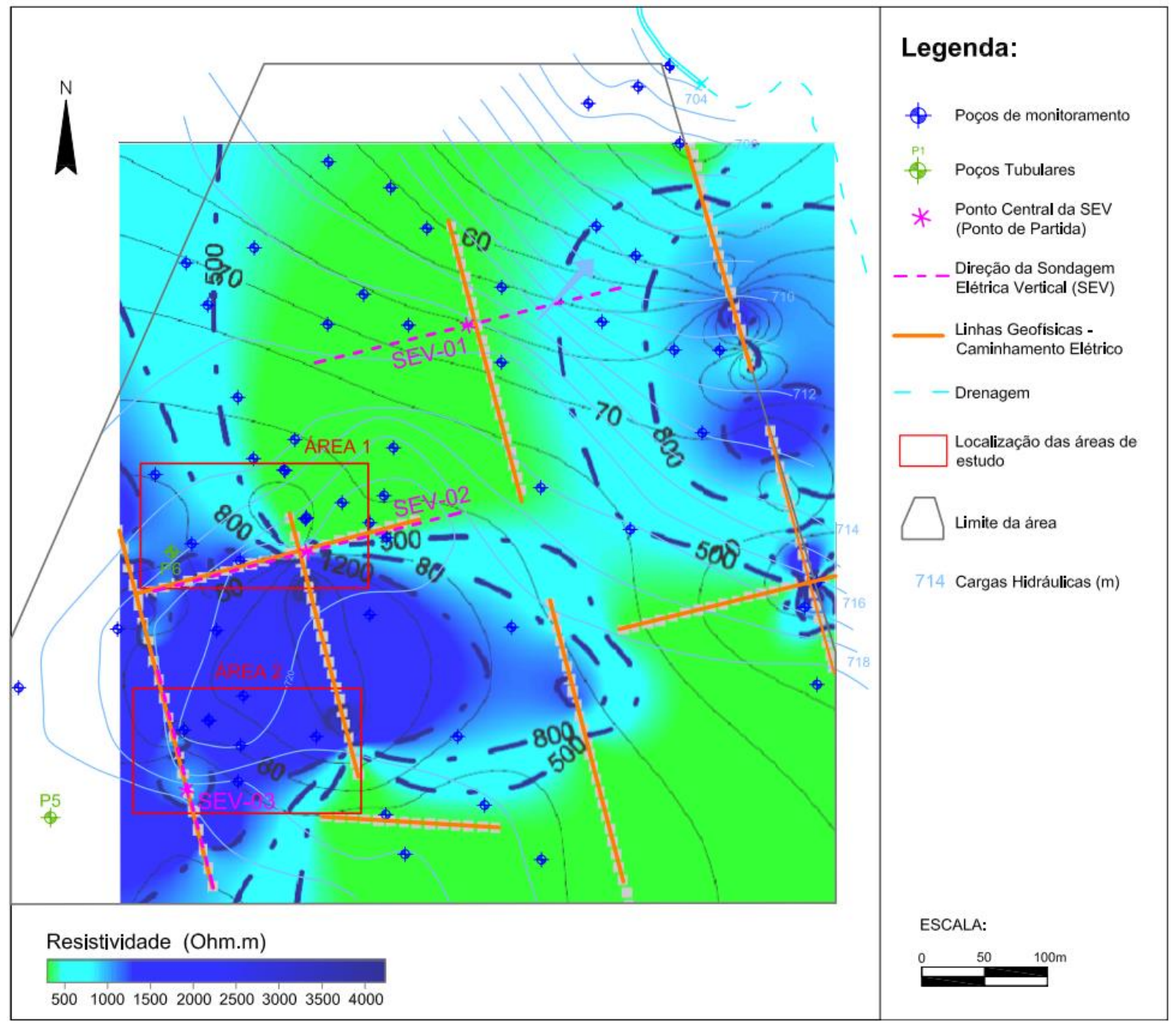

Figura 17 - Mapa de variação de resistividade. Valores elevados de resistividade estão associados à presença da rocha sã em porções mais próximas da superfície do terreno.

De acordo com os trabalhos anteriores de sondagens realizados na área pela Waterloo Brasil (Waterloo, 2011), e considerando a classificação de solo proposta por Vaz (1996), localmente foram observados os seguintes materiais:

- Solo Eluvial: Homogêneo e isotrópico, apresenta espessura entre 1,0 e 10,0 metros e é composto por material argilo-siltoso de coloração marrom avermelhada. Em alguns pontos, foi verificada uma camada de aterro com porções arenosas sobre este horizonte, confirmando a modificação da topografia original do terreno;

- Solo de Alteração: Heterogêneo e anisotrópico, composto por material siltoargiloso a silto-arenoso, com presença marcante de minerais micáceos e cristais de quartzo e coloração variada. A espessura desta camada varia dentro da unidade. Na porção leste ela atinge profundidades em torno de 35,0 
metros podendo se estender até 72,0 metros, conforme dados extraídos dos poços tubulares profundos. Cabe ressaltar que em profundidades mais rasas a alteração da rocha é mais significativa. Já na porção oeste da unidade industrial o solo de alteração de rocha é menos espesso, sendo a interface da alteração para o topo rochoso entre 16,0 e 34,0 metros aproximadamente. 0 aquífero freático da área de estudo é representada por este solo de alteração;

- Rochas gnáissicas pertencentes ao Complexo Varginha-Guaxupé de coloração acinzentada, granulometria média a fina e apresentando em sua composição biotita, quartzo e feldspato. Conforme verificado nas informações extraídas dos perfis das sondagens executadas na área, o topo rochoso está presente em profundidades rasas na porção oeste da área, e mais profundo na porção leste.

\subsection{HIDROGEOLOGIA}

Dentro do contexto hidrogeológico regional, ocorrem dois aquíferos: o freático (poroso), que apresenta como matriz a camada de solo subsuperficial e o manto de alteração das rochas do embasamento cristalino; e o aquífero cristalino (fraturado), constituído pelos gnaisses da Unidade Migmatítica do Domínio Socorro-Guaxupé e pelas rochas graníticas da Suíte Morungaba. Desta forma, a água subterrânea está presente no manto de alteração (aquífero poroso) e nas descontinuidades de caráter rúptil que imprimem uma porosidade secundária, por fraturamento.

O manto de alteração é resultante do intemperismo das rochas basais, sendo constituído por material arenoso a argiloso em função da composição mineralógica da rocha sã. $\mathrm{Na}$ área de estudo o manto de alteração apresenta comportamento de aquífero livre e espessura entre 10 e 40 metros, podendo chegar a 50 metros (Waterloo, 2011).

O aquífero freático local é heterogêneo e anisotrópico, apresentando porosidade intergranular e geometria definida com base no arranjo das camadas geológicas constituintes. Este aquífero caracteriza-se como livre, não havendo diferenças significativas de cargas hidráulicas entre os poços de monitoramento instalados a 3,88 e 36,87 metros de profundidade (Waterloo, 2011).

No aquífero raso, o fluxo de água é governado principalmente por meio da porosidade primária intergranular e recarregado pela infiltração direta de água de chuva a partir da superfície, por toda a área. 
Os valores de condutividade hidráulica obtidos variam de $1,29.10^{-7}$ a $4,28.10^{-7}$ $\mathrm{m} / \mathrm{s}$ (Waterloo, 2011) e caracterizam a matriz silto-argilosa do aquífero em estudo. A profundidade do nível de água medida entre os poços monitorados no período seco variou de 2,04 a 22,64 metros.

O sentido preferencial de fluxo da água subterrânea do aquífero raso apresenta uma componente predominante para nordeste-noroeste, em direção ao córrego localizado no limite norte da unidade industrial. Na porção central da área, o fluxo apresenta características radiais associadas à topografia da região, conforme pode ser observado nas figuras 18 e 19.

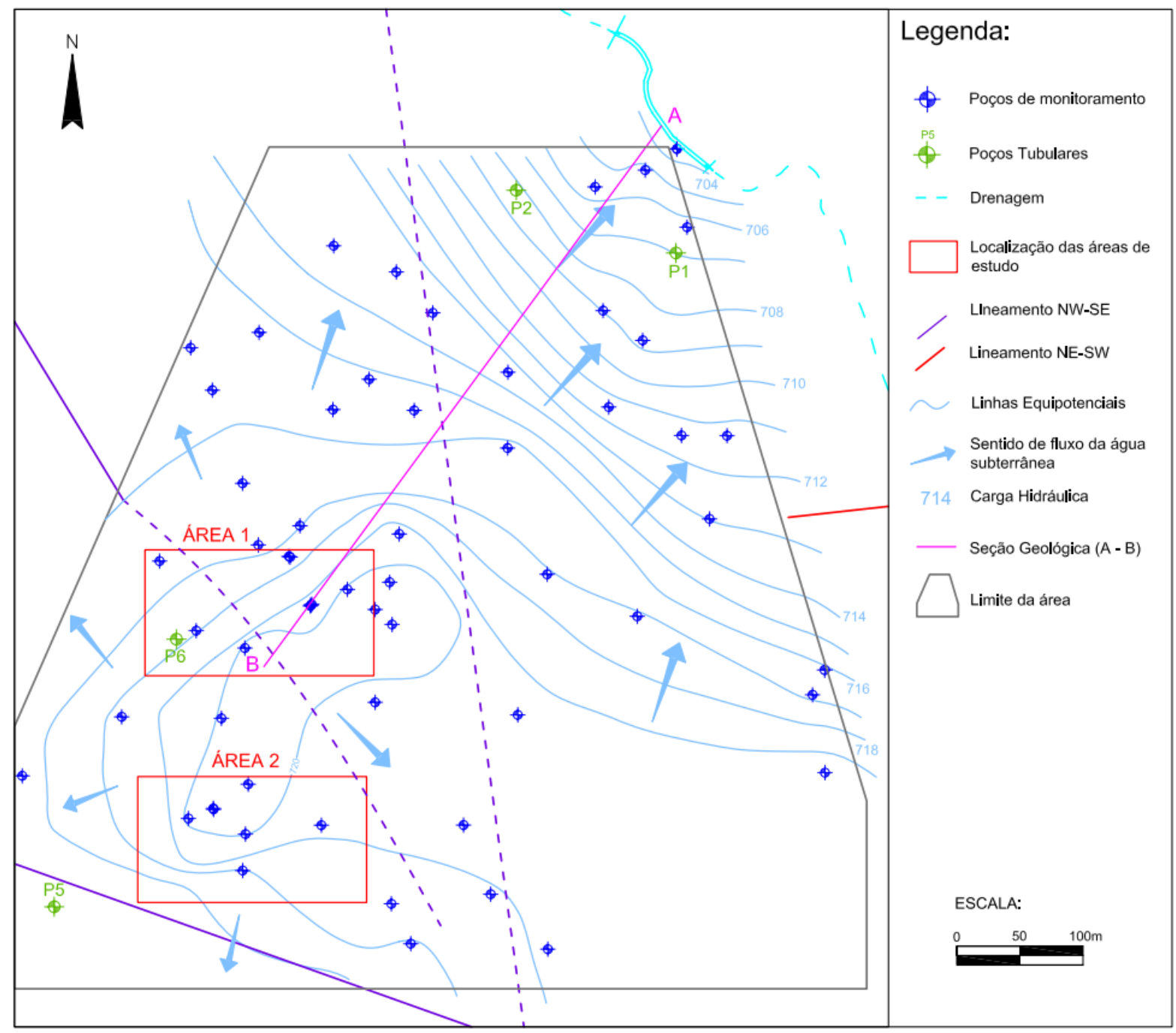

Figura 18 - Mapa potenciométrico do aquífero raso (adaptado de Waterloo, 2011) 


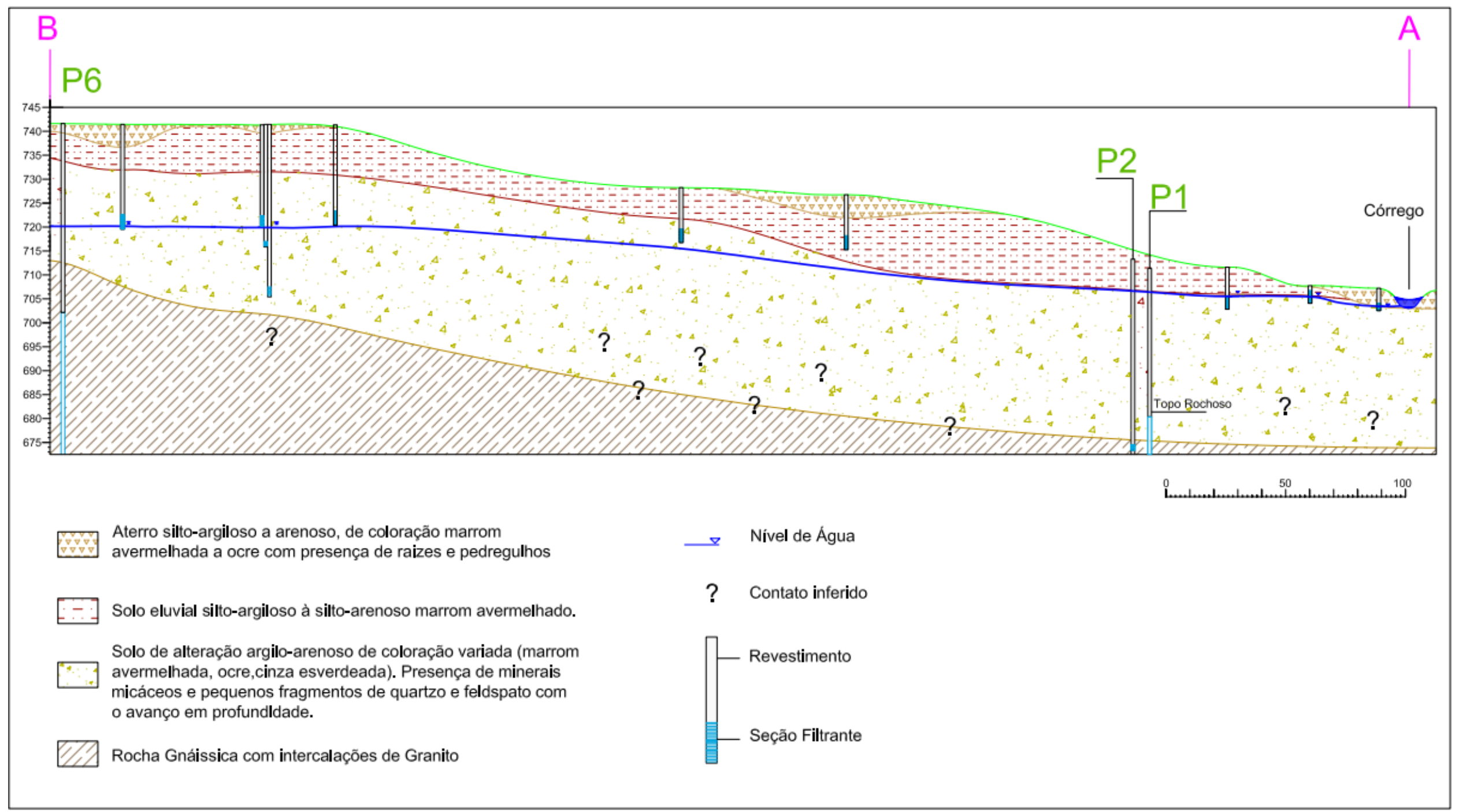

Figura 19 - Seção geológica e nível de água 
$\mathrm{Na}$ área de estudo, as rochas do aquífero cristalino ou fraturado são caracterizadas pela foliação gnáissica e milonítica de direção NNE com mergulhos acentuados, no geral para NW. As descontinuidades favoráveis ao fluxo de água são as falhas rúpteis de direção NE a ENE e NNE presentes nas rochas posicionadas a oeste das Zonas de Cisalhamento de Campinas (ZCC) e entre as Zonas de Cisalhamento de Valinhos (ZCV) e Campinas. Já nos gnaisses e nos granitos a leste da ZCV, as estruturas de caráter distensivo apresentam direção oposta: NW, WNW e NNW. O caráter heterogêneo e descontínuo predominantemente fissurado imprime um fluxo localizado refletindo em valores de nível d'água irregulares, o que dificulta o traçado de linhas potenciométricas (IG, 1993).

\subsection{Caracterização da Contaminação}

As investigações ambientais na área tiveram início em 2006, com a identificação das áreas potencialmente contaminadas, sendo posteriormente realizadas as atividades de investigações Confirmatória, Detalhada e Avaliação de Risco à Saúde Humana, conforme preconiza os procedimentos de gerenciamento de áreas contaminadas (CETESB, 2001). Foram realizadas campanhas de monitoramentos semestrais de água subterrânea, além de estudos geológicos e investigação do aquífero fraturado.

Os organoclorados eram utilizados como desengraxante na limpeza de peças, equipamentos e eventualmente piso impregnado com óleo. A contaminação da água subterrânea está relacionada, portanto, ao manuseio inadequado do produto no passado, não sendo possível identificar uma única fonte primária de contaminação, visto que essas atividades aconteciam em diferentes locais na fábrica.

O principal produto utilizado na unidade era o chamado Chloroethene, que apresentava o composto 1,1,1-tricloroetano em $96,5 \%$ de sua composição. No entanto, outros clorados com características de limpeza semelhantes podem ter sido utilizados durante esse tempo. Ressalta-se que desde 1994 o uso dos solventes foi banido na unidade e substituído por desengraxantes alcalinos.

A área de estudo apresenta dois focos distintos de contaminação por compostos organoclorados no aquífero raso, denominado neste estudo de Área $1 \mathrm{e}$ Área 2, conforme apresentado na figura 20. 


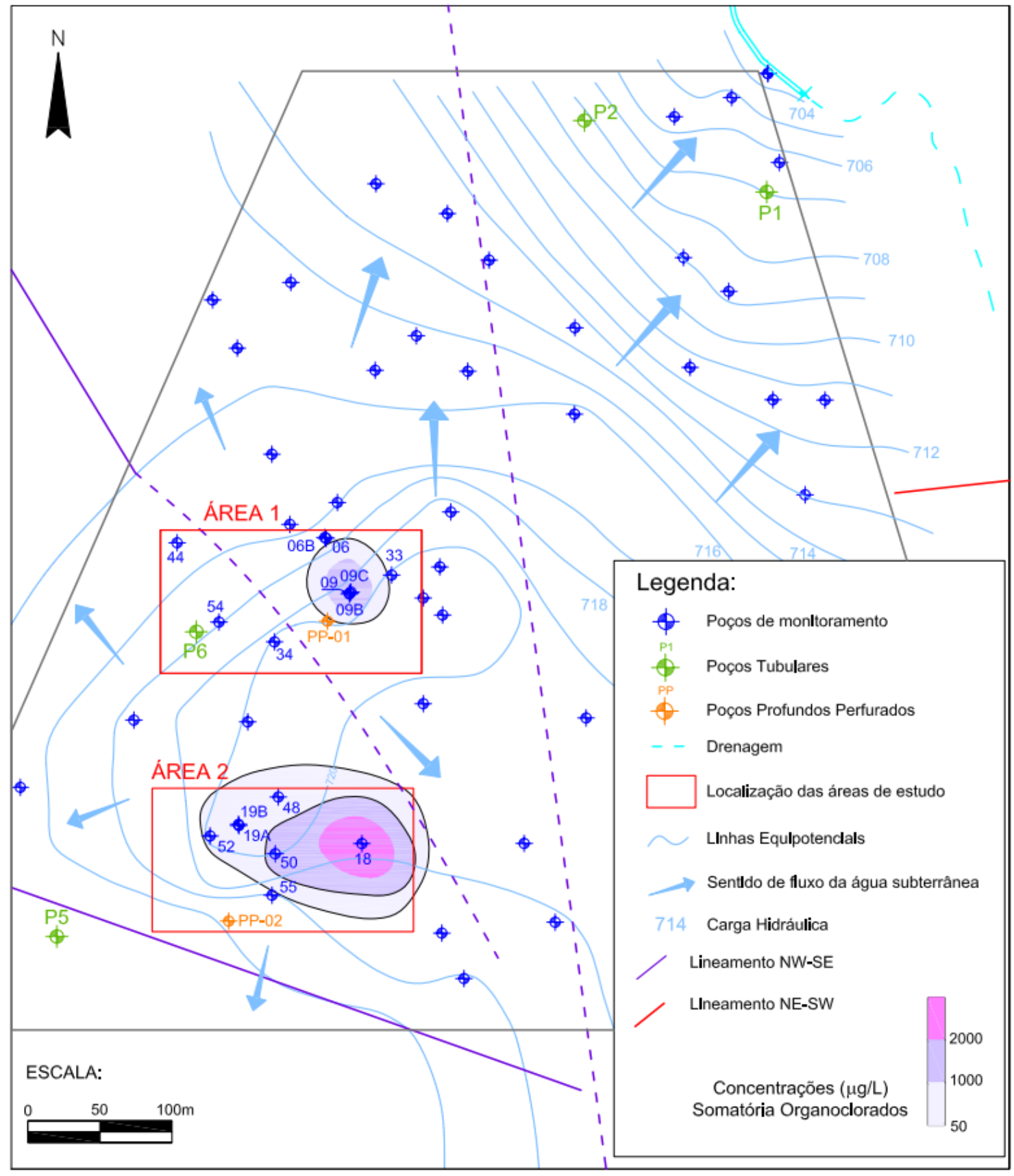

Figura 20 - Mapa de isoconcentração da somatória dos compostos organoclorados no aquífero raso. Abril 2014. (Waterloo, 2011)

A fim de caracterizar a contaminação na água subterrânea, a Waterloo realizou a instalação de um total de 59 poços de monitoramento convencionais no aquífero freático, distribuídos por toda a área industrial. Tendo em vista a densidade da maioria dos compostos organoclorados e a possibilidade de migração dos contaminantes dissolvidos por potenciais naturais descendente de fluxo de água, foram instalados poços em porções rasas, intermediárias e profundas do aquífero freático para avaliação da migração vertical da contaminação. 
Historicamente, os compostos organoclorados tetracloroeteno (PCE), tricloroeteno (TCE), cis-1,2-dicloroeteno (cis-1,2-DCE), trans-1,2-dicloroeteno (trans1,2-DCE),1,1-dicloroeteno (1,1-DCE), 1,1-dicloroetano e cloreto de vinila (CV) foram identificados na água subterrânea. Os resultados de amostras coletadas no trio multinível instalado, mostra que a contaminação atingiu o poço mais profundo instalado no topo rochoso. As cargas hidráulicas dos poços multiníveis instalados no aquífero raso não apresentaram uma variação significativa, não sendo possível estabelecer uma relação de fluxo vertical.

$\mathrm{Na}$ Área 1, predominam concentrações de compostos mais degradados como cis-1,2-dicloroeteno e cloreto de vinila. Concentrações de tricloroeteno são observadas no nível mais profundo do aquífero. Já na Área 2, o tricloroeteno apresenta a maior concentração e distribuição em área e as concentrações de compostos mais degradados, como cis-1,2-dicloroeteno e cloreto de vinila, não são expressivas. São observadas ainda concentrações de tetracloroeteno, 1,1dicloroeteno e 1,2-dicloroetano.

Ao longo do tempo não são observadas grandes variações das concentrações, no entanto a Área 1 apresenta tendência de redução, principalmente no nível mais profundo (09C). Na Área 2 no geral são observados aumentos nas concentrações. A tabela 3 apresenta os resultados de VOC (Compostos Orgânicos Voláteis) acima dos valores orientadores dos principais poços, considerando as três últimas campanhas de monitoramento. 
Tabela 3 - Resultados de compostos orgânicos clorados nos poços do aquífero raso nas últimas três campanhas de monitoramento.

\begin{tabular}{|c|c|c|c|c|c|c|c|c|c|c|c|c|}
\hline \multirow{3}{*}{ Parâmetros } & \multirow{3}{*}{ Unidade } & \multicolumn{9}{|c|}{ ÁREA 1} & \multirow{3}{*}{$\begin{array}{l}\text { Portaria } \\
n^{\circ} 2.914\end{array}$} & \multirow{3}{*}{$\begin{array}{c}\text { CETESB } \\
2014 \\
\mathrm{LI}\end{array}$} \\
\hline & & \multicolumn{3}{|c|}{$09 \mathrm{~A}$} & \multicolumn{3}{|c|}{$09 \mathrm{~B}$} & \multicolumn{3}{|c|}{$09 \mathrm{C}$} & & \\
\hline & & $a b r / 13$ & nov/13 & $\mathrm{abr} / 14$ & $\mathrm{abr} / \mathbf{1 3}$ & nov/13 & $a b r / 14$ & $\mathrm{abr} / 13$ & nov/13 & $\mathrm{abr} / 14$ & & \\
\hline Tetracloroeteno & $\mu g / L$ & 1,7 & 4,2 & \multirow{8}{*}{$\begin{array}{l}\stackrel{8}{0} \\
\text { w } \\
\circ \\
\stackrel{0}{0} \\
0\end{array}$} & $<1,00$ & 1,2 & 4,1 & 7,4 & 3 & 1,3 & 40 & 40 \\
\hline Tricloroeteno & $\mu g / L$ & 12 & 13 & & 8,3 & 8,8 & 22 & 39 & 22 & 5,6 & 20 & 20 \\
\hline 1,2-Dicloroeteno (cis+trans) & $\mu g / L$ & 3.169 & 2.316 & & 1.123 & 1.497 & 1.167 & 2.490 & 1.778 & 277,5 & $50^{(1)}$ & $50^{(1)}$ \\
\hline 1,1-Dicloroeteno & $\mu \mathrm{g} / \mathrm{L}$ & 32 & 29 & & 23 & 21 & 40 & 80 & 48 & 6,5 & 30 & 30 \\
\hline Cloreto de Vinila & $\mu g / L$ & 58 & 26 & & 25 & 20 & $<1,00$ & 3,5 & 1,3 & 2,3 & 2 & 2 \\
\hline 1,1,1-Tricloroetano & $\mu \mathrm{g} / \mathrm{L}$ & 3,3 & 2,6 & & $<1,00$ & 1,3 & $<1,00$ & $<1,00$ & $<1,00$ & $<1,00$ & - & 2000 \\
\hline 1,1-Dicloroetano & $\mu g / L$ & 850 & 618 & & 422 & 481 & 634 & 1370 & 920 & 77 & - & 53 \\
\hline 1,2-Dicloroetano & $\mu g / L$ & 3,8 & 4,4 & & 3,5 & 5,7 & $<1,00$ & 9,9 & 6,1 & $<1,00$ & 10 & 10 \\
\hline SOMATÓRIA VOC & & $4.130,1$ & $3.013,5$ & - & $1.604,8$ & $2.035,9$ & $1.867,4$ & $3.999,8$ & $2.778,1$ & 370,2 & & \\
\hline
\end{tabular}

\begin{tabular}{|c|c|c|c|c|c|c|c|c|c|c|c|c|}
\hline \multirow{3}{*}{ Parâmetros } & \multirow{3}{*}{ Unidade } & \multicolumn{9}{|c|}{ ÁREA 1} & \multirow{3}{*}{$\begin{array}{l}\text { Portaria } \\
n^{\circ} 2.914\end{array}$} & \multirow{3}{*}{$\begin{array}{c}\text { CETESB } \\
2014 \\
\text { LI }\end{array}$} \\
\hline & & \multicolumn{3}{|c|}{$06 \mathrm{~B}$} & \multicolumn{3}{|c|}{33} & \multicolumn{3}{|c|}{34} & & \\
\hline & & $a b r / 13$ & nov/13 & $a b r / 14$ & $a b r / 13$ & nov/13 & $\mathrm{abr} / 14$ & $a b r / 13$ & nov/13 & $a b r / 14$ & & \\
\hline Tetracloroeteno & $\mu g / L$ & $<1,00$ & $<1,00$ & $<1,00$ & 7,8 & 3,7 & \multirow{8}{*}{$\begin{array}{l}\text { O } \\
\text { w } \\
\circ \\
\stackrel{8}{0} \\
0\end{array}$} & $<1,00$ & $<1,00$ & $<1,00$ & 40 & 40 \\
\hline Tricloroeteno & $\mu \mathrm{g} / \mathrm{L}$ & 4,4 & 2,4 & $<1,00$ & 5,2 & 2 & & $<1,00$ & $<1,00$ & $<1,00$ & 20 & 20 \\
\hline 1,2-Dicloroeteno (cis+trans) & $\mu g / \mathrm{L}$ & 5 & 3,3 & $<1,00$ & 37 & 6,9 & & $<1,00$ & $<1,00$ & $<1,00$ & $50^{(1)}$ & $50^{(1)}$ \\
\hline 1,1-Dicloroeteno & $\mu \mathrm{g} / \mathrm{L}$ & 10 & $<1,00$ & $<1,00$ & 69 & 2,9 & & $<1,00$ & $<1,00$ & $<1,00$ & 30 & 30 \\
\hline Cloreto de Vinila & $\mu g / \mathrm{L}$ & $<1,00$ & $<1,00$ & $<1,00$ & $<1,00$ & $<1,00$ & & $<1,00$ & $<1,00$ & $<1,00$ & 2 & 2 \\
\hline 1,1,1-Tricloroetano & $\mu g / \mathrm{L}$ & $<1,00$ & $<1,00$ & $<1,00$ & $<1,00$ & $<1,00$ & & $<1,00$ & $<1,00$ & $<1,00$ & - & 2000 \\
\hline 1,1-Dicloroetano & $\mu g / L$ & $<1,00$ & 5,5 & 1,3 & 4,5 & 13 & & $<1,00$ & $<1,00$ & $<1,00$ & - & 53 \\
\hline 1,2-Dicloroetano & $\mu \mathrm{g} / \mathrm{L}$ & $<1,00$ & $<1,00$ & $<1,00$ & $<1,00$ & $<1,00$ & & $<1,00$ & $<1,00$ & $<1,00$ & 10 & 10 \\
\hline SOMATÓRIA VOC & & 19,4 & 11,2 & 1,3 & 123,5 & 28,5 & - & $<1$ & $<1$ & $<1$ & & \\
\hline
\end{tabular}

\begin{tabular}{|c|c|c|c|c|c|c|c|c|c|c|c|c|}
\hline \multirow{3}{*}{ Parâmetros } & \multirow{3}{*}{ Unidade } & \multicolumn{9}{|c|}{ ÁREA 2} & \multirow{3}{*}{$\begin{array}{l}\text { Portaria } \\
n^{\circ} 2.914\end{array}$} & \multirow{3}{*}{$\begin{array}{c}\text { CETESB } \\
2014 \\
\text { LI }\end{array}$} \\
\hline & & \multicolumn{3}{|c|}{18} & \multicolumn{3}{|c|}{$19 \mathrm{~B}$} & \multicolumn{3}{|c|}{48} & & \\
\hline & & $a b r / 13$ & nov/13 & $a b r / 14$ & $a b r / 13$ & nov/13 & $a b r / 14$ & $a b r / 13$ & nov/13 & $a b r / 14$ & & \\
\hline Tetracloroeteno & $\mu g / L$ & 11 & 5,4 & 15 & 2,1 & $<3,00$ & 3,2 & 5,6 & 1,8 & 4,8 & 40 & 40 \\
\hline Tricloroeteno & $\mu g / L$ & 2.020 & 1.170 & 2.250 & 28 & 20 & 42 & 46 & 27 & 58 & 20 & 20 \\
\hline 1,2-Dicloroeteno (cis+trans) & $\mu \mathrm{g} / \mathrm{L}$ & 42 & 32 & 23 & 7 & 7,7 & 8,7 & $<1,00$ & $<1,00$ & $<1,00$ & $50^{(1)}$ & $50^{(1)}$ \\
\hline 1,1-Dicloroeteno & $\mu \mathrm{g} / \mathrm{L}$ & 6,8 & 11 & 12 & 7,6 & 8,7 & 14 & 4,3 & 1,8 & $<1,00$ & 30 & 30 \\
\hline Cloreto de Vinila & $\mu g / L$ & $<1,00$ & $<1,00$ & $<1,00$ & $<1,00$ & $<1,00$ & $<1,00$ & $<1,00$ & $<1,00$ & $<1,00$ & 2 & 2 \\
\hline 1,1,1-Tricloroetano & $\mu \mathrm{g} / \mathrm{L}$ & $<1,00$ & $<1,00$ & $<1,00$ & $<1,00$ & $<1,00$ & $<1,00$ & $<1,00$ & $<1,00$ & $<1,00$ & - & 2000 \\
\hline 1,1-Dicloroetano & $\mu \mathrm{g} / \mathrm{L}$ & 11 & 5 & 3,7 & 9,6 & 10 & 8,1 & $<1,00$ & $<1,00$ & 6,6 & - & 53 \\
\hline 1,2-Dicloroetano & $\mu g / \mathrm{L}$ & 100 & 60 & 40 & $<1,00$ & $<1,00$ & $<1,00$ & $<1,00$ & $<1,00$ & $<1,00$ & 10 & 10 \\
\hline SOMATÓRIA VOC & & $2.190,8$ & $1.283,4$ & $2.343,7$ & 54,3 & 46,4 & 76,0 & 55,9 & 30,6 & 69,4 & & \\
\hline
\end{tabular}

\begin{tabular}{|c|c|c|c|c|c|c|c|c|c|c|c|c|}
\hline \multirow{3}{*}{ Parâmetros } & \multirow{3}{*}{ Unidade } & \multicolumn{9}{|c|}{ ÁREA 2 (cont) } & \multirow{3}{*}{$\begin{array}{l}\text { Portaria } \\
n^{\circ} 2.914\end{array}$} & \multirow{3}{*}{$\begin{array}{c}\text { CETESB } \\
2014 \\
\text { LI }\end{array}$} \\
\hline & & \multicolumn{3}{|c|}{50} & \multicolumn{3}{|c|}{52} & \multicolumn{3}{|c|}{55} & & \\
\hline & & $a b r / 13$ & nov/13 & $a b r / 14$ & $a b r / 13$ & nov/13 & $a b r / 14$ & $a b r / 13$ & nov/13 & $a b r / 14$ & & \\
\hline Tetracloroeteno & $\mu g / L$ & 34 & 76 & 134 & $<1,00$ & $<1,00$ & 1,3 & \multirow{8}{*}{ 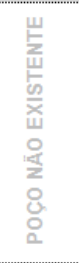 } & $<1,00$ & 1,6 & 40 & 40 \\
\hline Tricloroeteno & $\mu g / L$ & 175 & 219 & 368 & 26 & 15 & 19 & & 9,6 & 15 & 20 & 20 \\
\hline 1,2-Dicloroeteno (cis+trans) & $\mu \mathrm{g} / \mathrm{L}$ & 29 & 48,9 & 41,3 & $<1,00$ & 5,1 & 5,3 & & 2,9 & 3,9 & $50^{(1)}$ & $50^{(1)}$ \\
\hline 1,1-Dicloroeteno & $\mu \mathrm{g} / \mathrm{L}$ & 480 & 556 & 798 & $<1,00$ & 8,7 & 13 & & 5,2 & 11 & 30 & 30 \\
\hline Cloreto de Vinila & $\mu \mathrm{g} / \mathrm{L}$ & $<1,00$ & $<1,00$ & $<1,00$ & $<1,00$ & $<1,00$ & $<1,00$ & & $<1,00$ & $<1,00$ & 2 & 2 \\
\hline 1,1,1-Tricloroetano & $\mu \mathrm{g} / \mathrm{L}$ & $<1,00$ & $<1,00$ & $<1,00$ & $<1,00$ & $<1,00$ & $<1,00$ & & $<1,00$ & $<1,00$ & - & 2000 \\
\hline 1,1-Dicloroetano & $\mu g / L$ & 112 & 150 & 123 & $<1,00$ & 22 & 29 & & 3,5 & 6,8 & - & 53 \\
\hline 1,2-Dicloroetano & $\mu g / L$ & $<1,00$ & $<1,00$ & $<1,00$ & $<1,00$ & $<1,00$ & $<1,00$ & & $<1,00$ & $<1,00$ & 10 & 10 \\
\hline SOMATÓRIA VOC & & 830,0 & $1.049,9$ & $1.464,3$ & 26,0 & 50,8 & 67,6 & - & 21,2 & 38,3 & & \\
\hline
\end{tabular}

LI: Limite de Intervenção

(1) Somatória dos isômeros ou metabólitos

As amostras de solo coletadas na zona não saturada não apresentaram concentrações de compostos orgânicos voláteis acima dos valores orientadores (CETESB, 2014). Segundo Kueper et al. (2003), devido à alta pressão de vapor de alguns compostos DNAPL, a meia vida do contaminante na zona não saturada pode ser bem menor que sua meia vida no meio saturado. O processo de volatilização 
pode degradar solventes clorados residuais como o tricloroeteno e tetracloroeteno, por exemplo, dentro de 5 a 10 anos em climas relativamente quentes e secos.

\section{MATERIAIS E MÉTODOS}

\subsection{SONDAGENS PARA INVESTIGaÇão do AquífERo Fraturado}

Para a investigação do aquífero fraturado na área de estudo, foram realizadas duas sondagens com a posterior instalação de dois poços profundos. A locação destas sondagens é apresentada na figura 20, já citada, e baseou-se na proximidade com as plumas de organoclorados presentes no aquífero freático e nos resultados do mapeamento do topo rochoso na área de estudo, conforme apresentado na tabela 4 .

Tabela 4 - Justificativa da locação das sondagens.

\begin{tabular}{|c|c|}
\hline $\begin{array}{c}\text { Sondagem / } \\
\text { Poço }\end{array}$ & Justificativa de Locação \\
\hline PP-01 & $\begin{array}{r}\text { Próximo à pluma de 1,2-dicloroeteno e lineamento } \\
\text { identificado na fotointerpretação }\end{array}$ \\
\hline PP-02 & $\begin{array}{r}\text { Próximo à pluma de tricloroeteno e ao lineamento } \\
\text { identificado na fotointerpretação }\end{array}$ \\
\hline
\end{tabular}

Para a realização destas sondagens foi utilizada uma sonda rotopneumática modelo R1HS com capacidade para perfurar até 400 metros e de propriedade da empresa Hidrodex Engenharia e Perfuração Ltda. Esta sonda opera com dois sistemas distintos: o sistema rotativo, que funciona à base de circulação de um fluido e o sistema rotopneumático, que funciona à base de ar comprimido.

A perfuração foi realizada em duas etapas. A primeira consistiu na perfuração do solo de alteração e posterior instalação da proteção sanitária, a fim de isolar o aquífero freático e assim evitar a percolação da água contaminada para as regiões mais profundas do aquífero cristalino. A segunda etapa consistiu na perfuração da rocha sã até a profundidade desejada.

O método rotativo com circulação direta, utilizado na primeira etapa para perfurar o manto de alteração, consiste na rotação de uma coroa cortante com aplicação simultânea de pressão para avanço vertical, podendo atingir grandes 
profundidades. O fluido utilizado foi água potável, retirada do próprio reservatório industrial. Este fluido foi injetado para dentro da coluna de perfuração por bombeamento através de um sistema contínuo e fechado, retornando à superfície juntamente com o material perfurado por uma estrutura nomeada 'cachimbo'.

Para auxiliar na suspensão do material perfurado foi empregado também um espessante biodegradável denominado CMC (carboximetilcelulose de sódio). A figura 21 ilustra alguns dos componentes empregados no método rotativo.
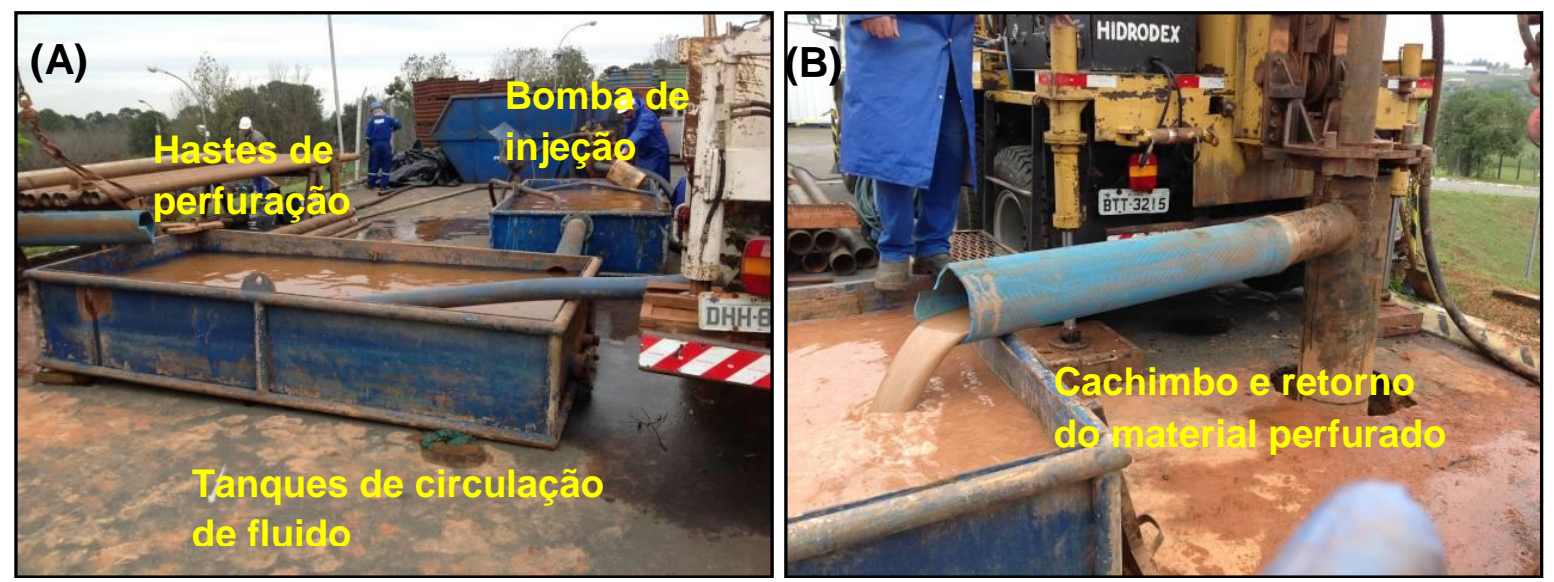

Figura 21 - (A) Tanques de circulação de fluido utilizados no método rotativo; (B) Retorno do material perfurado através do 'cachimbo'

$\mathrm{Na}$ perfuração do PP-01, a etapa rotativa foi realizada com uma broca de diâmetro 12.1/4" até a profundidade de 18,0 m. A partir dos 10,0 metros, observou-se que a água injetada não estava retornando com o material perfurado, dificultando assim o avanço da perfuração. Deste modo, optou-se por realizar o revestimento deste trecho perfurado (até os $18 \mathrm{~m}$ ) com um tubo de aço de 10", a fim de minimizar as perdas de água para a formação geológica. Após o revestimento, a perfuração prosseguiu com uma broca de $9.7 / 8$ " (figura 22) até a profundidade de $45 \mathrm{~m}$, sendo o topo rochoso identificado na profundidade de $39,5 \mathrm{~m}$.

A perfuração do PP-02 foi realizada com a utilização de broca de diâmetro $12.1 / 4$ " até a profundidade de $34 \mathrm{~m}$, sendo o topo da rocha identificado em 30,0 m. Durante a perfuração deste ponto, também foi observada perda de água em aproximadamente 5,5 metros de profundidade, sendo necessária adição do espessante CMC para dar mais viscosidade ao fluido e auxiliar na retirada do material perfurado de dentro do furo. 

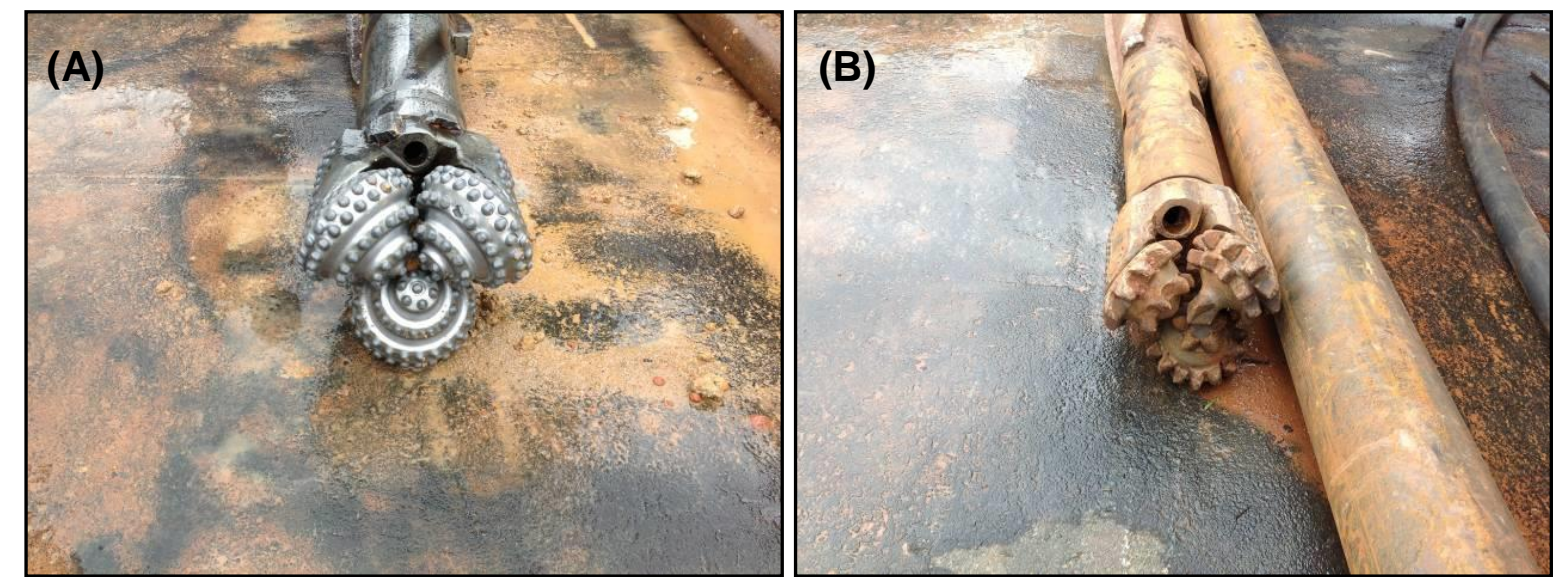

Figura 22 - Brocas utilizadas na etapa de perfuração rotativa. (A) Broca de diâmetro 12.1/4"; (B) Broca de diâmetro 9.7/8"

A perda de água neste ponto ocorreu devido à presença de um formigueiro, que pode formar caminhos preferenciais no solo de alteração. A água injetada provavelmente inundou o formigueiro, ocasionando a fuga das formigas, que foram observadas na superfície de um talude localizado próximo ao ponto perfurado.

Após a perfuração do manto de alteração com o método rotativo, avançou-se na porção rochosa ainda alterada por aproximadamente 5,0 metros sendo realizado o revestimento de toda seção perfurada com tubos de aço carbono de 6", soldados entre si. $\mathrm{O}$ avanço de alguns metros na rocha permitiu assegurar que todo o aquífero freático foi selado.

Após o posicionamento dos tubos de aço, prosseguiu-se com a selagem das paredes do furo com a injeção de calda de cimento entre a parede do revestimento e a parede do furo. $O$ revestimento e a selagem da seção perfurada tiveram o intuito de sustentar as paredes do furo, além de isolar o aquífero freático, evitando desta forma a mistura com a água do aquífero cristalino e possíveis eventos de contaminação cruzada.

A cimentação no PP-02 foi realizada de baixo para cima onde o cimento é injetado por pressão por dentro das hastes saindo pela lateral de uma válvula de cimentação, preenchendo toda a parede entre o furo e o tubo de revestimento. Durante a cimentação do PP-01, verificou-se o entupimento desta válvula, sendo necessário realizar a cimentação de cima para baixo, com a ajuda de uma mangueira. Toda a parte externa e interna do revestimento foi cimentada até o transbordo do material, garantindo o completo selo do furo. 
Após a secagem do cimento, foi realizada a perfuração na rocha sã, com a utilização do método rotopneumático. Este método é baseado numa percussão em alta frequência e de pequeno curso dado por um martelo em uma broca de tungstênio de 6" (figura 23), que concomitantemente é rotacionada triturando e desgastando a rocha. O fluido empregado é o próprio ar comprimido transmitido por um compressor de grande porte para dentro da coluna de perfuração, passando pelo martelo e broca. $O$ ar comprimido auxilia também na retirada do material de dentro do furo.
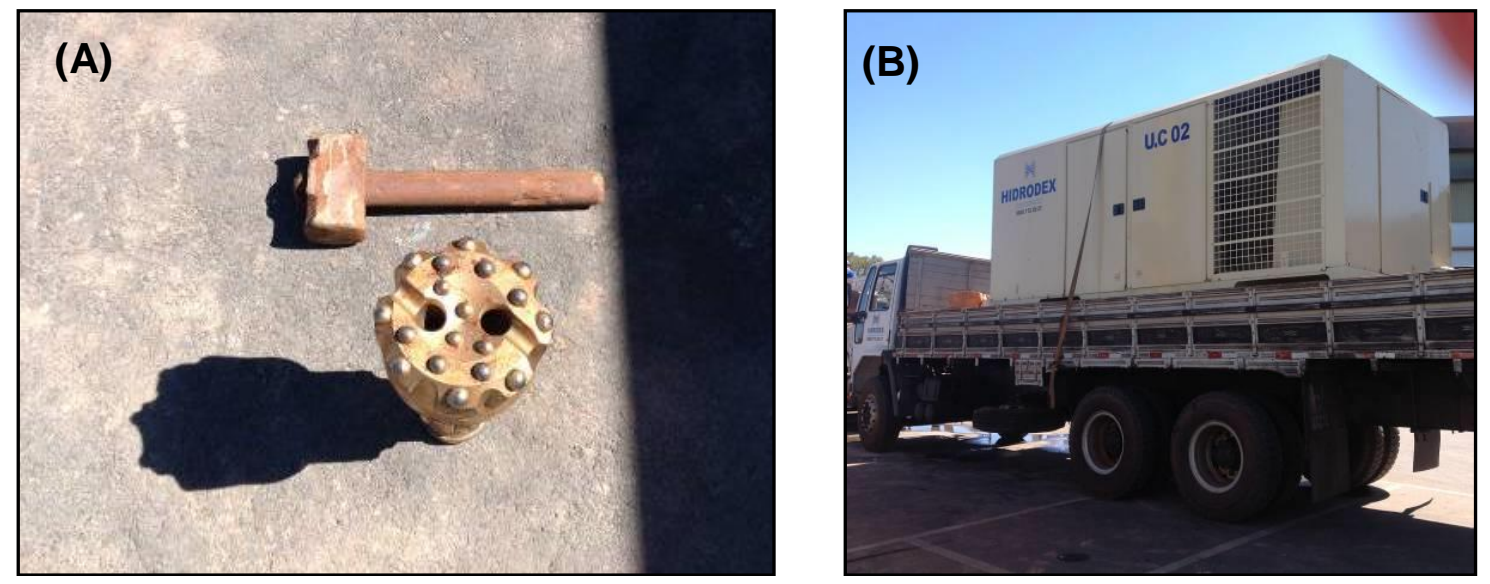

Figura 23 - (A) Broca de Ø6" de tungstênio utilizada no método rotopneumático; (B) Unidade compressora que alimenta o sistema de martelo e broca no método rotopneumático

Durante a perfuração foram realizadas anotações da resistência da máquina à perfuração, indicações de fluxo de água e descrições do perfil litológico através de amostras de calha. As profundidades máximas atingidas na rocha neste trabalho foram 78,0 m no ponto PP-01 e 92,0 m no ponto PP-02.

Todo o material gerado durante a etapa de perfuração foi acondicionado em tanques para posterior descarte. A parte líquida foi bombeada para dentro do caminhão tanque e posteriormente descartada na Estação de Tratamento de Efluentes da própria unidade industrial.

Após o término das perfurações foi realizada a limpeza do poço com a injeção de ar pelo compressor, de modo a garantir a remoção de qualquer fluido de perfuração utilizado. 


\subsection{Perfilagens Geofísicas}

A fim de extrair informações mais detalhadas do perfil litológico dos pontos perfurados e caracterizar as principais descontinuidades presentes no maciço rochoso foram realizadas diferentes técnicas de perfilagens geofísicas.

Neste trabalho foram executadas as perfilagens de raios gama, cáliper e acústica (HRAT - High Resolution Acoustic Televiewer), além da filmagem do furo, sendo a empresa Hydrolog Serviços de Perfilagem Ltda. responsável pela aquisição dos dados geofísicos. A perfilagem com Flowmeter foi realizada pela empresa Pangea Geologia e Estudos Ambientais.

Os dados obtidos pelas perfilagens foram importados para o software WellCAD v. 5 e analisados em conjunto. Através do programa foi possível a identificação de foliações e feições de fraturas bem como sua atitude (direção e mergulho).

O trabalho de coleta de dados através das perfilagens ocorreram durante o segundo semestre de 2013 e cada uma das técnicas é descrita a seguir.

\subsubsection{Filmagem da perfuração}

A filmagem do furo foi executada antes das perfilagens geofísicas, uma vez que a qualidade das imagens obtidas depende da transparência da água dentro da perfuração e qualquer movimentação pode ocasionar o aumento da turbidez e consequentemente a perda da qualidade da filmagem.

O principal objetivo desta etapa foi a caracterização da rocha que compõe o aquífero fraturado, uma vez que as imagens auxiliaram na identificação com maior precisão das variações composicionais e faciológicas típicas do gnaisse local. Adicionalmente, a filmagem colaborou para a identificação das zonas de fraturas e intervalos mais intemperizados.

A ferramenta de filmagem utilizada é composta de duas câmeras independentes que permitem filmar verticalmente, visando o fundo do poço, ou lateralmente, visando as paredes do poço. Ambas as câmeras podem ser operadas em modo estacionário ou giratório durante a mesma descida (figura 24). As imagens foram capturadas durante a descida das câmeras, sendo a subida utilizada para esclarecer dúvidas e rever as principais feições. 

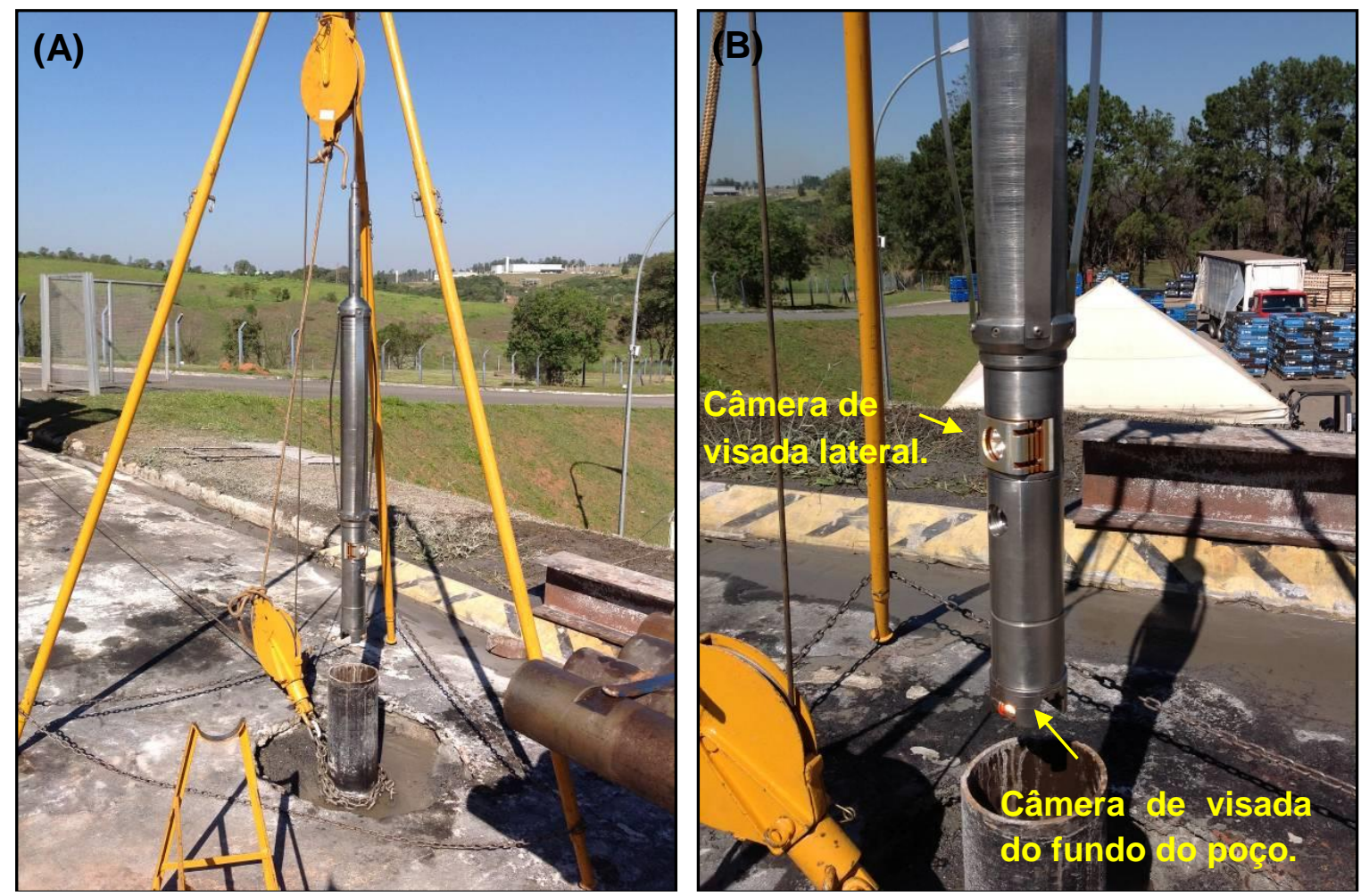

Figura 24 - (A) Tripé e demais equipamentos utilizados na descida da câmera para dentro da seção perfurada durante a perfilagem ótica; (B) Detalhe das câmeras presentes na sonda

\subsubsection{Perfilagem de Calibre}

O compasso calibrador (cáliper), localizado na extremidade da sonda, é constituído por três hastes articuladas (ou braços), conforme apresentado na figura 25, proporcionando maior precisão nos registros obtidos. As variações de diâmetro registradas durante a subida do equipamento podem fornecer informações sobre a litologia e possíveis aberturas (fraturas) ou zonas de fraquezas da rocha.

A perfilagem de raios gama é geralmente utilizada em conjunto com a perfilagem cáliper, auxiliando na interpretação dos dados, uma vez que em zonas de fraturas, as cavidades da rocha são identificadas pela diferença na abertura das hastes do cáliper e a radiação gama nesses locais tende a ser menor do que em porções onde a rocha encontra-se íntegra, sem descontinuidades. 


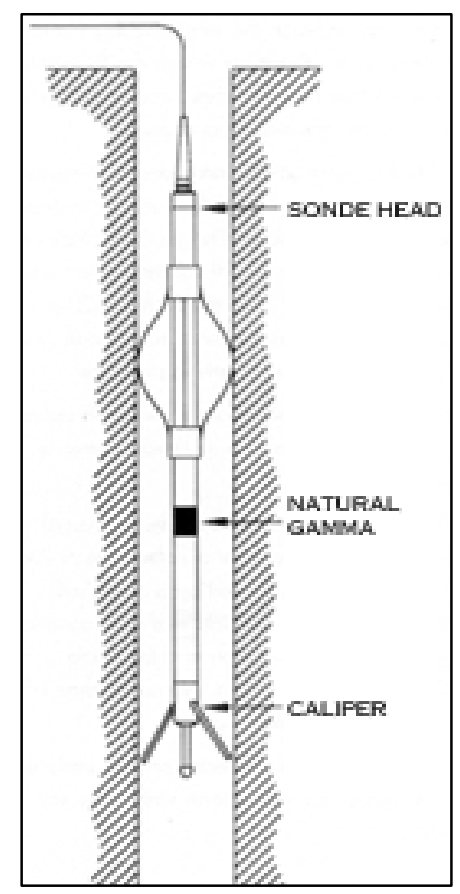

Figura 25 - (A) Esquema da sonda utilizada na perfilagem cáliper (FONTE: Hydrolog. http://www.hydrolog.com.br/portugues/conteu do/index/cáliper-slim);

\subsubsection{Perfilagem HRAT (High Resolution Acoustic Televiewer) e Raios Gama}

No presente trabalho, foi utilizada uma única sonda que realiza simultaneamente a perfilagem HRAT e a detecção dos raios gama (figura 26). $\mathrm{O}$ objetivo do uso desta perfilagem no atual trabalho foi identificar as diferentes famílias de fraturas interceptadas pelas perfurações realizadas, estudando suas direções e mergulhos (chamadas de atitudes) e tentando correlacioná-las com as descontinuidades mapeadas em superfície durante o estudo. Cabe ressaltar que o conhecimento das atitudes das fraturas poderá auxiliar na compreensão da conectividade destas estruturas e na capacidade de condução de água e também de possíveis contaminantes em profundidade.

A perfilagem HRAT foi realizada nos pontos PP-01, PP-02 perfurados e também em um trecho do poço tubular P5 que se encontra desativado, a fim de auxiliar no entendimento das principais zonas de fraturas.

A radiação gama é captada por um cintilômetro conforme a sonda avança em profundidade e o resultado em contagem por segundo (cps) é apresentado na forma de gráficos. Há correções que transformam as medições de cps para escalas quantitativas, como porcentagem, por exemplo. Os picos representados no gráfico mostram zonas ricas nos elementos $\mathrm{K} / \mathrm{U} / \mathrm{Th}$. As zonas de menor radiação podem estar relacionadas com possíveis fraturas ou com diferenças na litologia, por exemplo. 
Para o imageamento acústico de alta resolução, foi utilizada uma sonda da marca Robertson Geologging Ltda de 1.3/4" de diâmetro e 1,98 m de comprimento, com resolução vertical de até $1 \mathrm{~mm}$.
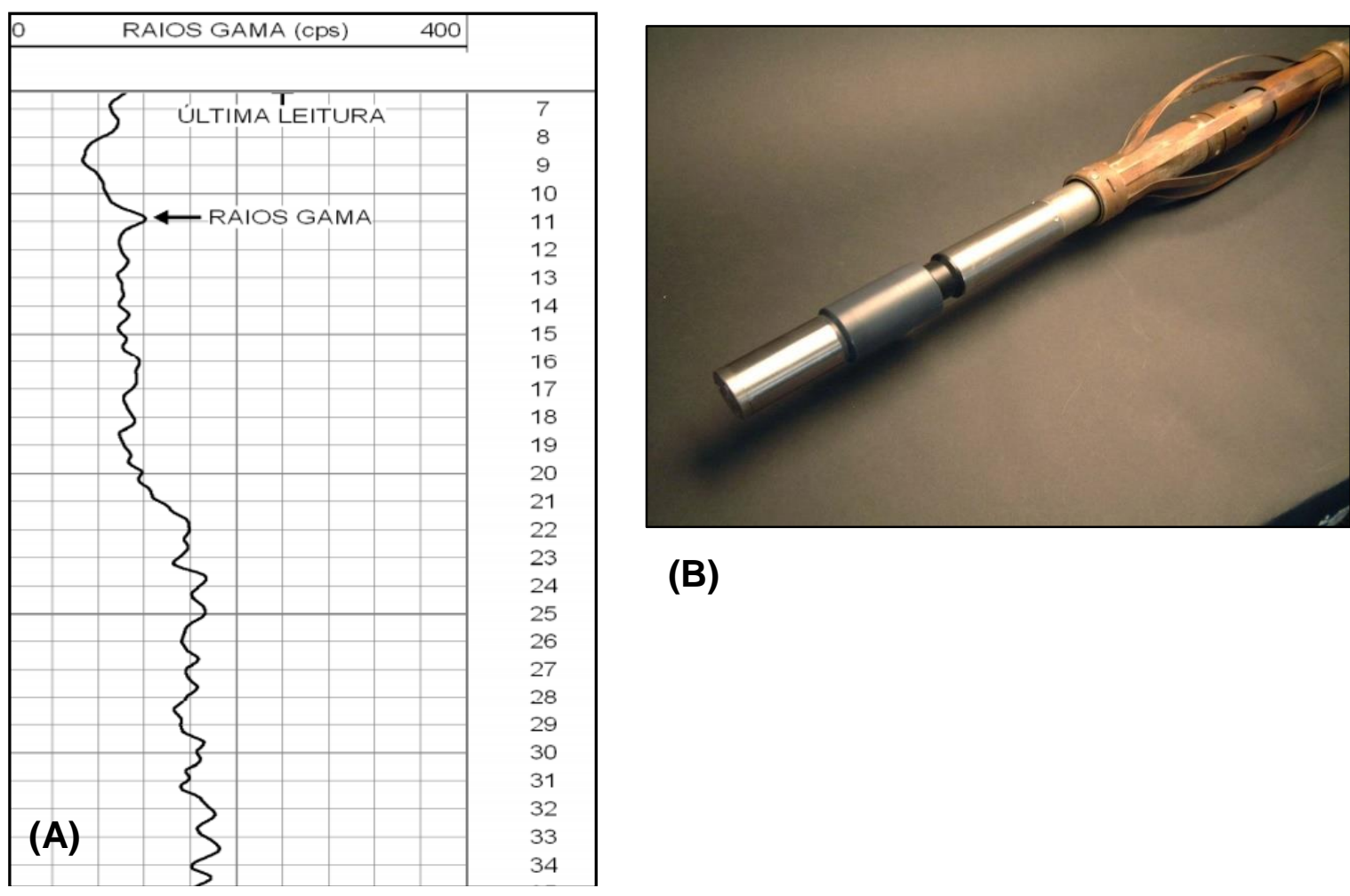

(B)

Figura 26 - (A) Exemplo de gráfico gerado na captação da radiação gama. (B) Sonda acústica utilizada.

\subsubsection{Tratamentos dos dados estruturais}

Os dados obtidos pela perfilagem acústica foram importados para o programa WellCad v.5 e as feições de fraturas foram traçadas e classificadas de acordo com seu grau de incerteza.

Traçados definidos, feições mais espessas, ou que foram identificadas em mais de uma perfilagem, foram desenhadas em azul e representam as feições características de Fraturas. Já as feições traçadas em rosa indicam as Possíveis Fraturas e são compostas por traçados mais sutis ou descontínuos e que não foram observados nas demais perfilagens. Foram também tomadas algumas medidas de Foliação da rocha em cada um dos pontos analisados, sendo essa feição representada em verde nas perfilagens (Anexo 1). 
Os dados estruturais (atitude das fraturas) obtidos através da análise dos dados estão apresentados na notação da bússola Clar (rumo do mergulho e ao ângulo de mergulho) e foram primeiramente compilados em planilhas do Excel (Anexo 2) e posteriormente plotados e analisados em estereogramas, diagramas de densidade e histogramas para definição dos diferentes grupos de fraturas presentes.

Para esse tratamento dos dados, foi utilizado o software DIPS v.5.1, com projeção de igual área (rede Schmitd-Lambert) no hemisfério inferior que permite a representação de elementos planares e lineares situados no espaço com preservação das relações angulares.

Os principais grupos ou famílias de fraturas do maciço foram caracterizados para auxiliar no entendimento das principais zonas de fluxo de água e possivelmente de contaminantes.

Para análise da densidade e espaçamento das fraturas, foi utilizado o método elaborado por Terzaghi (1965) e adaptado por Pino (2012) que utiliza os estereogramas para ajustar a densidade de fraturas (com $\alpha>20^{\circ}$ ) interceptadas pela sondagem.

Essa correção é necessária uma vez que os dados das fraturas obtidos pelas perfilagens são afetados pelo viés de orientação da perfuração e pelo espaçamento aparente das fraturas, que está relacionado com o ângulo $(\alpha)$ que a fratura faz com o eixo de perfuração.

Neste trabalho as sondagens perfuradas na rocha foram verticais, orientadas $90^{\circ}$ em relação à superfície do solo. Deste modo, fraturas com baixo ângulo de mergulho ou ortogonais ao eixo do furo são facilmente interceptadas, enquanto as fraturas com altos ângulos de mergulho são mais difíceis de serem amostradas. Fraturas paralelas ao eixo não são interceptadas. Consequentemente a densidade e o espaçamento das fraturas de cada um dos grupos identificados podem não ser adequadamente representados.

A figura 27 ilustra o espaçamento aparente (d') e espaçamento verdadeiro (d) das fraturas interceptadas pelo furo de sondagem e sua relação com o ângulo ( $\alpha$ ), formado pelo furo de sondagem orientado e as fraturas interceptadas. Quanto menor o ângulo $\alpha$, menor a chance de as fraturas serem interceptadas.

No caso da perfuração vertical, o ângulo ( $\alpha$ ) é obtido pela subtração do ângulo de mergulho da fratura pelo ângulo de mergulho do furo. 
O método desenvolvido por Terzaghi envolve a aplicação de um fator de correção a cada feição observada, a fim de aumentar a acuracidade dos dados. O peso atribuído pelo fator de correção representa a quantidade de fraturas de mesma orientação e mergulho que deveriam ser observadas ao longo da perfuração, caso fossem interceptadas com um ângulo de $90^{\circ}$ em relação a perfuração.

Assim, o número de fraturas $(\mathrm{N \alpha})$ interceptadas por um determinado ângulo $(\alpha)$ é substituído por um valor N90 que é representado pelo número de fraturas de mesma orientação, observadas perpendiculares ao eixo.

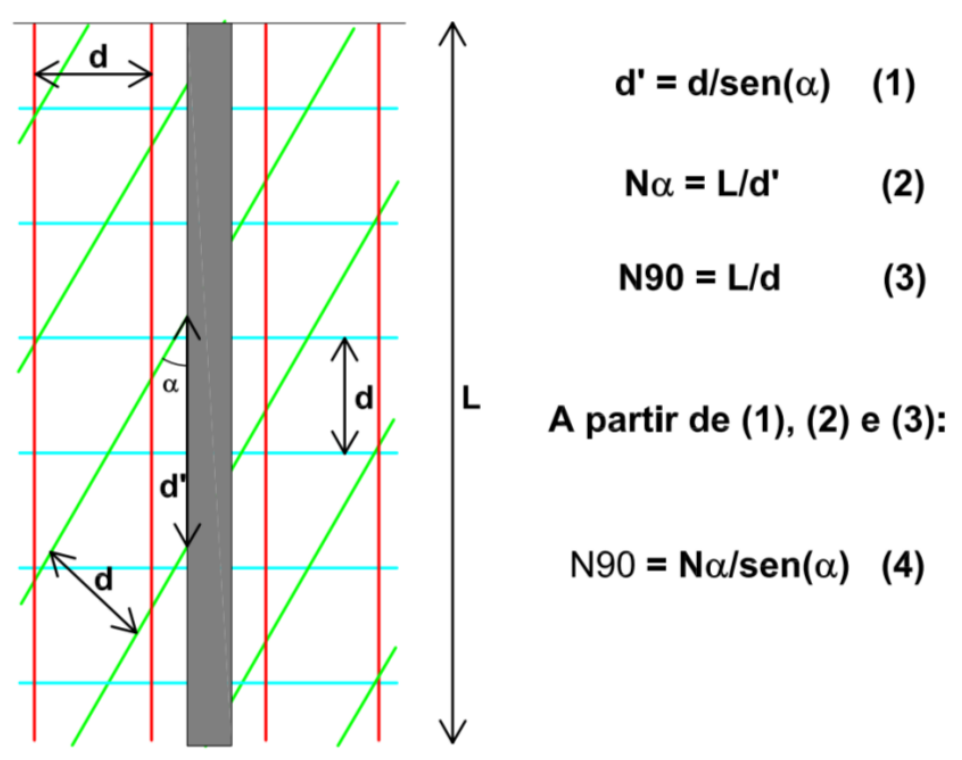

Figura 27 - Figura esquemática de uma seção vertical de um furo mostrando três orientações diferentes de fraturas, todas com o mesmo espaçamento ortogonal (d). A fraturas em azuis são corretamente amostradas $(n=6)$, as fraturas em verde são subamostradas e as fraturas em vermelho não são interceptadas pela perfuração (Modificado de Task Geoscience, 2008)

Terzaghi ressalta, no entanto, que não é possível realizar correções adequadas para valores baixos de a, uma vez que o número de interseções na rocha é significativamente afetado pela variação local de espaçamento e continuidade das juntas se $\alpha$ for pequeno. Nenhuma correção pode também ser aplicada se o ângulo a for igual à zero. Deste modo, para diminuir a incerteza, é recomendável a observação de pelo menos três furos com mergulhos de $45^{\circ}$ e diferença de $120^{\circ}$ entre a orientação de cada um dos traços. Assim, fraturas em qualquer orientação devem ser interceptadas por pelo menos um dos furos com um ângulo maior ou igual a $31^{\circ}$ (Terzaghi, 1965). 
Neste trabalho, foram elaborados estereogramas aplicando a correção de Terzagui nas fraturas com ângulo $\alpha$ maior que $20^{\circ}$ e estereogramas sem a correção de Terzagui para avaliação das fraturas com ângulos a menores que $20^{\circ}$, com ressalva de que podem estar subestimadas.

Segundo Pino (2012), esse método de correção do viés de orientação é particularmente interessante uma vez que produz uma estimativa da verdadeira densidade de fraturas, em oposição à sua frequência de observação.

Para análise do espaçamento, foram considerados os valores de N90 corrigidos para as fraturas com ângulo $\alpha$ maior que $20^{\circ}$ e os valores absolutos para as demais fraturas que não foram corrigidas, garantindo assim que todas as feições observadas serão consideradas.

Dividindo o total de fraturas observadas após a correção, pelo comprimento do eixo perfilado ou pela seção de sua abrangência, é possível obter uma estimativa da verdadeira densidade e do espaçamento das fraturas.

Observando o padrão de distribuição das fraturas ao longo do perfil, foi possível distinguir 3 zonas diferentes, sendo:

1) Zona superior da rocha, mais alterada, mesossomática

2) Zona de transição

3) Zona mais profunda, menos alterada, leucocrática.

Assim, a distribuição das fraturas em cada ponto investigado foi realizada levando em consideração as zonas acimas citadas. Cada grupo de fratura foi analisado individualmente, sendo classificados conforme modelo utilizado por Pino (2012) em distribuição (a) aleatória, (b) regular, (c) regular variada, ou (d) regular concentrada, conforme exemplificado na figura 28. 
(A)

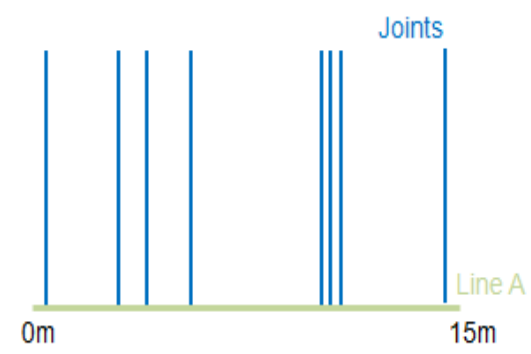

(C)

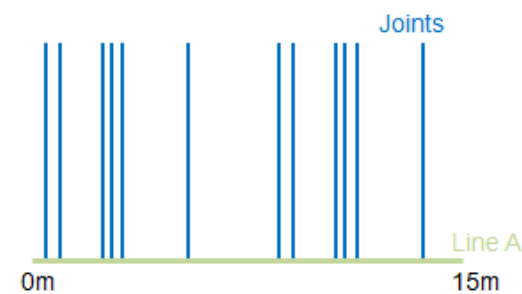

(B)

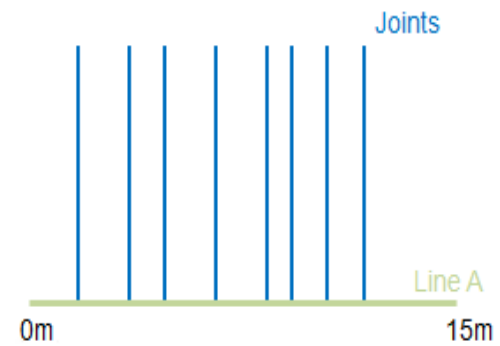

(D)

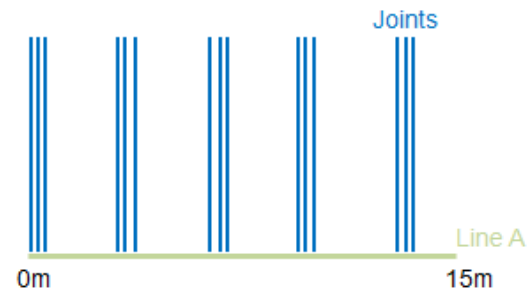

Figura 28 - Exemplos de diferentes tipos de distribuição das fraturas que podem ser (A) aleatórias, (B) regular, (C) regular variada, ou (D) regular concentrada (PINO, 2012)

\subsubsection{Perfilagem Flowmeter}

A perfilagem realizada pelo Flowmeter tem como objetivos a obtenção do sentido de fluxo de água subterrânea ao longo do furo, a determinação da velocidade de fluxo em locais pontuais e a determinação das principais entradas de água subterrânea através de fraturas ou zonas de fraturas previamente identificadas pelas perfilagens anteriores.

O Flowmeter utilizado foi do tipo pulso de calor e é da marca Robertson Geologging (figura 29). O equipamento permite uma leitura com resolução de 0,001 $\mathrm{m} / \mathrm{min}$ em até 30 segundos decorridos da emissão do pulso de calor, sendo que, passado esse tempo, o fluxo é tido como nulo. O gráfico apresentado pelo software de aquisição de dados WinLogger pode ser visualizado na Figura 30.

A velocidade é calculada pelo software utilizando a Equação 4, que converte o tempo de leitura do pulso em velocidade do fluxo:

$$
V=[-1,5156 \ln (t)]+5,2502
$$




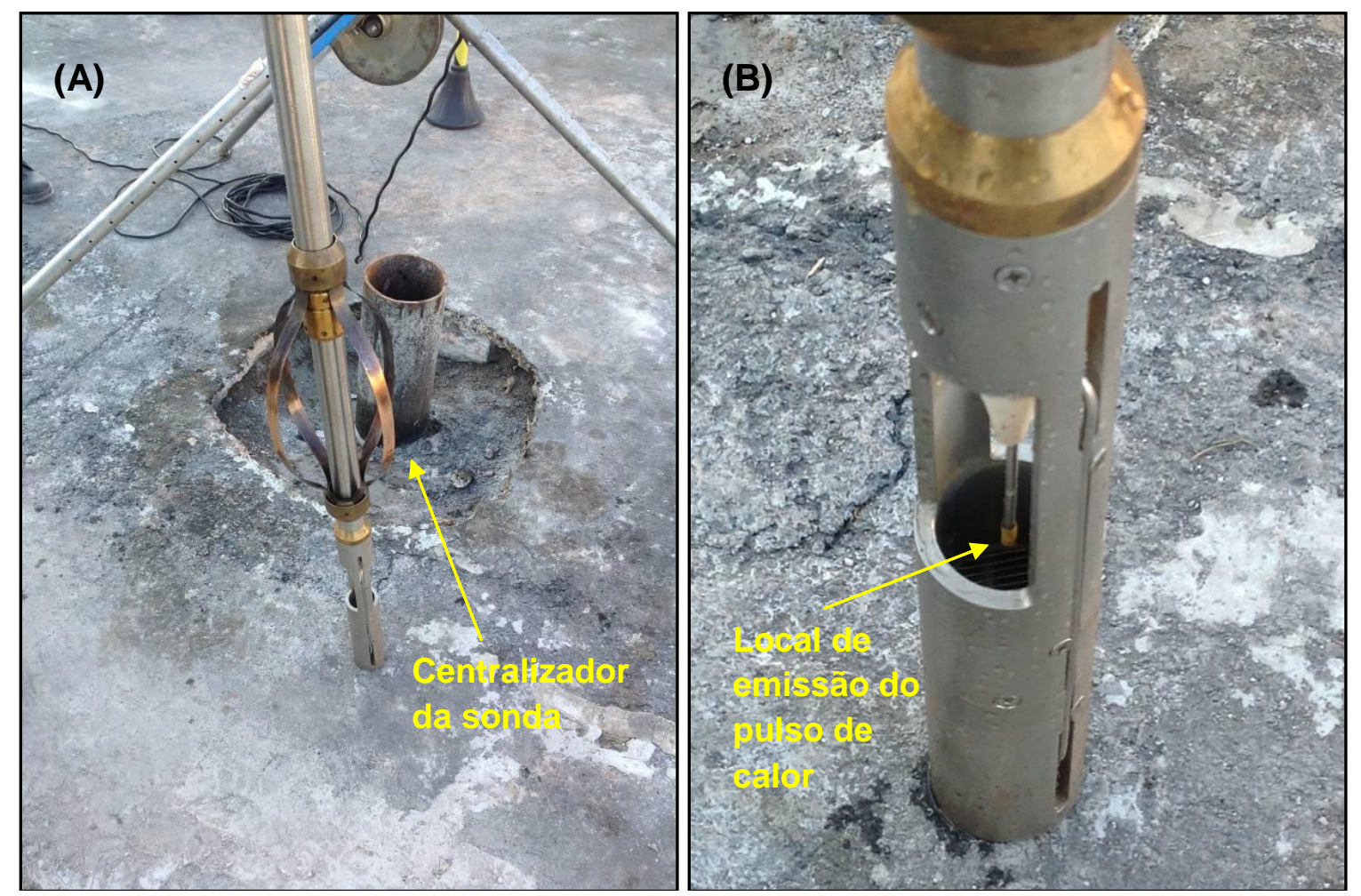

Figura 29 - (A) Sonda utilizada na perfilagem flowmeter; (B) Detalhe da ponteira da sonda, onde ocorre a emissão do pulso de calor

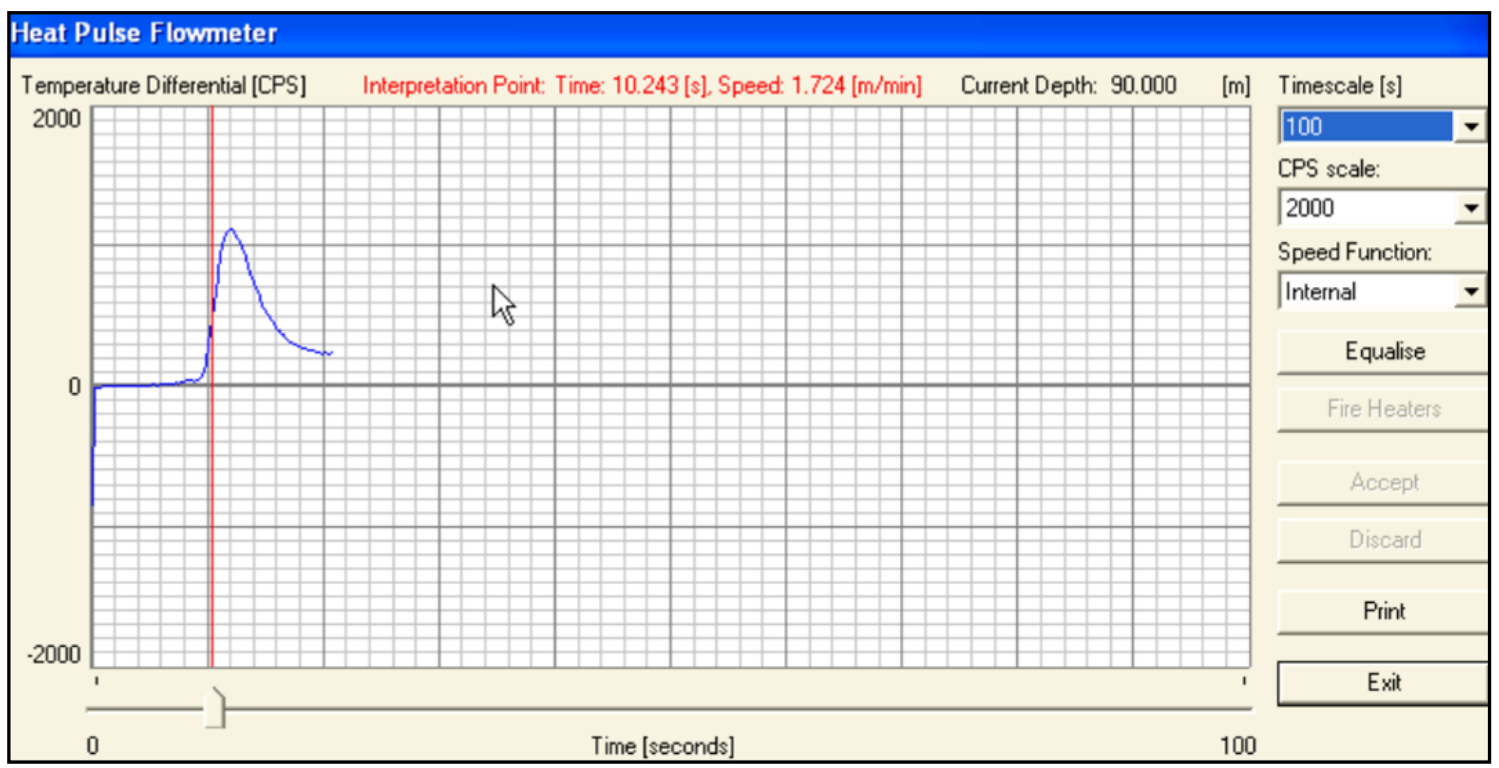

Figura 30 - Gráfico de inflexão positiva apresentado pelo software de aquisição de dados obtidos com o flowmeter. O ajuste da linha vermelha indica o ponto escolhido em que o tempo decorrido será convertido em velocidade de fluxo

A fim de detectar possíveis entradas e saídas de água no furo, são realizadas medições antes e depois de fraturas e zonas de fraturas previamente identificadas através do resultado das perfilagens anteriores. São realizadas pelo menos 3 medições em cada ponto, sendo geralmente descartada a primeira medição ou 
alguma outra medição que estiver discrepante da média das demais. As fraturas de interesse são aquelas que apresentaram evidências de abertura, possuindo maior probabilidade de fluxo.

\subsection{Amostragem do Aquífero Cristalino com o Emprego de Obturadores Pneumáticos}

Antes da instalação definitiva dos poços de monitoramento nos locais perfurados, foi realizada a coleta de amostras de água diretamente das fraturas do aquífero cristalino com o uso de obturadores pneumáticos, equipamento que permite o isolamento de trechos da seção perfurada, possibilitando assim a coleta de água em um intervalo determinado.

Os trabalhos seguiram as recomendações presentes no Guia Nacional de Coleta de Amostras (CETESB \& ANA, 2011) e considerados os procedimentos estabelecidos na ASTM D-6771-02 (ASTM, 2002).

Os obturadores pneumáticos foram construídos pela empresa Hidrodex Engenharia e Perfuração, com o auxílio da Waterloo Brasil e foram baseados nos modelos previamente desenvolvidos pelo Serviço Geológico Americano (USGS) e adaptado de acordo com a tecnologia e os equipamentos disponíveis no Brasil.

Os obturados consistem em dois cilindros de borracha de $15 \mathrm{~cm}$ de espessura separados por uma haste central de aço de $1.1 / 2$ " com 3,70 m de comprimento, por onde se posiciona a bomba de amostragem. Devido à necessidade de se detectar a presença de compostos orgânicos voláteis mesmo em baixas concentrações, foi utilizada uma bomba de baixa vazão (low flow) para realização da amostragem. Optou-se por não fixar a bomba entre os obturadores, sendo a mesma inserida pela superfície dentro da haste principal de sustentação, que é oca e possui abertura somente na porção filtrante entre os obturadores, possibilitando a entrada de água do trecho obturado para o interior da bomba. Deste modo, foi possível realizar a limpeza da bomba e troca das mangueiras entre um ponto e outro, evitando a contaminação cruzada pelo equipamento de amostragem.

Os cilindros de borracha do obturador são interconectados por uma mangueira de $1 / 2$ " e são inflados concomitantemente através da inserção de ar sob pressão. Para inflar os obturadores e selar o furo de 6", foram utilizadas pressões de 50 psi a 60 psi, controlada em superfície através de um manômetro. 
Além da mangueira de injeção de ar e da haste de passagem de água, o sistema de obturadores utilizados conta também com dois tubos de PVC de 1" por onde é feito o controle da profundidade do nível d'água (N.A.), tanto entre os obturadores, quanto na porção superior fora deles, conforme pode ser observado na figura 31.

O controle do nível de água (N.A.) fora e dentro do obturador é imprescindível, pois traz informações sobre a mudança no nível de água durante o bombeamento, permitindo verificar se os cilindros realmente selaram o trecho previamente escolhido para amostragem. Todo o conjunto descrito é levado para dentro do furo com a ajuda de um guincho e de hastes de aço acopláveis que variam de $6 \mathrm{~m}$ a $1 \mathrm{~m}$ cada.
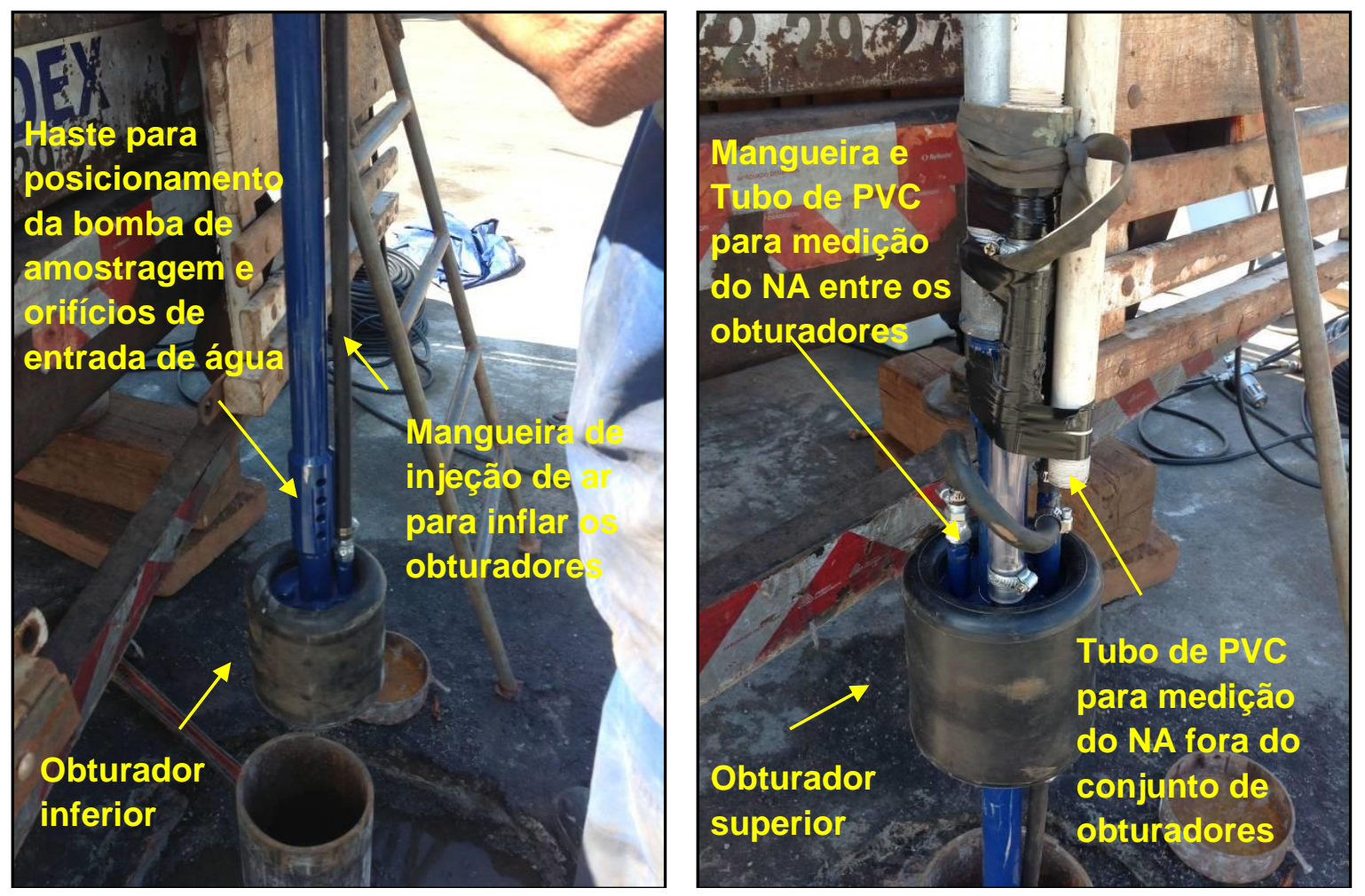

Figura 31 - Sistema de obturadores utilizados

Para a definição dos intervalos a serem amostrados, foi feita uma compilação dos resultados obtidos nas perfilagens geofísicas, levando em consideração a posição das principais fraturas em profundidade e as diferenças de velocidade de fluxo medido pelo Flowmeter nos intervalos determinados. No total, foram selecionados três intervalos distintos de amostragem em cada um dos furos para análises de $\mathrm{VOC}$, partindo do nível mais profundo (amostra $\mathrm{C}$ ) para o mais raso (amostra A). 
Os trabalhos de bombeamento da água do aquífero cristalino e coleta de amostras deste sistema foram realizados através da técnica de baixa vazão (low flow). Nesta técnica a velocidade deve ser ajustada para que cause o mínimo de turbulência no aquífero, assegurando desta forma a transparência da água e a não volatilização de compostos orgânicos voláteis, garantindo amostras representativas do aquífero em estudo.

Antes da coleta das amostras de água, foram medidos os níveis de água estáticos nas duas seções (dentro e fora do obturador). Os obturadores foram posicionados na maior profundidade entre os três trechos previamente escolhidos e a bomba modelo Double Valve 408 posicionada na extremidade final da haste que separa os obturadores. Os cilindros de borracha foram então inflados, aguardando um tempo mínimo de 30 minutos ou até a estabilização dos níveis de água interno e externo para início da purga.

Durante a purga foi realizado o monitoramento da variação do nível d'água tanto no trecho isolado pelos obturadores como também fora deste sistema, a fim de verificar se o isolamento pelos cilindros de borracha estava sendo eficiente. Além do monitoramento do nível d'água, os parâmetros $\mathrm{pH}$, condutividade elétrica, potencial de oxi-redução (Eh), temperatura e oxigênio dissolvido (OD) foram constantemente monitorados até sua estabilização, para posterior coleta das amostras em frascos apropriados.

De acordo com a ASTM (2002), são consideradas estáveis variações máximas nas últimas 3 leituras para mais ou para menos de $0,5{ }^{\circ} \mathrm{C}$ de temperatura; 0,2 unidades de $\mathrm{pH} ; 20 \mathrm{mV}$ de Potencial Redox (Eh); 0,2 ou 10\% de Oxigênio Dissolvido (OD) e $5 \%$ de variação na Condutividade Elétrica.

A utilização da bomba de baixa vazão modelo Double Valve 408 de pequeno diâmetro possibilitou a passagem da mesma por dentro dos tubos de sustentação dos equipamentos, mesmo com as hastes em profundidade e com os obturadores inflados, facilitando a limpeza da bomba entre os pontos amostrados. No entanto, não foi possível realizar ensaios hidráulicos nos intervalos isolados tendo em vista sua baixa vazão.

As amostras de água subterrânea coletadas nas três profundidades foram preservadas e enviadas para o laboratório BioAgri Ambiental para análise de compostos orgânicos voláteis (VOCs). 


\subsection{Instalação dos Poços de Monitoramento no Aquífero Cristalino}

Após o recebimento dos resultados das análises químicas, os trabalhos prosseguiram com a instalação de poços de monitoramento nos locais perfurados, sendo os filtros posicionados nos intervalos em cuja amostra foram detectadas as maiores concentrações de compostos orgânicos e que possuem grande variação de fluxo de água.

A fim de evitar que os furos realizados se tornassem uma nova via de percolação para a contaminação, foi feita a cimentação do restante da seção perfurada. A injeção da calda de cimento foi realizada sob gravidade, com a utilização de tubulações para condução do cimento até o fundo do furo, sendo a instalação dos poços realizada após a secagem do cimento. A instalação foi feita utilizando-se revestimentos geomecânico de PVC de 2" rosqueáveis entre si, e filtros com ranhuras de $0,25 \mathrm{~mm}$ de abertura. $\mathrm{Na}$ base da tubulação foi colocada uma tampa (cap) para fechamento.

No espaço anelar entre o tubo e a parede do furo foi inserido o pré-filtro, composto de areia fina (granulometria 0,06 a $0,15 \mathrm{~mm}$ ), colocada até a profundidade de aproximadamente 3,5 metros acima da seção filtrante. Para estes poços foi utilizado mais material de pré-filtro que o convencional a fim de evitar que a calda de cimento, injetada sob pressão e utilizada para a confecção do selo sobre o pré-filtro, percolasse e obstruísse a entrada de água pelos filtros.

$\mathrm{Na}$ extremidade superior do poço foi colocado um grip de pressão para fechamento hermético do mesmo. Posteriormente, foi confeccionado o selo sanitário (caixa de concreto) ao redor da boca do poço onde foi afixada uma câmara de calçada metálica com tampa de 8" para proteção da boca do furo e tubo.

\subsection{Ensaios de Permeabilidade}

O ensaio de permeabilidade foi realizado nos poços de monitoramento já instalados, visando calcular a condutividade hidráulica $(K)$ dos diferentes grupos de fraturas interceptados pela seção filtrante do poço.

Foram realizados ensaios de permeabilidade baseados na recuperação do nível de água do poço após um determinado período de bombeamento, aproveitando-se da atividade de desenvolvimento do poço. Medidas de níveis de água foram anotadas em intervalos de tempo regulares, até a recuperação do nível 
de água ou pelo período de 30 minutos, obtendo-se desta forma uma curva característica de recuperação versus tempo.

Os dados foram tratados no programa Aquifer Test ${ }^{\circledR}$ utilizando o método de cálculo desenvolvido por Hvorslev (1951) para determinação da condutividade hidráulica do poço. Neste método a condutividade hidráulica é calculada através da seguinte fórmula:

$$
K=\frac{r^{2} \cdot \ln (L / R)}{2 L \cdot T_{L}}
$$

Onde:

$$
\begin{aligned}
& \mathrm{K}=\text { condutividade hidráulica } \\
& \mathrm{r}=\text { raio do tubo } \\
& \mathrm{L}=\text { comprimento da seção filtrante do poço } \\
& \mathrm{R}=\text { raio do furo } \\
& \mathrm{T} L=\text { tempo correspondente a } \mathrm{H}-\mathrm{h} / \mathrm{H}-\mathrm{ho}=0,37 \text { (sendo } \mathrm{h}_{0}=\text { nível d'água } \\
& \text { para } \mathrm{t}=0, \mathrm{~h}=\text { nível estático; } \mathrm{H}=\text { nível d'água dinâmico). }
\end{aligned}
$$

\subsection{ENSAIO DE BOMBEAMENTO}

A fim de avaliar a intercomunicação dos poços de monitoramento situados no aquífero raso com os poços de produção situados no aquífero cristalino, foi realizado o bombeamento do antigo poço tubular P6 e o monitoramento dos níveis de água de três poços de monitoramento no aquífero raso (09B, 54, e 34), já existentes na unidade industrial, além do poço de monitoramento PP-01 instalado na rocha no atual trabalho. $O$ poço tubular $\mathrm{P} 6$ foi escolhido para bombeamento por ser o poço mais próximo existente nas imediações do poço PP-01, porém localizado fora da pluma de contaminação do aquífero raso.

O poço P6 possui profundidade de $150 \mathrm{~m}$ e, segundo seu perfil de instalação, a rocha se encontra a aproximadamente $29 \mathrm{~m}$. Nele foi instalado um revestimento de tudo liso de aço galvanizado até 39,5 $\mathrm{m}$ de profundidade, evitando assim a mistura de água do aquífero raso com o aquífero fraturado, e uma bomba submersa à 120 $\mathrm{m}$.

Para o ensaio, foi utilizada a bomba já existente no poço P6, sendo mantida uma vazão constante de bombeamento $(Q)$ e realizado $O$ acompanhamento das variações de níveis de água dos poços de observação por meio de medidores 
automáticos do tipo transdutores de pressão. Os poços monitorados e suas respectivas distâncias do poço de bombeamento P6 são apresentados na figura 32 .

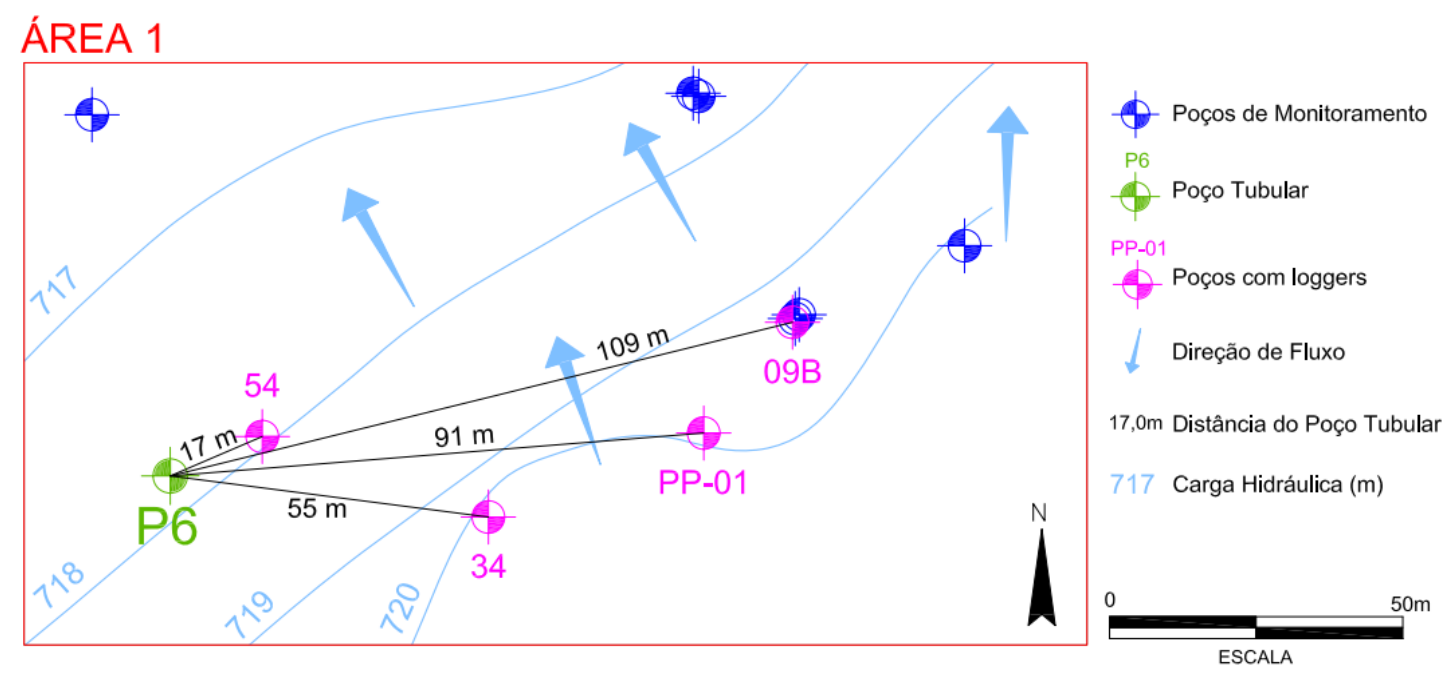

Figura 32 - Localização do Poço Tubular P6 utilizado para bombeamento e dos poços de monitoramento de nível de água - Área 1

O bombeamento do poço P6 teve início dia 5 de setembro às 6:25 horas sendo paralisado no mesmo dia às 17:45 horas, totalizando 11 horas e vinte minutos de bombeamento. O tempo máximo permitido de bombeamento por mês, segundo a outorga emitida do poço, é de apenas 12 horas por mês.

Os transdutores de pressão foram introduzidos nos poços de monitoramento no dia 02/09/2014 aproximadamente às 10h da manhã, quatro dias antes do bombeamento, e foram retirados dia 11/09, aproximadamente 5 dias após o término do bombeamento. Foram utilizados os transdutores de pressão das marcas Solinst e Diver e, durante esse período, foram registradas medições a cada $30 \mathrm{~min}$, a fim de avaliar a possíveis alterações nos níveis de água dos poços antes, durante, e após o bombeamento.

\subsection{Amostragem dos Poços de Monitoramento Instalados}

A água subterrânea dos poços de monitoramento PP-01 e PP-02 instalados na rocha foram posteriormente analisados durante a campanha de monitoramento geral, que foi realizada em novembro de 2013 e abril de 2014. A amostragem foi realizada através da técnica de baixa vazão (low flow) e seguiu as mesmas recomendações e procedimentos empregados na amostragem com obturadores, descritos em CETESB \& ANA (2011) e ASTM (2002). 
Após a medida do nível freático e da profundidade do poço, posicionou-se o tubo de coleta na altura da seção filtrante, controlando-se a vazão da bomba. Durante a purga, foi realizado o monitoramento da variação do nível d'água, $\mathrm{pH}$, condutividade elétrica, potencial de oxi-redução (Eh), temperatura e oxigênio dissolvido (OD) até sua estabilização, para posterior coleta das amostras em frascos apropriados.

As amostras água subterrânea coletadas foram devidamente preservadas e enviadas para o laboratório BioAgri Ambiental para análise de compostos orgânicos voláteis (VOCs).

\section{RESULTADOS}

\subsection{Análise Geológica e estrutural}

As áreas onde foram locadas as perfurações encontram-se na porção mais elevada do terreno, onde o topo rochoso se apresenta mais raso quando comparado com o restante da unidade industrial. A tabela 4 sumariza os principais dados das duas sondagens realizadas.

Tabela 5 - Dados das sondagens realizadas.

\begin{tabular}{|c|c|c|c|}
\hline $\begin{array}{c}\text { Sondagem / } \\
\text { Poço }\end{array}$ & $\begin{array}{c}\text { Espessura do } \\
\text { manto de } \\
\text { alteração * }(\mathbf{m})\end{array}$ & $\begin{array}{c}\text { Seção revestida } \\
\text { com tubo de 6" } \\
\text { (metros) }\end{array}$ & $\begin{array}{c}\text { Profundidade } \\
\text { perfurada (m) }\end{array}$ \\
\hline PP-01 & 39,5 & 44,87 & 78,0 \\
\hline PP-02 & 30,0 & 31,60 & 92,0 \\
\hline
\end{tabular}

${ }^{*}$ A espessura do manto de alteração corresponde à profundidade em que foi identificado o topo da rocha gnáissica local.

Através dos resultados obtidos com as perfilagens geofísicas, juntamente com a análise do material rochoso durante a perfuração, foi possível caracterizar com maior nível de detalhe o aquífero fraturado na unidade industrial. O perfil geológico das perfurações é apresentado na figura 33 e discutido a seguir. 


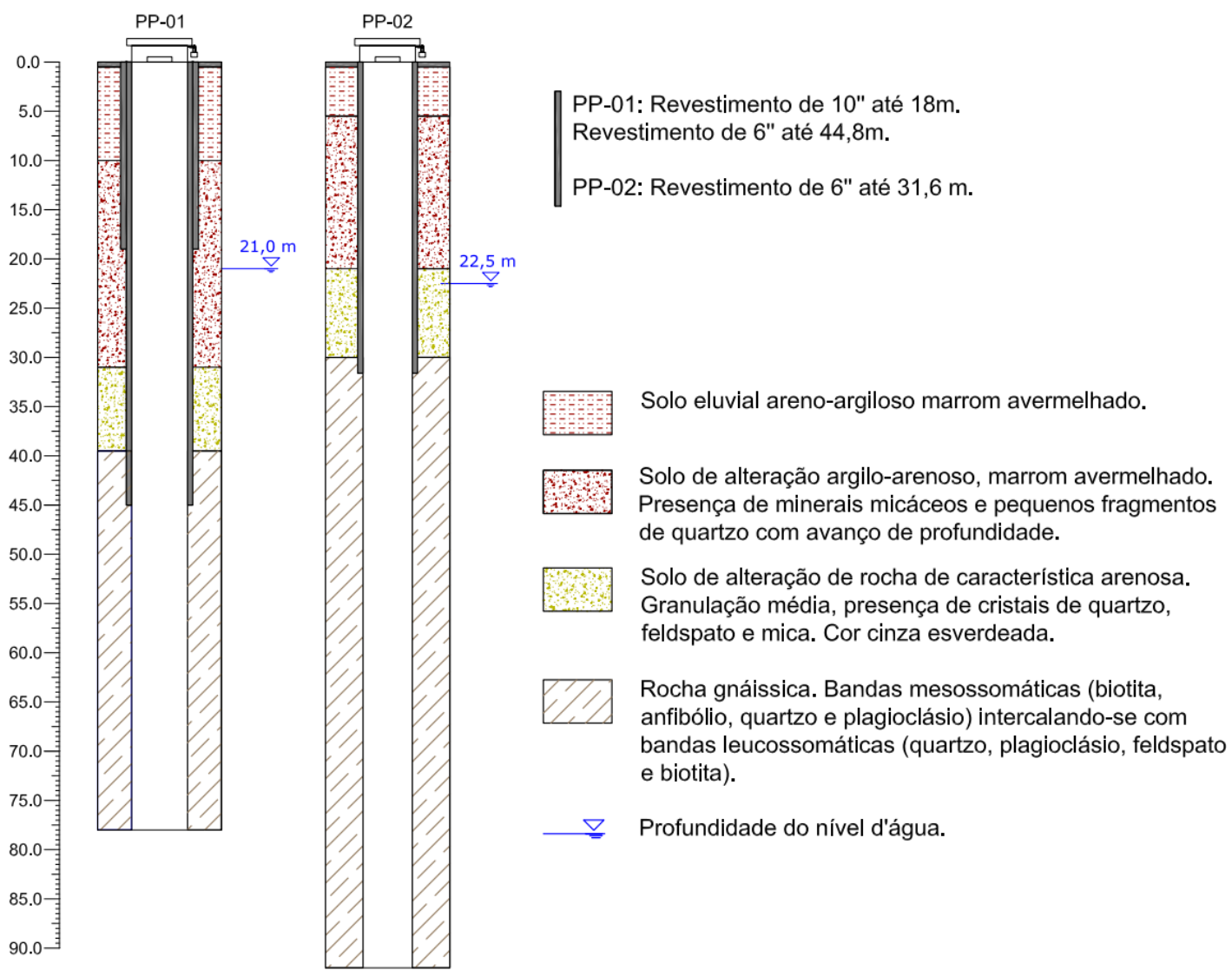

Figura 33 - Perfil litológico dos poços perfurados

A qualidade do selo de cimento do contato do revestimento com a rocha e as emendas dos tubos de revestimento pode ser verificada através da filmagem e da perfilagem cáliper e gama (Anexo 1), excluindo a possibilidade de infiltrações da água do aquífero raso para dentro do furo. A perfilagem cáliper mostrou um padrão retilíneo, indicando que não há variações no diâmetro da tubulação utilizada (6"), e os valores da radiação gama medidos na região dos revestimentos estão na ordem de 60 cps a 80 cps.

Durante a perfuração da rocha nos dois pontos investigados, o material coletado apresentou coloração cinza esverdeada nas porções mais superficiais alteradas e coloração cinza em profundidade, com presença de cristais de plagioclásio, quartzo e biotita.

Por meio da filmagem nos dois pontos perfurados, foi possível distinguir duas zonas faciológicas distintas na rocha gnáissica local. Do topo da rocha até a profundidade média de 65,0 metros predomina a porção mesossomática do gnaisse de coloração cinza escura, onde estão presentes minerais como biotita, hornblenda, 
anfibólio e feldspato alcalino. Após a profundidade de aproximadamente 65,0 metros, a rocha é caracterizada por porções leucossomáticas, de coloração esbranquiçada, formadas essencialmente por quartzo, feldspato alcalino e plagioclásio.

Considerando os resultados obtidos, é possível afirmar que o gnaisse local pertence à Unidade Ortognáissica Migmatítica Intermediária do Complexo SocorroGuaxupé. A figura 34 mostra a comparação e a semelhança do litotipo observado no ponto PP-02 com um afloramento representante da Unidade Migmatítica Intermediária próximo à unidade industrial.
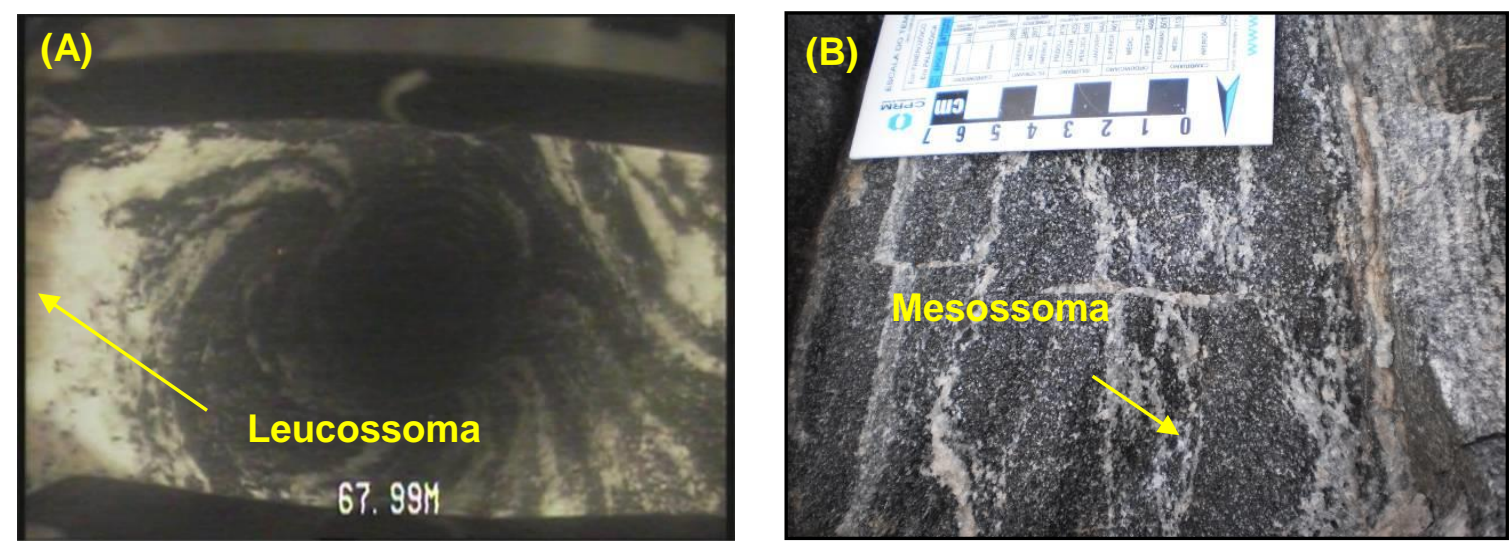

Figura 34 - (A) Rocha gnáissica encontrada na perfuração do PP-02; (B) Gnaisse migmatítico representante da Unidade Ortognáissica Migmatítica Intermediária do Complexo Socorro-Guaxupé

A filmagem dos pontos revelou ainda que no PP-01 e PP-02 a rocha gnáissica apresenta-se intensamente fraturada, em especial na porção mesossomática superior, próximo ao contato do manto de alteração com o topo rochoso. Durante a filmagem, foi possível notar ainda que, com o aumento da profundidade, a água do aquífero apresentou um aumento na turbidez, revelando que as fraturas em maior profundidade podem apresentar baixa transmissividade, causando uma estagnação do sistema e permitindo que os sedimentos se acumulem. Já em trechos onde a água é límpida, podem existir fraturas com maior saída e/ou entrada de água subterrânea.

Variações associadas à ocorrência de grandes fraturas foram registradas pela perfilagem cáliper no PP-01 entre 45,0 e 61,0 metros, sendo os trechos mais profundos caracterizados pela rocha mais íntegra, sem muitas estruturas, como mostra a figura 35 . 


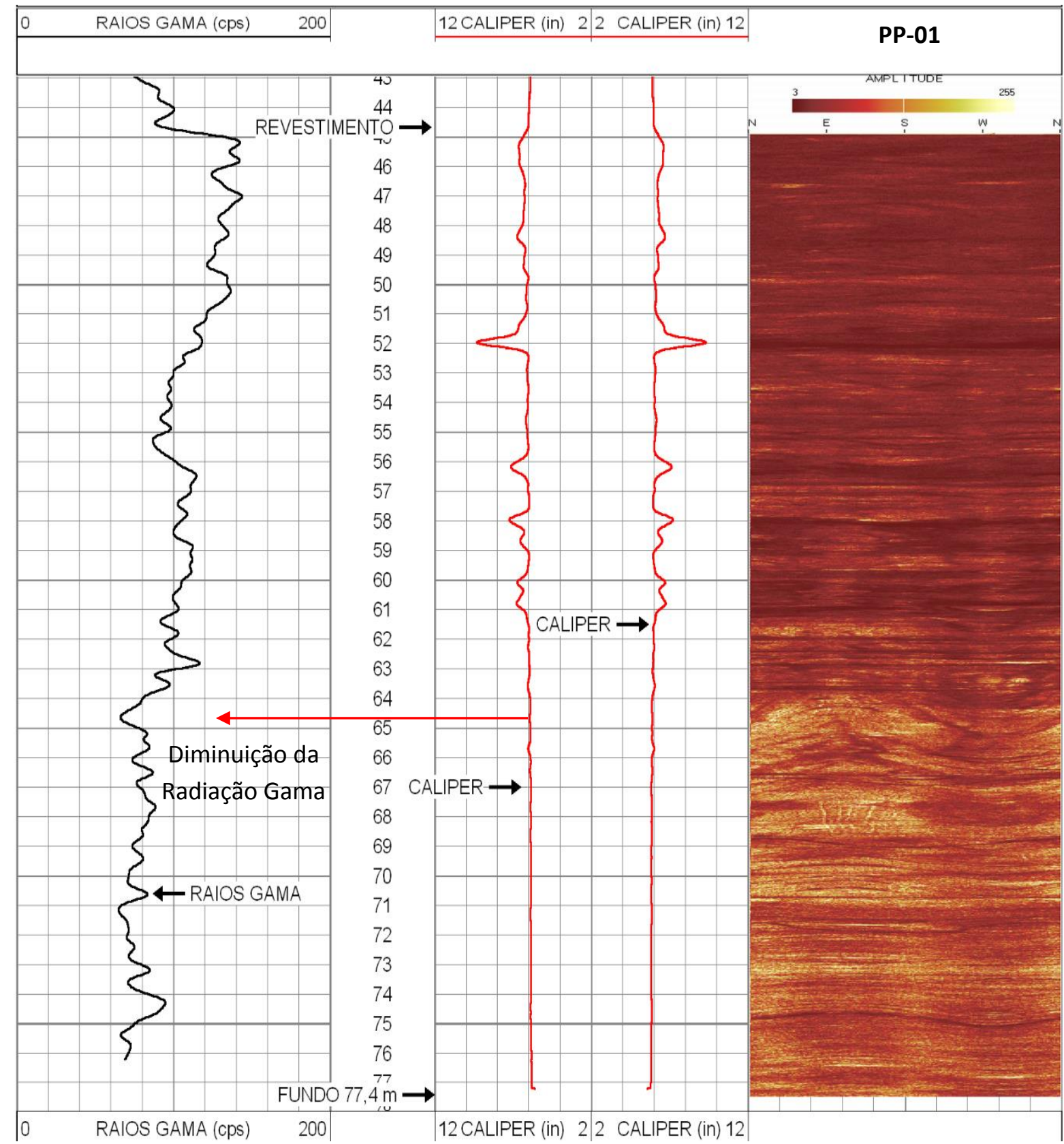

Figura 35 - Resultado da perfilagem cáliper e gama no ponto PP-01

A radiação gama na sondagem PP-01 apresentou valores médios entre 120 e 140 cps, até a profundidade aproximada de 64,0 metros, e valores menores, na ordem de $80 \mathrm{cps}$, após esta profundidade.

Os resultados da perfilagem cáliper na perfuração PP-02 (figura 36) mostram que as maiores fraturas se encontram espaçadas e presentes por todo o perfil, com zonas mais alteradas localizadas mais próximo da superfície. Os valores da radiação gama variam de 120 a 180 cps até a profundidade de aproximadamente 65,0 metros quando, assim como observado no ponto PP-01, há uma redução para valores entre 40 e 100 cps. 


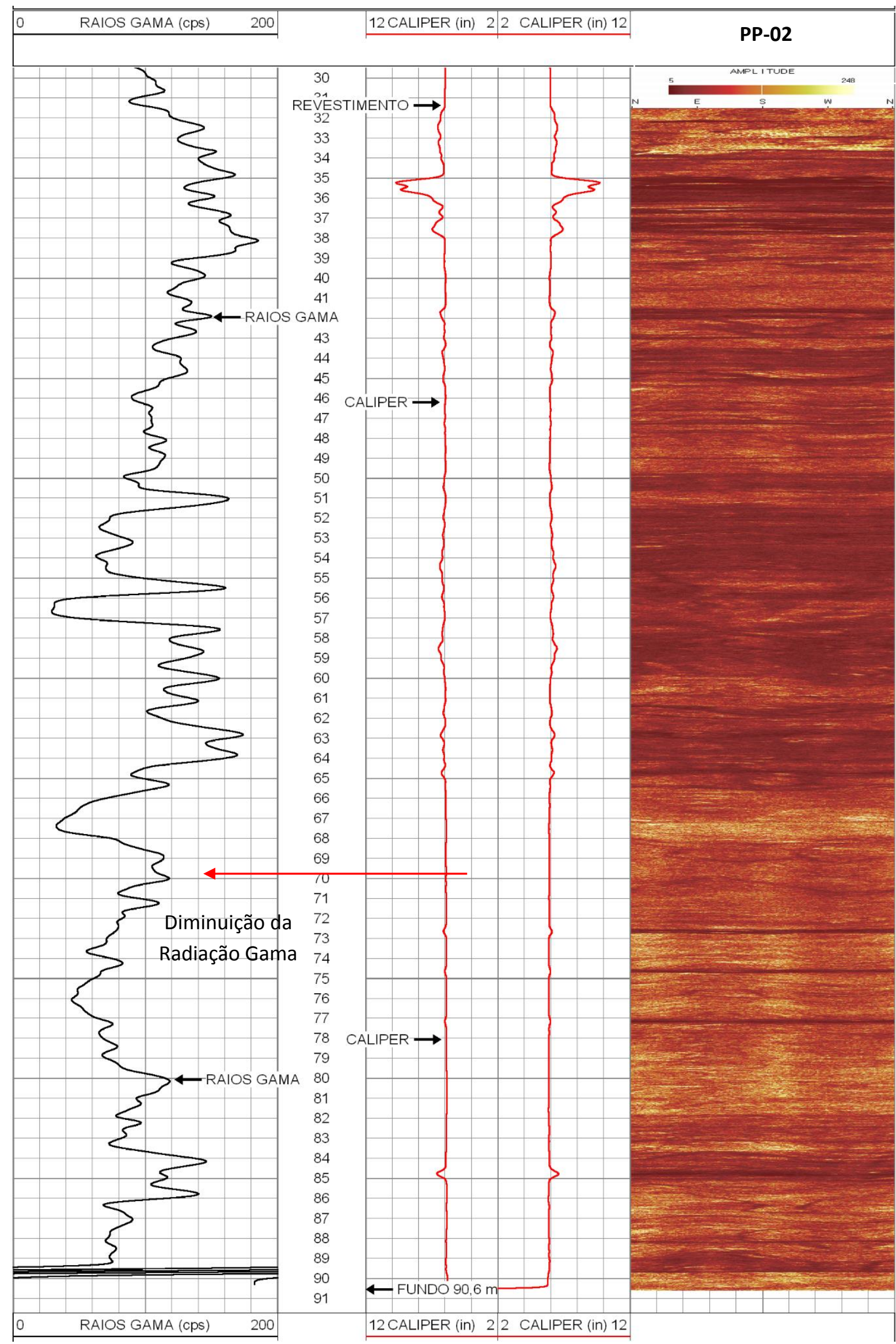

Figura 36 - Resultado da perfilagem cáliper e gama no ponto PP-02 
Em ambas as perfurações, o perfil de raios gama apresentou valores mais elevados na porção mais intemperizada, mesossomática do gnaisse (até aproximadamente $64 \mathrm{~m}$ no PP-01 e até $65 \mathrm{~m}$ no PP-02), composta por minerais ricos nos componentes $\mathrm{K}-\mathrm{U}-\mathrm{Th}$, como por exemplo feldspatos alcalinos e biotitas. Nesta porção, a rocha se encontra mais fraturada e alterada e a elevação dos raios gama está diretamente relacionada com a maior presença de argilominerais provenientes da rocha. A ocorrência de fraturas na porção mesossomática pode ser favorecida pela presença de minerais micáceos orientados, que se alteram com maior facilidade, podendo gerar zonas de fraqueza.

$\mathrm{Na}$ porção leucossomática mais profunda (abaixo dos $65,0 \mathrm{~m}$ ), a rocha se encontra mais íntegra, com menor quantidade de fraturas e diminuição da média de emissão de raios gama. Além disso, a presença de quartzo e plagioclásio pode ainda contribuir para a redução dos raios gama em profundidade. Na rocha fresca menos alterada, os picos de raios gama observados foram relacionados aos veios mais claros, provavelmente devido à presença de feldspato alcalino. Nessa porção, onde há o predomínio de minerais mais escuros, observa-se uma redução da emissão dos raios gama.

Através dos dados obtidos pela perfilagem acústica, foi possível identificar e caracterizar as feições de Fraturas, Possíveis Fraturas e Foliações em cada um dos pontos analisados. Os dados de profundidade e atitude (direção e mergulho) das feições traçadas são apresentados no Anexo 2 e foram tratados em diagrama de rosetas, histogramas e estereogramas, auxiliando na definição dos diferentes grupos de fraturas. Importante ressaltar que o comprimento das fraturas e sua interconectividade não podem ser identificados por esse método geofísico.

São também apresentados os contornos de densidade corrigidos pelo método de Terzaghi (1965) para análise de densidade e espaçamento dos grupos identificados.

Nos estereogramas (figuras 37 e 40) as feições duvidosas, caracterizadas como "Possíveis Fraturas", foram representadas em pontos azuis, a fim de facilitar a avaliação de sua importância e coerência com relação às "Fraturas", representadas em vermelho e utilizadas prioritariamente para a separação dos principais grupos. As medidas de Foliação são representadas em preto. 


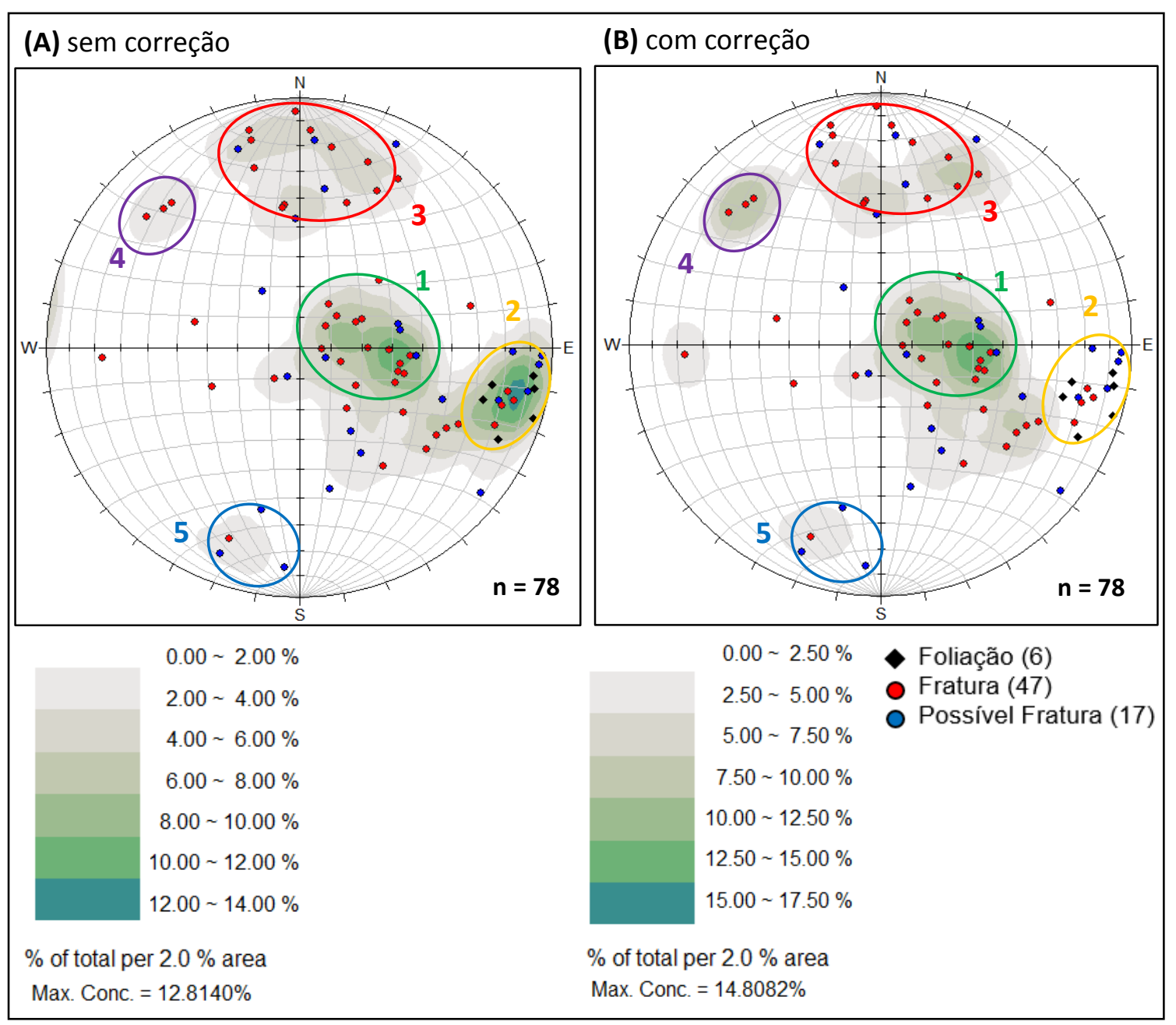

Figura 37 - Projeções polares dos planos de fraturas presentes no ponto PP-01 e grupos de fraturas identificados (A) sem aplicação da correção de Terzaghi, (B) com correção de Terzaghi

Conforme pode ser observado, a maioria dos pontos em azul, indicativos de Possíveis Fraturas, apresentam distribuição semelhante às feições de Fraturas (em vermelho), contribuindo para o adensamento dos principais grupos verificados, sendo assim consideradas na análise estrutural. As principais direções e mergulho das feições traçadas são apresentas na figura 38. Ainda, a fim de auxiliar na interpretação das principais direções e mergulhos, foi elaborado para cada grupo o estereograma com os círculos máximos, apresentados na figura 39. 


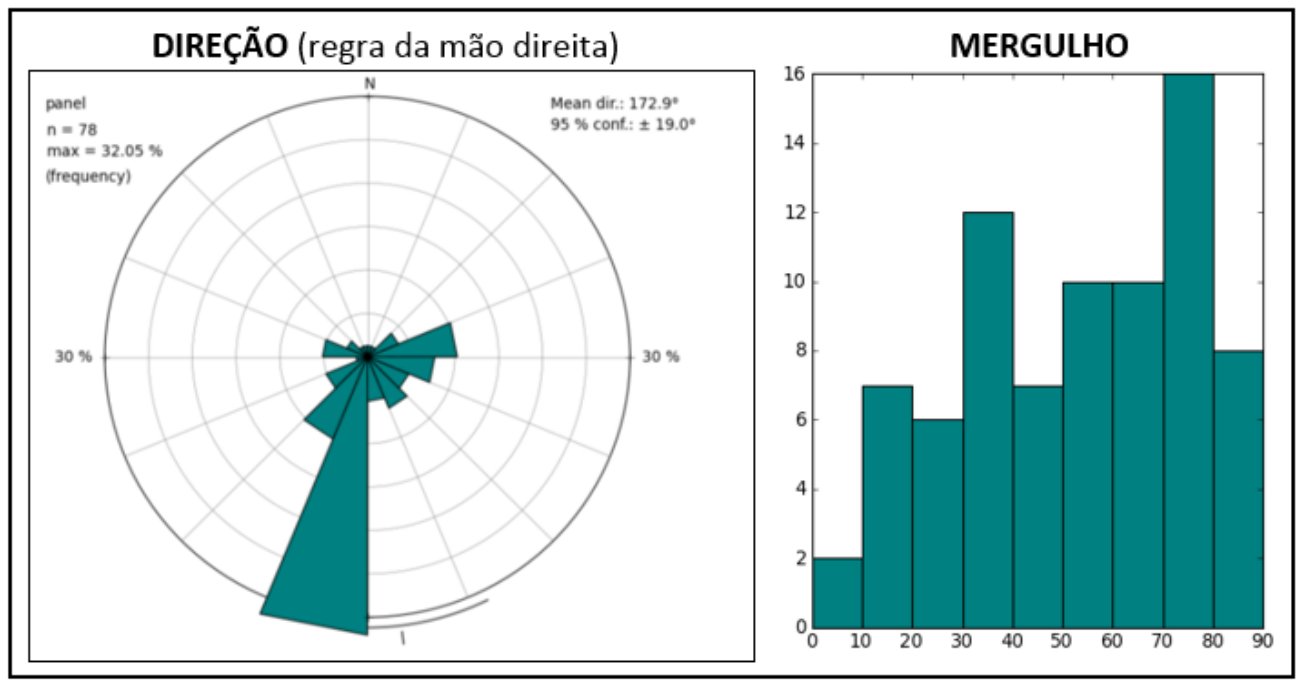

Figura 38 - Diagrama de roseta mostrando as principais direções e histograma dos ângulos de mergulhos dos planos de fraturamento no ponto PP-01

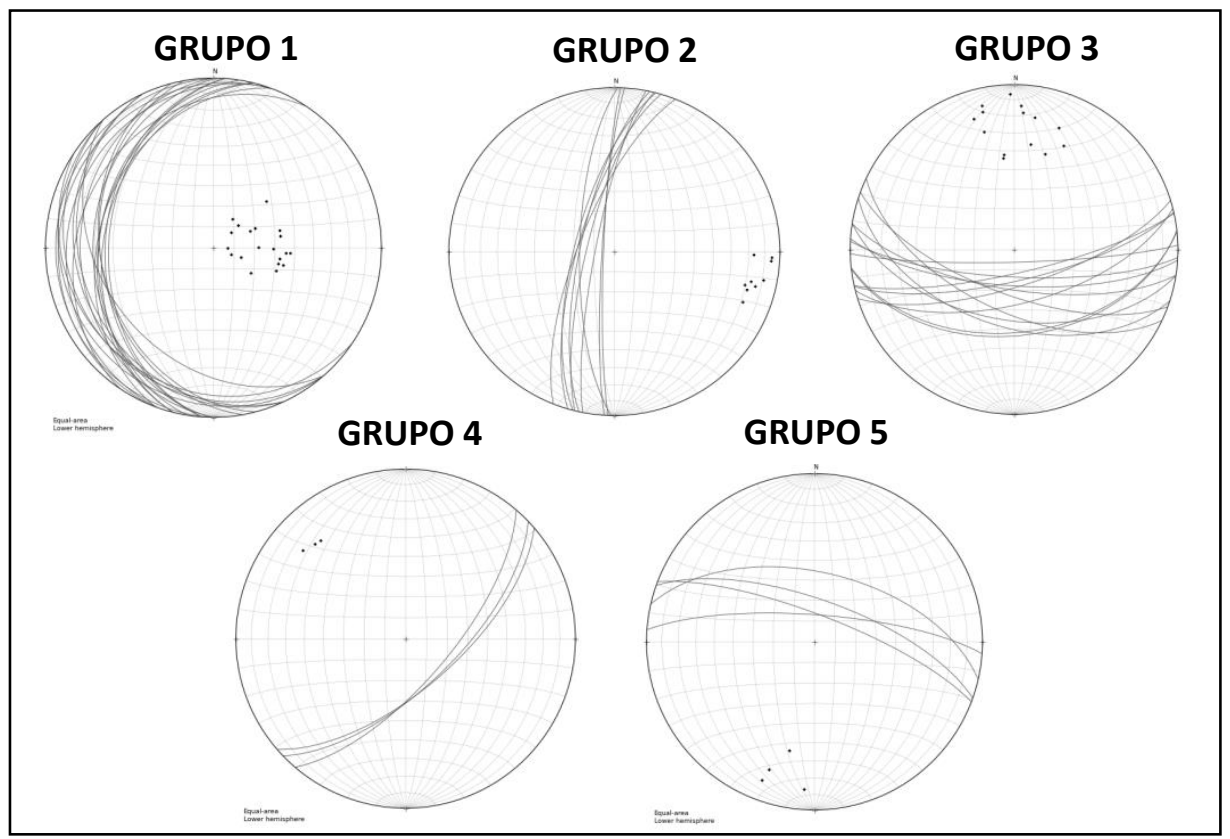

Figura 39 - Círculos Máximos dos principais Grupos de Fraturas identificados no PP-01

Mais de $30 \%$ das feições levantadas no PP-01, incluindo as medidas de Foliação, possuem direção principal norte-sul, variando entre N0-25E. É expressiva ainda a quantidade de fraturas identificadas paralelas às foliações, que possuem mergulhos subverticais. Importante lembrar que as fraturas de elevado ângulo são mais difíceis de serem amostradas e podem estar subestimadas.

A análise da perfilagem cáliper juntamente com a acústica, possibilitou a identificação de uma zona intensamente fraturada no trecho compreendido entre 52 e 64 metros. 
As densidades corrigidas das feições de fraturas dos principais grupos identificados são apresentadas na tabela 6 , juntamente com o ângulo médio e direção preferencial de cada grupo.

Tabela 6: Quantidade de fraturas corrigidas pela aplicação do método de Terzaghi (1965) para cada grupo de fraturas identificado no ponto PP-01.

\begin{tabular}{|c|c|c|c|c|c|c|}
\hline Ponto & Grupo & $\begin{array}{c}\text { Mergulho } \\
\text { médio das } \\
\text { Fraturas }\end{array}$ & $\begin{array}{c}\text { Direção } \\
\text { principal }\end{array}$ & $\begin{array}{c}\text { Quantida } \\
\text { de de } \\
\text { Fraturas }\end{array}$ & $\begin{array}{c}\text { Fraturas } \\
\text { com a>20 }\end{array}$ & $\begin{array}{c}\text { Quant. Fraturas - } \\
\text { Correção Terzaghi }\end{array}$ \\
\hline \multirow{3}{*}{ PP-01 } & GRUPO 1 & 24,794 & N-S & 20 & 20 & 22,48 \\
\cline { 2 - 7 } & GRUPO 2 & 76,28 & NNE-SSW & 9 & 0 & 0 \\
\cline { 2 - 7 } & GRUPO 3 & 65,49 & E-W & 14 & 7 & 13,06 \\
\cline { 2 - 7 } & GRUPO 4 & 66,94 & NE-SW & 3 & 3 & 7,69 \\
\cline { 2 - 7 } & GRUPO 5 & 69,83 & WNW-ESE & 4 & 2 & 4,65 \\
\hline
\end{tabular}

Uma vez que a avaliação do perfil da rocha indicou duas regiões faciológicas distintas, foram também elaborados diferentes estereogramas para cada uma delas (figura 40) a fim de avaliar a influência da profundidade na propagação dos esforços e geração das fraturas.

Analisando os dados apresentados é possível identificar pelo menos 5 grupos de fraturas principais, descritos a seguir.

Grupo 1: Fraturas com ângulo de mergulho inferior a $40^{\circ}$ (baixo ângulo), preferencialmente para $\mathrm{W}$, com pequenas variações para SW ou NW. Apresenta direções predominantes variando entre N45W a N30E. Este é o principal grupo de fraturas identificado e apresenta estruturas possivelmente abertas que estão presentes principalmente na porção mesossomática mais alterada do gnaisse, que vai aproximadamente dos 45,0 aos 64,0 metros de profundidade. O grupo é pouco influenciado pela aplicação da correção de Terzaghi, visto que as feições observadas possuem baixo ângulo de mergulho, sendo interceptadas pelo furo com um ângulo $\alpha>60^{\circ}$. 


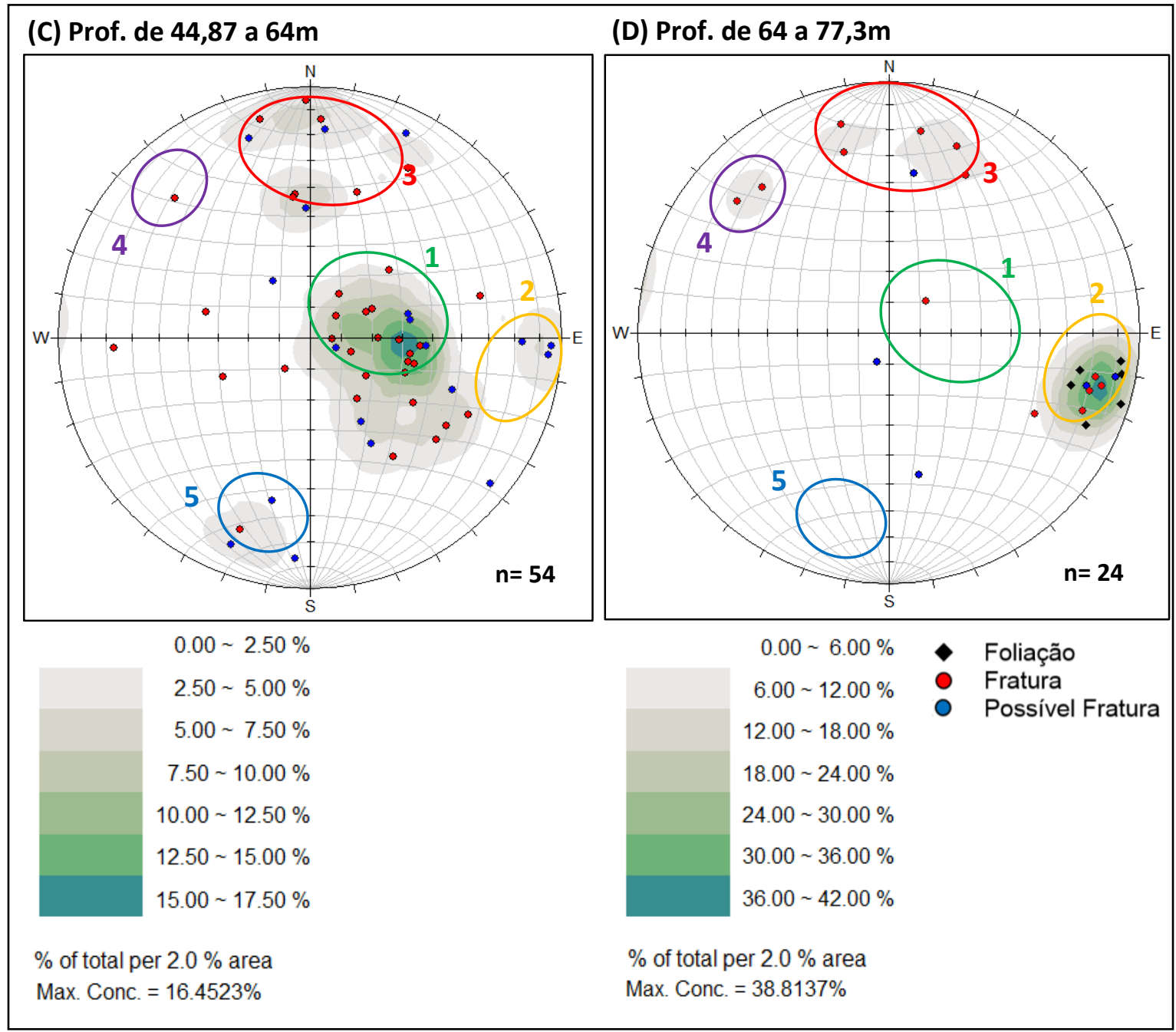

Figura 40 - Estereogramas com contornos de densidade das feições observadas em diferentes profundidades no PP-01

Grupo 2: Estruturas paralelas à foliação, de direção N0-22E (vertical) com elevado ângulo de mergulho ( $>60^{\circ}$ ) para W. O Grupo 2 é o segundo grupo de maior importância. As fraturas são observadas a partir de $58 \mathrm{~m}$ de profundidade sendo mais expressivas na porção leucossomática, abaixo de 64 m com direção entre N025E. As "Possíveis Fraturas" identificadas neste grupo estão presentes na zona de transição da porção mesossomática para a porção leucossomática. Importante notar que, devido ao elevado ângulo de mergulho (baixos valores de $\alpha$ ), as fraturas do grupo 2 não são consideradas na correção de Terzaghi, e a quantidade de feições observadas está possivelmente subestimada.

Grupo 3: Fraturas de direção principal E-W (leste - oeste) e mergulho com ângulo $>45^{\circ}$ preferencialmente para Sul, entre os Azimutes N160 e N205. Fraturas desse grupo são verificadas espaçadas ao longo de todo o perfil da perfuração. 
Neste grupo, somente as feições observadas com ângulos de mergulho entre $45^{\circ} \mathrm{e}$ 70ํ são corrigidas pelo método de Terzaghi. Deste modo, na figura 37 observa-se um aumento da densidade das fraturas de ângulos médios ao passo que as fraturas com mergulhos subverticais não são consideradas pela correção.

Grupo 4: de direção NE-SW e mergulho entre 60 e $70^{\circ}$ para SE. São verificadas somente 3 feições representativas desse grupo nas profundidades de 54, 72 e 73 m porém o grupo se torna mais expressivo após a aplicação de Terzaghi.

Grupo 5: de direção W a WNW (Leste - Oeste) com ângulo de mergulho >55은 para N. As feições são observadas somente na porção superior da rocha, até $55 \mathrm{~m}$ de profundidade. Assim como verificado no Grupo 3, somente fraturas com ângulos entre 55 e $70^{\circ}$ são influenciadas pela correção.

Para análise da densidade e espaçamento das fraturas, utilizou-se o programa WellCad onde as feições de cada um dos grupos foram separadas, a fim de facilitar sua classificação. Conforme mencionado, as fraturas de um mesmo grupo podem ser classificadas em aleatória, distribuição regular, distribuição regular variada, ou concentrada. O espaçamento dos diferentes grupos é apresentado no Anexo 3 e os dados resumidos na tabela 7 .

Tabela 7 - Tipo de espaçamento, distribuição de densidade e espaçamento médio das fraturas no PP-01 após a aplicação da correção de Terzaghi.

\begin{tabular}{|c|c|c|c|c|c|}
\hline Grupo & $\begin{array}{c}\text { Total } \\
\text { fraturas }\end{array}$ & $\begin{array}{c}\text { Tipo de } \\
\text { Espaçamento }\end{array}$ & $\begin{array}{c}\text { Intervalo de } \\
\text { ocorrência das } \\
\text { fraturas }\end{array}$ & $\begin{array}{c}\text { Densidade } \\
\text { média }\end{array}$ & $\begin{array}{c}\text { Espaçamento } \\
\text { médio }(\mathbf{m})\end{array}$ \\
\hline GRUPO 1 & 22,48 & Aleatório & $\begin{array}{c}\text { Concentrada de } 44,7 \\
\text { até } 64,0 \mathrm{~m} .\end{array}$ & 1,18 & 0,85 \\
\hline GRUPO 2 & 9 & Regular variável & De 57,0 a $78,0 \mathrm{~m}$ & 0,43 & 2,33 \\
\hline GRUPO 3 & 20,06 & Regular variável & De 44,87 até $64,0 \mathrm{~m}$. & 0,61 & 1,65 \\
\cline { 3 - 6 } & Regular concentrada & De 64,0 a $78,0 \mathrm{~m}$ & Por todo o trecho \\
perfilado & 0,23 & 4,31 \\
\hline GRUPO 4 & 7,69 & Aleatório & Até $61,0 \mathrm{~m}$ & 0,41 & 2,43 \\
\hline
\end{tabular}

O Grupo 1, de distribuição aleatória, é o de maior densidade e menor espaçamento médio, quando considerada sua presença preferencialmente na porção superior do maciço. Já o Grupo 3 apresenta diferentes formas de distribuição e as fraturas se apresentam geralmente agrupadas. Assim o espaçamento das feições será maior dependendo da quantidade de fraturas identificadas na mesma 
profundidade.

Os dados obtidos para o PP-02 são apresentados nas figuras 41, 42 e 43, sendo discutidos a seguir.

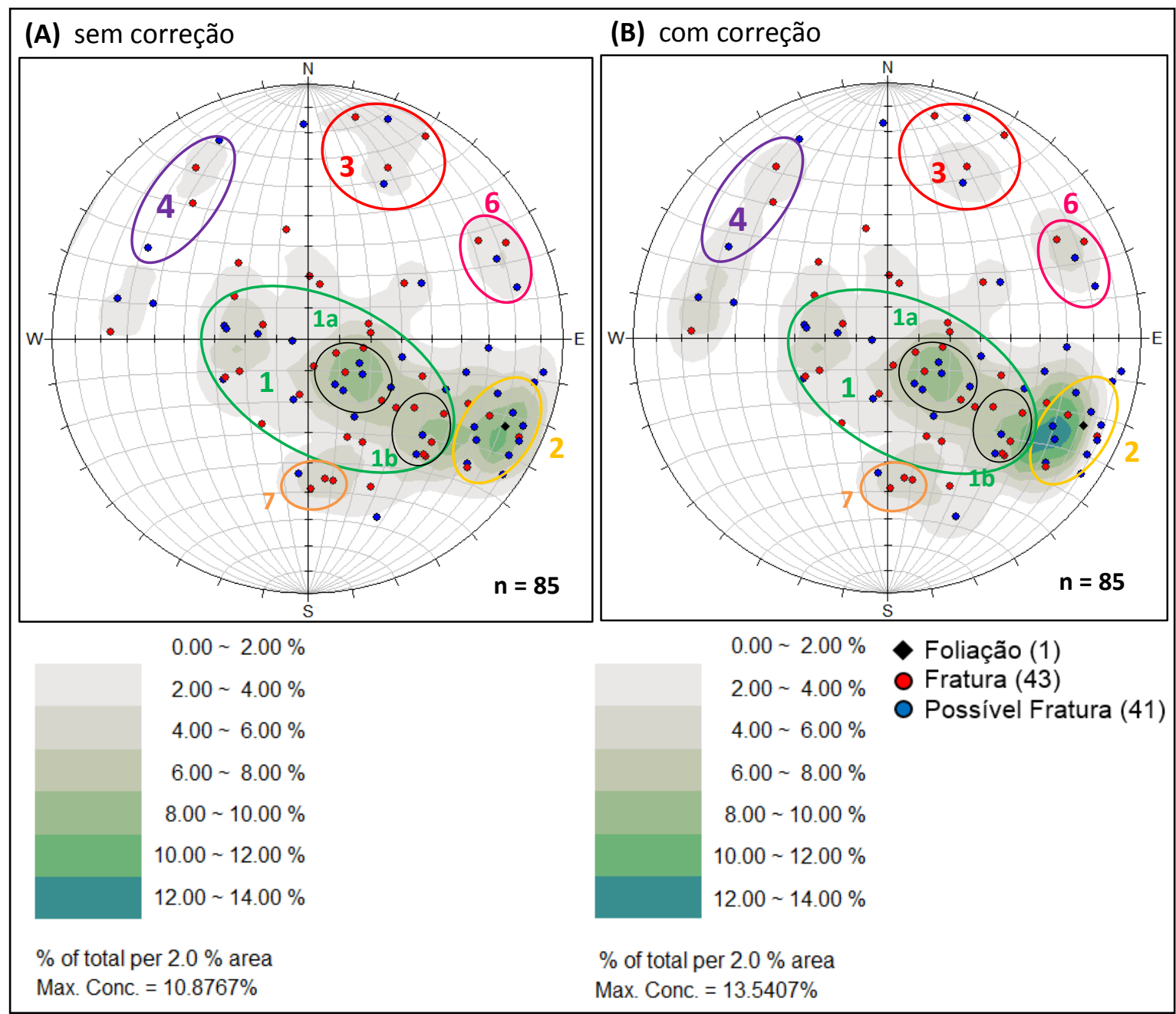

Figura 41 - Projeções polares dos planos de fraturamento presentes no ponto PP-02 (A) sem aplicação da correção de Terzaghi, (B) com correção de Terzaghi

$\mathrm{Na}$ avaliação dos dados do ponto PP-02, verifica-se que as feições identificadas se apresentam mais dispersas e a quantidade de "Possíveis Fraturas" representa quase $50 \%$ do total levantado, devendo ser consideradas com cautela, avaliando prioritariamente as feições de "Fraturas". As principais direções e mergulho dos grupos são apresentados nas Figuras 42 e 43 e as densidades corrigidas pelo método de Terzaghi são apresentadas na Tabela 8. 


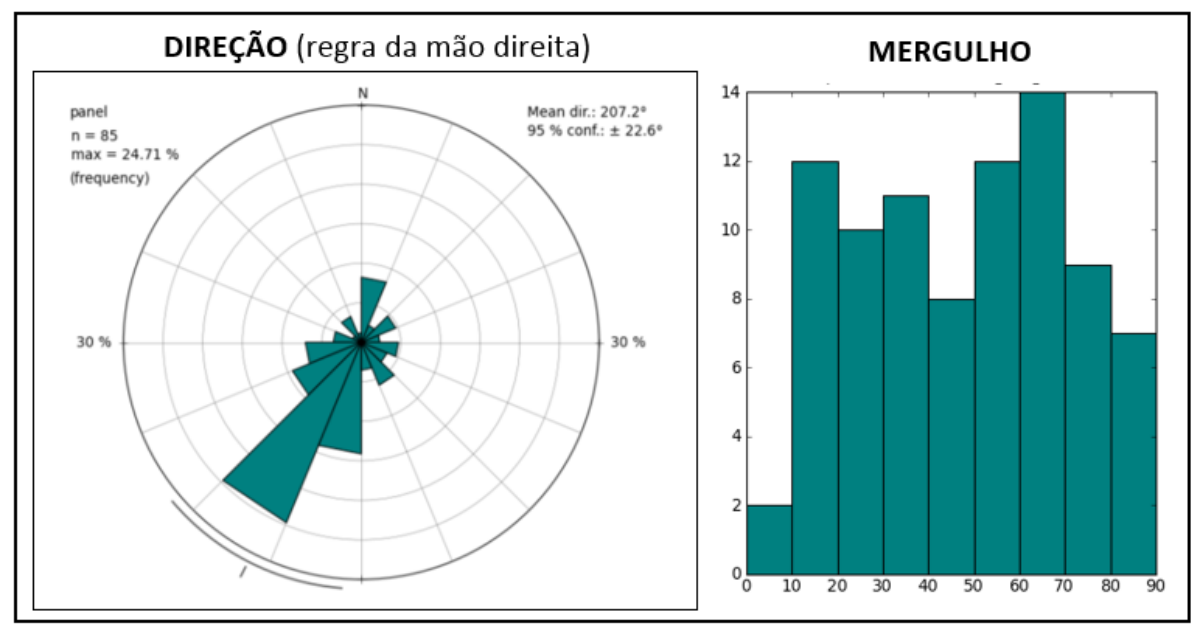

Figura 42 - Diagrama de roseta mostrando as principais direções e histograma dos ângulos de mergulhos dos planos de fraturamento no ponto PP-02

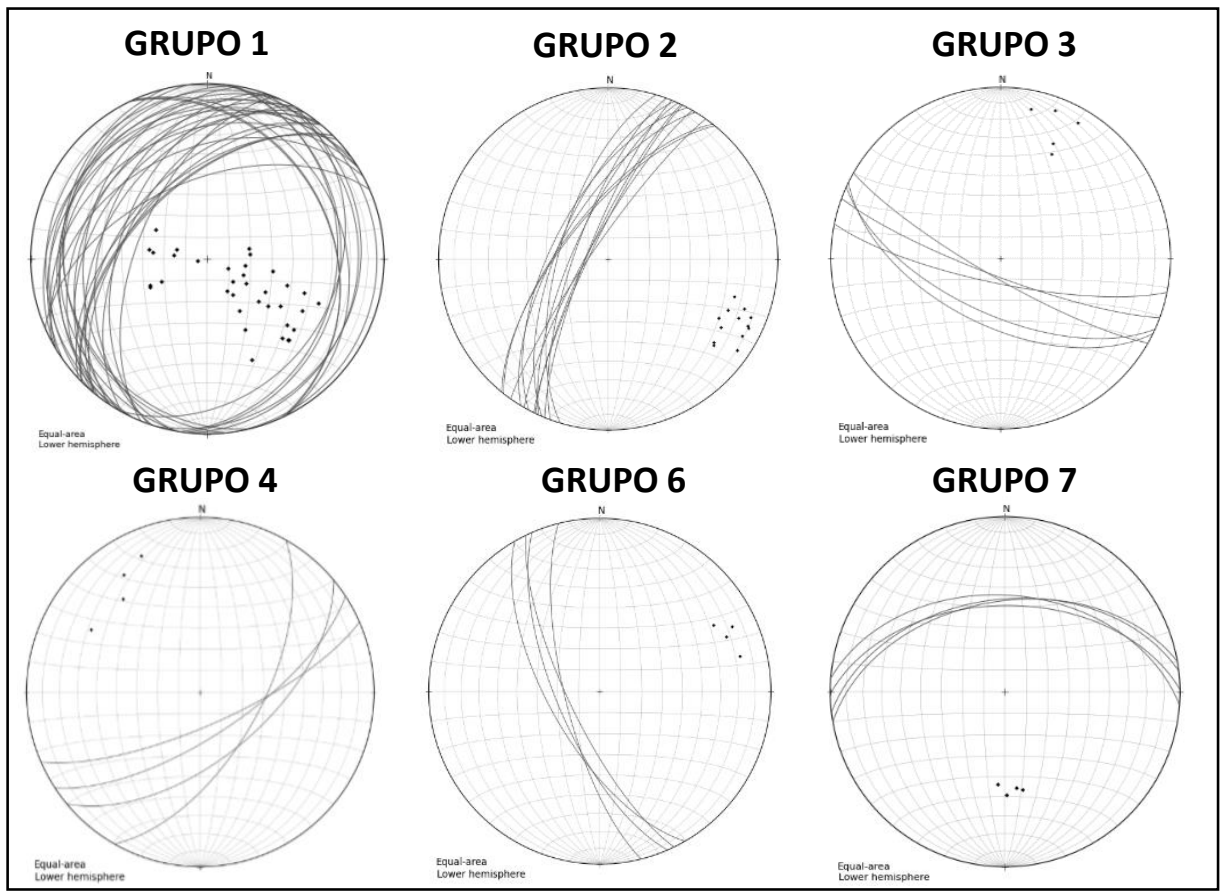

Figura 43 - Círculos Máximos dos principais Grupos de Fraturas identificados no PP-02

Tabela 8 - Quantidade de fraturas corrigidas pela aplicação do método de Terzaghi (1965) para cada grupo de fraturas identificado no ponto PP-02.

\begin{tabular}{|c|c|c|c|c|c|c|}
\hline Ponto & Grupo & $\begin{array}{c}\text { Mergulho } \\
\text { médio }\end{array}$ & $\begin{array}{c}\text { Direção } \\
\text { principal }\end{array}$ & $\begin{array}{c}\text { Quantidade } \\
\text { de Fraturas }\end{array}$ & $\begin{array}{c}\text { Fraturas } \\
\text { com a>20 }\end{array}$ & $\begin{array}{c}\text { Quant. Fraturas - } \\
\text { Correção Terzaghi }\end{array}$ \\
\hline \multirow{7}{*}{ PP-02 } & GRUPO 1a & 19,13 & NEE-SSW & 9 & 9 & 9,67 \\
\cline { 2 - 7 } & GRUPO 1b & 50,87 & NE-SW & 7 & 7 & 11,22 \\
\cline { 2 - 7 } & GRUPO 2 & 72,97 & NE-SW & 12 & 6 & 15,06 \\
\cline { 2 - 7 } & GRUPO 3 & 72,03 & WNW-ESE & 5 & 2 & 4,05 \\
\cline { 2 - 7 } & GRUPO 4 & 65,94 & NE-SW & 4 & 3 & 6,86 \\
\cline { 2 - 7 } & GRUPO 6 & 70,71 & NW-SE & 4 & 2 & 5,24 \\
\cline { 2 - 7 } & GRUPO 7 & 46,67 & E-W & 4 & 4 & 5,84 \\
\hline
\end{tabular}


No PP-02, 40\% das feições observadas possuem direção NE-SW, representadas principalmente por fraturas dos Grupos 1, 2 e 4. A medida de foliação também apresenta essa direção.

Os estereogramas com contornos de densidade elaborados para as diferentes profundidades auxiliam na identificação dos principais grupos de fraturas. Apesar de mais dispersos, alguns grupos apresentam semelhanças com os identificados no PP-01, conforme pode ser visualizado na Figura 44.

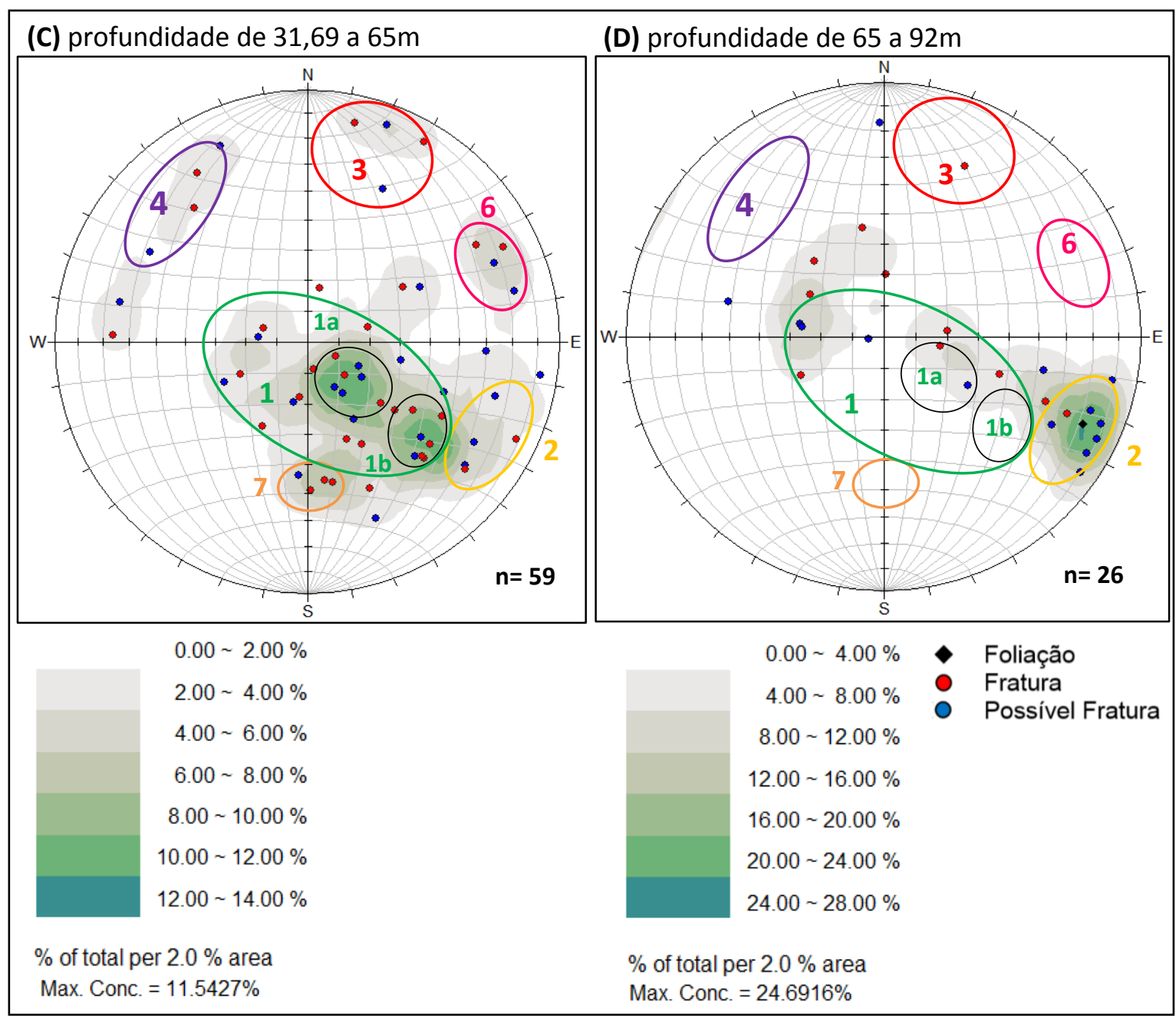

Figura 44 - Estereogramas com contornos de densidade das feições observadas em diferentes profundidades no PP-02

O Grupo 1 é caracterizado neste ponto por baixos a médios ângulos de mergulho $\left(<60^{\circ}\right)$ e com direção dispersa mas predominante para NNE-SW e mergulho para WNW. É o grupo mais abundante, sendo possível verificar duas áreas mais marcantes pela distribuição das densidades. Esse grupo possui direção 
variando entre N30W e N60E, sendo o subgrupo 1-a caracterizado por baixos ângulos de mergulho (até $3^{\circ}$ ) e o subgrupo 1-b com ângulos médios de mergulho (entre 40 e $60^{\circ}$ ).

Assim como na sondagem PP-01, as fraturas do Grupo 1 ocorrem com mais frequência na porção mesossomática do gnaisse (até aproximadamente $65 \mathrm{~m}$ ), porém são verificadas feições dispersas até o final da perfuração. A aplicação da correção de Terzaghi pouco influenciou na contagem das fraturas de baixo ângulo de mergulho (subgrupos 1-a), sendo mais significativa nos subgrupos 1-b, que apresentam mergulhos entre $40^{\circ}$ e $60^{\circ}$.

O Grupo 2, também observado no PP-01, apresenta direção N a NE (N15-45E) e mergulhos para W a NW com ângulos mais elevados, entre 60 e 85․ Nos estereogramas com contornos de densidade elaborados para as diferentes profundidades, fica mais clara a divisão das fraturas do Grupo $2 \mathrm{com}$ as fraturas do Grupo 1 de médio ângulo de mergulho, visto que os dois grupos apresentam a mesma direção e sentido de mergulho. As fraturas do Grupo 2, são paralelas à foliação e, apesar de ocorrerem por todo o trecho perfurado, são mais expressivas em profundidade. A aplicação da correção de Terzaghi neste grupo é pouco representativa, uma vez que considera apenas as fraturas com ângulo de mergulho $<70^{\circ}$, que representam $50 \%$ das feições identificadas. Ainda assim é o segundo grupo mais importante.

As fraturas do Grupo 3 possuem direção entre N60-80W e mergulho para S a SW com ângulos maiores que 55‥ Ocorrem na porção mais rasa mesossomática da rocha. As fraturas do Grupo 4 são pouco expressivas no PP-02 e possuem direção NE-SW e mergulhos entre 55 e 75ำ para SE.

Fraturas do Grupo 5 não foram identificadas nesta perfuração, porém são observados ainda dois novos grupos de fraturas. O Grupo 6 possui direção entre N10-30W e mergulho para SW com ângulo entre 50 e 70․ Fraturas de direção Leste-Oeste e ângulo de mergulho entre $40^{\circ}$ e $50^{\circ}$ para $\mathrm{N}$ foram classificadas como Grupo 7.

Os grupos de fratura 3, 4 e 6 também são pouco influenciados pela correção de Terzaghi, devido às feições de elevado ângulo de mergulho que não são consideradas. Outras feições de direção e mergulho variado perfazem quase $30 \%$ do total identificado.

A perfilagem HRAT do ponto PP-02 revelou que há uma intercalação entre 
fraturas possivelmente abertas e fraturas sem abertura. A porção mais profunda apresenta a maior quantidade de fraturas aparentemente sem aberturas e as fraturas com possíveis aberturas, possuem ângulo de mergulho $<40^{\circ}$. Os trechos compreendidos entre os intervalos de 35 a 43 metros e entre 62 e 73 metros representam zonas intensamente fraturadas, que podem ser favoráveis à percolação de água.

Avaliando-se os diferentes grupos de fraturas do PP-02, não é possível identificar um padrão regular de distribuição, sendo assim classificados como aleatórios. Para o cálculo de densidade e espaçamento médio, apresentado na Tabela 9, foi levado em consideração a porção do maciço em que as fraturas de cada Grupo são identificadas.

Tabela 9 - Tipo de espaçamento, distribuição de densidade e espaçamento médio das fraturas no PP-02 após a aplicação da correção de Terzaghi.

\begin{tabular}{|c|c|c|c|c|c|}
\hline Grupo & $\begin{array}{c}\text { Total } \\
\text { fraturas }\end{array}$ & $\begin{array}{c}\text { Tipo de } \\
\text { espaçamento }\end{array}$ & $\begin{array}{l}\text { Intervalo de } \\
\text { ocorrência das } \\
\text { fraturas }\end{array}$ & $\begin{array}{l}\text { Densidade } \\
\text { média }\end{array}$ & $\begin{array}{l}\text { Espaçamento } \\
\text { médio }(\mathrm{m})\end{array}$ \\
\hline GRUPO 1a & 9,67 & Aleatório & \multirow{2}{*}{ De 31,60 à 92,0 m. } & \multirow{2}{*}{0,35} & \multirow{2}{*}{2,89} \\
\hline GRUPO 1b & 11,22 & Aleatório & & & \\
\hline GRUPO 2 & 21,06 & Aleatório & De 42 a $92,0 \mathrm{~m}$ & 0,42 & 2,37 \\
\hline GRUPO 3 & 7,05 & Aleatório & De 31,6 a 65,0 m & 0,21 & 4,74 \\
\hline GRUPO 4 & 7,86 & Aleatório & De 31,6 a $65,0 \mathrm{~m}$ & 0,24 & 4,25 \\
\hline GRUPO 6 & 7,24 & Aleatório & De 31,6 a 65,0 m & 0,22 & 4,61 \\
\hline GRUPO 7 & 5,84 & Aleatório & De 31,6 a $65,0 \mathrm{~m}$ & 0,17 & 5,72 \\
\hline
\end{tabular}

A maior densidade e menor espaçamento ocorre nas fraturas do Grupo 2, seguido das fraturas do Grupo 1, que possuem neste ponto baixo a médio ângulos de mergulho. Pela distribuição das fraturas apresentadas no Anexo 3, é possível observar ainda que grande parte das fraturas estão concentradas até aproximadamente $65 \mathrm{~m}$ de profundidade.

No poço tubular $\mathrm{P5}$, os resultados da perfilagem HRAT revelaram uma pequena diferença na distribuição das famílias de fraturas quando comparados com as perfurações PP-01 e PP-02. Importante ressaltar que no P5 foi realizada somente a perfilagem acústica, não sendo possível confirmar algumas feições de "Possíveis Fraturas" através da utilização de outras técnicas de perfilagem, conforme executado nos pontos PP-01 e PP-02. Os dados estruturais deste poço são analisados nas Figuras 45, 46 e 47 e densidade das fraturas na tabela 10. Os dados 
de fraturas possivelmente abertas foram obtidos através da análise do perfil acústico.

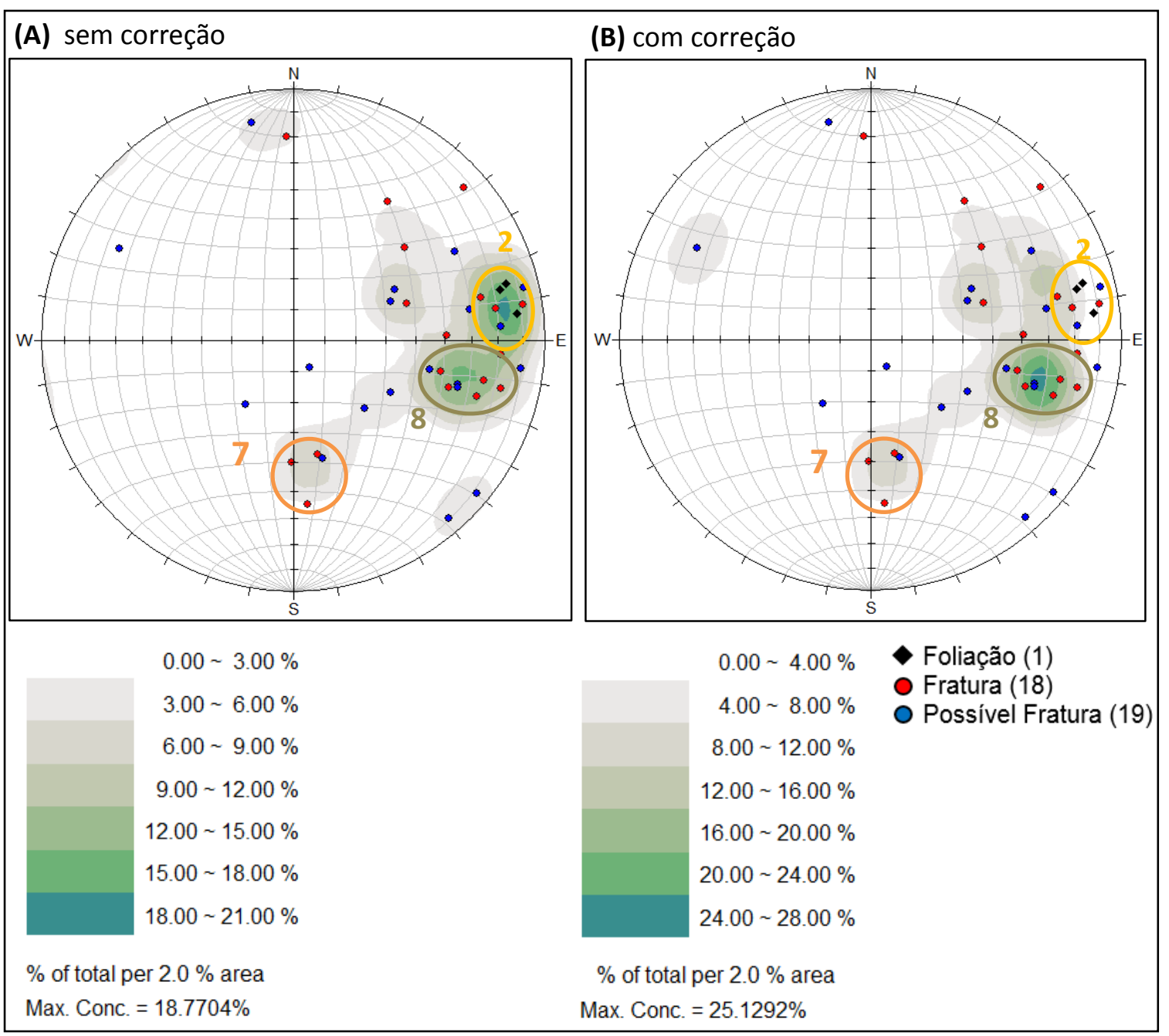

Figura 45 - Projeções polares dos planos de fraturamento presentes no ponto P5 (a) sem aplicação da correção de Terzaghi, b) com correção de Terzaghi

Os principais grupos foram identificados levando-se em consideração as feições classificadas como "Fraturas", sendo possível observar pontos azuis dispersos em áreas sem adensamento e que não foram considerados.

A maior parte das fraturas do P5 possuem direção N-S com mergulhos $>30^{\circ}$ para Oeste (Figura 46), representadas principalmente pelos Grupos 2 e 8 (Figura 47).

O Grupo 1, verificado no PP-01 e PP-02, é pouco expressivo no P5, com somente algumas feições classificadas como "Possíveis Fraturas", não sendo assim considerado. $\mathrm{O}$ Grupo 2 é representado por feições paralelas às medidas de foliação com ângulos de mergulho $>60^{\circ}$ e apresentam no P5 direção N0-15W, 
diferentemente das sondagens PP-01 e PP-02, com direções variando de $\mathrm{N}$ a NE. Esse grupo não é observado no estereograma com contornos de densidade corrigidos, uma vez que as fraturas apresentam elevado ângulo de mergulho. No entanto, é importante lembrar que as fraturas deste grupo podem estar subestimadas, visto que são quase paralelas ao eixo de perfuração dificultando sua observação.

O Grupo 7, de direção E-W e mergulho médios entre $35^{\circ}$ e $60^{\circ}$ também é observado neste ponto, porém com menor quantidade de feições quando comparado com os demais grupos. A aplicação da correção de Terzaghi apresenta pouca influência na densidade dessas fraturas.

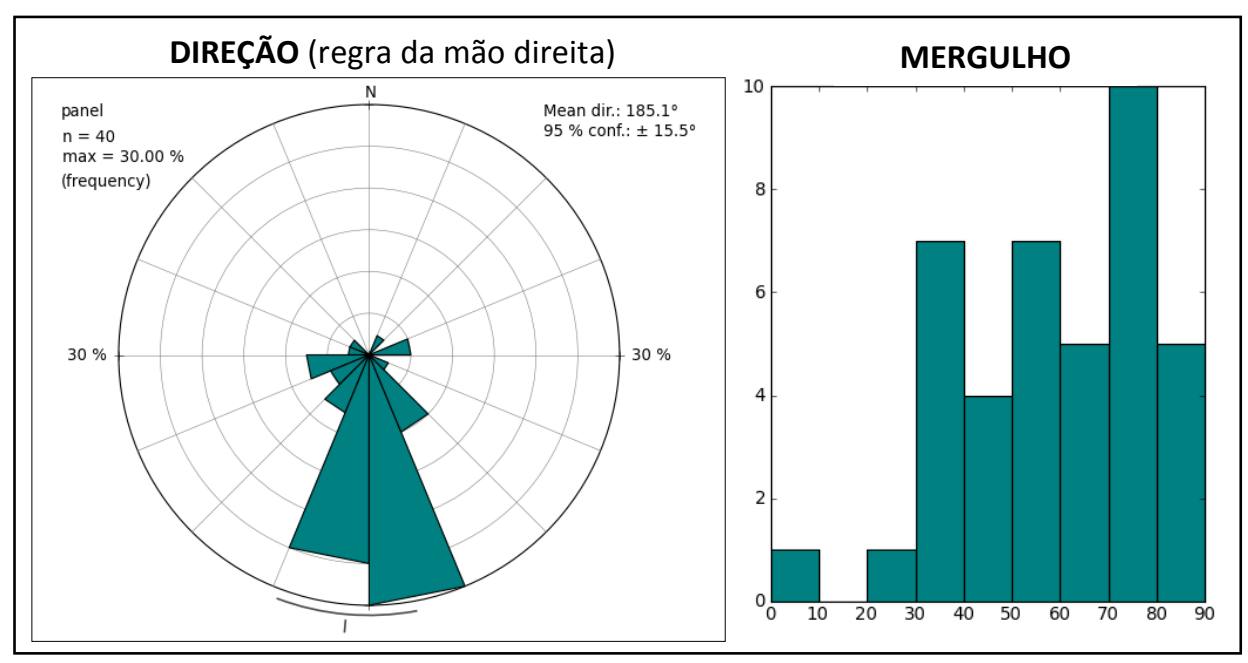

Figura 46 - Diagrama de roseta mostrando as principais direções e histograma dos ângulos de mergulhos dos planos de fraturamento no ponto P5

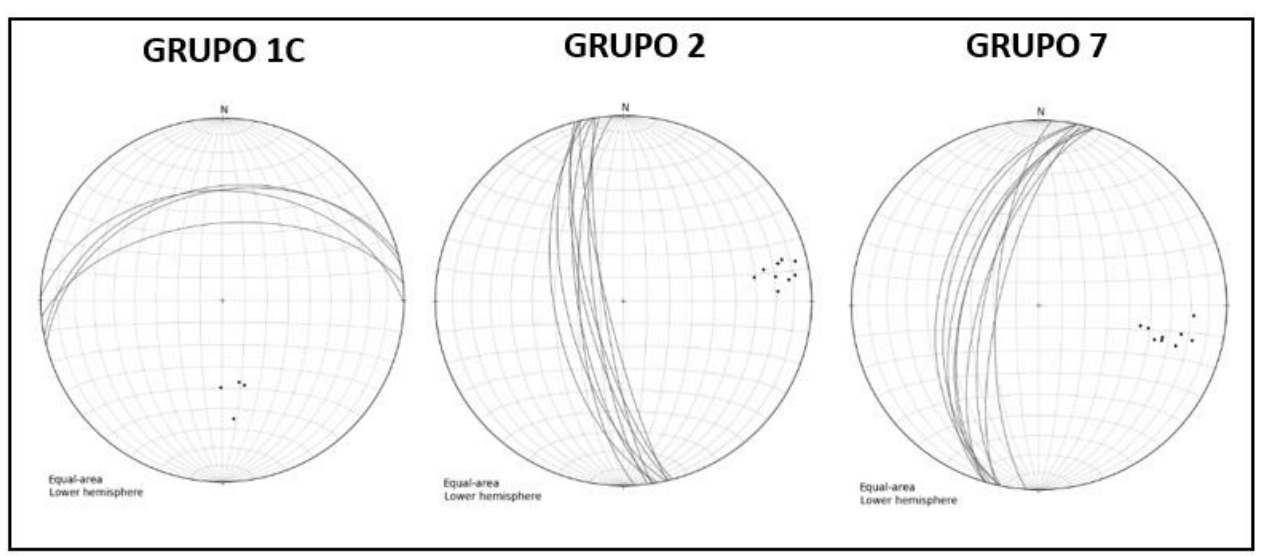

Figura 47 - Círculos Máximos dos principais Grupos de Fraturas identificados no poço tubular P5

Ainda um novo grupo, identificado como Grupo 8, de direção NNE-SSW com 
ângulos de mergulho médios (entre $45^{\circ}$ e $75^{\circ}$ ) para Oeste, aparece neste ponto. Esse Grupo é o mais abundante, sendo mais expressivo ainda após a correção de sua densidade.

Tabela 10 - Quantidade de fraturas corrigidas pela aplicação do método de Terzaghi (1965) para cada grupo de fraturas identificado no ponto P5.

\begin{tabular}{|c|c|c|c|c|c|c|}
\hline Ponto & Grupo & $\begin{array}{c}\text { Mergulho } \\
\text { médio das } \\
\text { Fraturas }\end{array}$ & $\begin{array}{c}\text { Direção } \\
\text { principal }\end{array}$ & $\begin{array}{c}\text { Quantidade } \\
\text { de Fraturas }\end{array}$ & $\begin{array}{c}\text { Fraturas } \\
\text { com a>20 }\end{array}$ & $\begin{array}{c}\text { Quant. Fraturas } \\
\text { - Correção } \\
\text { Terzaghi }\end{array}$ \\
\hline \multirow{3}{*}{ P-05 } & GRUPO 2 & 71,72 & N-S & 6 & 2 & 4,37 \\
\cline { 2 - 7 } & GRUPO 7 & 43,16 & E-W & 4 & 4 & 5,62 \\
\cline { 2 - 7 } & GRUPO 8 & 59,88 & NNE-SSW & 9 & 7 & 13,22 \\
\hline
\end{tabular}

Para o poço tubular P5, não foram elaborados estereogramas para diferentes profundidades, visto que não foi possível confirmar porções mesossomáticas, mais alteradas, se alternam ao longo do perfil com porções leucossomáticas. Ainda assim, é possível verificar que a rocha fresca com poucas feições de fraturas predomina a partir dos $74 \mathrm{~m}$, conforme observado pela perfilagem acústica.

Fraturas dos Grupos 7 são observadas na porção superior da rocha, até $52 \mathrm{~m} \mathrm{e}$ fraturas do Grupo 8 até aproximadamente $64 \mathrm{~m}$ de profundidade. Já as feições paralelas à foliação (Grupo 2) são observadas mais espaçadas ao longo do perfil, entre 55 e $72 \mathrm{~m}$ de profundidade. O espaçamento médio de cada grupo é apresentado na tabela 11 .

Neste ponto, o Grupo 8 apresenta a maior densidade e menor espaçamento, considerando sua presença até a profundidade de $64 \mathrm{~m}$.

Tabela 11 - Tipo de espaçamento, distribuição de densidade e espaçamento médio das fraturas no P5 após a aplicação da correção de Terzaghi.

\begin{tabular}{|c|c|c|c|c|c|}
\hline Grupo & $\begin{array}{c}\text { Total } \\
\text { fraturas }\end{array}$ & $\begin{array}{c}\text { Tipo de } \\
\text { Espaçamento }\end{array}$ & $\begin{array}{c}\text { Intervalo de ocorrência } \\
\text { das fraturas }\end{array}$ & $\begin{array}{c}\text { Densidade } \\
\text { média }\end{array}$ & $\begin{array}{c}\text { Espaçamento } \\
\text { médio }(\mathbf{m})\end{array}$ \\
\hline GRUPO 2 & 8,37 & $\begin{array}{c}\text { Regular } \\
\text { concentrado }\end{array}$ & Entre 55,0 e $72,0 \mathrm{~m}$ & 0,49 & 2,03 \\
\hline GRUPO 7 & 5,62 & Aleatório & Entre 45,4 e 52,0 metros & 0,85 & 1,17 \\
\hline GRUPO 8 & 15,22 & Regular & Entre 52,0 e $64,0 \mathrm{~m}$ & 1,27 & 0,79 \\
\hline
\end{tabular}




\subsection{Perfilagem Flowmeter}

A perfilagem Flowmeter foi empregada neste trabalho a fim de se identificar as entradas e saídas de água nas sondagens PP1 e PP2, assim como as fraturas com maiores vazões, auxiliando no posicionamento dos obturadores utilizados para a etapa de coleta de amostras discretas de trechos do aquífero fraturado. Foram coletados dados dentro do furo diretamente da rocha e também no intervalo revestido, a fim de se determinar a possibilidade de haver alguma contribuição do aquífero freático, mesmo com 0 isolamento desta unidade através do selo confeccionado.

Os resultados apresentados na figura 48 revelaram ausência de fluxo na região dos revestimentos nos dois pontos (PP-01 e PP-02), confirmando a ausência de infiltração de água do aquífero freático pelas emendas do revestimento. 

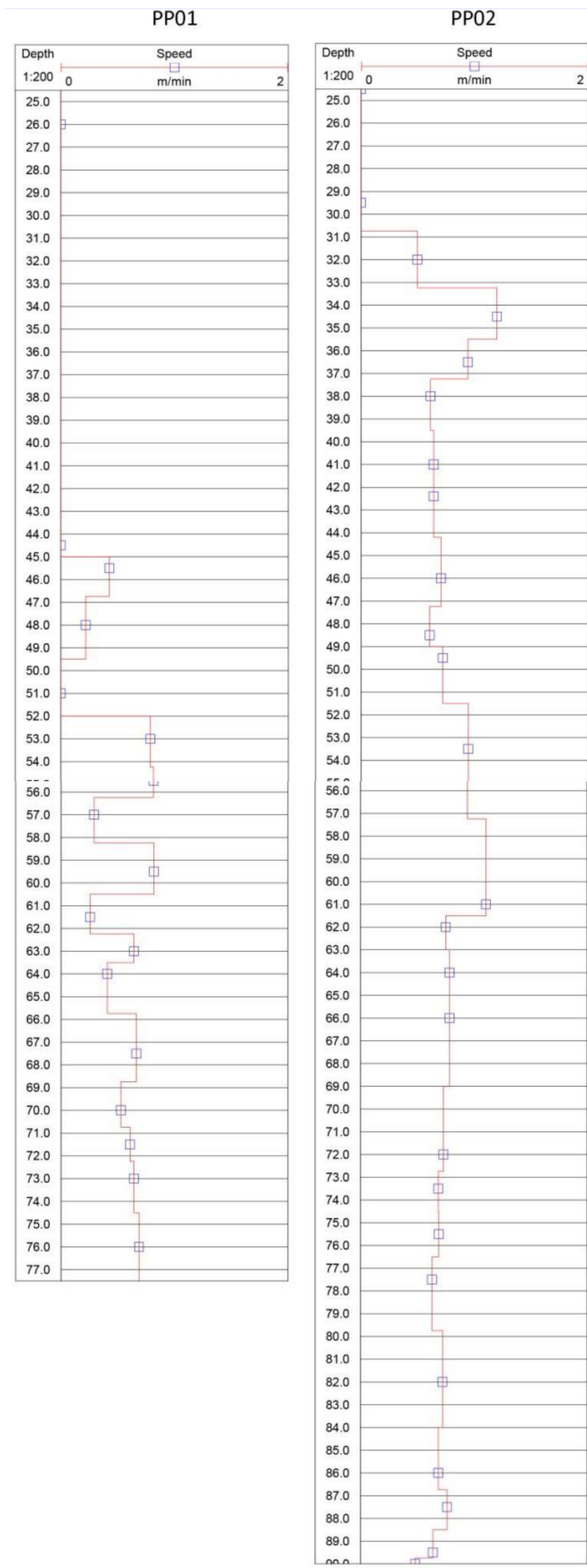

89.0

Figura 48 - Perfil de variação de velocidade média de fluxo 
Nos dois pontos investigados, o fluxo natural de água dentro dos poços se mostrou ascendente. Deste modo, para avaliar se houve entrada ou saída de água entre duas medições, interpretou-se o perfil de vazão dos poços de baixo para cima, de acordo com o sentido natural do fluxo de água dentro do poço.

No ponto PP-01 as médias das velocidades de fluxo variaram de $0 \mathrm{~m} / \mathrm{min}$ (em 51,0 metros de profundidade) a 0,819 m/min (em 59,5 metros). Já no ponto PP-02 a variação na velocidade foi de $0,482 \mathrm{~m} / \mathrm{min}$ (em 90,0 metros) a 1,195 m/min (em 34,5 metros). Nota-se que as velocidades obtidas no ponto PP-02 foram maiores quando comparadas ao PP-01. Este fato pode estar relacionado à maior capacidade de transmitir água nas fraturas interceptadas por este ponto que teve uma vazão média estimada em campo de $8 \mathrm{~m}^{3} / \mathrm{h}$.

Observa-se que no poço PP-01 as principais entradas e saídas de água estão concentradas nos primeiros 20 metros de rocha (dos 45 até os 65 metros), onde predominam as fraturas do Grupo 1, de baixo ângulo, que possuem direção preferencial N-S variando para NNW e NNE.

As maiores velocidades observadas foram de $0,815 \mathrm{~m} / \mathrm{min}$ em $55,5 \mathrm{~m}$ de profundidade e de 0,819 m/min em 59,5 m. Entre 53,0 e 51,0 m existe uma perda expressiva de velocidade de água, chegando à $0 \mathrm{~m} / \mathrm{min}$ na profundidade de $51,0 \mathrm{~m}$. Essa variação pode ser atribuída à saída de água do furo pelas fraturas identificadas a 52,0 $\mathrm{m}$ de profundidade, que podem estar drenando a água. A partir de 64,0 m de profundidade, a média de velocidade observada é de 0,626 $\mathrm{m} / \mathrm{min}$, apresentando poucas variações.

A análise em conjunta dos dados obtidos das perfilagens cáliper, acústica e flowmeter, revelou ainda que, em geral, as fraturas presentes no ponto PP-01 são possivelmente abertas e permitem o fluxo de água subterrânea, com exceção das estruturas presentes em maiores profundidades.

No PP-02 as fraturas mais condutoras estão espaçadas no perfil, porém, as maiores velocidades de fluxo são também observadas na porção mesossomática da rocha.

O trecho que apresenta as maiores variações de velocidade de fluxo corresponde ao intervalo entre 32 e $38,05 \mathrm{~m}$ de profundidade, onde existe $\mathrm{o}$ predomínio de fraturas do Grupo 1 ou fraturas de baixos à médios ângulos de mergulho $\left(<60^{\circ}\right)$. A velocidade medida em $32,0 \mathrm{~m}$ foi de $0,496 \mathrm{~m} / \mathrm{min}$ e em $34,5 \mathrm{~m}$ foi de $1,195 \mathrm{~m} / \mathrm{min}$. Na profundidade de $61,0 \mathrm{~m}$ a $62,0 \mathrm{~m}$ foi verificado outra importante 
variação de velocidade $(1,018 \mathrm{~m} / \mathrm{min}$ a $0,753 \mathrm{~m} / \mathrm{min})$, indicando uma zona importante de fluxo de água. Nesta região, predominam fraturas dos Grupos 3 e 4.

A Tabela 12 apresenta um resumo dos principais intervalos de variação de velocidades de água e dos grupos de fraturas identificados.

Tabela 12: Principais variações de vazão nos pontos PP-01 e PP-02 segundo dados do Flowmeter.

\begin{tabular}{|c|c|c|c|}
\hline Ponto & $\begin{array}{l}\text { Profundidades da } \\
\text { medição com o } \\
\text { Flowmeter }\end{array}$ & $\begin{array}{c}\text { Variação das } \\
\text { Velocidades média } \\
(\mathrm{m} / \mathrm{min})\end{array}$ & Grupo de fraturas predominante \\
\hline \multirow{5}{*}{ PP-01 } & Entre 44,5 e $45,5 \mathrm{~m}$ & De 0 a 0,429 & Não identificado \\
\hline & Entre 51,0 e $53,0 \mathrm{~m}$ & De 0 a 0,786 & Grupo 1 - Direção N a NNE \\
\hline & Entre 55,5 e $57,0 \mathrm{~m}$ & De 0,815 a 0,290 & $\begin{array}{c}\text { Grupo } 3 \text { - Direção E-W } \\
\text { Fraturas NE-SW com mergulho } \\
\text { para NW entre } 40 \text { e } 50^{\circ} .\end{array}$ \\
\hline & Entre 57,0 e $59,5 \mathrm{~m}$ & De 0,290 a 0,819 & $\begin{array}{c}\text { Grupo } 3 \text { - Direção E-W } \\
\text { Grupo } 1 \text { - Direção N-S e NW-SE }\end{array}$ \\
\hline & Entre 59,5 e $61,5 \mathrm{~m}$ & De 0,819 a 0,254 & $\begin{array}{c}\text { Grupo } 1 \text { - Direção N-S } \\
\text { Fraturas NE-SW com mergulho } \\
\text { para NW entre } 45 \text { e } 60^{\circ}\end{array}$ \\
\hline \multirow{5}{*}{ PP-02 } & Entre 30,1 e $32 \mathrm{~m}$ & De 0 a 0,496 & Não identificado \\
\hline & Entre 32 e $34,5 \mathrm{~m}$ & De 0,496 a 1,195 & $\begin{array}{c}\text { Fraturas WNW com mergulho } \\
\text { para NNE entre } 20 \mathrm{e} 30^{\circ}\end{array}$ \\
\hline & Entre 36,5 e $38,0 \mathrm{~m}$ & De 0,939 a 0,610 & $\begin{array}{c}\text { Grupo } 7 \text { - Direção E-W } \\
\text { Grupo } 1 \text { - NE-SW }\end{array}$ \\
\hline & Entre 49,5 e $53,5 \mathrm{~m}$ & De 0,718 a 0,942 & Grupo 1 - Direção NE-SW \\
\hline & Entre 61,0 e $62,0 \mathrm{~m}$ & De 1,018 a 0,753 & Grupo 4 - NE-SW \\
\hline
\end{tabular}

\subsection{Amostragem de Água Subterrânea com Obturadores}

Após a realização da análise estrutural e da avaliação dos intervalos de fraturas mais condutivos, foram selecionados três intervalos em cada uma das sondagens para coleta de amostras de água em intervalos isolados com os obturadores pneumáticos, conforme apresentado na Tabela 13 e no Anexo 1. 
Tabela 13 - Dados das amostras coletadas no aquífero cristalino.

\begin{tabular}{|c|c|c|}
\hline $\begin{array}{c}\text { Ponto } \\
\text { amostrado }\end{array}$ & $\begin{array}{c}\text { Identificação da } \\
\text { amostra }\end{array}$ & Intervalo isolado pelos obturadores (m) \\
\hline $\begin{array}{c}\text { PP-01 } \\
\text { (amostrado em } \\
04 / 09 / 2013)\end{array}$ & PP-01A & Entre 47,15 e 50,85 \\
\cline { 2 - 3 } & PP-01B & Entre 53,05 e 56,75 \\
\hline PP-02 & PP-01C & Entre 57,40 e 61,10 \\
\cline { 2 - 3 }$($ amostrado em & PP-02A & Entre 36,15 e 39,85 \\
\cline { 2 - 3 } $22 / 08 / 2013)$ & PP-02B & Entre 60,60 e 64,30 \\
\hline
\end{tabular}

Para a amostragem dos pontos PP-01 e PP-02, foi realizada a leitura dos níveis de água entre os obturadores e acima dos mesmos, de forma a verificar as variações, avaliar o comportamento hidráulico durante a amostragem, além de averiguar a eficiência do isolamento dos intervalos predefinidos. A amostragem somente foi realizada após a estabilização dos parâmetros físico-químicos medidos.

No ponto PP-01, foi observada uma variação dos níveis d'água entre e acima dos obturadores em todas as profundidades (figuras 49 a 51).

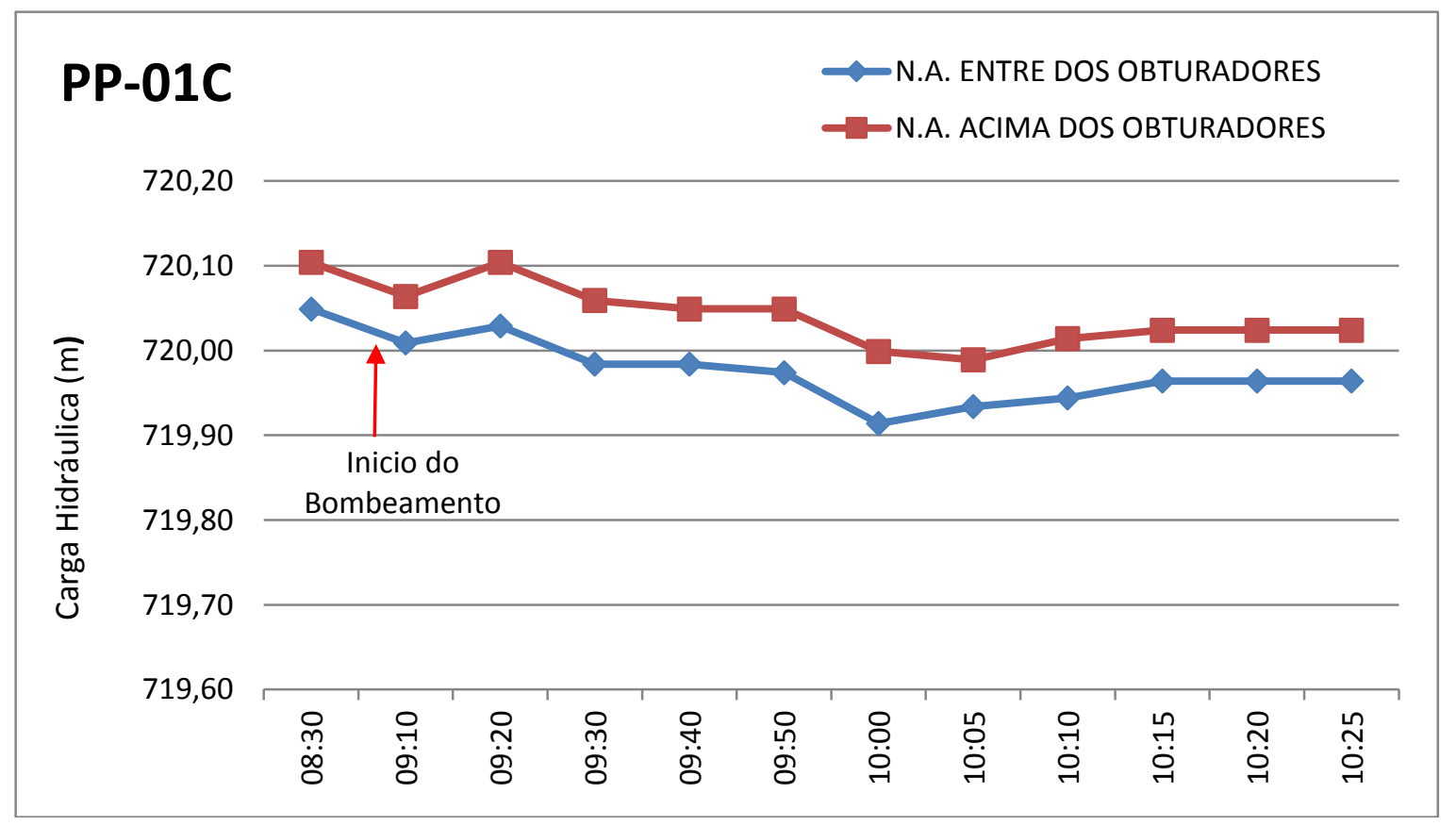

Figura 49 - Variação dos níveis d'água durante a amostragem do ponto PP-01C 


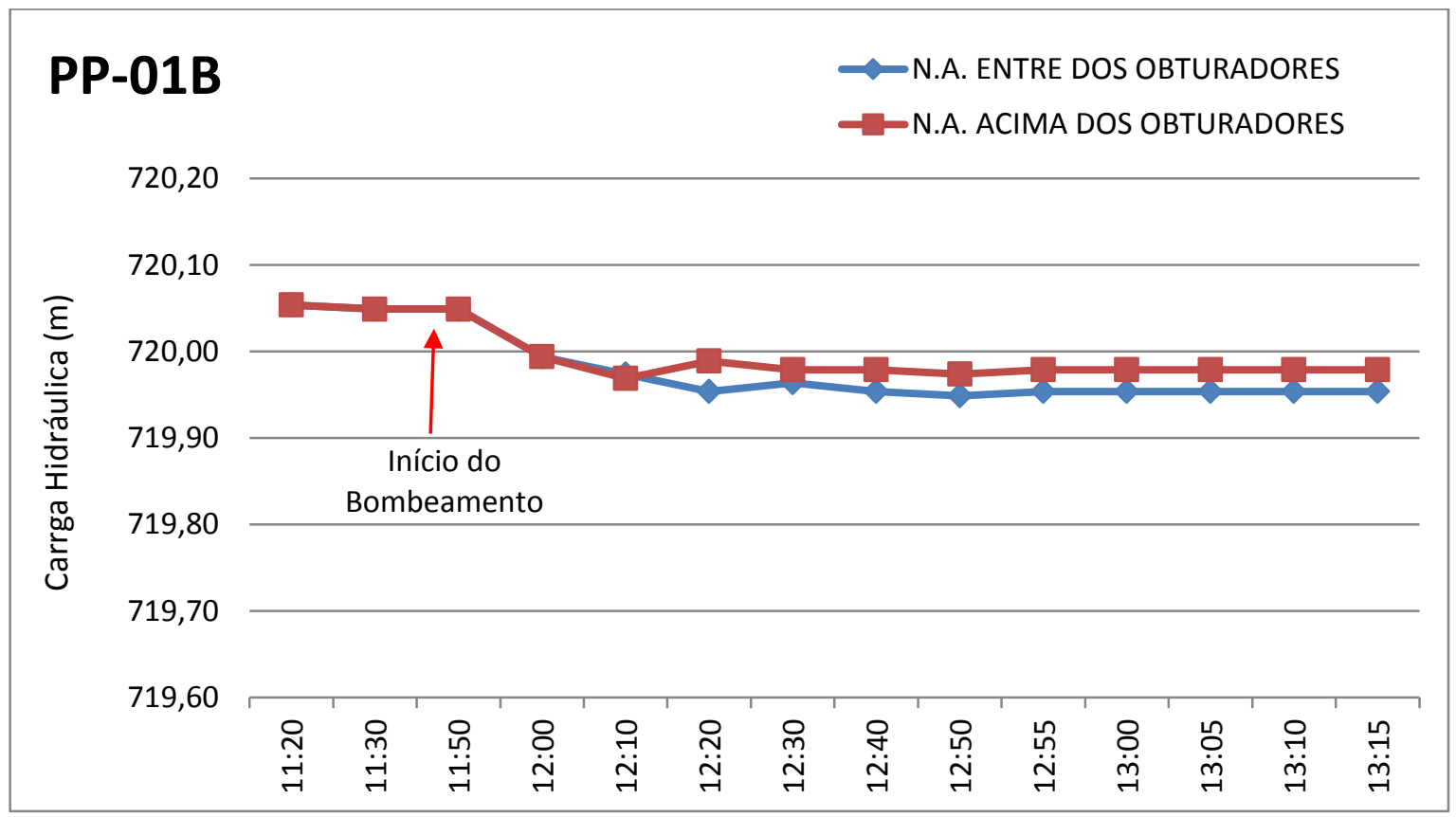

Figura 50 - Variação dos níveis d'água durante a amostragem do ponto PP-01B

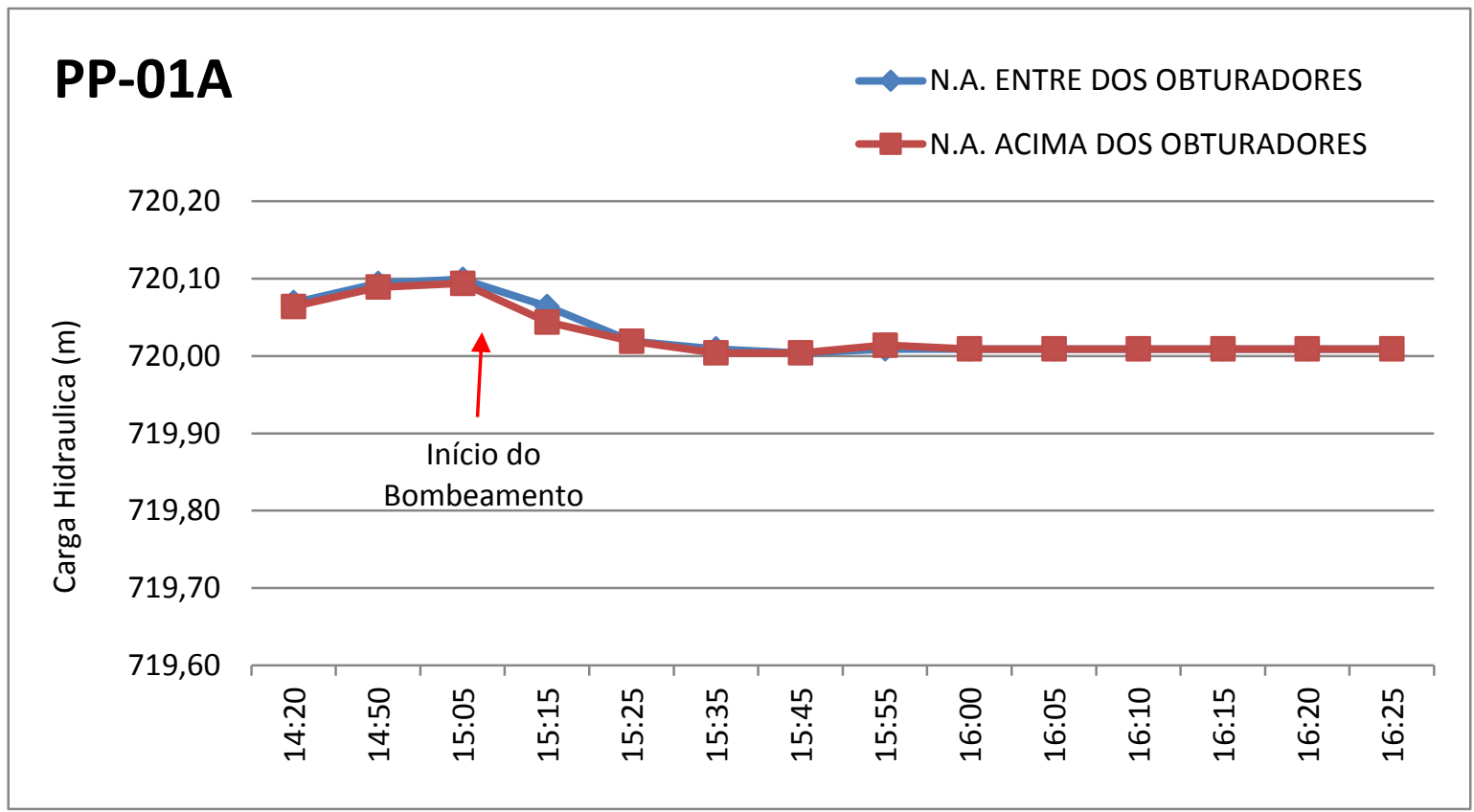

Figura 51 - Variação dos níveis d'água durante a amostragem do ponto PP-01A

A análise dos gráficos permite afirmar que a perturbação de nível de água causada pelo bombeamento entre os obturadores também foi observada no nível de água fora dos obturadores, indicando que não foi possível isolar totalmente os intervalos amostrados, mesmo com o aumento da pressão de enchimento dos obturadores. 
A amostragem foi iniciada pela porção mais profunda, subindo os obturadores para a amostragem das porções mais rasas. O primeiro intervalo amostrado, identificado como PP-01C (Figura 49), compreende o trecho entre 57,40 e 61,10 m onde são verificadas fraturas do Grupo 1, Grupo 2 (de elevado ângulo de mergulho) e Grupo 3 (ângulos médios de mergulhos). Após a descida dos equipamentos de amostragem a carga hidráulica entre os obturadores foi menor que a carga hidráulica medida fora e acima dos obturadores, indicando um potencial vertical de fluxo descendente neste intervalo.

No nível PP-01B (de 53,05 a 56,75 m) é possível observar pouca variação de carga hidráulica entre e acima dos obturadores. Após o início do bombeamento, a carga hidráulica entre os obturadores é um pouco menor que acima dos obturadores, indicando uma componente de fluxo de água ligeiramente descendente. Neste intervalo, as fraturas com ângulos mais elevados são pertencentes aos Grupos 3 e 5 de direção E-W e se intercalam com fraturas de baixo ângulo de direção N-S do Grupo 1 e com fraturas de médio ângulo de mergulho com direção NE-SW.

No nível mais raso PP-01A (de 47,15 a 50,85 m), a variação do nível de água interno é praticamente igual à variação de nível de água externo aos obturadores, não sendo possível avaliar a direção do fluxo entre eles. Neste trecho, são observadas fraturas do Grupo 5 com ângulos de mergulho $>55^{\circ}$. Analisando somente as cargas hidráulicas acima dos obturadores nos 3 intervalos amostrados ao final do tempo de amostragem, é possível também verificar um fluxo levemente descendente.

A variação dos níveis de água medidos entre e acima dos obturados durante a amostragem, pode ser explicada pela má vedação das borrachas dos obturadores, devido à rugosidade da parede do furo, ou ainda pela interconexão entre as fraturas no maciço rochoso, principalmente as de elevado ângulo de mergulho, como mostra o esquema da figura 52. 


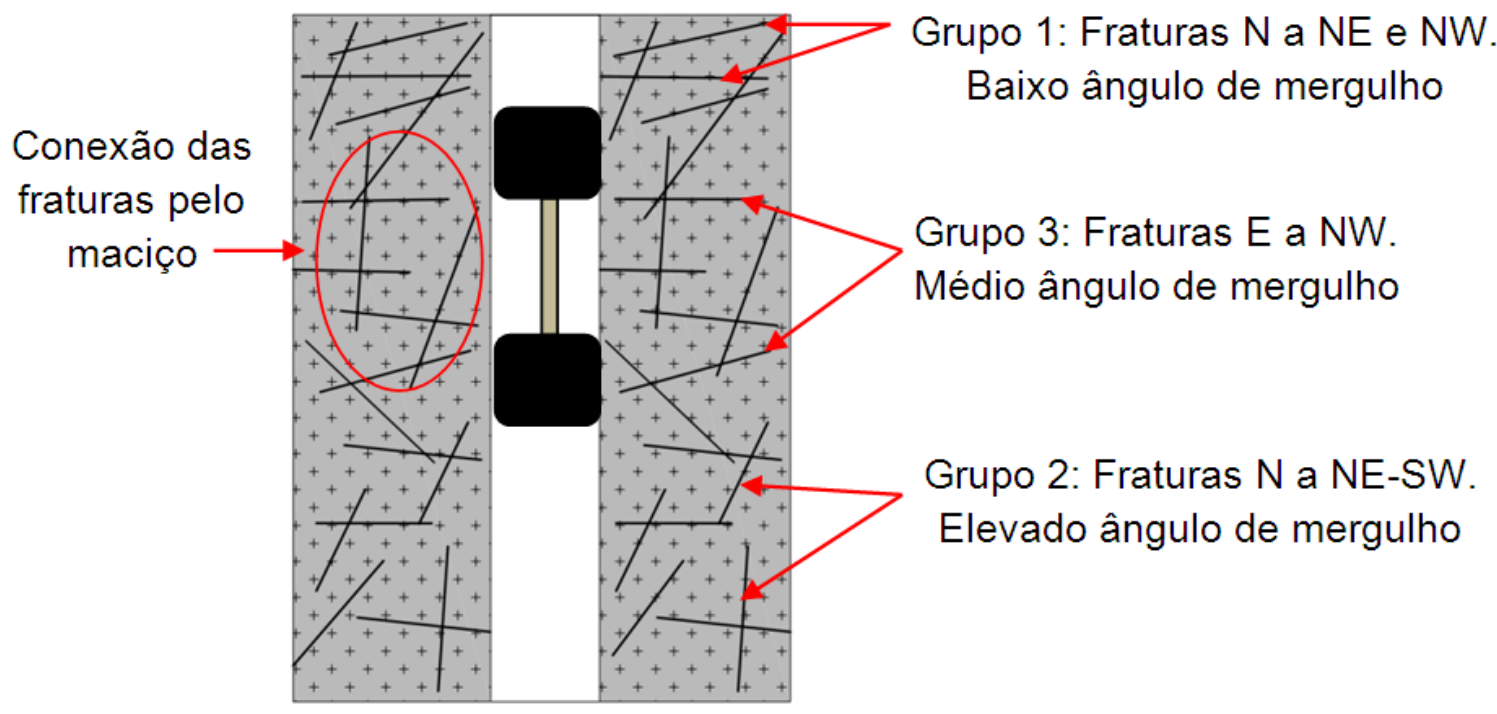

Figura 52 - Esquema da conexão entre os principais grupos de fraturas

Desta forma, devido às propriedades estruturais do gnaisse, os resultados dessas amostras podem corresponder a uma mistura de água dentro do furo, sendo pouco representativas dos intervalos amostrados.

Ressalta-se que a utilização de medidores manuais de níveis de água se mostrou pouco prática e mais suscetíveis a erros, sendo recomendável realizar as medições com um sistema automatizado, utilizando transdutores de pressão com comunicação direta com a superfície e permitindo a visualização das informações em tempo real em campo.

Realizando a mesma avaliação da variação de níveis d'água durante a amostragem do ponto PP-02, verifica-se que o N.A. medido acima do obturador não se altera durante o bombeamento em cada uma das profundidades, enquanto que, no trecho compreendido entre os obturadores, é possível observar uma sutil variação (figuras 53 a 55) indicando uma maior eficiência no isolamento do trecho amostrado. 


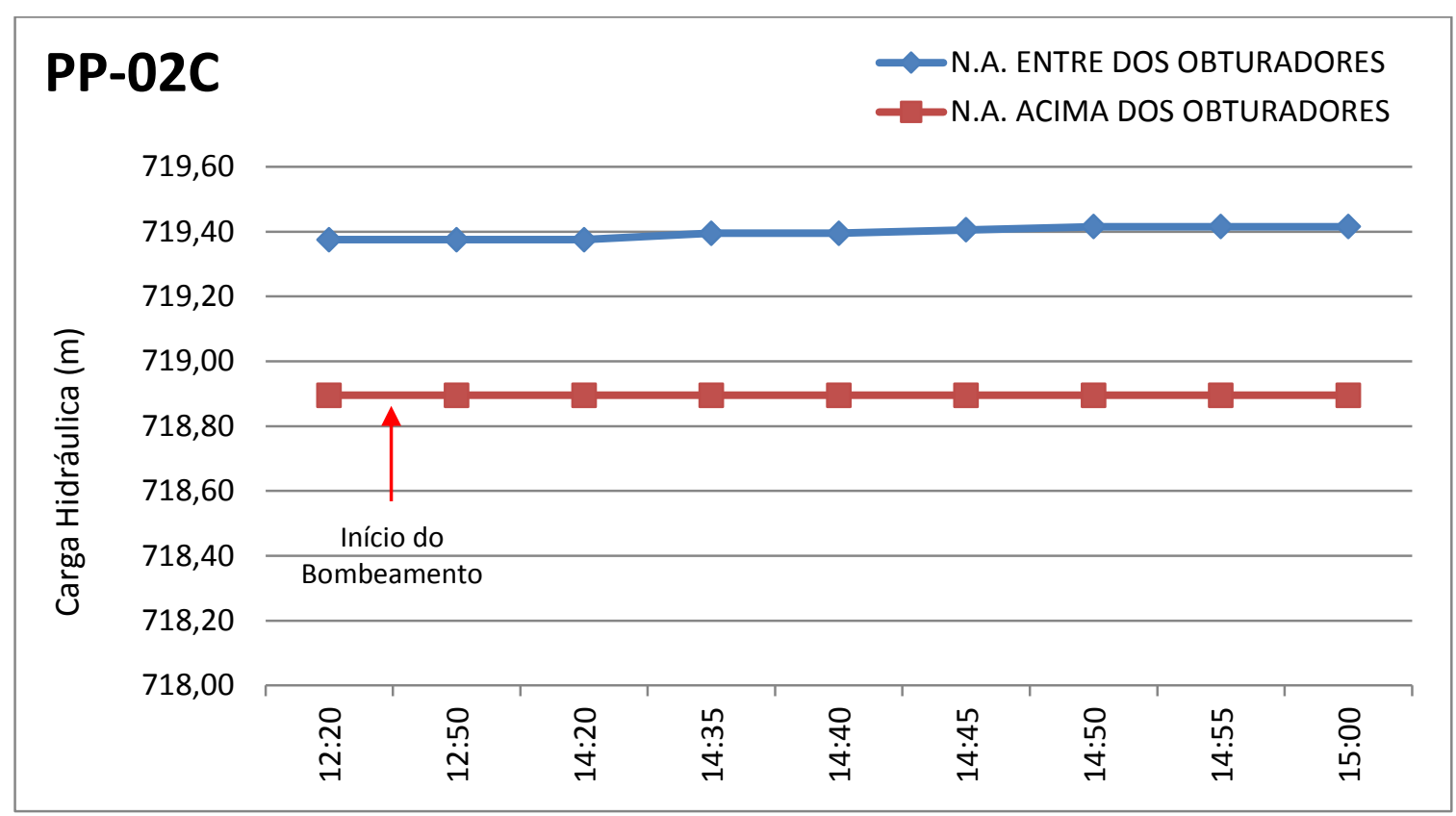

Figura 53 - Variação dos níveis d'água na amostragem do ponto PP-02C

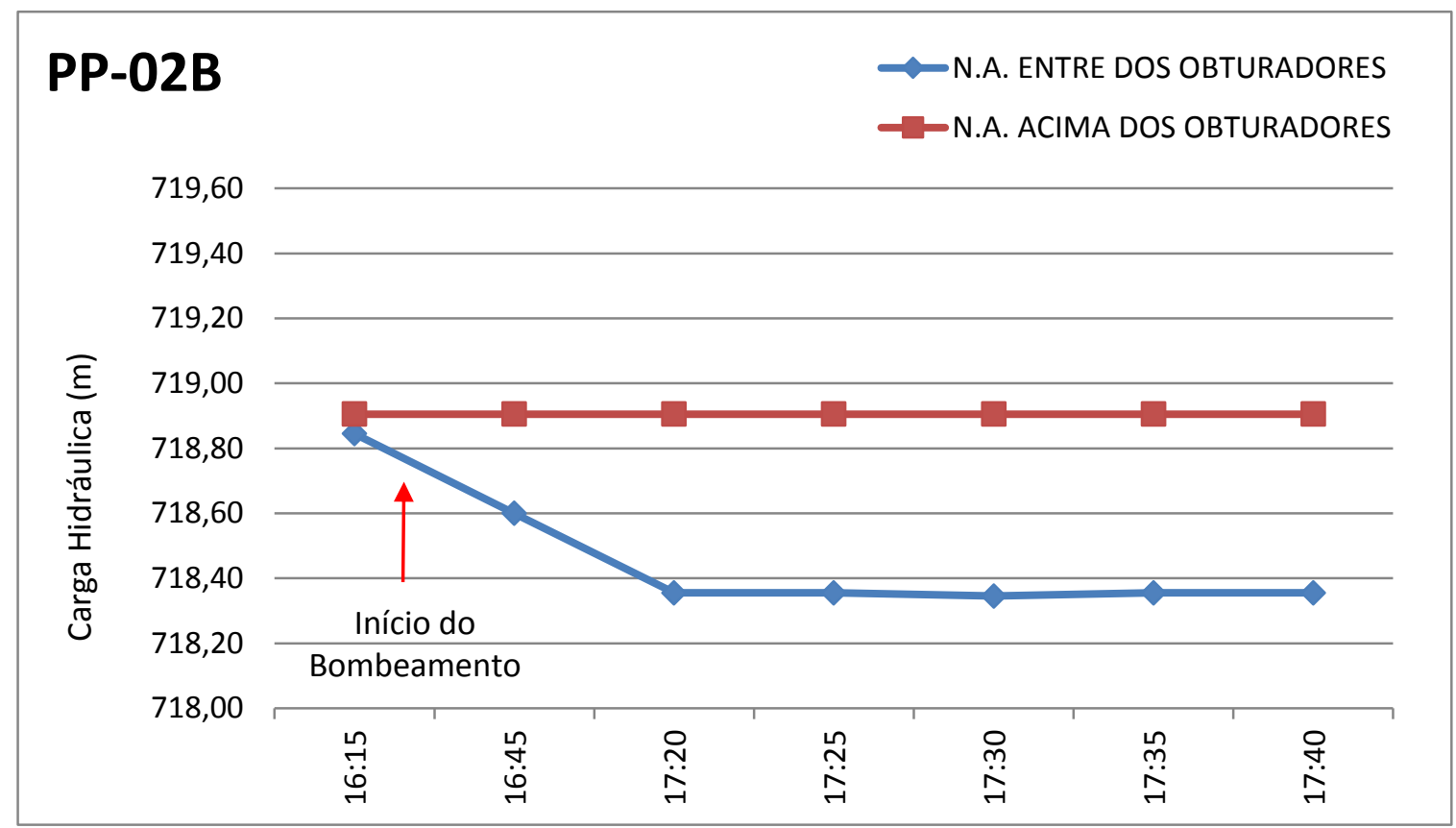

Figura 54 - Variação dos níveis d'água na amostragem do ponto PP-02B 


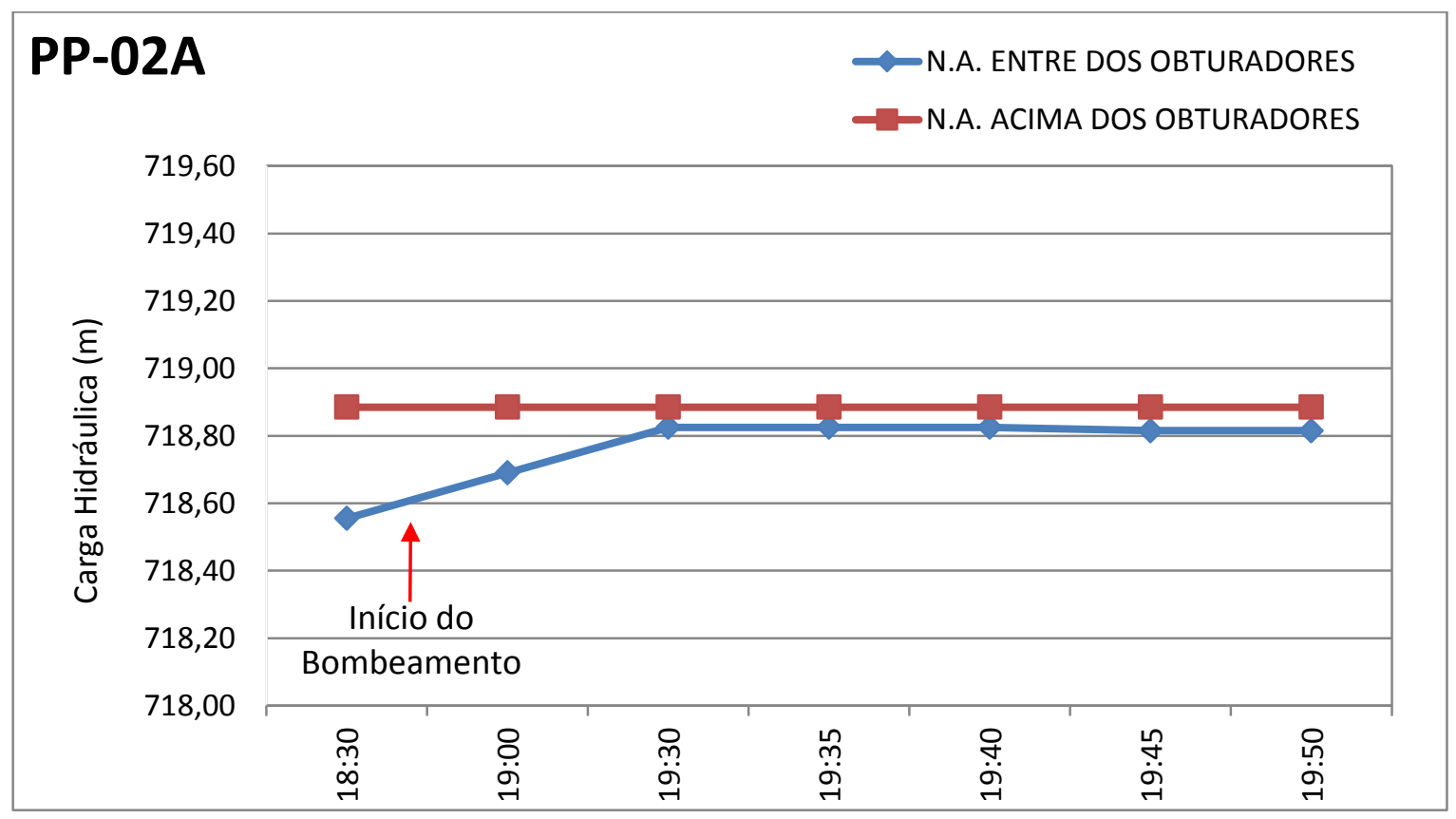

Figura 55 - Variação dos níveis d'água na amostragem do ponto PP-02A

O nível mais profundo amostrado (figura 53) compreende o intervalo entre 84,50 e 88,20 m de profundidade onde predominam fraturas com direção NNE a NESW de baixo a médio ângulo do Grupo 1 intercaladas com fraturas de elevado ângulo de mergulho do Grupo 2. Neste intervalo, após a estabilização, a carga hidráulica entre os obturadores foi maior que a carga hidráulica acima, indicando um fluxo local ascendente.

No segundo nível de água amostrado (PP-02B), de 64,3 a 60,60m, são observadas fraturas do Grupo 3 intercaladas com fraturas do Grupo 4, com ângulos de mergulho entre 55 e $80^{\circ}$. Segundo dados do Flowmeter, este trecho apresenta uma variação importante de velocidade de fluxo da água.

Antes do início do bombeamento, foi possível observar pouca diferença nas cargas hidráulicas entre e acima dos obturadores. Após o início do bombeamento a carga hidráulica entre os obturadores sofre um rebaixamento, que se mantém durante toda a medição e amostragem, ao passo que o nível de água fora dos obturadores não se altera. Analisando o gráfico, pode-se inferir que o trecho isolado possui um fluxo de água descendente em relação à porção acima dos obturadores.

O nível mais raso amostrado compreende o intervalo de 36,15 a 39,85 m onde predominam fraturas do Grupo 1 de baixo a médio ângulos de mergulho $\left(<60^{\circ}\right)$. Neste intervalo, os níveis de água dentro e fora dos obturadores após o início do 
bombeamento apresentam pouca diferença e o fluxo de água se apresenta ligeiramente descendente.

Diferente do PP-01, o PP-02 apresenta trechos menos intemperizados, facilitando a aderência do obturador. Durante a perfuração, foram ainda identificadas fraturas com boa produção de água e a baixa vazão da bomba de amostragem pode não ter interferido significativamente na dinâmica do poço. As diferenças de níveis de água observadas antes e depois do início do bombeamento podem ser devido ao tempo necessário para a estabilização dos níveis de água após a colocação dos obturadores e não devido à influência do bombeamento pela baixa vazão.

De qualquer modo, tendo em vista que as variações de níveis de água foram verificadas somente no intervalo entre os obturadores, pode-se considerar que o isolamento neste ponto foi mais eficiente e a amostragem mais representativa. Caso sejam realizadas novas amostragem em trabalhos futuros, é recomendável a utilização de obturadores com maior comprimento, possibilitando a vedação de um intervalo maior de fraturas, principalmente as de elevado ângulo de mergulho.

Outra limitação observada durante a amostragem foi o fato da distância entre os obturadores ser fixa (neste caso 3,70 m entre eles), interceptando uma quantidade maior de fraturas e dificultando 0 isolamento de grupos de fraturas específicos. O aprimoramento da técnica com a utilização de obturadores ajustáveis ao intervalo necessário é importante, principalmente no caso de rochas bastante fraturadas.

\subsubsection{Parâmetros Físico-químicos}

Os resultados dos dados físico-químicos medidos antes da amostragem de água com os obturadores são apresentados na Tabela 14.

Tabela 14 - Dados Físico-químicos medidos em campo dentro dos obturadores.

\begin{tabular}{|c|c|c|c|c|c|c|}
\hline Poço & $\begin{array}{c}\text { Nível d'água } \\
(\mathbf{m})\end{array}$ & $\mathbf{p H}$ & $\mathbf{T}\left({ }^{\circ} \mathbf{C}\right)$ & $\begin{array}{c}\text { Condutividade } \\
(\mathbf{u S} / \mathbf{c m})\end{array}$ & OD (ppm) & Eh (mV) \\
\hline PP-01A & 21,34 & 5,93 & 24,2 & 370 & 0,93 & 46,30 \\
\hline PP-01B & 21,35 & 6,00 & 24,1 & 370 & 0,77 & 43,00 \\
\hline PP-01C & 21,35 & 5,98 & 24,1 & 370 & 0,64 & 35,90 \\
\hline PP-02A & 22,80 & 6,72 & 24,0 & 181 & 2,48 & 112,30 \\
\hline PP-02B & 22,51 & 6,84 & 24,3 & 180 & 3,01 & 94,50 \\
\hline PP-02C & 21,98 & 7,44 & 27,0 & 222 & 3,10 & 83,50 \\
\hline
\end{tabular}

OD: Oxigênio Dissolvido 
No PP-01, os intervalos amostrados se concentram nos primeiros 20 metros de rocha e as medições de campo realizadas apresentaram valores bem próximos, indicando ambiente de características levemente ácidas, baixos teores de OD e meio oxidante.

No PP-02, os intervalos amostrados estão mais distribuídos ao longo do perfil, sendo possível observar um ligeiro aumento da temperatura, $\mathrm{pH}$ e OD com o aumento da profundidade. Os valores mais elevados de OD no PP-02 podem estar relacionados com o maior fluxo de água nas fraturas, propiciando uma maior aeração.

Os baixos valores de condutividade elétrica observados em ambos os pontos indicam baixas concentrações de sais dissolvidos na água amostrada e baixa reatividade dos minerais presentes na rocha com a água que os percola.

\subsubsection{Resultados das Análises Químicas}

A análise química para a quantificação de compostos orgânicos voláteis mostra concentrações superiores aos valores de potabilidade estabelecido pela Portaria 2914/1 e aos Valores de Intervenção (VI) da CETESB (2014) na área para os compostos 1,1 dicloroeteno, 1,2-dicloroeteno, e tricloroeteno somente no PP-01.

Os compostos diclorometano, tetracloroeteno, tolueno e trans-1,2 dicloroeteno também foram detectados, porém abaixo dos respectivos valores orientadores, e o 1,1-dicloroetano foi detectado acima do Valor Orientador da CETESB porém não possui valor definido para potabilidade. Os resultados obtidos nas amostras de água são descritos na Tabela 15.

Tabela 15 - Concentrações de Compostos Orgânicos Voláteis (VOC's) na água subterrânea nos intervalos amostrados com obturadores nos pontos PP-01 e PP-02.

\begin{tabular}{|l|c|c|c|c|c|c|c|c|}
\hline & & & & & & \\
\hline
\end{tabular}

(1) Somatória dos isômeros ou metabólitos 
Embora no poço PP-02 as concentrações não tenham ultrapassado os valores adotados como referência, também foram observadas concentrações de 1,1dicloroetano, 1,1-dicloroeteno, tolueno e tricloroeteno neste ponto.

Tendo em vista a semelhança entre as concentrações dos compostos detectados e a possibilidade de mistura de águas durante a amostragem com os obturadores, principalmente no PP-01, não é possível confirmar qual das profundidades amostradas apresenta as maiores concentrações dos contaminantes.

Ainda assim, a presença destes contaminantes nas amostras coletadas é mais um indício da conexão do aquífero freático, onde estão presentes as plumas dos principais compostos organoclorados, com o aquífero cristalino profundo. As fraturas observadas nas perfilagens geofísicas, em especial as localizadas nos primeiros metros de rocha, agem como vias de condução da água contaminada em profundidade.

Os resultados da amostragem neste trabalho auxiliam também no entendimento da presença histórica dos compostos organoclorados nos poços de abastecimento localizados distantes das áreas-fonte. A presença destes contaminantes pode estar não só associada com a mistura de águas dos diferentes aquíferos (uma vez que estes poços são antigos e podem apresentar problemas estruturais nos revestimentos posicionados no manto de alteração) como também com a migração dos contaminantes pelas fraturas que se apresentam interconectadas.

\subsection{Instalação de Poços de Monitoramento e Ensaios Hidráulicos}

A instalação dos poços foi realizada após a execução das amostragens e a análise conjunta dos resultados, de acordo com os procedimentos descritos no Item 5.4 .

Os poços foram instalados nos intervalos em que foram verificadas as maiores variações de velocidades medidas pelo Flowmeter e as maiores concentrações de contaminantes verificadas pela amostragem com os obturadores. A figura 56 apresenta o perfil dos poços instalados.

No poço PP-01 o filtro foi instalado na profundidade de 50,8 até $54,8 \mathrm{~m} \mathrm{(4}$ metros de comprimento) em um intervalo bastante fraturado, com predominância de fraturas de baixo ângulo de mergulho. As maiores concentrações dos compostos orgânicos e as maiores variações de fluxo observadas pelo Flowmeter no PP-01 
foram verificadas neste intervalo. O restante do furo (de 78,0 até $54,8 \mathrm{~m}$ ) foi cimentado antes da instalação do poço de monitoramento.

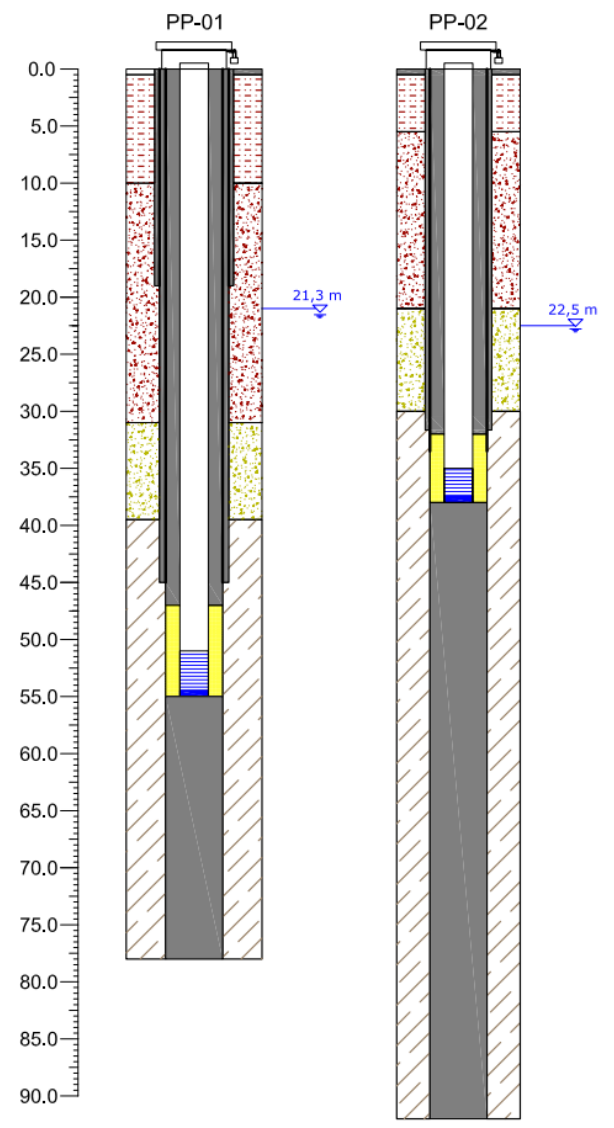

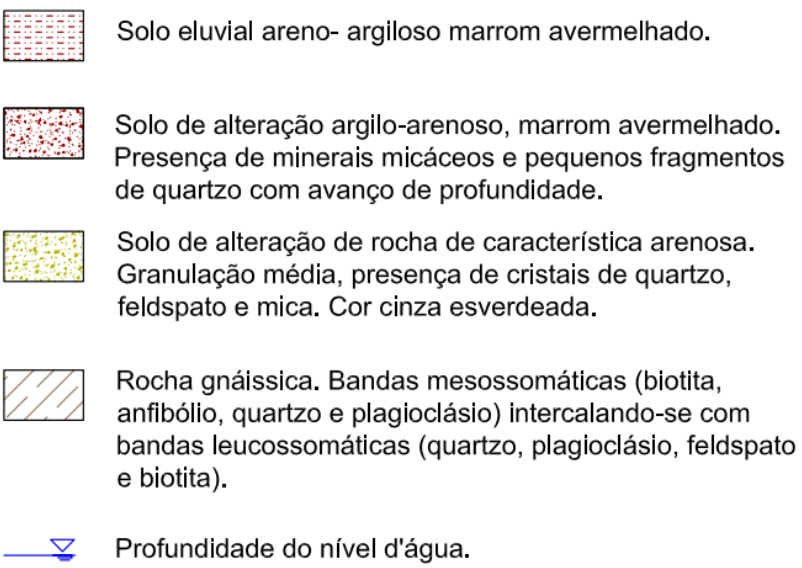

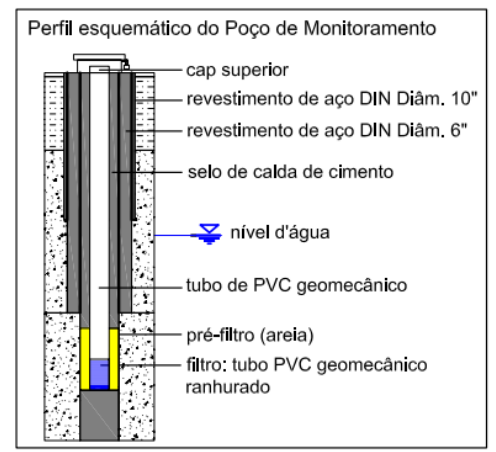

Figura 56 - Perfil litológico e construtivo dos poços instalados

De acordo com os resultados do Flowmeter, o intervalo da seção filtrante apresenta uma saída de água importante, considerando um fluxo de água ascendente. No entanto, de acordo com as medições de níveis de água realizada durante a amostragem com os obturadores, é possível que o fluxo neste local seja descendente, existindo possivelmente uma entrada de água na profundidade de aproximadamente $52,0 \mathrm{~m}$.

No PP-02 o filtro possui 3 metros de comprimento, de $35,35 \mathrm{~m}$ até $38,35 \mathrm{~m}$, e está instalado em um intervalo com predominância de fraturas do Grupo 1, interceptando uma importante zona de fluxo de água, que apresentou as maiores concentrações de compostos orgânicos e as maiores velocidades médias. Este trecho apresenta importantes saídas de água pelas fraturas, considerando um fluxo de água descendente identificado durante as medições de cargas hidráulicas com os obturadores. A cimentação da perfuração foi realizada de 92,0 até 38,35 metros. 
Em ambos os poços o pré-filtro foi colocado até aproximadamente 3 metros acima do filtro, a fim de evitar que a calda de cimento que compõe o selo do poço obstruísse as entradas de água do filtro.

\subsubsection{Ensaios de Permeabilidade}

Após a instalação dos poços de monitoramento, foi realizado o bombeamento dos poços para limpeza e, na sequência, conduzido o teste de recuperação de níveis de água. $\mathrm{O}$ intervalo analisado corresponde à zona permeável do poço onde estão instalados o filtro e o pré-filtro.

Os dados foram tratados utilizando o método de Hvorslev obtendo resultados de condutividade $\mathrm{K}$ de $1,45 \times 10^{-6} \mathrm{~m} / \mathrm{s}$ para o PP-01 e de $5,34 \times 10^{-7} \mathrm{~m} / \mathrm{s}$ para o PP- 02 , indicando uma maior condutividade no PP-01.

\subsubsection{Bombeamento}

Para avaliação da conectividade do aquífero profundo com o aquífero raso da unidade industrial, foi realizado o bombeamento do poço tubular profundo P6, a uma vazão constante de $2,1 \mathrm{~m}^{3} / \mathrm{h}$, sendo observados os níveis de água em três poços rasos e no poço de observação profundo PP-01 instalado na rocha.

Conforme apresentado no item 5.6, o bombeamento teve duração de 11 horas e vinte minutos, com início no dia 5 de setembro às $6: 25$ hs. A figura 57 apresenta o gráfico de variação dos níveis de água medidos em cada um dos poços de observação. 


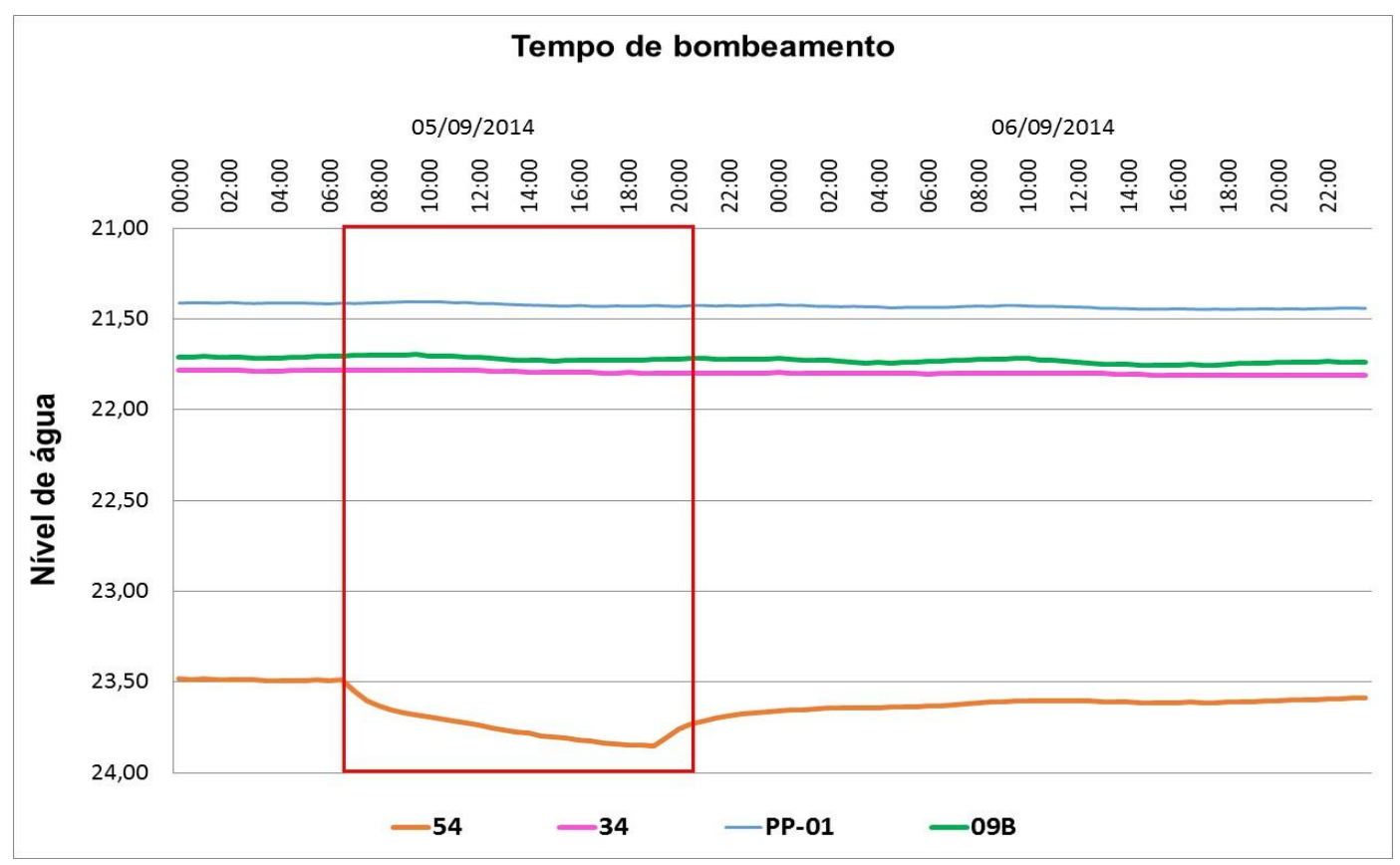

Figura 57 - Gráfico de variação de nível de água dos poços de observação medidos durante o bombeamento do P6

Como pode ser observado, somente o poço 54 apresentou influência do efeito do bombeamento do P6. Durante o ensaio foi observada uma variação de carga hidráulica máxima de 0,367 m neste poço. Nos demais poços rasos e no poço profundo PP-01, não foi observada mudança de nível de água que caracterizasse influência do bombeamento.

O poço 54 é o que se encontra mais próximo do $\mathrm{P} 6$, localizado à aproximadamente $17 \mathrm{~m}$ de distância (figura 32). Possui profundidade de 29,5 m e está instalado no aquífero freático, no solo de alteração.

Apesar do pouco tempo de bombeamento, o ensaio possibilitou confirmar a conexão entre os aquíferos e a rápida influência do bombeamento dos poços tubulares nos poços rasos, indicando que as fraturas existentes na rocha estão hidraulicamente conectadas com o aquífero raso existente na base do manto de alteração. A figura 58 apresenta os perfis dos poços e um esquema da influência do bombeamento. 


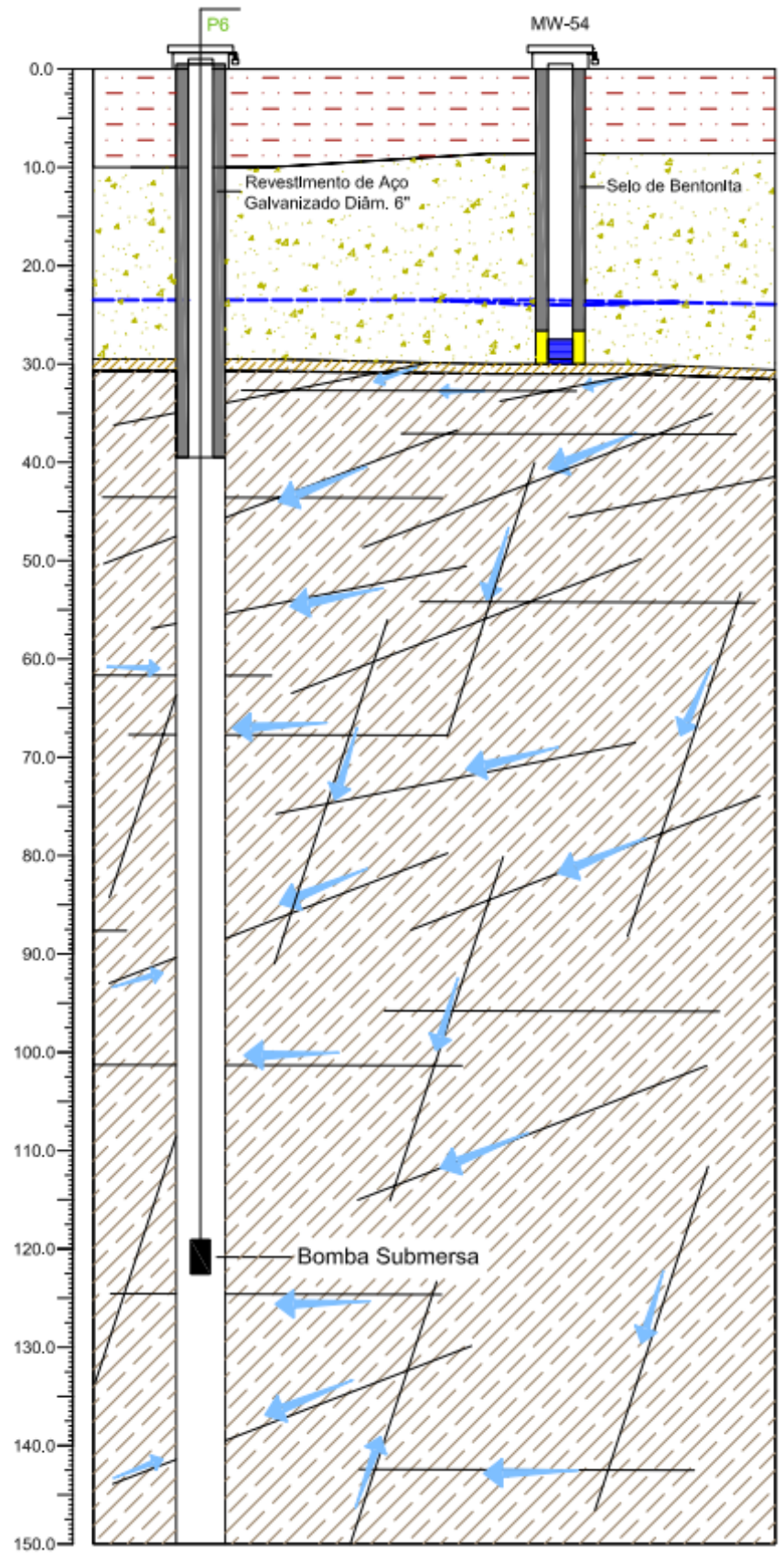

N.A antes do Bombeamento: $23,48 \mathrm{~m}$ N.A. Após o Bomboamento: 23,85 m Rebaixamento de $36 \mathrm{~cm}$

Legenda:

- _._. Solo eluvial silto-argiloso à silto-arenoso marrom avermelhado.

Solo de alteração argilo-arenoso, marrom avermelhado a ocre. Presença de mlnerals mlcáceos e pequenos fragmentos de quartzo com avanço de profundidade.

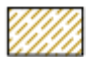

Interface entre manto de alteração e topo rochoso (gnalsse mlgmatítlco)

Rocha gnáissica Cinza escura, pouco alterada, rlca em feldspato e biotita.

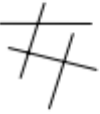

Esquema de conexão das fraturas

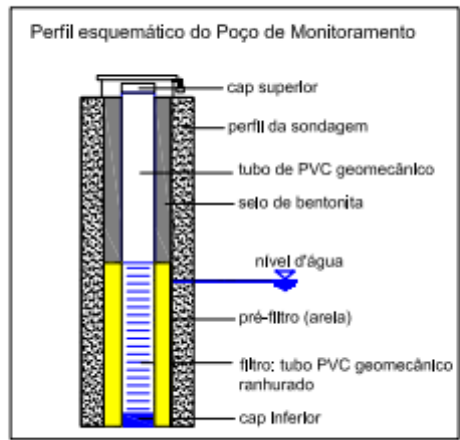

Figura 58 - Esquema da conexão entre os aquíferos em regime de bombeamento

\subsection{Amostragem dos Poços de Monitoramento}

Após a instalação dos poços foram realizadas duas campanhas de amostragem de água para análise de VOC. Os resultados das análises são apresentados na tabela 16. 
Tabela 16 - Concentrações de Compostos Orgânicos Voláteis (VOC's) na água subterrânea dos poços PP-01 e PP-02.

\begin{tabular}{|l|c|c|c|c|c|c|}
\hline \multirow{2}{*}{ Parâmetros $(\boldsymbol{\mu g} / \mathrm{L})$} & \multicolumn{2}{|c|}{ PP-01 } & \multicolumn{2}{c|}{ PP-02 } & $\begin{array}{c}\text { Portaria } \mathbf{n}^{\circ} \\
\mathbf{2 . 9 1 4}\end{array}$ & $\begin{array}{c}\text { CETESB } \\
\mathbf{2 0 1 4}\end{array}$ \\
\cline { 2 - 7 } & nov/13 & abr/14 & nov/13 & abr/14 & & LI \\
\hline Tetracloroeteno & $\mathbf{2 , 4}$ & $<1$ & $\mathbf{1 , 6}$ & $<1$ & 40 & 40 \\
\hline Tricloroeteno & $\mathbf{5 , 7}$ & $\mathbf{1 , 0}$ & $\mathbf{3 , 8}$ & $\mathbf{3 , 8}$ & 20 & 20 \\
\hline Cis-1,2-Dicloroeteno & $\mathbf{6 1}$ & $\mathbf{1 6}$ & $\mathbf{1 , 1}$ & $\mathbf{1 , 2}$ & $50^{(1)}$ & $50^{(1)}$ \\
\hline Trans-1,2-Dicloroeteno & $<1$ & $<1$ & $<1$ & $<1$ & $50^{(1)}$ & $50^{(1)}$ \\
\hline 1,1-Dicloroeteno & $\mathbf{1 0}$ & $\mathbf{1 , 9}$ & $\mathbf{1 2}$ & $\mathbf{1 5}$ & 30 & 30 \\
\hline 1,1-Dicloroetano & $\mathbf{5 5}$ & $\mathbf{1 4}$ & $\mathbf{2 , 2}$ & $\mathbf{3 , 2}$ & - & 53 \\
\hline Diclorometano & $\mathbf{1 , 7}$ & $<1$ & $<1$ & $<1$ & - & 20 \\
\hline Tolueno & $\mathbf{1 , 7}$ & $<1$ & $<1$ & $<1$ & 170 & 700 \\
\hline
\end{tabular}

(1) Somatória dos isômeros ou metabólitos

As análises químicas dos poços já instalados apontam concentrações de organoclorados em ambos os poços, porém, assim como observado na amostragem com os obturadores, apenas o PP-01 apresentou concentrações acima dos valores orientadores na amostragem de novembro de 2013, apresentando uma redução das concentrações na amostragem de abril de 2014.

Comparando os resultados das amostras coletadas nos poços com os resultados dos intervalos amostrados com os obturadores, observa-se que no PP-01 todos os compostos sofrem redução das concentrações. Neste intervalo foi identificada uma importante entrada de água que pode estar contribuindo para o decaimento das concentrações, caso essa água seja proveniente de porções menos contaminadas do aquífero.

No PP-02, com exceção do tolueno, os compostos organoclorados vêm apresentando um leve aumento das concentrações, indicando um fluxo de água contaminada do aquífero nesta região. Neste intervalo onde está instalada a seção filtrante do poço, foi observada uma variação da velocidade de fluxo indicando possíveis saídas de água (considerando o fluxo descendente nesta porção), contribuindo para o transporte do contaminante para outros locais. 


\subsection{Modelo Conceitual de Contaminação}

$\mathrm{Na}$ área de estudo, o manto de alteração é constituído pelo intemperismo da rocha gnáissica, representado por um material silto-argiloso a silto-arenoso, com presença marcante de minerais micáceos e cristais de quartzo em espessuras que alcançam até $40 \mathrm{~m}$ de profundidade. No geral, possui comportamento semelhante ao de um aquífero de porosidade primária, mas com zonas de maior ou menor resistência, possivelmente associadas a estruturas da rocha gnáissica parental, que podem criar caminhos preferenciais de fluxo no aquífero livre.

As perfurações foram locadas na porção mais elevada do terreno e atingiram o topo rochoso em 39,5 m no PP-01 e em $30 \mathrm{~m}$ no PP-02. O aquífero fraturado na área é composto por gnaisses pertencentes à Unidade Migmatítica Intermediária (Campos Neto \& Caby, 2000) e, conforme observado na filmagem da perfuração e nos afloramentos visitados em trabalhos anteriores, é composto por intercalações entre porções mesossomáticas e leucossomáticas da rocha gnáissica. Do topo da rocha até a profundidade média de 65,0 m predomina a porção mesossomática do gnaisse, de coloração cinza escura com presença de minerais como biotita, hornblenda, anfibólio, feldspato alcalino e quartzo. Este intervalo se apresenta bastante fraturado e intemperizado, tendo sido obtidos os maiores valores de radiação gama. A partir de aproximadamente $65,0 \mathrm{~m}$ de profundidade, ocorre o predomínio de porções mais claras, formadas essencialmente por quartzo, feldspato alcalino e plagioclásio.

O modelo conceitual do aquífero fraturado é apresentado na figura 59 e foi desenvolvido com base nos resultados deste trabalho e analisado em conjunto com os estudos prévios realizados na área. Para auxiliar no entendimento do fluxo, foi elaborada ainda a seção hidrogeológica apresentada na figura 60 . 


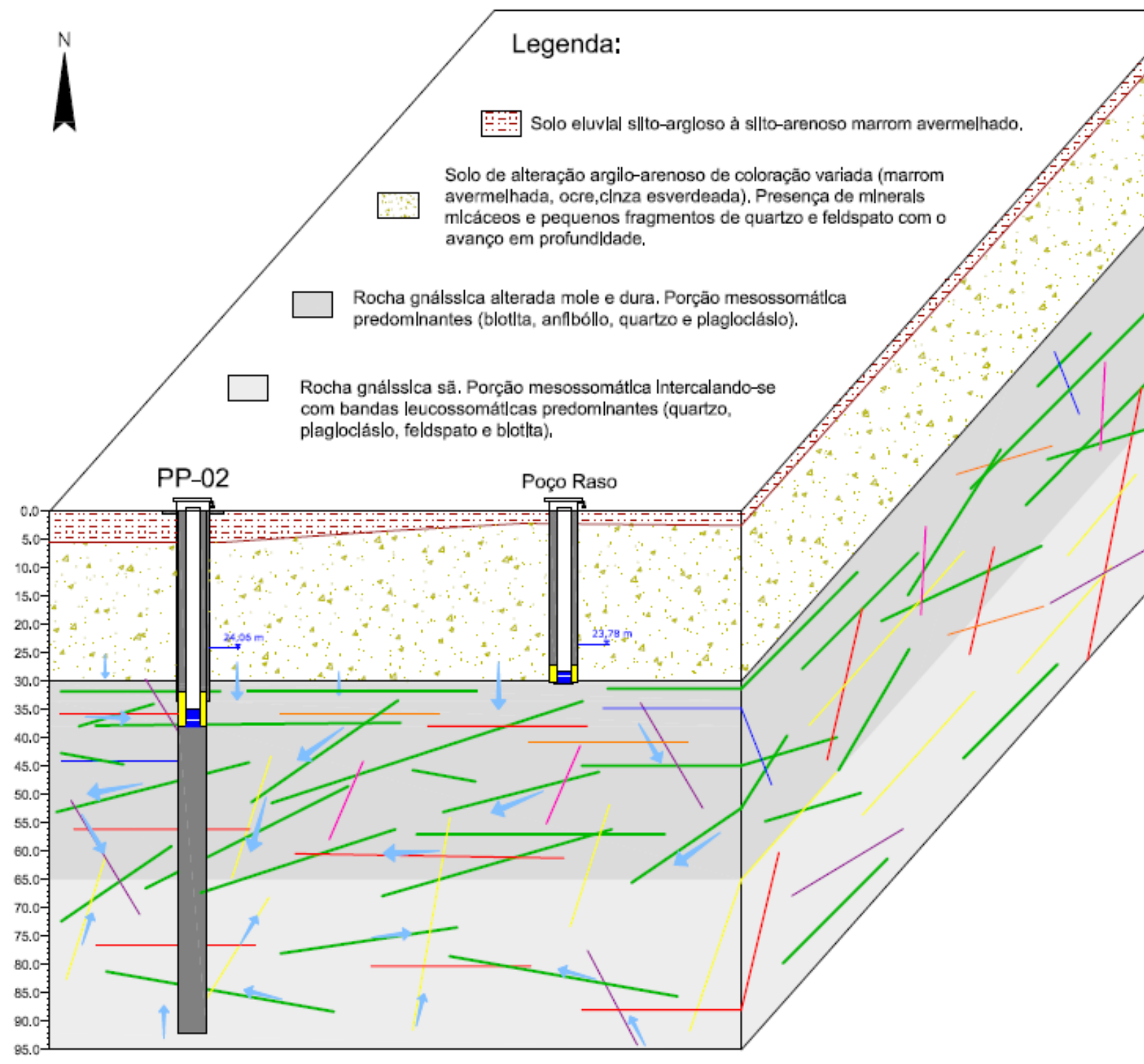

Fraturas com maior importância para o fluxo de água subterrânea:

GRUPO 1 - Verde

- $\quad$ NE-SW com baixo a médio ângulo de mergulho para NW (malorla do Grupo 1)

- $\quad \mathrm{N}-\mathrm{S}$ com ângulo de mergulho $<45^{\circ}$ para W e subord|namente para $\mathrm{E}$

- $\quad$ NW-SE com ângulo balxo de mergulho para SW

GRUPO 5 - Azul

E-W com ângulo elevado de mergulho para $\mathrm{N}$

GRUPO 3 - Vermelho

E-W com ångulo de mergulho $>45^{\circ}$ para S

GRUPO 7 - Laranja

E-W com ângulo de mergulho entre $35^{\circ}$ e $55^{\circ}$ para $\mathrm{N}$

Fraturas com menor Importâncla para

o fluxo de água subterrânea:

GRUPO 4 - Roxo

NE-SW com ângulo de mergulho $>50^{\circ}$ para SE

GRUPO 2 - Amarelo

$\mathrm{N}$ a NE-SW com ângulo de mergulho $>60^{\circ}$ para W e NW,

GRUPO 6 - Rosa

NW-SE com elevado ângulo de mergulho para SW

Figura 59 - Modelo Conceitual da área 


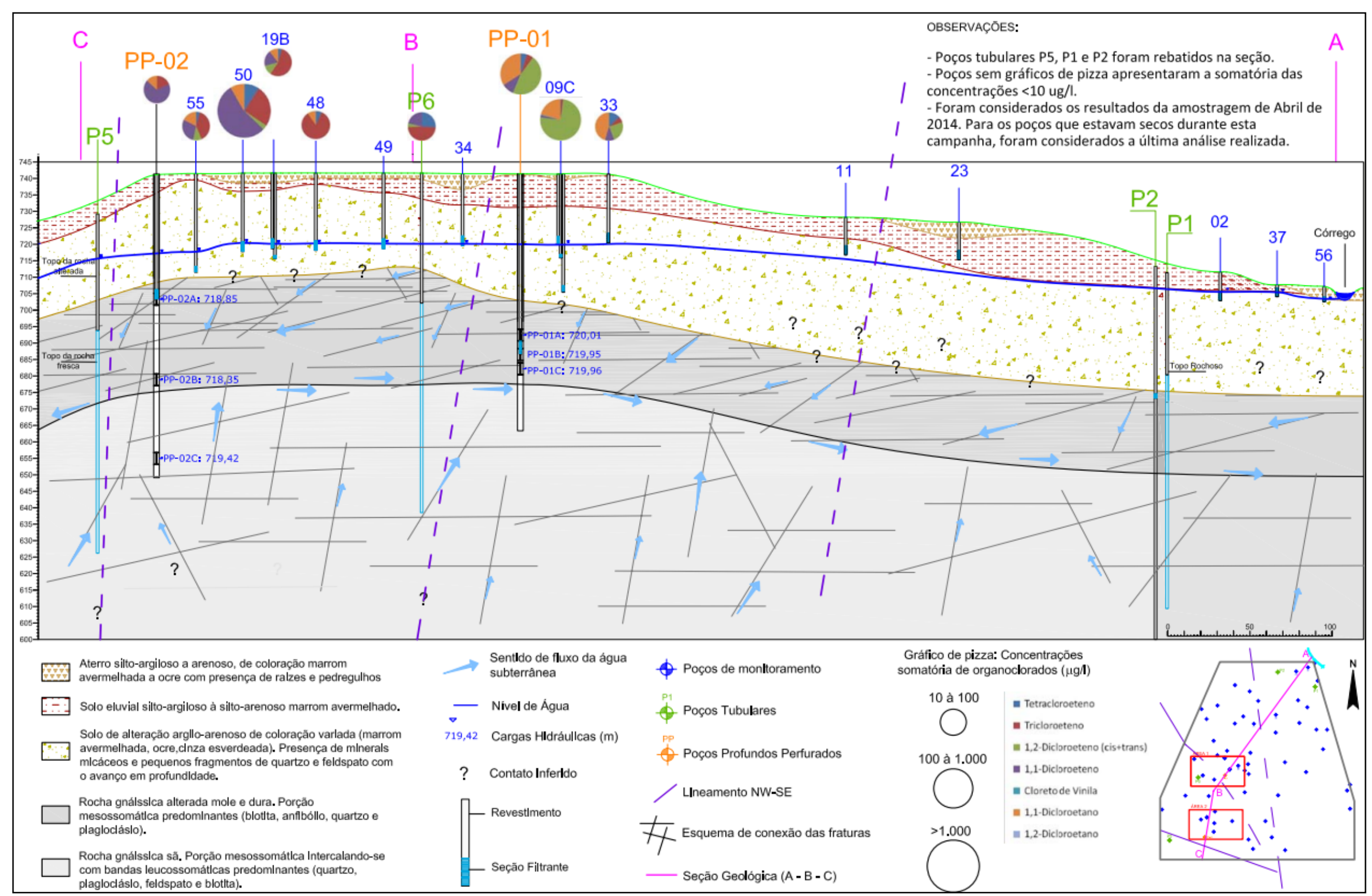

Figura 60 - Seção hidrogeológica da área de estudo e compostos organoclorados identificados. 
O Anexo 1 apresenta uma compilação dos dados das perfilagens realizadas em cada ponto, auxiliando na interpretação e construção do modelo conceitual apresentado.

As fraturas de direção $\mathrm{N}$ a NNE e mergulho para Oeste são as mais frequentes ao longo de todo o perfil do PP-01. Na porção mesossomática superior da rocha são observadas as maiores densidades de fraturas e as maiores velocidades e variações de fluxo de água, com predomínio de fraturas do Grupo 1, que apresentam ângulos de mergulho $<60^{\circ}$. A partir de $64,0 \mathrm{~m}$ de profundidade as fraturas de direção N-S pertencem ao Grupo 2, que possuem ângulo maior de mergulho e são paralelas às medidas de foliação.

Outras fraturas com elevados ângulos de mergulho são verificadas ao longo de todo o perfil. Fraturas do Grupo 5 são concentradas na parte superior da rocha e as fraturas do Grupo 3 ocorrem por todo o trecho perfurado. Esses dois grupos de fraturas de ângulo de mergulho médio a elevado $\left(>45^{\circ}\right)$ possuem direção principal EW perpendicular às fraturas do Grupo 1 de baixo ângulo, sendo possível observar uma intercalação dessas fraturas, o que pode favorecer a conexão entre trechos mais rasos do aquífero fraturado com trechos mais profundos, contribuindo também para a migração de água contaminada em profundidade.

No PP-02, $40 \%$ das fraturas possuem direção NE-SW, pertencentes principalmente aos Grupos 1, 2 e 4. Assim como no PP-01, a maior densidade de fraturas é observada na porção superficial, mais alterada da rocha, que vai até aproximadamente $65,0 \mathrm{~m}$ de profundidade, onde também são verificados os valores mais elevados de velocidade da água medidos pelo Flowmeter.

Fraturas do Grupo 1, de baixo a médio ângulo de mergulho, são observadas ao longo de todo o perfil no PP-02. Na porção superior da rocha até aproximadamente $65,0 \mathrm{~m}$ de profundidade essas fraturas se intercalam com fraturas dos Grupos 3, 4, 6 e 7, que possuem ângulo de mergulho $>40^{\circ}$. A partir de $43,0 \mathrm{~m}$ são também observadas fraturas do Grupo 2, de elevado ângulo de mergulho e paralelas à foliação, sendo estas predominantes em profundidade.

No geral, em ambas as perfurações, as fraturas com maior atividade hidráulica são as de baixo a médio ângulo de mergulho, com direção $\mathrm{N}$ a NNE (principalmente no PP-01) ou NE-SW pertencentes ao Grupo 1 e localizadas nos primeiros 25 metros de rocha. 
Segundo Fernandes (1997), fraturas abertas, de baixo ângulo, sub-horizontais, podem ter sido geradas pelo alívio de esforços (descompressão) e pelo intemperismo e dissolução de minerais. Sua presença é mais comum próximo ao topo da rocha e, com o aumento da profundidade, o número de fraturas diminui e suas aberturas tornam-se menores, devido às maiores pressões litostáticas.

Trabalhos prévios sobre a dinâmica do aquífero fraturado da região (IG, 1993) indicam que as fraturas e falhas de direção NE a ENE e NNE, paralelas à foliação, devem ser preferencialmente distensivas, estando relacionadas às principais estruturas condutoras de água nos gnaisses em estudo. A perfuração PP-02 confirma esta afirmação, uma vez que este ponto, apresentou a maior quantidade de água, com vazão estimada em campo de $8 \mathrm{~m}^{3} / \mathrm{h}$ e as fraturas NE-SW são predominantes, principalmente até a profundidade de $62 \mathrm{~m}$.

Fraturas de direção $E-W$ com ângulos de mergulho $>40^{\circ}$ para $S$ (Grupo 3) ou para N (Grupo 7) são também observadas nos trechos de grande variação de velocidade de fluxo.

Desta forma, é possível dizer que a presença destas fraturas no gnaisse local, posicionadas principalmente na porção mais superficial da rocha, auxiliam na interação entre o aquífero freático e o fraturado, contribuindo para a migração dos contaminantes para zonas mais profundas.

Com a perfilagem ótica e cáliper, foi possível verificar algumas fraturas NW-SE possivelmente abertas e sem preenchimento mineral, no entanto, no geral fraturas dessa direção exercem pouca influência sobre o fluxo de água. Neste trabalho, não foi possível realizar a análise do comprimento das fraturas, tendo em vista a metodologia utilizada de investigação dentro do furo.

Diferente dos poços perfurados, o poço tubular P5 apresentou, em maior quantidade, as fraturas do Grupo 8 de direção NNE e mergulho para WNW. Fraturas do Grupo 7 também foram observadas em menor proporção na porção da rocha ainda alterada e fraturas do Grupo 2 foram observadas em profundidade.

A perfilagem realizada com o Flowmeter no PP-01 indicou um fluxo de água ascendente. No entanto, as medições de cargas hidráulicas realizadas com os obturadores indicaram um potencial vertical de fluxo de água descendente entre os intervalos amostrados. Ou seja, a carga hidráulica no nível $A$, medida entre os obturadores no final da amostragem, é maior que as cargas hidráulicas medidas nos níveis $\mathrm{B}$ e $\mathrm{C}$ amostrados. 
O ensaio hidráulico realizado após a instalação do poço PP-01 indicou uma boa recuperação de água, apresentando uma condutividade hidráulica de 1,45×10-6 $\mathrm{m} / \mathrm{s}$. A seção filtrante do poço foi instalada em um intervalo com grande variação de velocidade de água medida pelo Flowmeter. Levando-se em consideração a localização do poço em um alto topográfico e avaliando-se o resultado do ensaio de permeabilidade, juntamente com os resultados dos níveis de água medido com os obturadores, é provável que o fluxo nesta região seja descendente e as fraturas localizadas entre 51,0 e 53,0 m sejam importantes entradas de água.

As medições realizadas com Flowmeter são feitas no furo aberto, ou seja, são resultados de uma média de cargas hidráulicas das fraturas do furo, o que pode mascarar os resultados de sentido de fluxo natural entre as fraturas no aquífero cristalino. Por exemplo, uma fratura mais profunda sob carga hidráulica relativamente maior, quando atingida pela perfuração, pode alterar todo o fluxo de água dentro do furo. Por outro lado, em condições naturais, caso essa fratura não tenha uma conexão hidráulica com as fraturas mais superficiais, ela não irá influenciar o fluxo de água nesta porção mais rasa do aquífero.

No PP-02, assim como observado no PP-01, comparando-se as cargas hidráulicas medidas em cada profundidade entre os obturadores e acima deles, é possível observar um fluxo descendente de água na porção superior da rocha, nos intervalos PP-02A e PP-02B. O intervalo mais profundo amostrado neste ponto (PP02C) está entre 84,5 e 88,2 m de profundidade e apresentou um fluxo ascendente, conforme ilustrado na figura 61. 


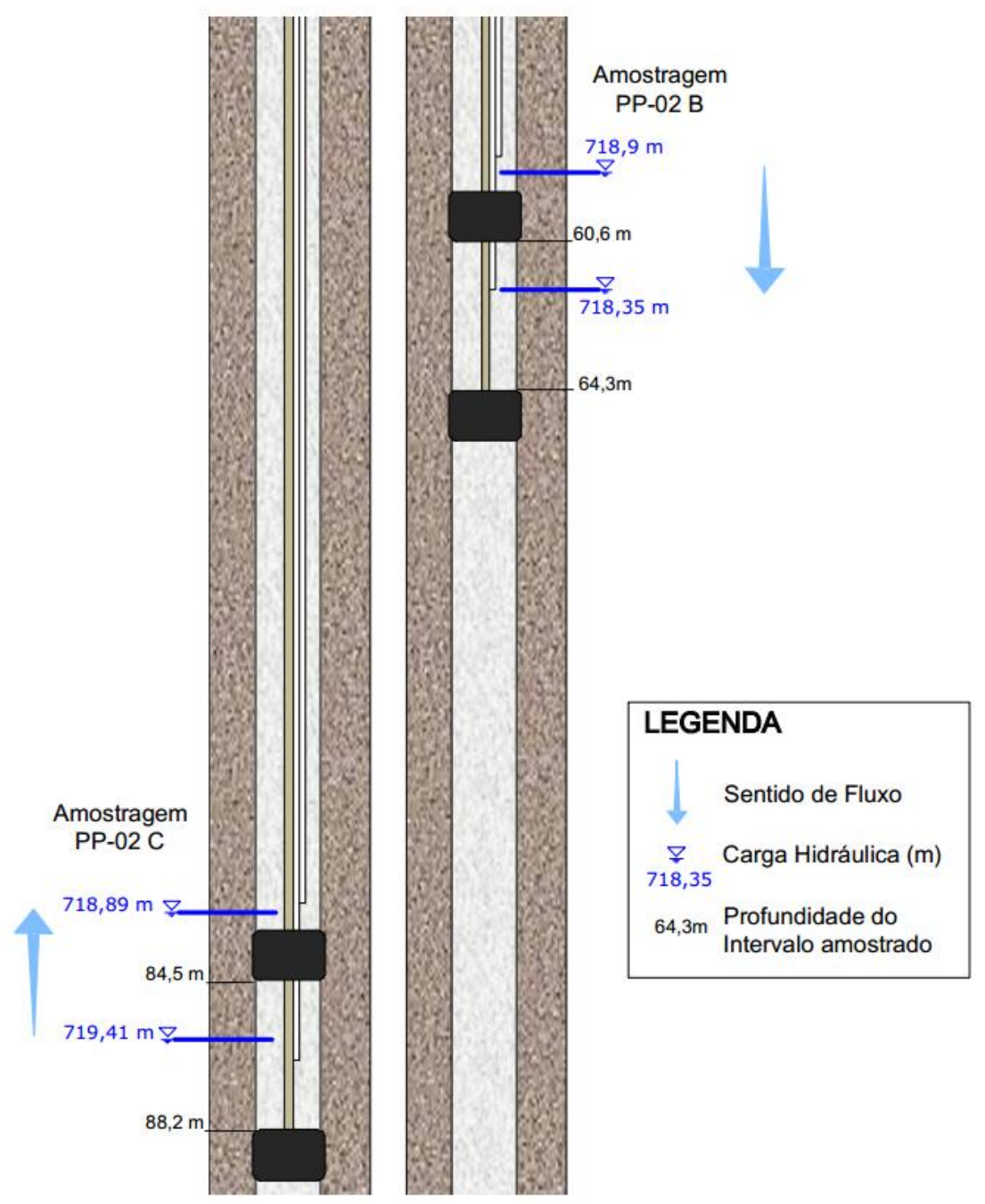

Figura 61 - Nível de água medido durante a amostragem com os obturadores

Conforme discutido no item 6.3 é possível que, devido à boa produção de água neste ponto, o bombeamento por baixa vazão não tenha influenciado significativamente na variação dos níveis de água interno aos obturadores nos níveis A e B.

Considerando os dados apresentados, o perfil de velocidade do Flowmeter (figura 48) deve ser analisado de cima para baixo até a profundidade de $65,0 \mathrm{~m}$ (considerando o fluxo descendente nesta porção), e de baixo para cima no trecho de 65,0 a 92,0 m (considerando o fluxo ascendente nesta região). Assim, a seção filtrante do poço PP-02 instalada na profundidade de 35,35 m até $38,35 \mathrm{~m}$, intercepta uma importante variação de velocidade de fluxo que indica possíveis saídas de água (reduções das velocidades médias observadas).

As amostras de água coletadas indicaram a presença de compostos organoclorados dissolvidos em ambas as perfurações, com maiores concentrações 
no PP-01. A similaridade entre os resultados das análises químicas das amostras coletadas nas diferentes profundidades pode estar relacionada com a interconexão de trechos distintos do aquífero através das fraturas de elevado ângulo de mergulho observadas neste estudo, ou ainda pela má vedação dos obturadores, principalmente no PP-01, gerando assim uma mistura entre as águas nos diferentes trechos coletados. No entanto, as concentrações observadas comprovam a contaminação do aquífero fraturado próximo às principais plumas delimitadas no aquífero raso.

O bombeamento do poço tubular P6 e o rebaixamento de nível de água do poço 54 é mais um indício da conexão hidráulica entre os aquíferos e a influência do bombeamento dos poços tubulares no aquífero raso.

Assim, apesar do fluxo natural descendente entre as fraturas localizadas na porção superior da rocha, o bombeamento dos poços tubulares ao longo dos anos favoreceu o aumento da velocidade de migração das plumas existentes no aquífero raso para porções mais profundas.

Quando se compara o traçado dos lineamentos que atravessam a área de estudo com a ocorrência dos contaminantes observados (figura 60), é possível identificar uma relação dos compostos na água subterrânea com os poços de monitoramentos localizados em uma mesma região estrutural, entre os lineamentos identificados. A contaminação observada no P6, possui maior semelhança com a observada na Área 2, apesar de estar mais próxima da pluma da Área 1. Assim é possível supor que o fluxo de água na região é influenciado e controlado pelas estruturas existentes, que podem estar drenando regionalmente a água subterrânea.

\section{CONCLUSÕES E RECOMENDAÇÕES}

$\mathrm{Na}$ área de estudo, o manto de alteração é composto por material silto-argiloso a arenoso e o topo rochoso foi verificado na profundidade de 39,5 m no PP-01 e de 30,0 m no PP-02. Rochas gnáissicas pertencentes ao complexo Socorro-Guaxupé foram observadas nos dois pontos perfurados. $O$ intervalo mais fraturado corresponde à porção superior da rocha alterada (até aproximadamente $65 \mathrm{~m}$ de profundidade) que possui coloração cinza escura e presença dos minerais biotita, hornblenda, anfibólio, feldspato alcalino e quartzo. Essa porção mais intemperizada apresenta os valores médios mais elevados de emissão da radiação gama, que está 
diretamente relacionado com a presença dos argilominerais resultante da alteração da rocha.

A rocha sã é observada a partir da profundidade de aproximadamente 65,0 metros, e é caracterizada por porções leucossomáticas predominantes, de coloração esbranquiçada, formadas essencialmente por quartzo, feldspato alcalino e plagioclásio, pertencente aos gnaisses da unidade migmatítica intermediária. Em profundidade, os picos de raios gama são observados onde predominam veios mais claros, provavelmente devido à presença de feldspato alcalino, e os menores valores observados são encontrados em porções mais escuras da rocha.

As medidas de foliação observadas em ambas as perfurações apresentam direção entre $\mathrm{N}$ a NE-SW com mergulhos elevados para NW e acompanham a foliação principal das Zonas de Cisalhamento de Valinhos e Campinas do domínio da Nappe Socorro-Guaxupé.

Através da perfilagem acústica foi possível identificar 8 grupos diferentes de fraturas. Fraturas de baixo a médio ângulos de mergulho $\left(<60^{\circ}\right)$ e direção predominante para $\mathrm{N}$ a NE, foram classificadas como Grupo 1, e são as mais frequentes em ambas as perfurações. Estão concentradas principalmente na porção mesossomática, ainda alterada da rocha, porém são também verificadas mais espaçadas em profundidade no PP-02. Essas fraturas foram observadas nos intervalos com as maiores variações de fluxo de água e são possivelmente as principais condutoras de água e contaminantes.

Fraturas de elevado ângulo de mergulho, paralelas à foliação, foram classificadas como Grupo 2 e são observadas a partir de 58,0 m no PP-01, 43,0 m no PP-02 e 56,0 m no P5, sendo no geral mais expressivas em profundidade. Esse grupo possui direção $\mathrm{N}$ a NE-SW com mergulhos para W.

Outro importante grupo de fraturas, o Grupo 3, foi observado nas duas perfurações e apresenta ângulos médio a elevado de mergulho $\left(>45^{\circ}\right)$ e direção predominante E-W a WNW-ESE. As fraturas desse grupo se encontram por toda a extensão do furo no PP-01 e na porção mesossomática no PP-02. Algumas feições desse grupo estão presentes em intervalos importantes de variação de fluxo.

Fraturas do Grupo 4, de direção NE-SW e mergulho entre 55 e 75o para SE, foram observadas em menor quantidade tanto no PP-01 quanto no PP-02. Outras fraturas e grupos de fraturas foram observados, porém de forma mais dispersa e em 
menor quantidade. Fraturas de direção NW-SE foram menos frequentes e pouco expressivas com relação ao fluxo de água.

A perfilagem Flowmeter revelou fluxos ascendentes e velocidade média variando de $0 \mathrm{~m} / \mathrm{min}$ a $1,20 \mathrm{~m} / \mathrm{min}$. Os maiores valores foram registrados no ponto PP-02, mostrando que as fraturas neste local possuem um maior fluxo de água, que é influenciado pelas diferenças de cargas hidráulicas nas fraturas. Em ambos os pontos, observa-se uma tendência de redução de velocidade de água com a profundidade, sendo os maiores valores registrados pelo Flowmeter até a profundidade de $65,0 \mathrm{~m}$.

No entanto, os dados de níveis de água medidos durante a amostragem com os obturadores pneumáticos indicaram um fluxo descendente na porção superior da rocha mais alterada, principalmente nos trechos, PP-01C (entre 57,40 e 61,10 m) e PP-02B (entre 60,60 e 64,3 m). O intervalo mais profundo amostrado (entre 84,50 e $88,20 \mathrm{~m}$ ) indicou um fluxo de água ascendente. Essa porção da rocha sã é caracterizada por variações mais sutis de fluxo, indicando uma menor vazão natural de água.

As amostras de água coletadas com os obturadores indicaram uma mistura de água nas diferentes profundidades, no entanto foi possível confirmar a presença de compostos orgânicos provenientes da contaminação do aquífero freático.

Os ensaios hidráulicos realizados nos poços já instalados, mostraram valores de condutividade hidráulica de $1,45 \times 10^{-6} \mathrm{~m} / \mathrm{s}$ para o PP-01 e de $5,34 \times 10^{-7} \mathrm{~m} / \mathrm{s}$ para 0 PP-02. Analisando o perfil de variação de velocidade média de fluxo (figura 48) e considerando o fluxo de água descendente na porção em que os poços foram instalados, é possível observar que o poço PP-01 está localizado em uma importante zona de entrada de água, ao contrário do PP-02, que apresenta um decréscimo das velocidades observadas pelo Flowmeter (possivelmente associado com importantes saídas de água).

O ensaio de bombeamento realizado no poço tubular existente, mostrou uma rápida variação dos níveis de água no poço raso localizado a aproximadamente 17 m de distância do P6 bombeado. Os dados apresentados indicam que as fraturas presentes em ambos os aquíferos estão hidraulicamente conectadas, provavelmente ocasionando a migração da pluma de contaminação do aquífero raso para porções mais profundas, principalmente em regime de bombeamento. 
Na porção superior da rocha (que possui as maiores velocidades de água), o fluxo natural descendente juntamente com a presença de fraturas baixo ângulo de mergulho de direção N, NE a E, com boas aberturas, intercaladas com fraturas de ângulo médio a subverticais (que são verificadas ao longo de toda perfuração), ocasionaram a migração natural dos contaminantes ao longo do tempo. Em profundidade, apesar do fluxo natural ascendente, o bombeamento dos poços tubulares profundos durante anos, e a presença de fraturas com ângulos elevados de mergulho conectando todo o maciço, favoreceram a migração dos contaminantes para porções mais profundas do aquífero.

No entanto, a complexidade e heterogeneidade das redes de fraturas não permitem que os dados locais obtidos possam ser extrapolados para a área como um todo. A diferença dos Grupos de fraturas identificados no P5 e nos poços perfurados PP-01 e PP-02, ilustram essa afirmação. Os lineamentos estruturais também exercem influência no fluxo de água e transporte de contaminantes. Apesar da proximidade do poço tubular P6 com a Área 1, é possível observar uma semelhança dos contaminantes observados no P6 com os contaminantes observados nos poços da área 2, que estão localizados na mesma região estrutural, entre lineamentos NW.

Assim, tentar entender o caminho da contaminação requer um adensamento da rede de monitoramento do aquífero cristalino, levando em consideração os lineamentos traçados. As novas investigações devem incluir possivelmente a perfuração de sondagens inclinadas, a fim de se diminuir os erros relacionados ao viés de orientação, além da realização de novas perfilagens, ensaios hidráulicos e amostragem discretas.

As amostragens e ensaios hidráulicos devem considerar as adequações necessárias para otimizar as atividades e evitar a mistura de água dentro do furo, compreendendo a utilização de transdutores de pressão ligados a computadores em superfície, utilização de obturadores de maior comprimento e utilização de bomba que possibilite alternância de vazões adequadas para amostragem e para os ensaios.

O entendimento da hidrogeologia do aquífero fraturado a nível local, próximo das fontes de contaminação, e de sua interação com o aquífero raso é de grande importância para o planejamento das etapas posteriores, principalmente 
relacionadas às técnicas de remediação que devem ser avaliadas para o aquífero raso, quando ainda contaminado.

Já a continuidade da investigação do aquífero fraturado para entendimento do fluxo de água e transporte de contaminantes a nível regional, deve ser avaliada com cautela. Além do elevado custo das investigações em profundidade, as informações adicionais coletadas podem ainda não ser representativas a ponto de serem extrapoladas para o restante da área, tendo em vista a heterogeneidade dos aquíferos fraturados. No entanto, esse cenário pode se alterar com o desenvolvimento de novas tecnologias mais eficientes ao longo do tempo, devendo ser reavaliado sempre que necessário.

Diferentemente da investigação de aquíferos porosos, o detalhamento do aquífero fraturado envolve a aplicação de diversas técnicas que devem ser utilizadas em conjunto para que os resultados sejam mais confiáveis, diminuindo as incertezas relacionadas às limitações inerentes de cada técnica, otimizando o tempo das investigações, os recursos financeiros despendidos e tendo sempre em mente quais as respostas esperadas e como elas irão ajudar nas etapas posteriores. 


\section{REFERÊNCIAS BIBLIOGRÁFICAS}

ADAMS, J. A. S.; GASPARINI, P., 1970. Gamma-ray spectrometry of rocks. New York: Elsevier, $295 \mathrm{p}$.

AGÊNCIA NACIONAL DAS ÁGUAS - ANA, 2013. Conjuntura dos Recursos Hídricos no Brasil. Brasília - DF. 432 p.

ALMEIDA, F. F. M.; HASUI, Y.; BRITO NEVES, B. B.; FUCK, R. A., 1977. Províncias Estruturais Brasileiras. In: SBG, Simpósio de Geologia do Nordeste, 8, Campina Grande, Anais, 363-391.

AMERICAN SOCIETY FOR TESTING AND MATERIAL (ASTM). 2002. Standard Practice for Low Flow Purging and Sampling for Wells and Devices Used for Ground Water Quality Investigations. Norma ASTM D-6771-02

BARTON, C.A.; ZOBACK, M.D., MOOS, D. 1995. Fluid flow along potentially active faults in crystaline rock. Geology, 23 (8), p. 683-686.

BEAR, J., 1979. Hydraulics of groundwater. London New York McGraw-Hill International Book Co. 567 p.

BOUWER, H., RICE, R.C. 1976. A slug test for determining hydraulic conductivity of unconfined aquifers with completely or partially penetrating wells. Water Resour. Res. 12, no. 3: $423-428$

CAMPOS NETO, M. C.; BASEI, M.A.S; ALVES, F.R; FIGUEIREDO, M.C.H., 1984. Geologia da Folha Bragança Paulista, 1:50.000. Relatório Final, São Paulo, Convenio IG-USP/PROMINERIO, v.1,162p. (Inédito).

CAMPOS NETO, M.C. \& CABY, R. 2000. Terrane accretion and upward extrusion of highpressure granulites in the Neoproterozoic nappes of Southeast Brazil; petrologic and structural constraints. Tectonics, 19, 669-687.

CAMPOS NETO, M.C., 1991. A porção ocidental da Faixa Alto Rio Grande: ensaio de evolução tectônica. Instituto de Geociências, Universidade de São Paulo, São Paulo, Tese de Doutorado, 210 p.

CAMPOS NETO, M.C.; BASEI, M.A.S.; VLACH, S.R.F.; CABY, R.; SZABÓ, G.A.J.; VASCONCELOS, P. 2004. Migração de orógenos e superposição de orogêneses: um esboço da colagem Brasiliana no sul do Cráton do São Francisco, SE -Brasil. Revista do Instituto de Geociências - USP. Geologia USP, Série Científica, 4, 13-40.

CAVALCANTE, J.C.; CUNHA, H.C.S.; CHIEREGATI, L.A. et al., 1979. Projeto Sapucaí. Relatório Final de Geologia. Brasília: MME/DNPM. Série Geologia 4. 299 p. 
CHO, H.J., R. FIOCCO, DALY, M. 2008. Characterization of Crystalline Bedrock Contaminated by Dense Nonaqueous Liquid (Abstract). Ground Water Remediation and Monitoring 28(2):49-59(2008)

COMPANHIA AMBIENTAL DO ESTADO DE SÃO PAULO - CETESB, 2001. Manual de Gerenciamento de Áreas Contaminadas, Projeto CETESB - GTZ cooperação Técnica Brasil-Alemanha.

COMPANHIA AMBIENTAL DO ESTADO DE SÃO PAULO - CETESB, 2014. Valores Orientadores para solo e água subterrânea no estado de São Paulo.

COMPANHIA AMBIENTAL DO ESTADO DE SÃO PAULO - CETESB; AGÊNCIA NACIONAL DE ÁGUAS (ANA). 2011. Guia Nacional de Coleta e Preservação de Amostras. Água, Sedimento, Comunidades Aquáticas e Efluentes Líquidos. São Paulo: CETESB; Brasília: ANA.

COOPER, H.H., BREDEHOEFT, J.D., PAPADOPULOS, I.S. 1967. Response of a finite diameter well to an instantaneous charge of water. Water Resour. Res. 3, no. 1:263-269.

CPRM - SERVIÇO GEOLÓGICO DO BRASIL. 2006. Mapa Geológico do Estado de São Paulo. Ministério de Minas e Energia - Secretaria de Geologia, Mineração e Transformação Mineral. Brasilia. Escala 1:750.000.

CUSTODIO, E.; LLAMAS, M. 1996. Hidrología Subterránea. 2. ed. Barcelona: Omega, 2v.

DOMENICO, P. \& SCHWARTZ, F. 1990. Physical and chemical hydrogeology. John Wiley\& Sons, Nova York. 824 p.

FEITOSA, F.A.C.; MANOEL FILHO, J. (Org.) 2000. Hidrogeologia: conceitos e aplicações. Recife: CPRM, LABHID-UFPE. Livro digital

FERNANDES, A.J. 1997. Tectônica Cenozóica na porção média da bacia do Rio Piracicaba e sua aplicação à hidrogeologia. Tese de Doutoramento - Instituto de Geociências da Universidade de São Paulo.

FERNANDES, A. J. 2008. Aquíferos fraturados: uma revisão dos condicionantes geológicos e dos métodos de investigação. Revista do Instituto Geológico, São Paulo, v. 29 (1/2), p. 4972.

FETTER, C. W. 2001. Applied Hydrogeology. Prentice Hall, 2001. 598 p

FETTER, C. W. 2008. Contaminant Hydrogeology. 2nd Ed. Long Grove, Illinois: Waveland Press Inc., 500p. 
FIUME, B. 2013. Geologia de detalhe para elaboração de modelo conceitual de circulação de água subterrânea: estudo de caso em Jurubatuba, SP. Dissertação de Mestrado, Instituto de Geociências, Universidade de São Paulo.

FREEZE, R.A. \& CHERRY, J.A. 1979. Groundwater. 604 pp. Prentice Hall, New Jersey, USA.

GUERRA, K.J. 2010. Aplicação de método geofísico em estudo hidrogeológico no município de Nova Lima - MG: caracterização de aquíferos em área urbana. Dissertação (Mestrado), Instituto de Geociências, Universidade Federal de Minas Gerais, Belo Horizonte, 116 p.

HESS, A. E. 1990. Thermal-pulse Flowmeter for Measuring Slow Water Velocities in Boreholes. U.S. GEOLOGICAL SURVEY. Open-File Report 87-121

HESS, A. E., F. L. PAILLET. 1990. Applications of the thermal-pulse flowmeter in the hydraulic characterization of fractured rocks. Pp. 99-112 in Geophysical Applications for Geotechnical Investigations, F. L. Paillet and W. R. Saunders, eds. ASTM STP 1101. Philadelphia, Pa.: American Society for Testing and Materials.

HOEK E; BRAY J. W. 2005. Rock Slope Engineering. Institution of Mining and Metallurgy, 4. ed. London, 402p.

HOLLOWAY, O.G., and Waddell, J.P., 2008. Design and operation of a borehole straddle packer for ground-water sampling and hydraulic testing of discrete intervals at U.S. Air Force Plant 6, Marietta, Georgia: U.S. Geological Survey Open-File Report 2008 - 1349, 24 p., Disponível em <http://pubs.usgs.gov/of/2008/1349/>. Acesso em: 16 de abril, 2015.

HUBBARD, B., ROBERSON, S., SAMYN, D., MERTON-LYN, D. 2008. Instruments and Methods Digital optical televiewing of ice boreholes. Journal of Glaciology, Vol. 54, No. 188.

HVORSLEV, M.J., 1951. Time Lag and Soil Permeability in Ground-Water Observations, Bull. No. 36, Waterways Exper. Sta. Corps of Engrs, U.S. Army, Vicksburg, Mississippi, pp. $1-50$

INSTITUTO GEOLÓGICO - IG, 1993. Subsídio do Meio Físico Geológico ao Planejamento de Campinas - SP. Relatório técnico, volume II.

JOHNSON, C. D., HAENI, F. P., LANE, J. W., WHITE, E. A. 2002. Borehole-geophysical investigation of the University of Connecticut landfill, Storrs, Connecticut: U.S. Geological Survey, Water Resources Investigations Report 01-4033, 187 p.

KEYS, W. S. 1968. Well Logging in Ground-Water Hydrology. Ground Water, 6: 10-18

KEYS, W. S. 1990. Borehole geophysics applied to ground-water investigations. US 
Geological Survey, Techniques of Water-Resources Investigations, Book 2, Chapter E2, 149 p.

KUEPER B. H.; WEALTHALL G. P.; SMITH J.W.N.; LEHARNE, S.A.; LERNER D.N. 2003. An Illustrated Handbook of DNAPL Transport and Fate in the Subsurface. Environment Agency, United Kingdom. R\&D Publication 133, 67 pp

LAWN, B. R. \& WILSHAW, T. R. 1993. Fracture of Brittle Solids. Second Edition Cambridge University Press, London, 378 p.

MINTY, B.R.S. 1997. The fundamentals of airborne gammaray spectrometry. AGSO Journal of Australian Geology and Geophysics, v. 17, n. 2, p. 39-50.

NERY, G.G. \& MACARI, R. 2006. Estudo do comportamento da perfilagem ótica e geofísica na Formação Serra Geral. In: Associação Brasileira de Águas Subterrâneas, Congresso Brasileiro de Águas Subterrâneas, 14, Suplemento.

NEUMAN, S. P., 2005. Trends, prospects and challenges in quantifying flow and transport through fractured rocks, Hydrogeol. J., 13, 124-147.

NEVES, A. M. 2005. Análise Integrada Aplicada à Exploração de Água subterrânea na Bacia do Rio Jundiaí (SP). 200f. Tese (doutoramento). Instituto de Geociências e Ciências Exatas, Universidade Estadual Paulista, Rio Claro, São Paulo.

NOVAKOWSKI, K. 1995. Groundwater flow in fractured rocks. Waterloo Centre for Ground Water Research, Canada. Course Notes.46 p.

OZONE SECRETARIAT. UNEP. Disponível em: <http://ozone.unep.org/en/handbookmontreal-protocol-substances-deplete-ozone-layer/12 >. Acesso em: 02 março de 2015.

PAILLET, F. L, HESS, A. E., CHENG, C. H., HARDIN, E., 1987. Characterization of fracture permeability with high-resolution vertical flow measurements during borehole pumping. Ground Water 25 (1), 28 - 40.

PAILLET, F. L. \& OLLILA, P. 1994. Identification, characterization and analysis of hydraulic conductive fractures of granitic basement rocks, Massachusetts. U.S. Geological Survey, Water Resources Investigation Report 94-4185. 38 p.

PAILLET, F. L. 1994. Application of borehole geophysics in the characterization of flow in fractured rocks, U.S. Geological Survey Water Resources Investigation Report 93-4214, 36 p.

PAILLET, F. L., 1995. Using borehole flow logging to optimize hydraulic-test procedures in heterogeneous fractured aquifers. Hydrogeology Journal, 3: 4-20. 
PAILLET, F. L.; BARTON, C.; LUTHI, S.; RAMBOW, F.; ZEMANEK, J. 1990. Borehole Imaging. Society of Professional Well Log Analysts, SPWLA Reprint Series, Houston, Texas, $472 \mathrm{p}$.

PAILLET, F. L.; CROWDER, R.; HESS, A. E. 1994. High resolution flowmeter logging - a unique combination of borehole geophysics and hydraulics. In: Symposium on the application of Geophysics to Engineering and Environmental Problems, Proceedings, 381 404.

PANKOW, J. F., CHERRY, J. A. 1996. Dense Chlorinated Solvents and Other DNAPLs in Groundwater: History, Behavior, and Remediation. Portland, Oregon: Waterloo Press. 525 p.

PARKER, B. L. 2007. Investigating Contaminated Sites on Fractured Rock Using the DFN Approach. Fractured Rock Conference: State of the Science and Measuring Success in Remediation, September 24-26, Portland, Maine. 150-168.

PARKER, B. L.; CHERRY, J. A.; CHAPMAN, S, W. 2012. The Discrete Fracture Network Approach for Studying Contamination in Fractured Rock. AQUA mundi - Am06052: 101 116.

PINO, D.S. 2012. Structural Hydrogeology in the Kenogamy Uplands, Quebec, Canada. Thesis (Master), L'Université du Québec à Chicoutimi, Quebec, 184 p.

RIBEIRO, L. A. F. S. 2012. Perfilagens geofísica de poços tubulares profundos. Região do canal Jurubatuba, São Paulo (SP). Trabalho de conclusão de curso.

SCHWARZENBACH, R. P. et al. 2005. Environmental Organic Chemistry. Second Edition. Hoboken, New Jersey:John Wiley \& Sons, Inc. 1328 p.

SHAPIRO, A.M.; 2001. Characterizing Ground-Water Chemistry and Hydraulic Properties of Fractured-Rock Aquifers Using the Multifunction Bedrock-Aquifer Transportable Testing Tool (BAT3), United States Geological Survey Fact Sheet FS-075-01, 4p

SNOW, D.T. 1969. Anisotropic permeability of fractured media. Water Resources Research, Washington, v. 5, n.6, p.1273-1289.

STERLING, S. N., et al. 2005. Vertical Cross Contamination of Trichloroethylene in a Borehole in Fractured Sandstone. Ground Water 43:557-573.

STEWART, L.M., 2000, Laboratory analytical results for ground-water sampling at Southern Polytechnic State University, Marietta, Georgia, 1997, U.S. Geological Survey Open-File Report 00-277, 28 p. 
STUMM, F.; CHU, A.; LANGE, A.D.; PAILLET, F.L.; WILLIAMS, J.H.; LANE Jr, J.W. 2001. Use of advanced borehole geophysical techniques to delineate fractured-rock ground-water flow and fractures along water-tunnel facilities in northern Queens County, New York. U.S. Geological Survey, Water-Resources Investigations Report 00-4276, 12 p.

SUTHERSAN, S; PAYNE, F. 2005. In Situ Remediation Engineering. Boca Raton, Fla, CRC Press. $532 \mathrm{p}$.

TASK GEOSCIENCE, 2008. Borehole bias explained. Disponível em: http://www.indabook.org/d/Bias-Attitude.pdf. Acesso em: 06 de agosto, 2015.

TERZAGHI, R.D. 1965. Sources of error in joint surveys. Géotechnique, 15(3): 287-304.

ULBRICH, H. H. G. J.; ULBRICH, M. N. C.; FERREIRA, F. J. F.; ALVES, L. S.; GUIMARÃES, G. B.; FRUCHTING, A.. 2009. Levantamentos gama espectrométricos em granitos diferenciados. I: revisão da metodologia e do comportamento geoquímico dos elementos K, Th e U. Geologia USP. Série Científica, v. 9, n. 1, p. 33-53.

UNITED STATES ENVIRONMENTAL PROTECTION AGENCY (USEPA). 1998 Technical Protocol for Evaluating Natural Attenuation of Chlorinated Solvents in Ground Water. Washington DC. United States. EPA/600/R-98/128. Disponível em: http://www3.epa.gov/epawaste/hazard/correctiveaction/resources/guidance/rem eval/protoc ol.pdf.

UNITED STATES ENVIRONMENTAL PROTECTION AGENCY (USEPA). 2004 Performance Monitoring of MNA Remedies for VOCs in Ground Water. National Risk Management Research Laboratory (NRMRL), Ada, Oklahoma, Publication EPA/600/R04/027, 92p. Disponível em: http://nepis.epa.gov/Adobe/PDF/10004FKY.pdf

VAZ, L.F. 1996. Classificação genética dos solos e dos horizontes de alteração de rocha em regiões tropicais. Solos e Rochas, São Paulo, 19, (2): p. 117-136.

VLACH, S. R. F. 1993. Geologia e petrologia dos Granitóides Morumgaba, SP. 414 pp. Tese de Doutoramento, Instituto de Geociências da Universidade de São Paulo.

WAHNFRIED, I. 2010. Modelo conceitual de fluxo do aquitarde Serra Geral e do Sistema Aquífero Guarani na região de Ribeirão Preto-SP. 135 f. Tese (doutoramento) - Instituo de geociências, Universidade de São Paulo, São Paulo.

WATERLOO BRASIL, Abril de 2014 - Campanha de Monitoramento da Água SubterrâneaP.1383-3609/14. 
WATERLOO BRASIL, Dezembro de 2011. Estudo Geológico e Mapeamento do Topo Rochoso - P1059-2719/11.

WATERLOO BRASIL, Março de 2011. Investigação Ambiental Detalhada e Monitoramento Geral - P.916-2369/10 e P.965-2594/10;

WIEDEMEIER, T. H.; RIFAI, H. S., NEWELL, C. J.; WILSON, J. T. 1999. Natural Attenuation of Fuels and Chlorinated Solvents in the Subsurface. Hoboken, NJ:John Wiley \& Sons. 632 p.

WILLIAMS J.H. \& JOHNSON C.D., 2004 Acoustic and optical borehole-wall imaging for fractured-rock aquifer studies: Journal of Applied Geophysics, vol. 55, Issue 1-2, p. 151-159. 
ANEXO 1 - Compilação das perfilagens 


\section{PP-01}

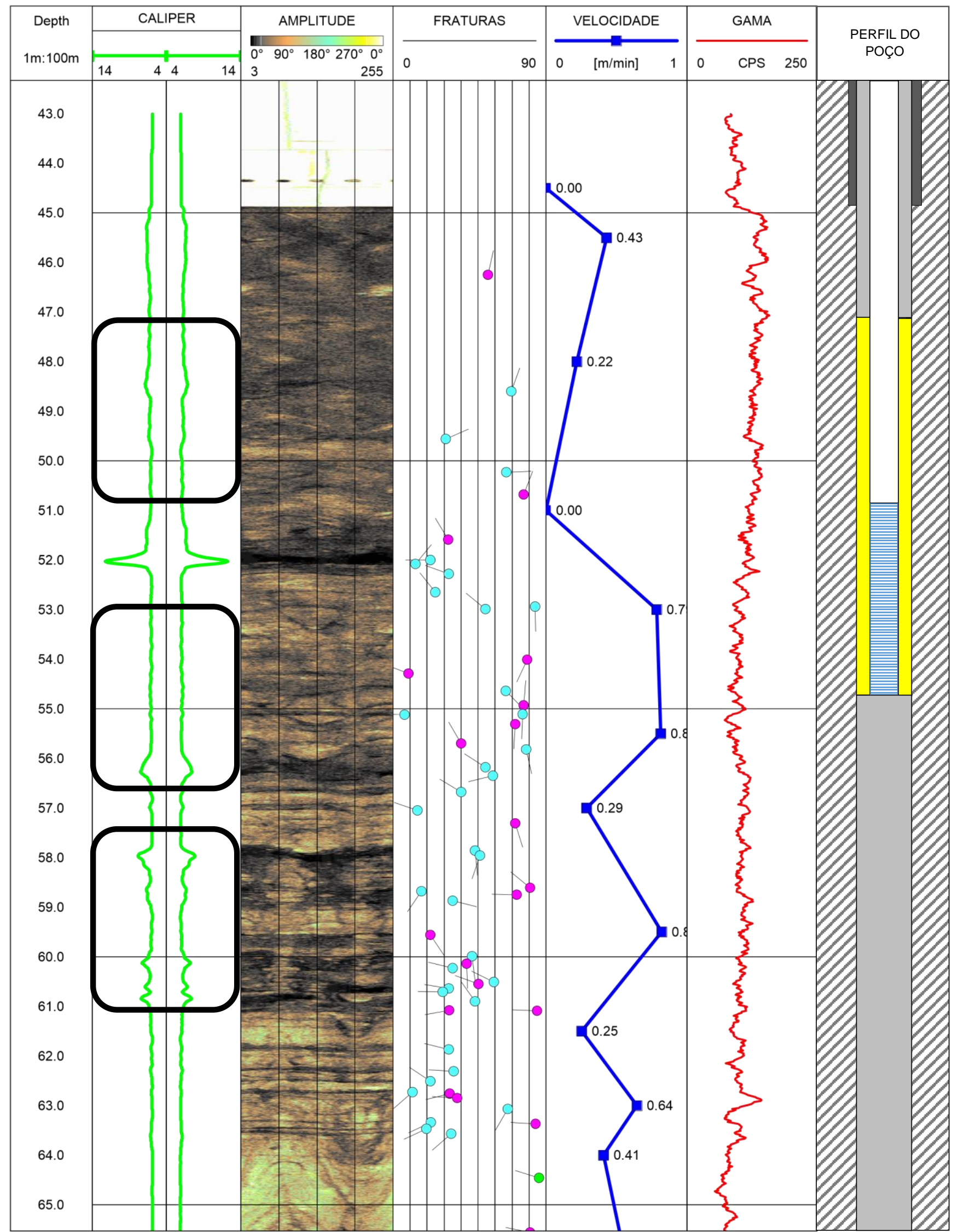




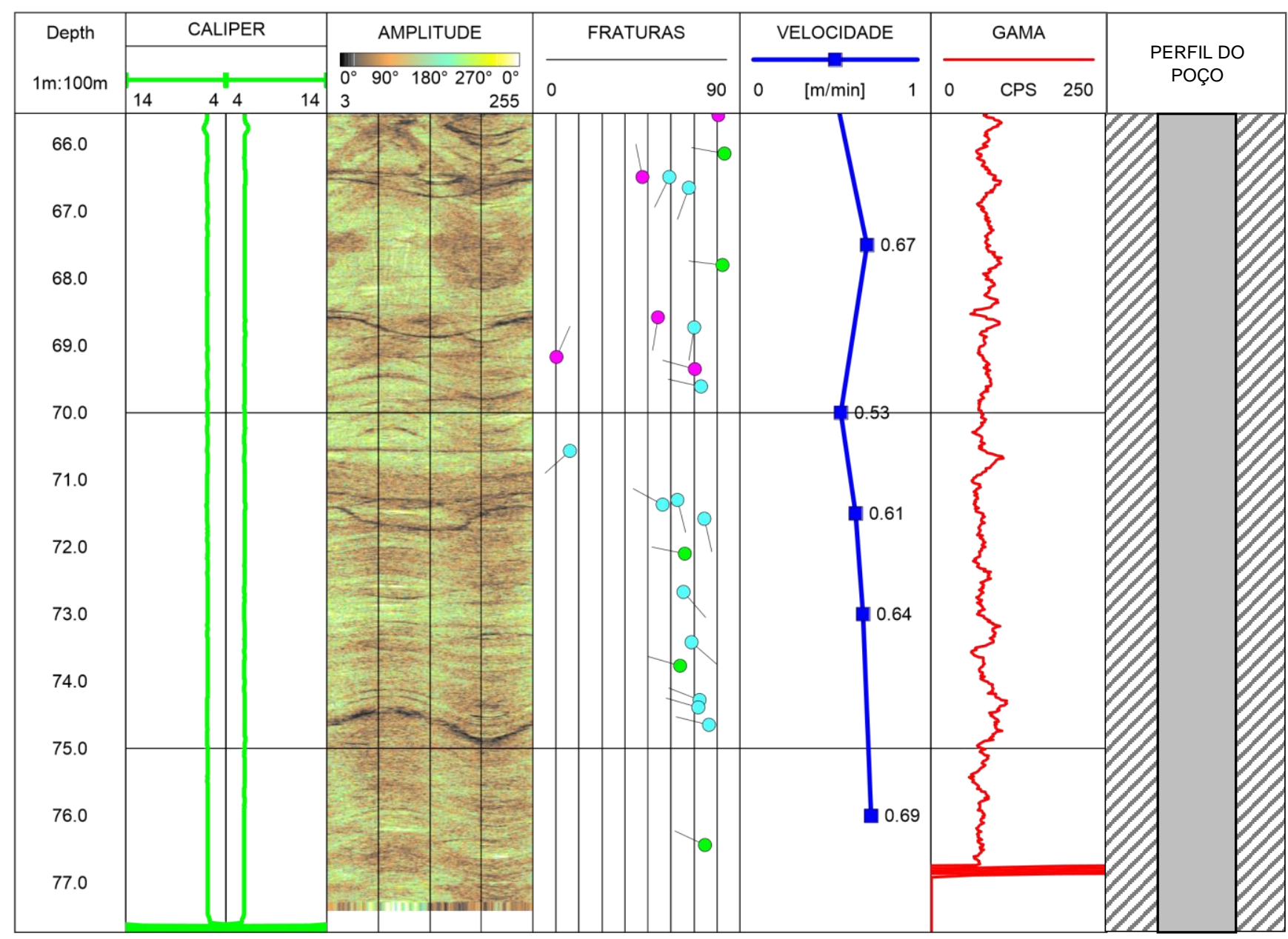

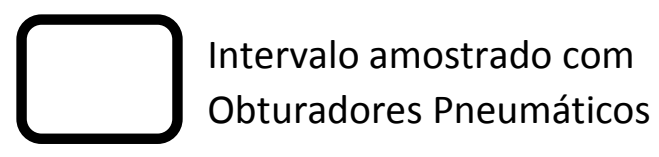

Fraturas

Possíveis Fraturas

Foliações

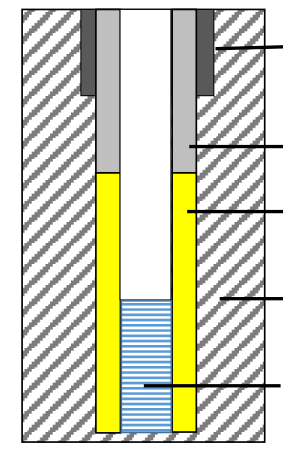

Revestimento de aço

Selo de calda de cimento

Pré-Filtro (areia)

Gnaisse

Filtro: tubo de PVC geomecânico ranhurado 
PP-02

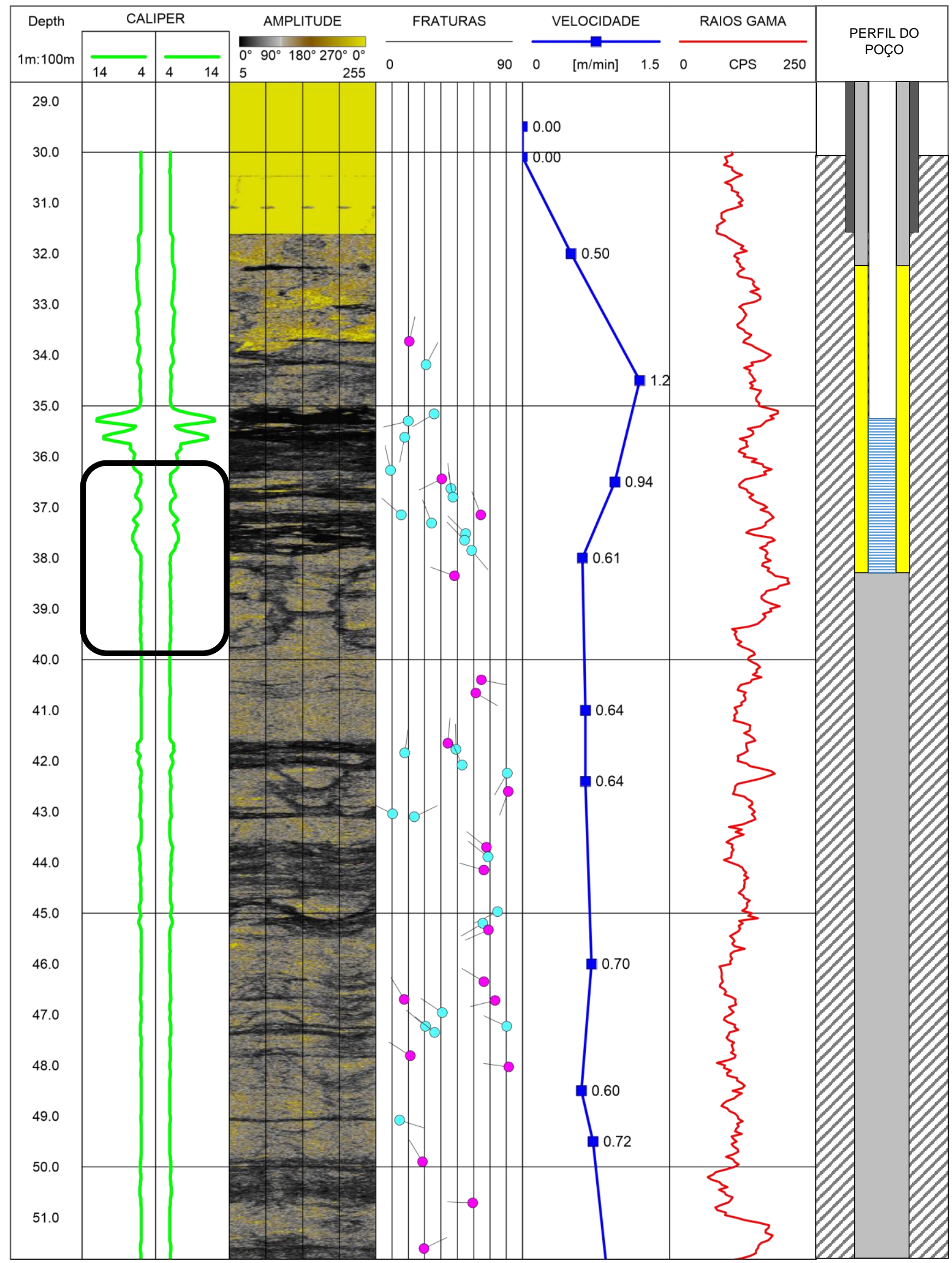




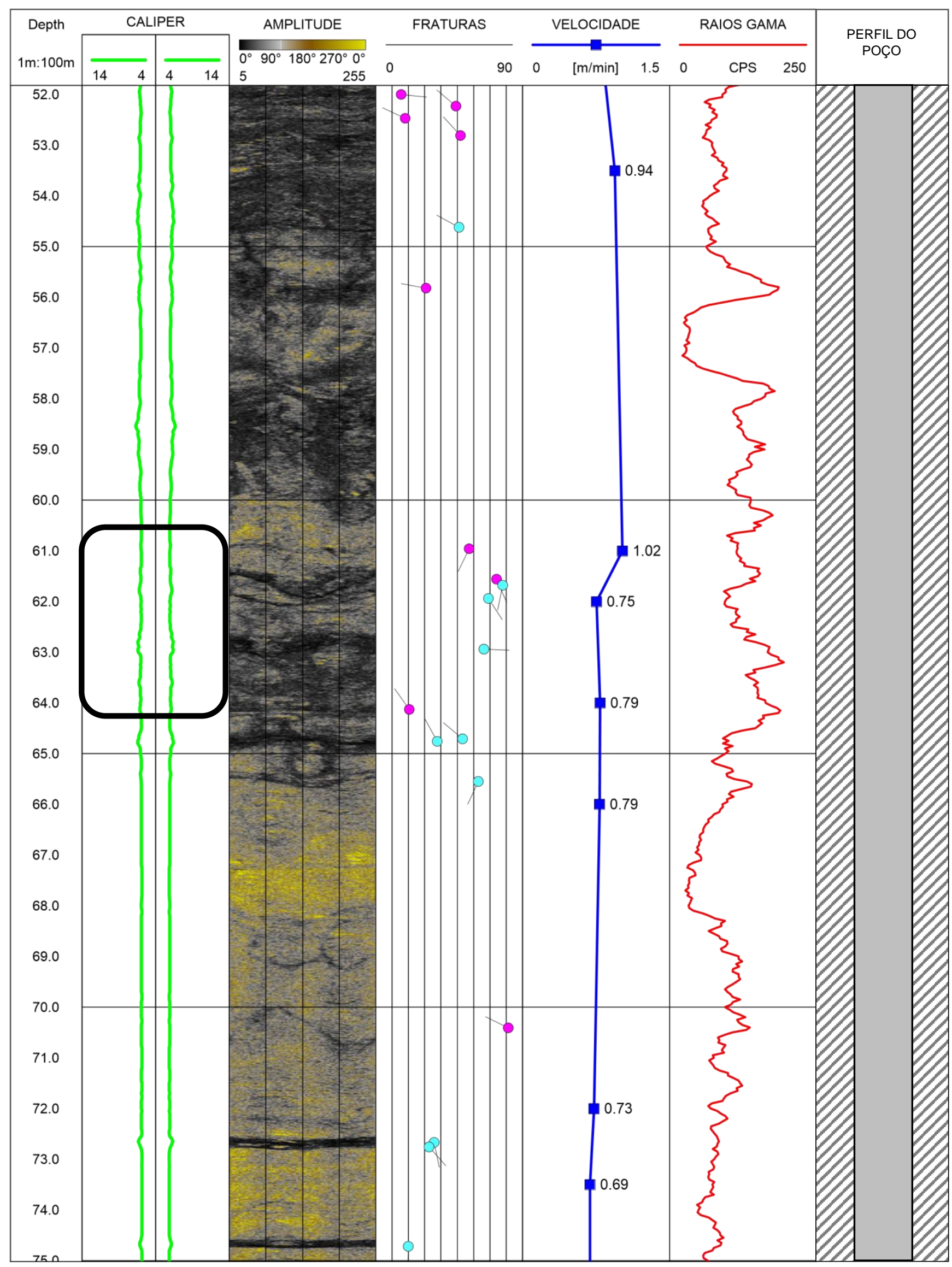




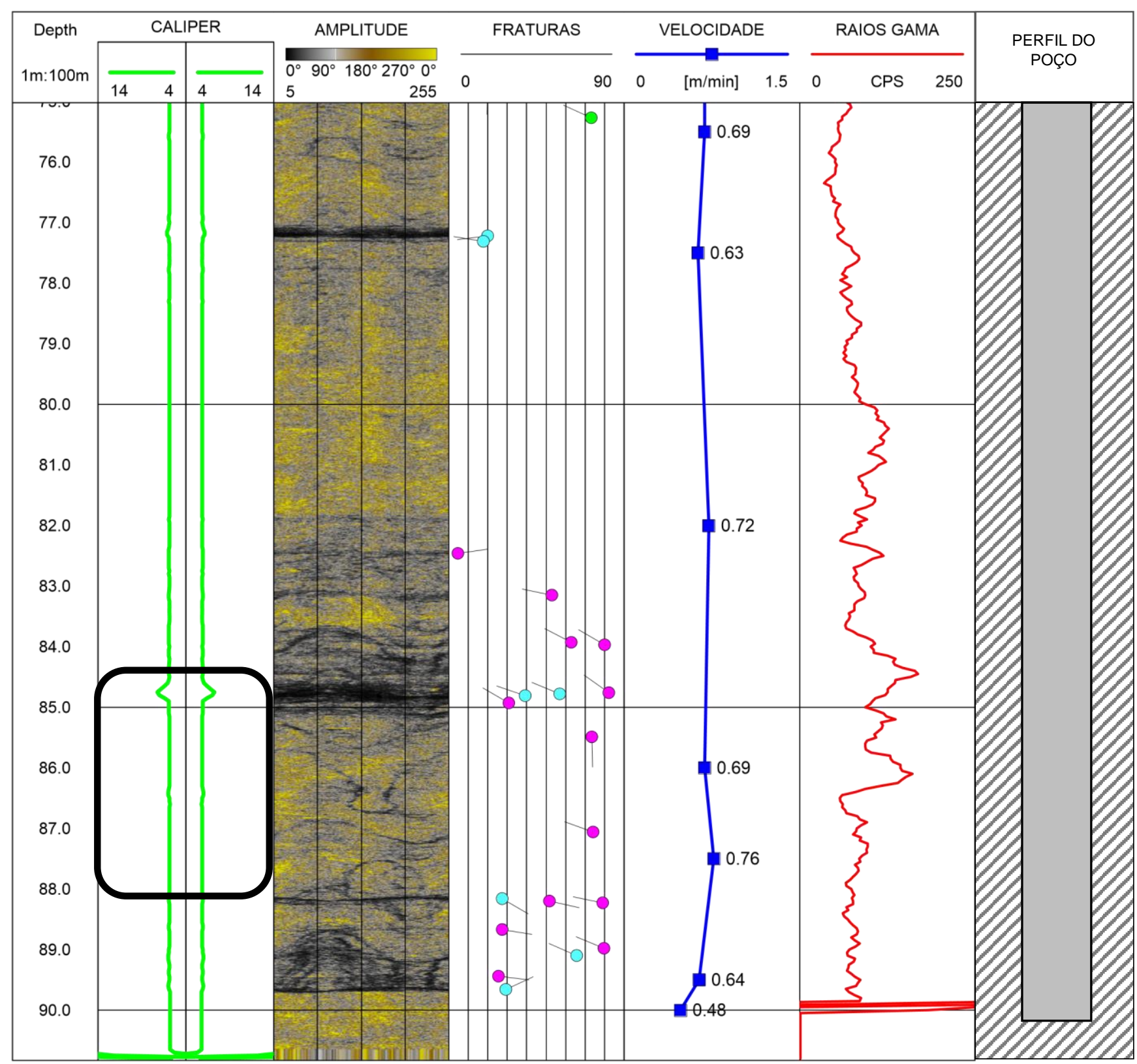
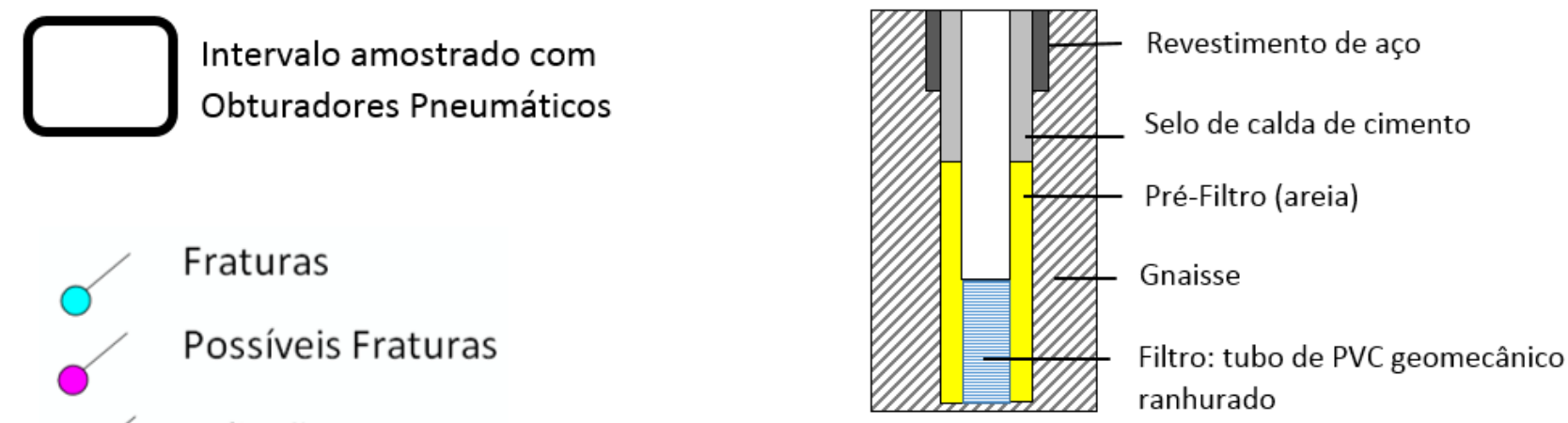

Foliações 



\section{P5}

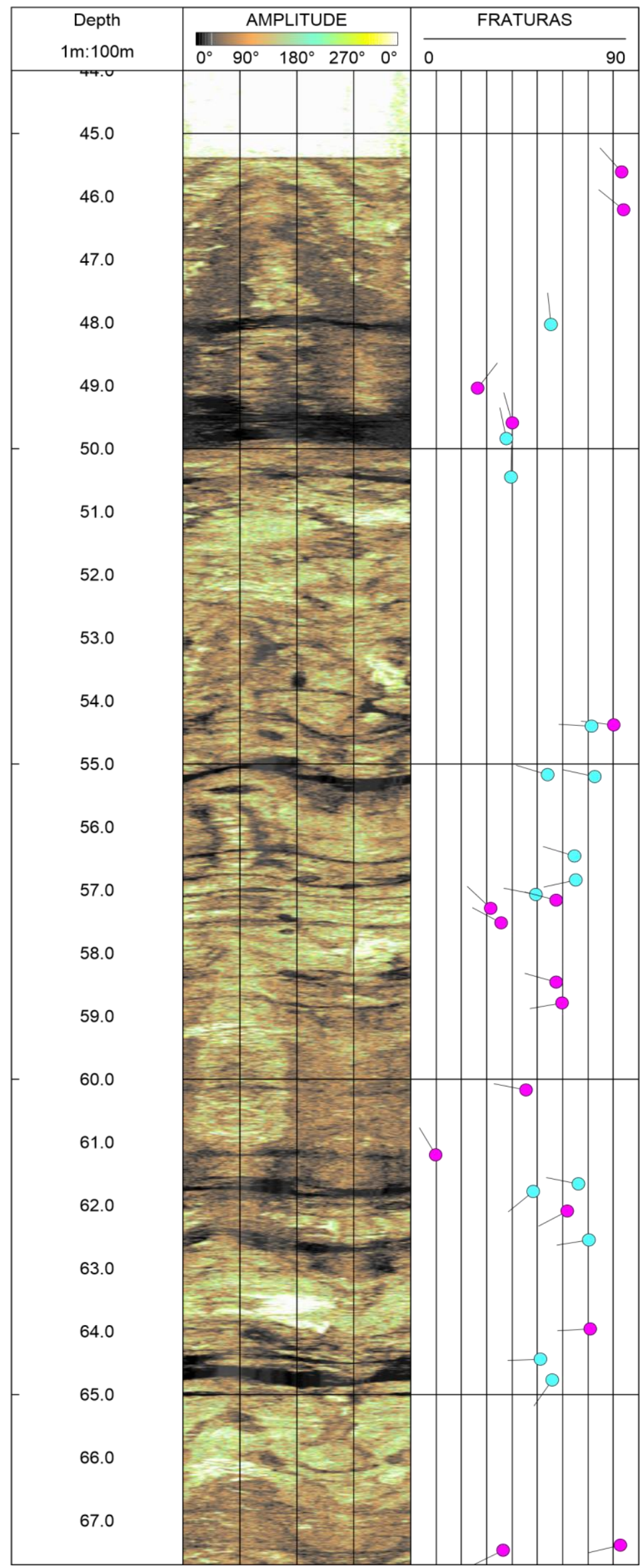




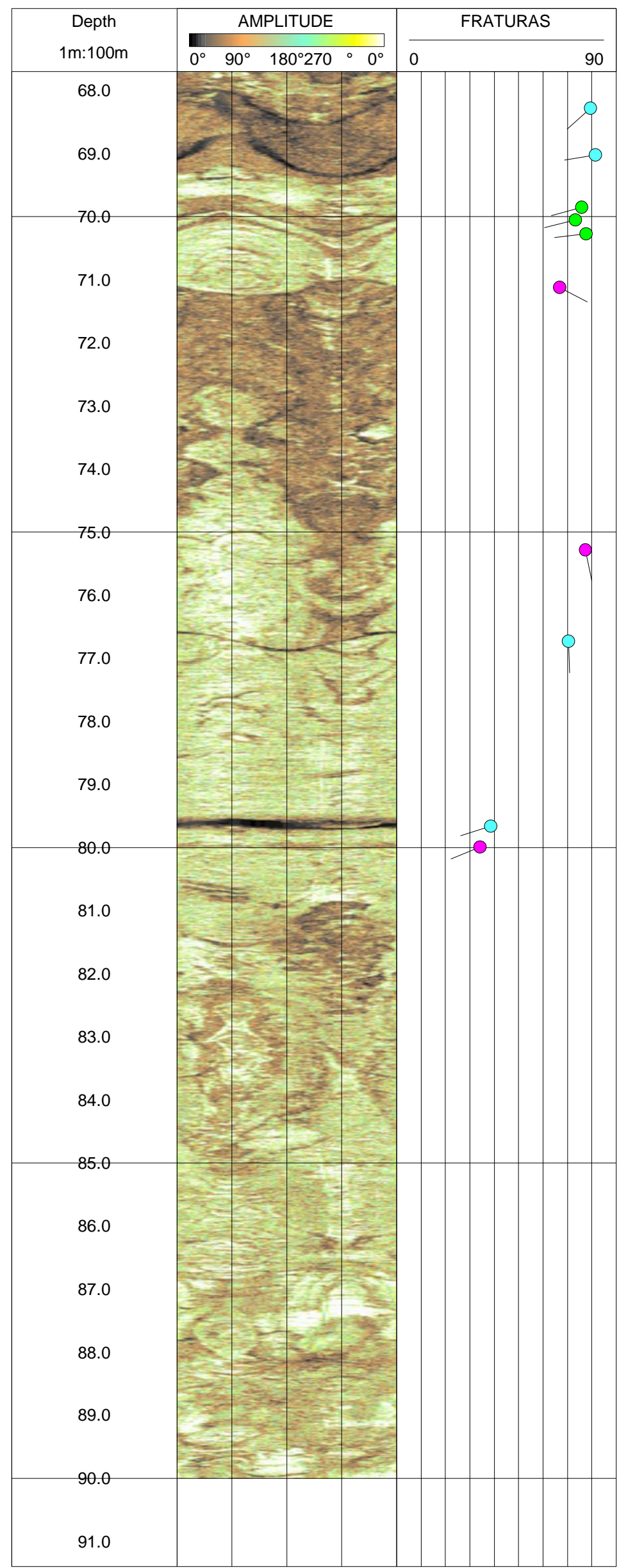

Fraturas

Possíveis Fraturas

Foliações 
ANEXO 2 - Feições Identificadas pelas perfilagens 
Tabela 1: Dados estruturais do ponto PP-01.

\begin{tabular}{|c|c|c|c|c|c|}
\hline PROF. (m) & AZIMUTE $\left({ }^{\circ}\right)$ & DIP $\left({ }^{\circ}\right)$ & DIREÇÃO & MERGULHO & CLASSIFICAÇÃO \\
\hline 46,26 & 13 & 56 & E-W & $\mathrm{N}$ & Possível fratura \\
\hline 48,61 & 20 & 70 & $\mathrm{E}-\mathrm{W}$ & $\mathrm{N}$ & Fratura \\
\hline 49,56 & 66 & 31 & NW-SE & NE & Fratura \\
\hline 50,24 & 87 & 67 & $\mathrm{~N}-\mathrm{S}$ & $E$ & Fratura \\
\hline 50,69 & 21 & 77 & $E-W$ & $\mathrm{~N}$ & Possível fratura \\
\hline 51,6 & 329 & 32 & NE-SW & NW & Possível fratura \\
\hline 52,01 & 270 & 22 & $\mathrm{~N}-\mathrm{S}$ & W & Fratura \\
\hline 52,09 & 39 & 13 & NW-SE & NE & Fratura \\
\hline 52,28 & 290 & 33 & $\mathrm{~N}-\mathrm{S}$ & W & Fratura \\
\hline 52,66 & 322 & 25 & NE-SW & NW & Fratura \\
\hline 52,95 & 179 & 84 & $\mathrm{E}-\mathrm{W}$ & $S$ & Fratura \\
\hline 52,99 & 309 & 54 & NE-SW & NW & Fratura \\
\hline 54,01 & 205 & 79 & NW-SE & SW & Possível fratura \\
\hline 54,29 & 291 & 9 & $\mathrm{~N}-\mathrm{S}$ & W & Possível fratura \\
\hline 54,64 & 136 & 66 & NE-SW & SE & Fratura \\
\hline 54,94 & 4 & 77 & E-W & $\mathrm{N}$ & Possível fratura \\
\hline 55,11 & 183 & 76 & $\mathrm{E}-\mathrm{W}$ & $S$ & Fratura \\
\hline 55,12 & 272 & 7 & $\mathrm{~N}-\mathrm{S}$ & $W$ & Fratura \\
\hline 55,32 & 184 & 72 & $E-W$ & $S$ & Possível fratura \\
\hline 55,7 & 330 & 40 & NE-SW & NW & Possível fratura \\
\hline 55,82 & 167 & 78 & E-W & $S$ & Fratura \\
\hline 56,19 & 303 & 54 & NE-SW & NW & Fratura \\
\hline 56,35 & 256 & 59 & $\mathrm{~N}-\mathrm{S}$ & $W$ & Fratura \\
\hline 56,68 & 302 & 40 & NE-SW & NW & Fratura \\
\hline 57,06 & 289 & 14 & $\mathrm{~N}-\mathrm{S}$ & W & Fratura \\
\hline 57,31 & 163 & 72 & E-W & $S$ & Possível fratura \\
\hline 57,87 & 174 & 48 & $E-W$ & $S$ & Fratura \\
\hline 57,97 & 198 & 51 & $E-W$ & $S$ & Fratura \\
\hline 58,62 & 309 & 81 & NE-SW & NW & Possível fratura \\
\hline 58,68 & 214 & 17 & NW-SE & SW & Fratura \\
\hline 58,75 & 271 & 73 & $\mathrm{~N}-\mathrm{S}$ & W & Possível fratura \\
\hline 58,88 & 104 & 35 & $\mathrm{~N}-\mathrm{S}$ & $E$ & Fratura \\
\hline 59,56 & 147 & 22 & NE-SW & SE & Possível fratura \\
\hline 60 & 173 & 47 & $E-W$ & $S$ & Fratura \\
\hline 60,15 & 178 & 43 & E-W & $S$ & Possível fratura \\
\hline 60,24 & 284 & 35 & $\mathrm{~N}-\mathrm{S}$ & $W$ & Fratura \\
\hline 60,51 & 296 & 59 & NE-SW & NW & Fratura \\
\hline 60,56 & 290 & 50 & $\mathrm{~N}-\mathrm{S}$ & $W$ & Possível fratura \\
\hline 60,65 & 279 & 33 & $\mathrm{~N}-\mathrm{S}$ & W & Fratura \\
\hline 60,71 & 271 & 29 & $\mathrm{~N}-\mathrm{S}$ & W & Fratura \\
\hline 60,91 & 325 & 48 & NE-SW & NW & Fratura \\
\hline 61,09 & 260 & 33 & $\mathrm{~N}-\mathrm{S}$ & $W$ & Possível fratura \\
\hline
\end{tabular}




\begin{tabular}{|c|c|c|c|c|c|}
\hline PROF. (m) & AZIMUTE $\left({ }^{\circ}\right)$ & DIP $\left(^{\circ}\right)$ & DIREÇÃO & MERGULHO & CLASSIFICAÇÃO \\
\hline 61,09 & 272 & 85 & $\mathrm{~N}-\mathrm{S}$ & $W$ & Possível fratura \\
\hline 61,87 & 284 & 33 & $\mathrm{~N}-\mathrm{S}$ & W & Fratura \\
\hline 62,31 & 274 & 36 & $\mathrm{~N}-\mathrm{S}$ & W & Fratura \\
\hline 62,51 & 304 & 22 & NE-SW & NW & Fratura \\
\hline 62,74 & 229 & 11 & NW-SE & SW & Fratura \\
\hline 62,77 & 256 & 33 & $\mathrm{~N}-\mathrm{S}$ & W & Possível fratura \\
\hline 62,86 & 274 & 38 & $\mathrm{~N}-\mathrm{S}$ & $W$ & Possível fratura \\
\hline 63,08 & 210 & 67 & NW-SE & SW & Fratura \\
\hline 63,34 & 245 & 22 & NW-SE & SW & Fratura \\
\hline 63,38 & 274 & 84 & $\mathrm{~N}-\mathrm{S}$ & W & Possível fratura \\
\hline 63,47 & 245 & 20 & NW-SE & SW & Fratura \\
\hline 63,57 & 229 & 34 & NW-SE & SW & Fratura \\
\hline 64,47 & 287 & 86 & $\mathrm{~N}-\mathrm{S}$ & W & Foliação \\
\hline 65,56 & 281 & 81 & $\mathrm{~N}-\mathrm{S}$ & W & Possível fratura \\
\hline 66,14 & 280 & 83 & $\mathrm{~N}-\mathrm{S}$ & W & Foliação \\
\hline 66,48 & 206 & 59 & NW-SE & SW & Fratura \\
\hline 66,49 & 348 & 48 & E-W & $\mathrm{N}$ & Possível fratura \\
\hline 66,65 & 200 & 68 & E-W & $S$ & Fratura \\
\hline 67,79 & 277 & 82 & $\mathrm{~N}-\mathrm{S}$ & $W$ & Foliação \\
\hline 68,57 & 189 & 54 & E-W & $S$ & Possível fratura \\
\hline 68,73 & 189 & 70 & $E-W$ & $S$ & Fratura \\
\hline 69,17 & 23 & 10 & NW-SE & NE & Possível fratura \\
\hline 69,34 & 285 & 70 & $\mathrm{~N}-\mathrm{S}$ & $W$ & Possível fratura \\
\hline 69,61 & 282 & 73 & $\mathrm{~N}-\mathrm{S}$ & $W$ & Fratura \\
\hline 70,56 & 229 & 16 & NW-SE & SW & Fratura \\
\hline 71,3 & 166 & 63 & $E-W$ & $S$ & Fratura \\
\hline 71,37 & 299 & 56 & NE-SW & NW & Fratura \\
\hline 71,57 & 167 & 74 & E-W & $S$ & Fratura \\
\hline 72,1 & 281 & 66 & $\mathrm{~N}-\mathrm{S}$ & $\mathrm{W}$ & Foliação \\
\hline 72,66 & 139 & 66 & NE-SW & SE & Fratura \\
\hline 73,41 & 131 & 69 & NE-SW & SE & Fratura \\
\hline 73,76 & 286 & 64 & $\mathrm{~N}-\mathrm{S}$ & W & Foliação \\
\hline 74,27 & 292 & 72 & $\mathrm{~N}-\mathrm{S}$ & $W$ & Fratura \\
\hline 74,38 & 286 & 72 & $\mathrm{~N}-\mathrm{S}$ & $W$ & Fratura \\
\hline 74,65 & 284 & 76 & $\mathrm{~N}-\mathrm{S}$ & $W$ & Fratura \\
\hline 76,43 & 295 & 75 & NE-SW & NW & Foliação \\
\hline
\end{tabular}

Fraturas com maiores aberturas ou zonas de fraquezas identificadas pelo cáliper. 
Tabela 2 - Dados estruturais do ponto PP-02.

\begin{tabular}{|c|c|c|c|c|c|}
\hline PROF. (m) & AZIMUTE $\left({ }^{\circ}\right)$ & DIP $\left({ }^{\circ}\right)$ & DIREÇÃO & MERGULHO & CLASSIFICAÇÃO \\
\hline 33,73 & 12,67 & 20,41 & E-W & $N$ & Possível Fratura \\
\hline 34,19 & 27,61 & 30,96 & NW-SE & NE & Fratura \\
\hline 35,16 & 239,62 & 35,75 & NW-SE & SW & Fratura \\
\hline 35,31 & 256,29 & 19,8 & $\mathrm{~N}-\mathrm{S}$ & $W$ & Fratura \\
\hline 35,62 & 191,86 & 17,74 & E-W & $S$ & Fratura \\
\hline 36,27 & 347,7 & 9,09 & E-W & $\mathrm{N}$ & Fratura \\
\hline 36,45 & 244,22 & 40,51 & NW-SE & SW & Possível Fratura \\
\hline 36,63 & 353,27 & 46,12 & E-W & $\mathrm{N}$ & Fratura \\
\hline 36,81 & 350,06 & 47,2 & $E-W$ & $\mathrm{~N}$ & Fratura \\
\hline 37,15 & 311,17 & 15,64 & NE-SW & NW & Fratura \\
\hline 37,15 & 339,38 & 64,32 & E-W & $\mathrm{N}$ & Possível Fratura \\
\hline 37,31 & 338,42 & 34,22 & E-W & $N$ & Fratura \\
\hline 37,52 & 315,16 & 55,22 & NE-SW & NW & Fratura \\
\hline 37,65 & 315,39 & 54,46 & NE-SW & NW & Fratura \\
\hline 37,85 & 140,19 & 58,91 & NE-SW & SE & Fratura \\
\hline 38,35 & 289,55 & 48,35 & $\mathrm{~N}-\mathrm{S}$ & $W$ & Possível Fratura \\
\hline 40,4 & 101,78 & 64,78 & $\mathrm{~N}-\mathrm{S}$ & $E$ & Possível Fratura \\
\hline 40,67 & 119,57 & 61,48 & NE-SW & SE & Possível Fratura \\
\hline 41,66 & 4,38 & 44,13 & E-W & $\mathrm{N}$ & Possível Fratura \\
\hline 41,77 & 359,29 & 49,24 & $E-W$ & $\mathrm{~N}$ & Fratura \\
\hline 41,85 & 7,73 & 17,74 & E-W & $\mathrm{N}$ & Fratura \\
\hline 42,08 & 336,71 & 52,85 & NE-SW & NW & Fratura \\
\hline 42,24 & 209,86 & 80,72 & NW-SE & SW & Fratura \\
\hline 42,61 & 200,43 & 81,23 & E-W & $S$ & Possível Fratura \\
\hline 43,04 & 295,81 & 10,36 & NE-SW & NW & Fratura \\
\hline 43,1 & 63,79 & 23,75 & NW-SE & $\mathrm{NE}$ & Fratura \\
\hline 43,71 & 308 & 68,04 & NE-SW & NW & Possível Fratura \\
\hline 43,9 & 308,91 & 68,96 & NE-SW & NW & Fratura \\
\hline 44,15 & 286,43 & 66,32 & $\mathrm{~N}-\mathrm{S}$ & W & Possível Fratura \\
\hline 44,97 & 244,28 & 74,8 & NW-SE & SW & Fratura \\
\hline 45,21 & 240,17 & 65,56 & NW-SE & SW & Fratura \\
\hline 45,33 & 246,7 & 69,25 & NW-SE & SW & Possível Fratura \\
\hline 46,35 & 301 & 66,32 & NE-SW & NW & Possível Fratura \\
\hline 46,7 & 329 & 17,3 & NE-SW & NW & Possível Fratura \\
\hline 46,73 & 256,02 & 73,24 & $\mathrm{~N}-\mathrm{S}$ & $W$ & Possível Fratura \\
\hline 46,96 & 303,4 & 40,7 & NE-SW & NW & Fratura \\
\hline 47,23 & 310 & 30,6 & NE-SW & NW & Fratura \\
\hline 47,23 & 295,43 & 80,22 & NE-SW & NW & Fratura \\
\hline 47,35 & 308 & 36 & NE-SW & NW & Fratura \\
\hline 47,81 & 303 & 21,2 & NE-SW & NW & Possível Fratura \\
\hline
\end{tabular}




\begin{tabular}{|c|c|c|c|c|c|}
\hline PROF. (m) & AZIMUTE $\left({ }^{\circ}\right)$ & DIP $\left({ }^{\circ}\right)$ & DIREÇÃO & MERGULHO & CLASSIFICAÇÃO \\
\hline 48,03 & 277,6 & 81,63 & N-S & W & Possível Fratura \\
\hline 49,08 & 107 & 14,7 & $\mathrm{~N}-\mathrm{S}$ & $E$ & Fratura \\
\hline 49,91 & 328,59 & 28,65 & NE-SW & NW & Possível Fratura \\
\hline 50,72 & 272,83 & 59,53 & $\mathrm{~N}-\mathrm{S}$ & W & Possível Fratura \\
\hline 51,61 & 64 & 29,7 & NW-SE & NE & Possível Fratura \\
\hline 52,01 & 96 & 15,7 & $\mathrm{~N}-\mathrm{S}$ & $E$ & Possível Fratura \\
\hline 52,23 & 309,97 & 49,24 & NE-SW & NW & Possível Fratura \\
\hline 52,48 & 295 & 18 & NE-SW & NW & Possível Fratura \\
\hline 52,82 & 317 & 52,1 & NE-SW & NW & Possível Fratura \\
\hline 54,63 & 298,94 & 51,12 & NE-SW & NW & Fratura \\
\hline 55,83 & 280,73 & 30,96 & $\mathrm{~N}-\mathrm{S}$ & W & Possível Fratura \\
\hline 60,96 & 206,24 & 57,34 & NW-SE & SW & Possível Fratura \\
\hline 61,56 & 156,37 & 74,14 & NE-SW & SE & Possível Fratura \\
\hline 61,68 & 191,57 & 77,89 & $\mathrm{E}-\mathrm{W}$ & $S$ & Fratura \\
\hline 61,95 & 146,7 & 69,25 & NE-SW & SE & Fratura \\
\hline 62,94 & 92,13 & 66,32 & N-S & $E$ & Fratura \\
\hline 64,14 & 325 & 20,4 & NE-SW & NW & Possível Fratura \\
\hline 64,72 & 309,86 & 53,27 & NE-SW & NW & Fratura \\
\hline 64,76 & 331,86 & 37,7 & NE-SW & NW & Fratura \\
\hline 65,56 & 204,58 & 62,97 & NW-SE & SW & Fratura \\
\hline 70,41 & 296 & 81,33 & NE-SW & NW & Possível Fratura \\
\hline 72,67 & 169 & 35,75 & $E-W$ & $S$ & Fratura \\
\hline 72,77 & 138,4 & 32,62 & NE-SW & SE & Fratura \\
\hline 74,72 & 181,6 & 19,8 & $E-W$ & $S$ & Fratura \\
\hline 75,27 & 294,28 & 73,14 & NE-SW & NW & Foliação \\
\hline 77,22 & 263,65 & 19,8 & $\mathrm{~N}-\mathrm{S}$ & W & Fratura \\
\hline 77,32 & 279,37 & 17,74 & $\mathrm{~N}-\mathrm{S}$ & $W$ & Fratura \\
\hline 82,46 & 81,42 & 4,57 & $\mathrm{~N}-\mathrm{S}$ & $E$ & Possível Fratura \\
\hline 83,15 & 282,02 & 52,85 & $\mathrm{~N}-\mathrm{S}$ & $W$ & Possível Fratura \\
\hline 83,93 & 297,88 & 62,97 & NE-SW & NW & Possível Fratura \\
\hline 83,97 & 299,72 & 80,15 & NE-SW & NW & Possível Fratura \\
\hline 84,77 & 305,09 & 82,09 & NE-SW & NW & Possível Fratura \\
\hline 84,78 & 292,16 & 57,1 & $\mathrm{~N}-\mathrm{S}$ & W & Fratura \\
\hline 84,81 & 288,32 & 39,2 & $\mathrm{~N}-\mathrm{S}$ & W & Fratura \\
\hline 84,93 & 299,81 & 30,96 & NE-SW & NW & Possível Fratura \\
\hline 85,49 & 178,57 & 73,43 & E-W & $S$ & Possível Fratura \\
\hline 87,07 & 290 & 73,97 & $\mathrm{~N}-\mathrm{S}$ & $W$ & Possível Fratura \\
\hline 88,16 & 119,57 & 27,47 & NE-SW & SE & Fratura \\
\hline 88,21 & 103,02 & 51,56 & $\mathrm{~N}-\mathrm{S}$ & $E$ & Possível Fratura \\
\hline 88,24 & 281 & 79,11 & $\mathrm{~N}-\mathrm{S}$ & $W$ & Possível Fratura \\
\hline 88.67 & 99,07 & 27,47 & $\mathrm{~N}-\mathrm{S}$ & $E$ & Possível Fratura \\
\hline 88,98 & 292 & 79,8 & N-S & W & Possível Fratura \\
\hline
\end{tabular}




\begin{tabular}{|c|c|c|c|c|c|}
\hline PROF. (m) & AZIMUTE $\left(^{\circ}\right)$ & DIP $\left(^{\circ}\right)$ & DIREÇÃO & MERGULHO & CLASSIFICAÇÃO \\
\hline 89,1 & 293 & 65,56 & NE-SW & NW & Fratura \\
\hline 89,44 & 97,11 & 25,64 & N-S & E & Possível Fratura \\
\hline 89,66 & 65,32 & 29,25 & NW-SE & NE & Fratura \\
\hline
\end{tabular}

Fraturas com maiores aberturas ou zonas de fraquezas identificadas pelo cáliper. 

Tabela 3: Dados estruturais do ponto P5.

\begin{tabular}{|c|c|c|c|c|c|}
\hline PROF. (m) & AZIMUTE $\left({ }^{\circ}\right)$ & DIP $\left({ }^{\circ}\right)$ & DIREÇÃO & MERGULHO & CLASSIFICAÇÃO \\
\hline 45,61 & 319,32 & 83,34 & NE-SW & NW & Possível Fratura \\
\hline 46,21 & 310 & 83,93 & NE-SW & NW & Possível Fratura \\
\hline 48,03 & 354,65 & 55,22 & $E-W$ & $\mathrm{~N}$ & Fratura \\
\hline 49,04 & 37 & 26,3 & NW-SE & $\mathrm{NE}$ & Possível Fratura \\
\hline 49,59 & 345,5 & 40,02 & $E-W$ & $\mathrm{~N}$ & Possível Fratura \\
\hline 49,84 & 348,4 & 37,8 & $E-W$ & $\mathrm{~N}$ & Fratura \\
\hline 50,45 & 1 & 39,6 & $E-W$ & $\mathrm{~N}$ & Fratura \\
\hline 54,38 & 276,73 & 80,25 & $\mathrm{~N}-\mathrm{S}$ & W & Possível Fratura \\
\hline 54,4 & 273,88 & 71,33 & $\mathrm{~N}-\mathrm{S}$ & $W$ & Fratura \\
\hline 55,17 & 286,98 & 54,07 & $\mathrm{~N}-\mathrm{S}$ & W & Fratura \\
\hline 55,2 & 283,13 & 72,65 & $\mathrm{~N}-\mathrm{S}$ & W & Fratura \\
\hline 56,47 & 287 & 64,75 & $\mathrm{~N}-\mathrm{S}$ & $W$ & Fratura \\
\hline 56,85 & 257 & 65,16 & $\mathrm{~N}-\mathrm{S}$ & W & Fratura \\
\hline 57,07 & 282 & 49,5 & $\mathrm{~N}-\mathrm{S}$ & W & Fratura \\
\hline 57,17 & 284,95 & 57,47 & $\mathrm{~N}-\mathrm{S}$ & $W$ & Possível Fratura \\
\hline 57,29 & 313,82 & 31,59 & NE-SW & NW & Possível Fratura \\
\hline 57,52 & 298,44 & 35,75 & NE-SW & NW & Possível Fratura \\
\hline 58,46 & 286,31 & 57,34 & $\mathrm{~N}-\mathrm{S}$ & $W$ & Possível Fratura \\
\hline 58,79 & 259,53 & 59,83 & $\mathrm{~N}-\mathrm{S}$ & W & Possível Fratura \\
\hline 60,17 & 281,85 & 45,57 & $\mathrm{~N}-\mathrm{S}$ & $W$ & Possível Fratura \\
\hline 61,21 & 330 & 9,9 & NE-SW & NW & Possível Fratura \\
\hline 61,66 & 281,85 & 66,32 & $\mathrm{~N}-\mathrm{S}$ & $\mathrm{W}$ & Fratura \\
\hline 61,79 & 229,97 & 48,24 & NW-SE & SW & Fratura \\
\hline 62,09 & 240,85 & 61,74 & NW-SE & SW & Possível Fratura \\
\hline 62,55 & 260,81 & 70,35 & $\mathrm{~N}-\mathrm{S}$ & W & Fratura \\
\hline 63,96 & 266,48 & 70,85 & $\mathrm{~N}-\mathrm{S}$ & $W$ & Possível Fratura \\
\hline 64,44 & 268 & 51,12 & $\mathrm{~N}-\mathrm{S}$ & W & Fratura \\
\hline 64,77 & 214,31 & 55,95 & NW-SE & SW & Fratura \\
\hline 67,39 & 256,59 & 82,69 & $\mathrm{~N}-\mathrm{S}$ & W & Possível Fratura \\
\hline 67,47 & 243 & 36,5 & NW-SE & SW & Possível Fratura \\
\hline 68,28 & 228,28 & 79,51 & NW-SE & SW & Fratura \\
\hline 69,03 & 261,35 & 81,44 & $\mathrm{~N}-\mathrm{S}$ & $W$ & Fratura \\
\hline 69,85 & 254,95 & 75,9 & $\mathrm{~N}-\mathrm{S}$ & $W$ & Foliação \\
\hline 70,06 & 256 & 73,24 & $\mathrm{~N}-\mathrm{S}$ & $W$ & Foliação \\
\hline 70,27 & 262,65 & 77,52 & $\mathrm{~N}-\mathrm{S}$ & W & Foliação \\
\hline 71,12 & 117,94 & 66,68 & NE-SW & SE & Possível Fratura \\
\hline 75,28 & 168,51 & 77,31 & NE-SW & SE & Possível Fratura \\
\hline 76,73 & 178 & 70,35 & $\mathrm{~N}-\mathrm{S}$ & $S$ & Fratura \\
\hline 79,66 & 252,06 & 38,66 & $\mathrm{~N}-\mathrm{S}$ & W & Fratura \\
\hline 79,99 & 248,08 & 34,22 & $\mathrm{~N}-\mathrm{S}$ & $\mathrm{W}$ & Possível Fratura \\
\hline
\end{tabular}

Fraturas com maiores aberturas ou zonas de fraquezas identificadas pelo cáliper. 
ANEXO 3 - Espaçamento dos grupos de fraturas 


\section{PP-01}

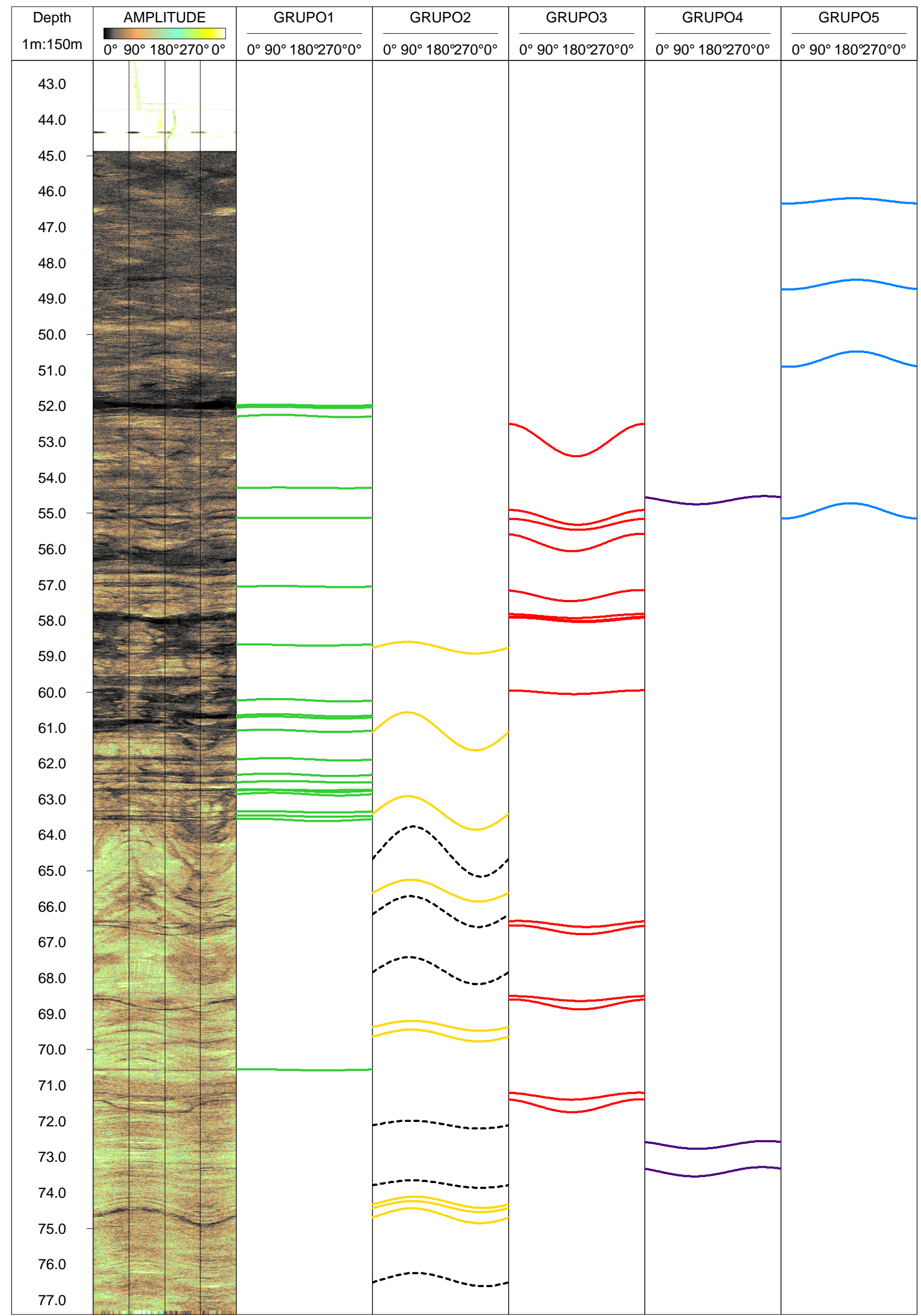



P5

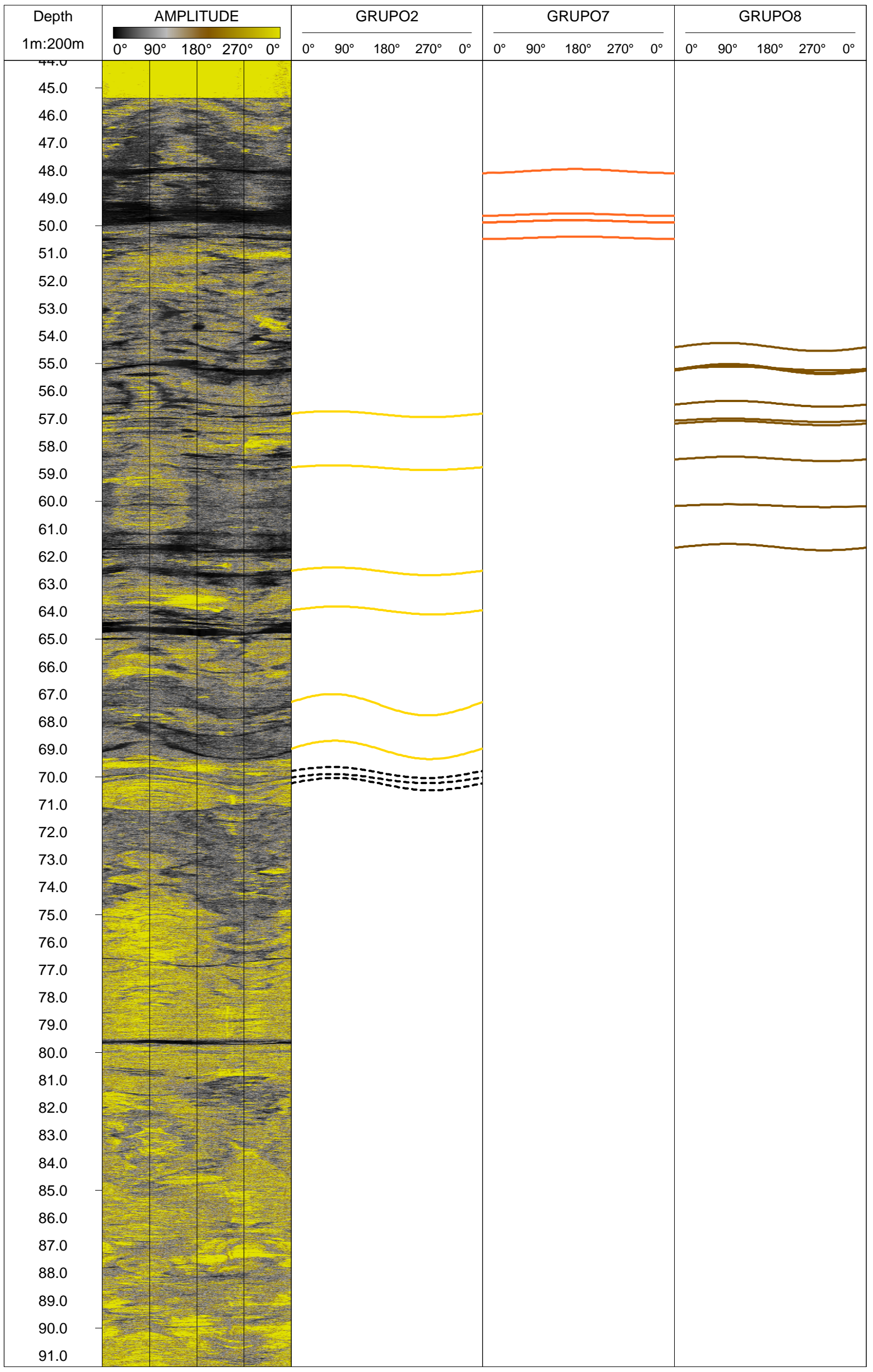

